\title{
Colonisation and Aboriginal Land Tenure: Taiwan during the Qing Period (1684-1895) and the Japanese Period (1895-1945)
}

\author{
Ruiping YE
}

\author{
A thesis \\ Submitted to the Victoria University of Wellington \\ In fulfilment of the requirements for the degree of Doctor of Philosophy
}

Faculty of Law

Victoria University of Wellington 



\begin{abstract}
This thesis is concerned with the land rights of the aboriginal peoples of Taiwan. It explores how under the Qing (1684-1895) and Japanese (1895-1945) regimes, laws and policies regarding aboriginal land in Taiwan resulted in aboriginal land tenure changes and loss of land. The thesis also explores how the respective legal systems and legal cultures of the Qing and Japanese states influenced policy-making concerning aboriginal land.

The thesis examines the different effects of the Qing and Japanese administrations on aboriginal land tenure in Taiwan. It analyses Qing policies towards land settlement in Taiwan, the extent of the government's recognition and protection of aboriginal land rights, the changes that the distinctive Qing property law regime, including the Chinese customary land practice, brought to aboriginal land tenure, and the aborigines' interaction with the government and settlers regarding their land. To a lesser extent and as a comparison, the thesis then discusses the Japanese government's attitudes towards the aborigines and aboriginal land tenure, and Japan's reforms of land tenure in Taiwan.

The thesis puts the study of Taiwan aboriginal land policies into the wider framework of the administration of Taiwan by two governments whose legal systems were quite different: the Qing government, which in many respects was a traditional Chinese imperial regime, and Japan, which by the time it colonised Taiwan had reformed its law along European lines and which was considered to be a modern and European-style state. Ultimately, this thesis attempts to find out what role the Qing legal system played in shaping the policies and in the transformation of aboriginal land tenure, and how the Japanese legal system, largely westernised after the Meiji Restoration in 1868, influenced Japanese policies regarding aboriginal land in Taiwan. Thus a central concern of the thesis is the connection between law and colonial policy.

This thesis concludes that the Qing colonisation of Taiwan was different from the later Japanese colonisation of Taiwan and from Western styles of colonisation. Shaped by its legal culture, constitutional framework, administrative system and property law regime, the Qing government had very little or no intention and took little action to transform aboriginal land tenure. Rather the Qing legal tradition allowed for or enabled Chinese settlers to manipulate aboriginal land tenure and impose Chinese culture on the aborigines, an effect often unintended by the government. In contrast, Japan colonised Taiwan with a specific intention to exploit the resources of the island and thus the government played a strong role in changing aboriginal land tenure in Taiwan.
\end{abstract}

Key words: Taiwan, Aboriginal land tenure, Colonisation, Legal history, Qing, Japan 


\section{Notes on style, transliteration and translation}

This thesis follows the New Zealand Law Style Guide. Where a Chinese language source is cited, the translation of the title is included in square brackets. However if the English language title is provided by the author or the publisher, it is shown in round brackets with quotation marks (for articles and book chapters) or in italics (books).

All primary sources quoted are translated by the author of this thesis unless otherwise stated. The Chinese terms and names in the text are rendered in Pinyin, unless an author's preferred spelling of name is known, or a place name has an established English spelling (for example, Taipei).

Official titles follow Charles O Hucker A Dictionary of Official Titles in Imperial China (Stanford University Press, Stanford, 1985) unless otherwise stated. 


\section{Acknowledgements}

Many people have helped me throughout this journey, and it is with deep gratitude that I acknowledge their help.

First I thank my Victoria supervisors Professor Richard Boast QC and Professor Tony Angelo ONZM, and Professor Duncan Campbell, then Curator and Director of the Center for East Asian Garden Studies at the Huntington Library.

Professor Boast instigated the project as a case study to his research on the tenurial changes in the Pacific Rim in the $19^{\text {th }}$ century, chose me to do it, funded my study with part of his Royal Society of New Zealand's Marsden grant, and guided me through to the completion of the thesis. Without him I would not have the thesis in front of me today.

Professor Angelo challenged me in my thinking and arguments, and tirelessly read and critiqued my numerous drafts. He has guided me and nurtured me, putting in efforts way beyond what is required of a supervisor.

Professor Campbell, as my Chinese studies advisor, has introduced me to a wealth of literature, read my drafts carefully and provided much helpful feedback.

I am very fortunate to be guided by three of the greatest teachers, each in a different field, who have held back nothing from helping me to grow and to complete the journey.

I am grateful to the supporting system within the University. The postgraduate administrator, the libraries, the Law School and the Faculty of Graduate Research have provided what I needed for the research and helped to ensure the process run smoothly. I wish to especially thank the interloan team at the University library. They have sourced many books, articles and theses from both New Zealand and overseas, which were critical to the study and were otherwise beyond my reach.

Outside of the University, Professors Hsieh Kuo-hsing and Liu Shi-yung of the Taiwan Institute of History, Academic Sinica, have very kindly accommodated me and assisted me with library resources on my visit. I benefited from discussions with Professor Ka Chihming and Professor Wang Tay-sheng at the early stage of my research. The National Central Library of Taiwan, the National Library of Australia, the Australian National University Menzies library, the Harvard Yen-ching Library and the US Library of Congress have all opened their doors, and some even extended helpful hands in my efforts to collect primary and secondary sources. The Center for GIS, RCHSS, Academia Sinica and Professor Ka Chih-ming have kindly permitted the use in this thesis of a number of maps that they created. 
Additional funding supports have facilitated field research and are gratefully acknowledged. The Postgraduate Students Association awarded the Postgraduate Research Excellence Award, which helped to fund my first trip to Academia Sinica (Taipei) and the Taiwan Research Institute (Xiamen). The Australian Centre on China in the World granted a Library Fellowship for research at the Australian National Library and the Australian National University. The Universities New Zealand awarded a Claude McCarthy Fellowship which supported conference attendance and further research at Canberra. The Center for Chinese Studies of Taiwan's Research Grant for Foreign Scholars in Chinese Studies facilitated and financed further research at the National Central Library of Taiwan. Attendance of international conferences was also supported by the University's research grant, the Australian and New Zealand Law and History Society Bruce Kercher Scholarship, and the North America Taiwan Studies Association annual conference travel grant.

I thank conference organisers for giving me the opportunities to present the early findings of my research, and other conference attendees for providing helpful feedback and discussions. The research journey was accompanied by fellow postgraduate students where mutual encouragement and supports were extended. Friends have encouraged me in various ways, and I am particularly thankful to Dr Pauline Keating and Judge Margaret Lee. I am also indebted to my employer, Chief Executive of the Council of Legal Education, Rosemary Gordon MNZM, for a flexible work arrangement and the moral support.

My gratitude is extended to my examiners, Professor John Shepherd, Professor Brian Moloughney and Dr Carwyn Jones for taking the time to read my thesis and providing very constructive reports.

My family has given me tremendous support in the past three years. My husband Shu had to take on a lot more family responsibilities, and my girls, Weichu and Yusi, have had a lot less time with their mother. They have all encouraged me and have been gracious to me. Special mention goes to Yusi, who as a year six student when I started the study, advised me that I must find my research question first (school does teach them things!), and maintained an ongoing interest as to whether I have found a thesis for the study. My family's love and support have sustained me.

Last, and most, of all, I thank the one who has placed "a lamp unto my feet and a light unto my path".

Ruiping Ye

February 2017 


\section{Contents}

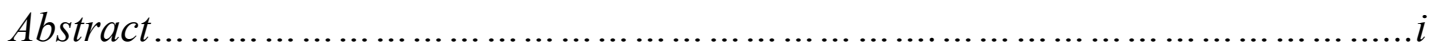

Notes on style, transliteration and translation ............................................ii

Acknowledgements ......................................................................

List of Regnal Names and Years............................................................. vii

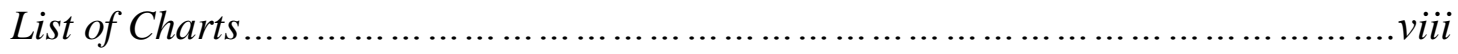

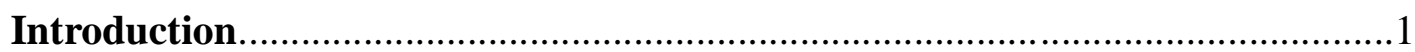

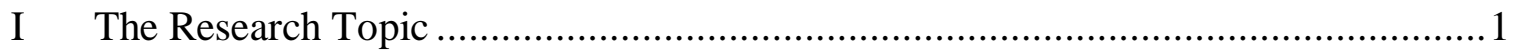

II Theoretical Framework and Literature Review................................................4

III Resource, Methodology and Thesis Structure....................................................12

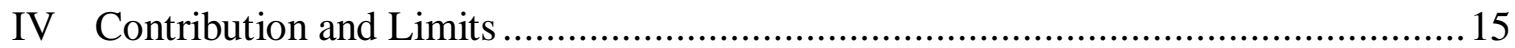

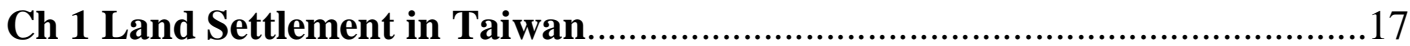

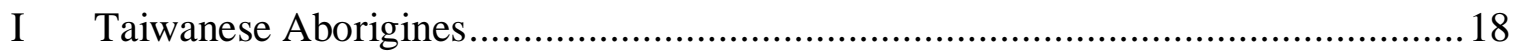

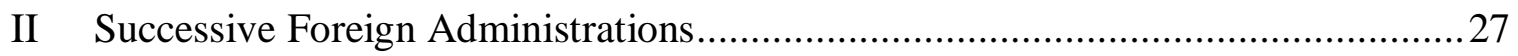

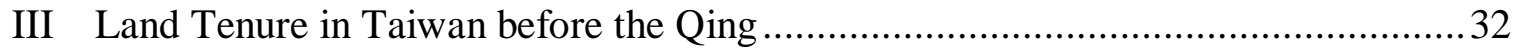

IV Land Settlement during the Qing Period ................................................................39

V Land Settlement Pattern and Acculturation of Aborigines .......................................4

Ch 2 Qing Settlement Policies in Taiwan.............................................................49

I Qing Administrative and Legal Systems ............................................................50

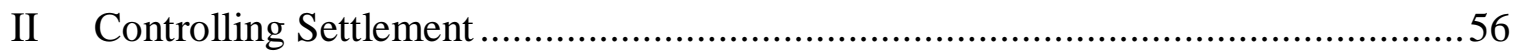

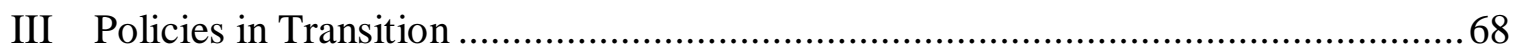

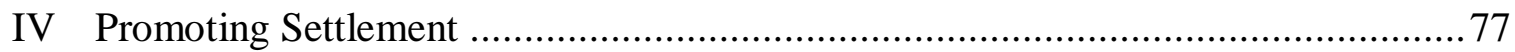

V Qing Tradition and the Formation of Policy on Taiwan........................................85

Ch 3 Recognition and Protection of Aboriginal Land Holdings..........................89

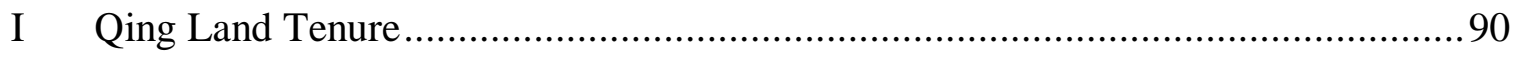

II Aboriginal Land: an Emerging Concept ………….............................................95

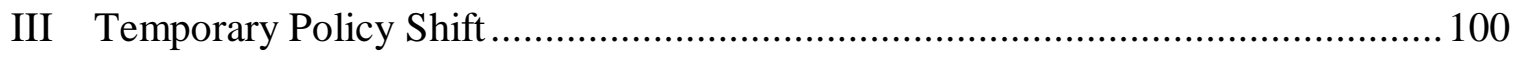

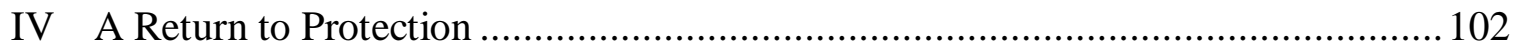

V The Government Becomes Proactive …………................................................. 115 
VI After 1875

VII The Effects of Legal Tradition

Ch 4 The Influence of Chinese Customary Land Tenure

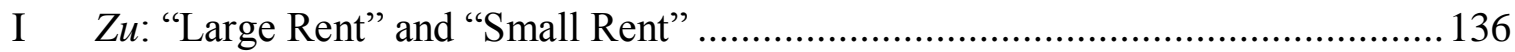

II Aboriginal Land Transactions .................................................................... 149

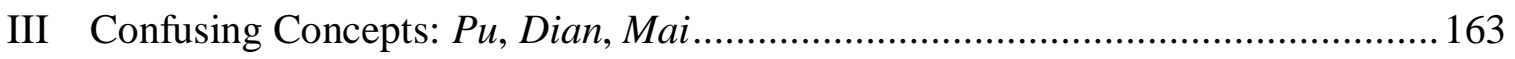

IV Property Law Regime and Aboriginal Land Tenure .................................... 172

Ch 5 Aboriginal Reactions and Further Government Responses................175

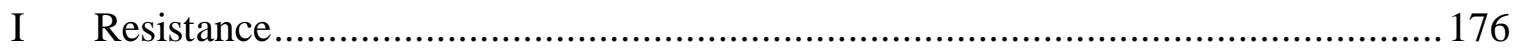

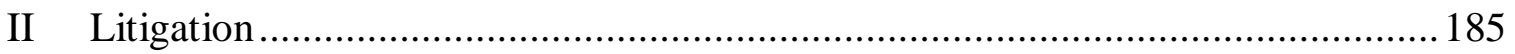

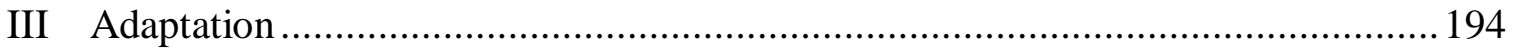

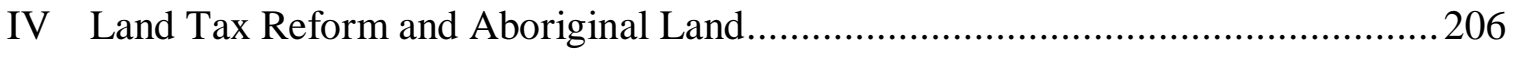

V Three Actors...................................................................................... 213

Ch 6 Aboriginal Land Tenure under the Japanese Colonisation................215

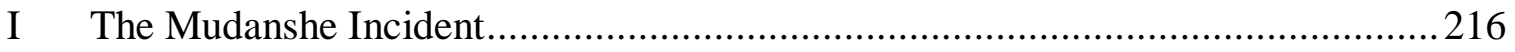

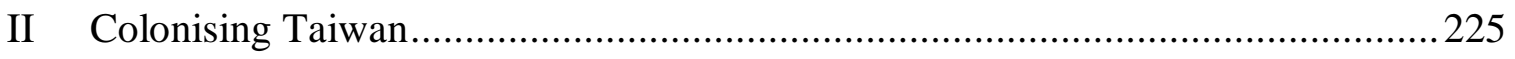

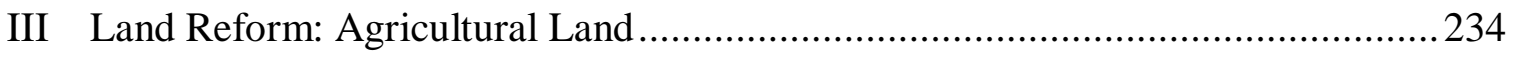

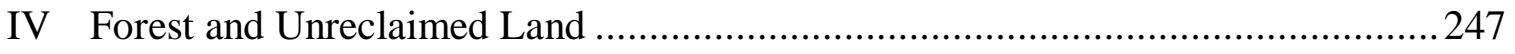

V Pseudo-European Colonisation ....................................................... 253

Conclusion: Land Tenure, Colonisation, and Legal Tradition...................257

I Transformation of Land Tenure and Aboriginal Society .................................257

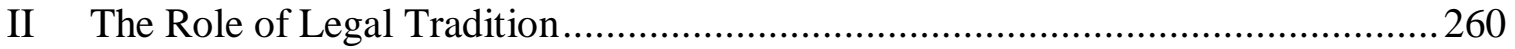

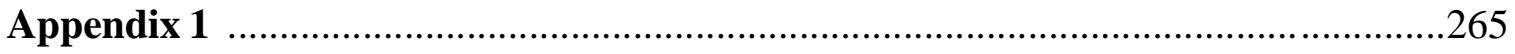

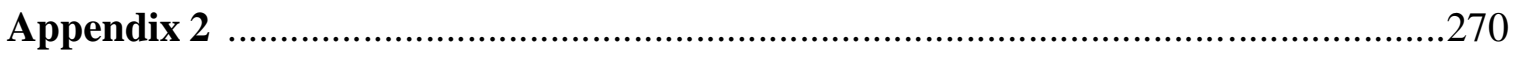

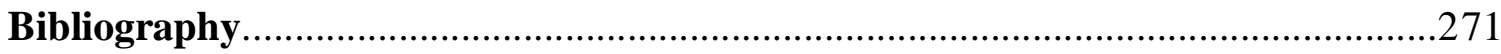




\section{List of Regnal Names and Years}

Qing Dynasty (1636-1912)

$\begin{array}{ll}\text { Chongde } & 1636-1643 \\ \text { Shunzhi } & 1644-1661 \text { (entered Beijing in 1644) } \\ \text { Kangxi } & 1662-1722 \text { (annexed Taiwan in 1684) } \\ \text { Yongzheng } & 1723-1735 \\ \text { Qianlong } & 1736-1795 \\ \text { Jiaqing } & 1796-1820 \\ \text { Daoguang } & 1821-1850 \\ \text { Xianfeng } & 1851-1861 \\ \text { Tongzhi } & 1862-1874 \\ \text { Guangxu } & 1875-1908 \text { (ceded Taiwan to Japan in 1895) } \\ \text { Xuantong } & 1909-1912\end{array}$

Selected Japanese Reigns

$\begin{array}{ll}\text { Meiji } & 1867-1912 \text { (annexed Taiwan in 1895) } \\ \text { Taishō } & 1912-1926 \\ \text { Shōwa } & 1926-1989 \text { (relinquished Taiwan in 1945) }\end{array}$

When the years are indicated in regnal years, it is shown by the regnal title followed by the year of reign. For example, Kangxi 23 means the $23^{\text {rd }}$ year of the Kangxi reign.

\section{Measurements}

\begin{tabular}{|c|c|}
\hline Distance: & $1 l i$ 里 $\approx 0.576 \mathrm{~km}$ \\
\hline Area: & $\begin{aligned} 1 \text { jia } \text { 甲 } & \approx 0.97 \text { hectares } \\
& \sim 11 \text { 新 }\end{aligned}$ \\
\hline & $\begin{array}{l}\approx 11 \mathrm{mu} \text { 嘼 } \\
1 \text { qing 頃 }=100 \mathrm{mu} \\
1 \mathrm{mu} \approx 666.67 \mathrm{~m}^{2}\end{array}$ \\
\hline
\end{tabular}

Capacity: $\quad 1$ shi 石 $\approx 103.6$ litres 


\section{List of Charts}

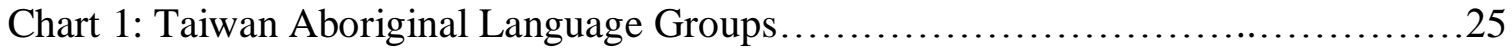

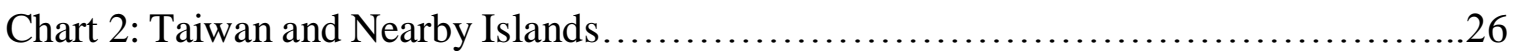

Chart 3: Aboriginal Groups Recognised by the Current Taiwan Government.............27

Chart 4: Land Settlement during the Dutch, the Zheng and the Qing Periods..............45

Chart 5: Settlement Areas and Direction.................................................46

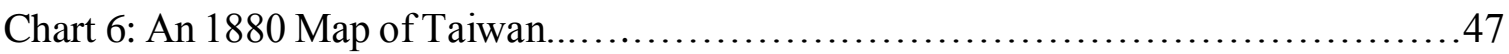

Chart 7: Administrative Control during the Kangxi and Yongzheng Reigns.................59

Chart 8: Imperial Regulations Concerning Migration to Taiwan..........................64

Chart 9: Imperial Regulations Concerning Aboriginal Territories...............................66

Chart 10: Aboriginal Boundaries during the Kangxi and Qianlong Reigns ...................66

Chart 11: Administrative Area during the Jiaqing Reign................................72

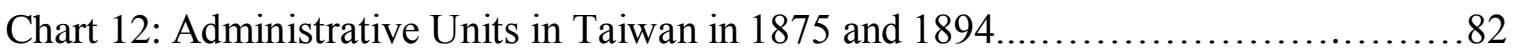

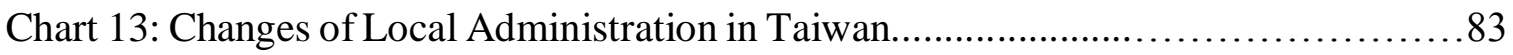

Chart 14: Laws/Policies Protective of Aboriginal Land Rights (1684-1795)................106

Chart 15: Main Points of the Land Policies of the Qianlong Government................107

Chart 16: Three-tier Land Rights System...............................................146

Chart 17: Key Terms of Aboriginal-Settler "Tenancy" Deeds...........................169

Chart 18: Key Terms of Anli Village "Land for Water" Agreements......................198 


\section{Introduction}

This introductory chapter defines the research topic, considers the theoretical framework of the thesis, reviews relevant literature to place the thesis in the context of current literature, outlines the resources, methodology and the structure of the thesis, and notes the contribution and limits of this thesis.

\section{The Research Topic}

This thesis is concerned with the land rights of the aboriginal peoples of Taiwan. More specifically, this thesis explores how, under the Qing (1684-1895) and the Japanese (18951945) regimes, government laws and policies regarding aboriginal land resulted in land tenure changes and loss of land by Taiwanese aborigines, and how the respective legal cultures and systems of Qing and Japan influenced their approaches towards aboriginal land.

\section{A The Background}

Ethnically distinct from the majority Chinese population, presently Taiwan's aborigines make up about $2.3 \%$ of the total population. ${ }^{1}$ Once occupying and controlling all land in Taiwan, Taiwan's aborigines lost almost all of their land through settlement and colonisation, and aboriginal land tenure was completely transformed. Some of the aboriginal groups have disappeared as distinctive aboriginal groups through acculturation, while the remaining groups live on aboriginal reserves (yuanzhumin baoliudi 原住民保留 地). As at 2001, aboriginal reserves measured 251,080 hectares, but the aborigines actually used only about half of the reserves. The other half were either located in remote, rocky or reservoir areas and could not be used, or were used by the government, businesses or nonaborigines. ${ }^{2}$ After several "return my land” (huan wo tudi 還我土地) movements in the 1980s and 1990s, the government established a mechanism to grant aborigines ownership

\footnotetext{
${ }^{1}$ Total indigenous population is about 540,000 as of December 2014. See The Republic of China Yearbook 2015 (Executive Yuan, Taipei, 2015), at 49.

${ }^{2}$ Lin Shu-Ya "Jie/chonggou Taiwan yuanzhu minzu tudi zhengce" ("De-/Reconstructing the Land Policies for Indigenous Peoples in Taiwan”) (PhD diss, NTU, 2007), at 84 and 110.
} 
over reserved land if certain conditions are met. However the percentage of aboriginal ownership remains small. ${ }^{3}$

During the Qing period some aboriginal groups, mostly those that lived in the plains areas, were acculturated and lost their distinctive features as aborigines, and also possession and control of their land. By the end of the Qing period, the western plains of Taiwan were fully developed as farmland, and were occupied by Chinese settlers, whose population amounted to 3.7 million and were the majority of the total population. ${ }^{4}$ Having taken over Taiwan from the Qing in 1895, the Japanese administration dealt with the aboriginal groups that were still recognisable as aborigines, deprived them of their land and established aboriginal reserves. The current system of aboriginal reserves is a legacy of the Japanese colonial arrangement. The current Taiwan government inherited that system and has only recently started to make slight changes as a result of aboriginal rights movements. ${ }^{5}$

A notable difference between the Qing and the Japanese administrations was the speed of land tenure changes. When the Qing ceded Taiwan to Japan after its two-century rule, the aborigines still occupied and controlled two-thirds of the island. ${ }^{6}$ In contrast, fifty years of Japanese colonial rule saw most aborigines displaced and confined to small areas of aboriginal reserves, which they did not own, and which measured about one-eighth of their ancestral land. ${ }^{7}$ Land loss of the aborigines during the Qing period was a gradual process, at a speed much slower than that during the Japanese period, and also slower than that in European colonies. ${ }^{8}$ There was no conscious deprivation by the government.

\footnotetext{
${ }^{3}$ As at 2001, aborigines had ownership of 50,435 hectares of reserved land, about $20 \%$ of the total reserves. See ibid, at 110 and 136.

${ }^{4}$ Chuang Chi-fa "Qingdai Taiwan tudi kaifa yu zuqun chongtu" [Land reclamation and ethnic conflicts in Qing Taiwan] (2000) 36 Taiwan shiji 3, at 27.

${ }^{5}$ Lin, above $\mathrm{n} 2$, at 91-101.

${ }^{6}$ Yosaburō Takekoshi (trans George Braithwaite) Japanese Rule in Formosa (Longmans, Green and Co, London, 1907), at 218.

${ }^{7}$ Lin Chiou-mien "Taiwan geshiqi tudi zhengce yanbian jiqi yingxiang zhi tantao" [The evolution and influence of aboriginal land policies of different periods in Taiwan] (2001) 2 Taiwan tudi yanjiu 23, at 32.

${ }^{8}$ For example, two-thirds of the Maori land in New Zealand was alienated in the first 20 years after the British colonisation. See Richard Boast Buying the Land, Selling the Land: Governments and Maori Land in the North Island1865-1921 (Victoria University Press, Wellington, 2008), at 26. In Australia, the continent was seen as terra nullius and the aborigines were deprived of their land upon European settlement. See Stuart
} 


\section{B The Topic}

This thesis studies why the Qing administration had different effects on Taiwan aboriginal land tenure from that under Japanese administration, and seeks the answer from the legal point of view, that is, from the perspective of Qing legal system - its legal culture, administrative system and decision-making process, and its property law regime. For example, what were the Qing policies concerning expansion to and administration of Taiwan? Was there a consistent policy rationale and if there was, what was the rationale? How did the Qing view the aborigines and their land rights, compared with the Japanese view of the colonised peoples and their land rights? How did the respective property law concepts and practice of Qing and Japan affect the aboriginal land tenure changes in Taiwan?

A few terms need to be defined at the outset. In this thesis,

- Taiwan refers to the island of Taiwan, and does not include other islands or archipelagos under the jurisdiction of the Taiwan government.

- Plains aborigines refer to those who lived on the plains areas. They were exposed to the Chinese culture when Han Chinese settlement spread, and became acculturated during the Qing period. Therefore they are sometimes referred to as acculturated aborigines.

- Mountain aborigines refer to those who lived in the mountain areas and maintained their culture until after the Japanese occupation. Mountain aborigines are also referred to as non-acculturated aborigines.

- Land reclamation (kaiken 開墾; tuoken 拓墾) means to develop non-agricultural land into agricultural land, to bring land into production, as agriculture was the single most important way of land use in traditional Chinese culture. A person who reclaimed land is referred to as a reclaimer.

Banner Possessing the Pacific: Land, Settlers, and Indigenous People from Australia to Alaska (Harvard University Press, Cambridge (Mass), 2007), ch 1. 


\section{Theoretical Framework and Literature Review}

\section{A Expansion, Colonisation and Colonialism}

When surveying the legal traditions of the world, Patrick Glenn raised the question of the role of law in Western expansion. ${ }^{9}$ Glenn also observed that the Chinese legal tradition, rooted in Confucianism and supplemented by Taoism and Buddhism, did not favour expansion and therefore "the world has never seen a form of east Asian expansion similar to that of Europe". ${ }^{10}$

The view that China did not expand, or did not expand as European countries did, would have been opposed by some scholars who study the history of the Qing Dynasty. In recent decades Qing history scholars have challenged the traditional view that colonialism was largely associated with European countries, and have asserted that the Qing was a "colonial empire". ${ }^{11}$ These scholars argued that similar to the European states, the Qing Empire was engaged in "imperial conquest, migration of people, and cultural and commercial exchange", 12 and that the Qing colonialism was "similar to, and partially contemporary with, that of Europe". ${ }^{13}$ More specifically, one scholar has argued that the Qing administration in Taiwan was a variety of colonialism, ${ }^{14}$ a view that has been accepted by some scholars, ${ }^{15}$ although scholars specialising in the history of colonialism tend not to regard the Qing rule of Taiwan as colonial. ${ }^{16}$

\footnotetext{
${ }^{9}$ H Patrick Glenn Legal Traditions of the World: Sustainable Diversity in Law (5ed, Oxford University Press, Oxford, 2014), at 272-279.

${ }^{10}$ At 355.

11 For example, Michael Adas "Imperialism and Colonialism in Comparative Perspective" (1998) 20 International History Review 371-388; Nicola Di Cosmo "Qing Colonial Administration in Inner Asia" (1998) 20 International History Review 287-309; Peter C Perdue "Comparing Empires: Manchu Colonialism" (1998) 20 International History Review 255-262.

12 Perdue, ibid, at 256.

${ }^{13}$ Laura Hostetler Qing Colonial Enterprise: Ethnography and Cartography in Early Modern China (University of Chicago Press, Chicago, 2001), at 25.

${ }^{14}$ Emma Jinhua Teng Taiwan's Imagined Geography: Chinese colonial travel writing and pictures, $1683-$ 1895 (Harvard University Asia Centre, Cambridge (Mass), 2004), at 8-9.

${ }^{15}$ For example, Robert Eskildsen "Taiwan: A Periphery in Search of a Narrative" (2005) 64 Journal of Asian Studies 281, at 287 and 290.

${ }^{16}$ For example, Jürgen Osterhammel (trans Shelley L Frisch) Colonialism: A Theoretical Overview (Markus Wiener Publishers, Princeton, 1997), at 42, notes that Taiwan was “uncolonised” by the Qing.
} 
The different views about Qing colonialism and the Qing colonial rule in Taiwan are to some extent related to the different interpretations scholars attribute to the terms "colonial" and "colonialism". 17 The Qing colonial scholars have rarely defined "colonial" and "colonialism", but the implication is that the expansion of territories and the subjugation of peoples of different cultures or ethnicities constituted colonialism. One scholar noted that China was "the metropole for colonial initiatives that span centuries and numerous, diverse cultures across a great swath of Central, East, and South-East Asia". ${ }^{18}$ Another pointed out that the Qing was a "colonial empire that ruled over a diverse collection of peoples with separate identities". ${ }^{19}$ One scholar employed Edward Said's definition that colonialism is "the implanting of settlements on distant territory" to support the argument of Qing colonialism in Taiwan. ${ }^{20}$

While the terms are capable of narrow or wide interpretation, where the interpretation differs, the substance of the term which one person describes will be different from that described by another person. The above arguments about Qing colonialism have adopted a relatively wide interpretation of the term colonialism, and at times seem to have equated the terms colonisation and colonialism, which are closely related but not always identical. ${ }^{21}$

Colonisation is an activity of human society which denotes "a process of territorial acquisition". ${ }^{22}$ The Qing acquired Taiwan in 1684. Chinese settlement in Taiwan increased steadily in the subsequent centuries. For most of the time the Qing government tried to contain settlement, rather than to implant settlement. However, the advance of Chinese settlement often resulted in the expansion of Qing jurisdiction. Therefore arguably Qing possession of Taiwan was a form of colonisation.

\footnotetext{
17 The ambiguity of terms relating to colonisation and colonialism is often commented on, for example, see Osterhammel, ibid, at 4; Robert Aldrich and John Connell The Last Colonies (Cambridge University Press, Cambridge, 1998), at 3.

18 Adas, above n 11, at 371 .

${ }^{19}$ Perdue, above $\mathrm{n} 11$, at 255.

20 Teng, above n 14, at 8, quoting Edward Said Culture and Imperialism (Random House, New York, 1994), at 9 .

${ }^{21}$ For a discussion of these terms, see Osterhammel, above n 16, especially ch 1 and 2.

${ }^{22}$ At 4. Emphasis original.
} 
Different from colonisation, colonialism is "a system of domination", domination of "people of another culture". ${ }^{23}$ There are three qualifications for such a domination to be colonialism - the external manipulation and transformation of the indigenous society "according to the needs and interests of the colonial rulers"; the dissimilarity between the colonisers and colonised; and the assumption that the colonisers' culture is superior to that of the colonised which led to the imposition of the colonisers' culture on the colonised. ${ }^{24}$ The Qing rulers were Manchus and Taiwan's aborigines were Austronesians, there is no question that the rulers and the ruled were dissimilar. Generally the Manchu rulers and the Chinese officials assumed that the Manchu and Chinese cultures were superior to that of the aborigines, as evidenced in some of the official documents and private writings of the Qing period, although at times the aborigines' culture was praised for its antiquity and innocence. ${ }^{25}$ It is also arguable that Qing rulers acquired and administered Taiwan according to their own needs and interests. Therefore, Qing domination of the Taiwanese aborigines satisfied the conditions of dissimilarity in culture, assumption of superiority, and self-interest.

What remain in question are the presence, intention, method and extent of the external manipulation and transformation of the aboriginal society and the imposition of Manchu or Chinese culture on the aborigines by the Qing government. These are the keys to deciding the nature of Qing colonisation of Taiwan. This thesis examines the nature of Qing colonisation of Taiwan through analysing Qing policies towards land settlement and aboriginal land rights in Taiwan. Aboriginal land issues have today been the cause of most of the grievances of the colonised. They most fully evidenced the colonisers' domination of the colonised, not only for the Taiwanese aborigines, but generally for all indigenous peoples.

The process and system of Japanese colonisation of Taiwan is set as a comparison to that of the Qing colonisation. Scholars have more readily accepted that Japanese overseas expansion and its administration of Taiwan was colonialism than they have done of Qing

\footnotetext{
${ }^{23}$ At 4 and 15. Emphasis original.

24 At 15-16.

${ }^{25}$ See Teng, above n 14, in general, but at 14 and 79 in particular.
} 
expansion and administration of Taiwan. ${ }^{26}$ This implies that there existed fundamental differences between Qing colonisation and Japanese colonisation of Taiwan. In fact it has been observed that: ${ }^{27}$

[s]ince Japanese imperialism emulated but also stood apart from Western imperialism, the difference between Japanese and Qing colonial rule in Taiwan might be seen partly as differences within Asian colonialisms and partly as differences between Asian and Western colonialism.

One task of this thesis is to explore the different colonisation and expansion style of the Qing from that of Japan, in the particular area of aboriginal land tenure, and to suggest the reasons for the differences from the perspective of legal traditions and systems.

The subject matter is slightly complicated by the fact that the Qing rulers were Manchus, not Chinese. Using the Manchu language archives, recent scholarship has discovered aspects of the Qing ruling house which had not been revealed in the Chinese language archives of the Qing. Known as the "new Qing history" school, the scholars stressed the Manchu characteristics and identity of the Qing ruling house. They challenge the traditional view that the Qing were sinicised, a view maintained by the "sinicisation" school of scholars. ${ }^{28}$ Despite the heated debate and the important differences between these two schools, in effect the findings of the new Qing history school reveal the multi-dimensional characteristics of the Qing ruling house, but do not deny the sinicisation of the Qing as such. That is to say, in some aspects and at some levels the Qing Court was sinicised, while

\footnotetext{
${ }^{26}$ For example, see Osterhammel, above n 16, at 79. For Japanese colonial empire in general, and Japanese colonial rule in Taiwan in particular, see Ramon H Myers and Mark R Peattie (eds) The Japanese Colonial Empire, 1895-1945 (Princeton University Press, Princeton, 1984); Hyman Kublin "The Evolution of Japanese Colonialism" (1959) 2 Comparative Studies in Society and History 67-84; Liao Ping-hui and David Der-wei Wang (eds) Taiwan under Japanese Colonial Rule, 1895-1945 (Columbia University Press, New York, 2006).

${ }^{27}$ Eskildsen, above n 15, at 290.

${ }^{28}$ For the Qing's retention of its Manchu heritage and identity, see Mark C Elliott The Manchu Way: The eight banners and ethnic identity in late imperial China (Stanford University Press, Stanford, 2001); Evelyn S Rawski "Reenvisioning the Qing: The Significance of the Qing Period in Chinese History" (1996) 55 Journal of Asian Studies 829-850; Pamela Kyle Crossley "Thinking about Ethnicity in Early Modern China" (1990) 11 Late Imperial China 1-35. For scholarship on the Qing's sinicisation, see, in particular, Ping-ti Ho "In Defence of Sinicization: A Rebuttal of Evelyn Rawski's 'Reenvisioning the Qing"” (1998) 57 Journal of Asian Studies 123-155; Pei Huang Reorienting the Manchus: A Study of Sinicization, 1583-1795 (Cornell University, Ithaca, New York, 2011).
} 
at others it maintained, utilised and stressed its Manchu way. ${ }^{29}$ In particular, it is generally accepted that the Qing administrative institutions and legal system were mainly inherited from the previous Ming Dynasty and were largely Chinese. ${ }^{30}$ Therefore in this thesis the examination of the Qing legal system will in most aspects turn on discussion of the Chinese legal system, but where the system had unique Qing characteristics this will be made clear.

\section{$B$ Aboriginal Land Tenure in Taiwan during the Qing and Japanese Periods}

While scholars supporting the colonial nature of the Qing administration in Taiwan have not examined it from the angle of aboriginal land issues, scholars who study aboriginal land issues in Qing Taiwan have not usually looked at the issues through the lens of colonisation or colonialism. Studies of Japanese colonialism and Japanese aboriginal land policies have also often been separate.

At the turn of the $20^{\text {th }}$ century, the Japanese anthropologist Inō Kanori pioneered the research on Taiwan's aborigines, Chinese land settlement in Taiwan and the Qing administration of Taiwan. ${ }^{31}$ Inō observed that the Qing administration in Taiwan, especially the administration of the aborigines, was largely one of neglect (xiaoji 消極 "passive") before 1875, at which time the government turned active and launched campaigns to subjugate the mountain aborigines, a reaction to the Japanese invasion of southern Taiwan in $1874 .{ }^{32}$ Similarly land settlement policies changed from restriction to encouragement in $1875 .{ }^{33}$ The idea that the Qing were passive about and neglectful of

\footnotetext{
${ }^{29}$ A theme that runs through Elliott, ibid. In particular, at 3, “...the Qing dynastic enterprise depended both on Manchu ability to adapt to Chinese political traditions and on their ability to maintain a separate identity". Emphasis original.

${ }^{30}$ For example, see Mark C Elliott "Review of Pei Huang Reorienting the Manchus: A Study of Sinicization" (2011) 54 Journal of the Economic and Social History of the Orient 584, at 585. For the Qing's inheritance of its legal system from the Ming, see, in particular, Zhang Jinfan Qingchao fazhishi [Legal history of the Qing Dynasty] (Zhonghua shuju, Beijing, 1998).

${ }^{31}$ Inō's most notable works include Taiwan banjin jijōo [Notes on Taiwanese aborigines] (Taiwan Sōtokufu, Taipei, 1900), Taiwan Banseishi [A history of aboriginal management in Taiwan] (Taiwan Sōtokufu, Taipei, 1904) and Taiwan bunkashi [A history of Taiwan's civilisation] (Tōkō Shoni, Tokyo, 1928). For an evaluation of Inō's contribution and lasting influence, see Paul D Barclay "An Historian among the Anthropologists: The Inō Kanori Revival and the Legacy of Japanese Colonial Ethnography in Taiwan" (2001) 21(2) Japanese Studies 117-136.

${ }^{32}$ Inō Kanori (trans Taiwan Historica) Taiwan wenhua zhi [A history of Taiwan's civilisation] (Chinese trans Rev ed, Taiwan Shufang, Taipei, 2011), vol 3, at 284 and 300.

${ }^{33}$ Part 14 "Tuozhi yange" [The history of land settlement], ch 1 and 2.
} 
Taiwan continued for decades in later research by Taiwanese scholars, ${ }^{34}$ as well as Western scholars. ${ }^{35}$

The above view was challenged in 1993, when John Shepherd suggested that the Qing administration of Taiwan was a careful balancing act of revenue and cost. ${ }^{36}$ Shepherd argued that the calculation of political economy led the Qing to devote itself to "accommodate" aboriginal land rights, which appears to mean a certain degree of recognition and protection of aboriginal land rights, or to consider the interests of both aborigines and settlers. ${ }^{37}$ Shepherd made a compelling case about the Qing policy rationale, but his study concerned only the period up to 1800 and only land rights of the plains aborigines. Further, the Japanese government also had to balance revenue and administrative cost, yet it took action to reform land tenure and increase revenue, rather than to minimise cost and accommodate aboriginal land rights as the Qing did. Some other factors had caused, or influenced, the Qing and the Japanese governments to make different choices, and one of the factors was the different legal cultures and traditions on governance. This is the focus of this thesis.

Shepherd also pointed out that the government, the Han Chinese settlers and the aborigines were three major players in the political scene of Qing Taiwan. ${ }^{38} \mathrm{Ka}$ Chih-ming further developed this concept and argued that Qing aboriginal land policies were a manipulation of ethnic politics. ${ }^{39}$ Like Shepherd, Ka focused on land rights of the plains aborigines before the end of the $18^{\text {th }}$ century - essentially the reigns of Kangxi, Yongzheng and Qianlong (1684-1795). Ka argued that, the Qing government used the plains aborigines to suppress Han rebellions and to contain the mountain aborigines in the mountains. As a

\footnotetext{
${ }^{34}$ For example, Tai Yen-hui "Qingdai Taiwan xiangzhuang zhi shehui de kaocha" [An investigation of the local society in Qing Taiwan] (1963) Taiwan yinhang jikan 198, at 198; Song Tsêng-chang "Qingdai Taiwan fuken cuoshi zhi chengxiao jiqi yingxiang" [The consequences and influences of the Qing's land and aboriginal policies in Taiwan] (1979) 30(1) Taiwan Wen Hsien 142, at 155.

${ }^{35}$ See a discussion on this in John Robert Shepherd Statecraft and Political Economy on the Taiwan Frontier, 1600-1800 (Stanford University Press, Stanford, 1993), at 3.

${ }^{36}$ At 5.

${ }^{37}$ This theme recurs throughout Shepherd's discussion. For example, at 5, 13, 242, 306 and 396.

${ }^{38}$ At 7 and 8.

${ }^{39}$ Ka Chih-ming Fantoujia: Qingdai Taiwan zuqun zhengzhi yu shufan diquan (The Aborigine Landlord: Ethnic politics and aborigine land rights in Qing Taiwan) (Academia Sinica, Taipei, 2003).
} 
reward, the government was protective of the land rights of the plains aborigines. ${ }^{40} \mathrm{Ka}$ 's argument about ethnic politics is consistent with the fact that the Qing rulers were skilful in managing and manipulating ethnic relationships, being minority rulers over China for nearly three centuries and governing a variety of peoples. The problem is that, according to $\mathrm{Ka}$, the protective policies emerged only in the mid-Qianlong reign, became mature in the late Qianlong reign and became redundant soon afterwards because Han settlement spread towards the territories of the mountain aborigines. ${ }^{41}$ Ka hence attributed the making, implementation and consequences of the Qing aboriginal land policies to a series of experiments and corrections of mistakes because of unexpected events in the course of history (lishi de jiyu 歷史的機遇), ${ }^{42}$ which suggests a lack of consistency and rationale.

Other scholars have also tried to find out the reasons for land loss by the plains aborigines. For example, through a case study on land tenure changes of the aboriginal Anli village, Chen Chiu-kun argued that aboriginal land tenure changes were the combined effect of local officials' ineffective implementation and distortion of government policies on the one hand, and the influence of the dominating Chinese land practice and commercial economy on the other. ${ }^{43}$ The experience of the Anli village to some extent represented that of the plains aborigines, but Chen did not turn his attention to the higher level of governance or policy-making.

Most studies on Qing aboriginal land policies have focused on the period before 1800, and few studies have focused on policies after 1800 and about the mountain aborigines. A notable one is by Chang Lung-chih, who examined debates within the government about expanding land settlement beyond the plains areas before 1875 and the policies after 1875. ${ }^{44}$ Chang concluded that 1875 signified the turning point of "Qing colonisation". ${ }^{45}$

\footnotetext{
40 At 25-26, and 363-370.

${ }^{41}$ At 364 and 370.

42 At 371-373, and 378 .

${ }^{43}$ Chen Chiu-kun Qingdai Taiwan tuzhu diquan: guanliao, handian yu Anlishe ren de tudi bianqian $1700-$ 1895 (Taiwan's Aboriginal Proprietary Rights in the Ch'ing Period: Bureaucracy, Han Tenants and the Transformation of Property Rights of the Anli Tribe, 1700-1895) (2ed, Academia Sinica, Taipei, 1997), in particular, at 132 and 218-219.

${ }^{44}$ Chang Lung-Chih "From Quarantine to Colonization: Qing Debates on Territorialization of Aboriginal Taiwan in the Nineteenth Century" (2008) 15(4) Taiwanshi yanjiu 1-30.

${ }^{45}$ In particular, at 4-5 and 23.
} 
This confirmed the traditional view which had been expounded by Inō and accepted by subsequent scholars. Chang focused on official discussions about whether to expand government administration and land settlement, and did not consider aboriginal land rights as such.

There have also been studies on Japanese colonial rule and land policies in Taiwan, but each with a different focus. Essays edited by Liao and Wang examined Japanese rule in Taiwan from the angles of colonialism and modernity, colonial policy and cultural change, and literary expression, but not aboriginal land tenure. ${ }^{46} \mathrm{Ka}$ Chih-Ming studied the agricultural development and the colonial economy in Taiwan during the Japanese period, and only touched on land tenure where rice and sugar production was concerned. ${ }^{47}$ Antonio Tavares's article focused on the Japanese manipulation of aboriginal property rights, but the attention was on Japanese management of the camphor forest, an aspect relating to the mountain aborigines' rights but not otherwise concerned with land tenure as a whole. ${ }^{48}$ Among those who addressed land tenure issues, Yen and Yang, as well as Lin Shu-ya, focused on the system of aboriginal reserves during the Japanese period and the implications and challenges for the current government. ${ }^{49} \mathrm{Li}$ Zhi-yin analysed the evolution of land registration systems under the Japanese and the subsequent Chinese regime, but was not especially concerned with the wider context of land tenure changes. ${ }^{50}$ None of the above studies have given attention to the connection between the Japanese colonial style and its aboriginal land policies.

So far there has been no research on how the respective styles of colonisation of the Qing and Japan, each shaped by its own legal system, determined their different aboriginal land policies and changed aboriginal land tenure in Taiwan. This thesis fills the gap. It examines

\footnotetext{
${ }^{46}$ Liao and Wang (eds), above n 26.

${ }^{47} \mathrm{Ka}$ Chih-Ming Japanese Colonialism in Taiwan: Land Tenure, Development, and Dependency: $1895-1945$ (Westview Press, Colorado, 1998).

${ }^{48}$ Antonio C Tavares "The Japanese Colonial State and the Dissolution of the Late Imperial Frontier Economy in Taiwan, 1886-1909” (2005) 64 Journal of Asian Studies 361-385.

${ }^{49}$ Yen Ai-ching and Yang Guo-zhu Yuanzhu minzu tudi zhidu yu jingji fazhan [Land tenure and economic development of the aborigine groups] (Daoxiang, Taipei, 2004); Lin, above n 2.

${ }^{50} \mathrm{Li}$ Zhi-yin "Taiwan tudi dengji zhidu bianqian zhi yanjiu" [The evolution of Taiwan land registration system] (LLM diss, Taiwan National Chengchi University, 2010).
} 
the whole length of Qing administration of Taiwan and uses Japanese policies as a comparison, and covers policies and land tenure changes about both the plains aborigines and the mountain aborigines. The thesis puts the study of Taiwan aboriginal land policies in the wider framework of the administration of Taiwan by governments whose legal systems were quite different, namely the Qing government, which in many respects was a traditional Chinese imperial regime, and Japan, which by the time it colonised Taiwan had reformed its law along European lines and which emulated a modern and European-style regime.

\section{Resource, Methodology and Thesis Structure}

There exist rich primary resources for study of Qing Taiwan, including government regulations, imperial decrees, palace memorials, administrative records, local gazetteers, ${ }^{51}$ land deeds and officials' private writings. Many of them are collected in the Taiwan Wenxian Congkan, a collection of historic records and literature that has been used by scholars in previous studies. ${ }^{52}$ Nevertheless given the large collection of the Congkan and this thesis' focus on legal analysis, the thesis explores details that have not been noted and also reinterprets some documents that have been discussed in earlier studies. In addition, other series of primary collections are consulted, such as Qinding Daqing huidian shili (regulations), ${ }^{53}$ Huangchao wenxian tongkao (regulations and decrees), ${ }^{54}$ Ming Qing Taiwan dang'an huibian (regulations, decrees and memorials), ${ }^{55}$ Dan Xin dang'an (government archives), ${ }^{56}$ and a number of land deeds collections. Where appropriate, this

\footnotetext{
${ }^{51}$ Gazetteers ( $z h i$ 志) are formal records of an administrative unit, such as a county, prefecture or province. They were compiled by local governments from time to time, and include official records as well as selected private writings about the administrative unit concerned.

${ }^{52}$ Taiwan Wenxian Congkan [Taiwan literature and documents collection] (Taiwan yinhang, Taipei, 19571975). The Collection contains 309 titles, and in this thesis they are indicated as TWWX followed by the series number of the title.

${ }^{53}$ Qinding Daqing huidian shili [Imperially approved precedents of the Great Qing Institutes, 1886] (Chinese Text Project www.ctext.org) ("Huidian shili").

${ }^{54}$ Huangchao wenxian tongkao [Comprehensive collection of important documents of the Qing Dynasty, 1797] (Chinese Text Project www.ctext.org) ("Wenxian tongkao").

${ }^{55}$ Taiwan Shiliao Jicheng Bianji Weiyuanhui Ming Qing Taiwan dang'an huibian [Collection of historic documents concerning Taiwan during the Ming and Qing Dynasties] (Yuanliu, Taipei, 2004-2009) ("Ming Qing dang'an").

${ }_{56}$ Wu Mi-cha (ed) Dan Xin dang'an [Administrative files of Danshui and Xinzhu Counties] (NTU, Taipei, 1995-2010).
} 
thesis uses case studies in certain localities by way of illustration, but it does not specifically study the developments of individual places or tribes. Many scholars have done fruitful work in this regard, forming rich resources for this thesis to draw upon.

Constrained by the space of the thesis and to enable in-depth analysis of the issues, this thesis focuses on the Qing period, and examines the Japanese period only for comparison purposes. For the Japanese period, some primary sources, where they exist in Chinese records or have been translated to the Chinese language, are consulted. These include legislation, the administrative files of the Taiwan Governor-General's Office (zongdufu dang'an 總督府檔案) and other materials compiled by the colonial government.

The thesis examines Qing policies towards land settlement in Taiwan, the extent of the government's recognition and protection of aboriginal land rights, the changes that the Qing property law regime brought to aboriginal land tenure, and the aborigines' interaction with the government and settlers regarding their land. The thesis then discusses the Japanese government's attitudes towards the aborigines and aboriginal land, and its reforms of land tenure in Taiwan. Ultimately, this thesis explores the role the Qing legal system played in shaping the policies and in transforming aboriginal land tenure, and how the Japanese legal system, largely westernised after the Meiji Restoration in 1868, influenced Japanese colonial policies regarding aboriginal land in Taiwan.

The thesis contains six main chapters, the first five on the Qing period, and the last one on the Japanese period. Chapter 1 introduces Taiwan's aboriginal groups and their land tenure, and reviews the process of land settlement before and during the Qing period. This chapter depicts the spread of Chinese settlement in Taiwan and sets the scene for later discussion.

Chapter 2 traces the policy trends of land settlement during the Qing period. It suggests that Qing policies in Taiwan could be divided into three stages, namely the controlling settlement stage between 1684 and the end of the $18^{\text {th }}$ century, the transitional stage from around 1800 to 1875 , and the promoting settlement stage after 1875. Chapter 2 argues that at each stage the determining factor for policy-making was consideration for territorial security and social stability, and this was underpinned by Chinese tradition on governance and theories about expansion. 
Chapter 3 analyses the Qing recognition and protection of aboriginal land rights during the above three stages. This chapter argues that the Qing property law regime and constitutional framework determined its recognition and protection of aboriginal land rights.

Chapter 4 traverses the influences of Chinese customary land practice on aboriginal land tenure. This chapter argues that it was Chinese customary land practice that changed aboriginal land tenure most, and caused the most loss of land by the aborigines. In the Chinese legal tradition, state law focused on criminal and administrative matters, and left property law and other personal law matters to customary law. This provided the dominant Chinese customary practice the opportunity to make substantive inroads into aboriginal land tenure.

Chapter 5 examines the aborigines' actions and reactions against Chinese settlement, including resistance, litigation, and adaptation and acculturation. The aborigines fought a losing battle, during which their land was taken away by settlers, their land rights diminished and their communities broken. This chapter demonstrates that colonisation was a two way contest, and the colonised reacted to defend their rights. However this at most slowed down the process of colonisation, and could not reverse the tide.

Chapter 6 discusses Japan's employment of modern international law theories in occupying the aboriginal territories of Taiwan, and its use of Western legal instruments to reform land tenure. It demonstrates how Japan, as a modernising neo-European colonial power, carried out its colonisation of Taiwan and deprived the aborigines of their land under the modernised legal framework.

The thesis concludes that the Qing was a coloniser of a different type, and the Qing colonisation of Taiwan was different from the later Japanese colonisation of Taiwan and from the Western styles of colonisation. Shaped by its legal culture, constitutional arrangement, administrative system and property law regime, the Qing government had little or no intention and took little action to transform aboriginal land tenure, which was one of the most important aspects of aboriginal society. Rather, the Qing legal framework 
allowed for or enabled Chinese settlers to manipulate aboriginal land tenure and impose Chinese culture on the aborigines, an effect often unintended by the government.

\section{Contribution and Limits}

When considering the various colonial administrations and their impacts on aboriginal land tenure around the Pacific, from Australia and New Zealand to Alaska, and others in between, Stuart Banner commented that "[d]ecisions made in the [past] about how to separate indigenous people from their land ... continue to shape our lives today". ${ }^{57}$ This statement is no less true for Taiwan's aborigines. Like most aboriginal groups, Taiwan's aborigines are now the minority in their own country and have lost most of their ancestral lands during the colonial past. Currently they are still battling with this past and are trying to gain recognition of and protection for their land rights, among other things. Given the continuing effects of historical events, it is hoped that interpretation of the historical government actions will provide lessons from the past and assist current endeavours. ${ }^{58}$

The experience of Taiwanese aborigines is not an isolated case. Their land tenure changes through the colonial past and their struggles for recognition of their rights in some aspects parallel similar loss, demands and indigenous politics in other countries, including Canada, the United States and Australia. It is hoped that this research will contribute to scholarly understanding not only of the process of land loss of the Taiwanese aborigines, but also of the international pattern of appropriation of aboriginal land and of colonialism in the age of decolonisation. In particular, this study forms a small part of a research in the land tenure changes in the Pacific Rim in the late $19^{\text {th }}$ and early $20^{\text {th }}$ centuries, and provides a vital supplement to the broad picture of Pacific Rim countries. ${ }^{59}$

\footnotetext{
${ }^{57}$ Banner, above $\mathrm{n} 8$, at 320 .

58 The current Taiwan President, Tsai Ing-wen, recently apologised to the aborigines for the colonial past. See Austin Ramzy “Taiwan's President Apologizes to Aborigines for Centuries of Injustice”, New York Times (Online ed, New York, 1 August 2016), Sinosphere.

${ }^{59}$ A research project led by Professor Richard Boast, the findings of which will be presented in For the Good of the Natives: Land and Society in the Pacific 1860-1940 (manuscript).
} 
This study is not an ethnohistory of the indigenous peoples of Taiwan. A great deal of valuable work has already been done on this important subject. ${ }^{60}$ Rather, the focus is on the legal traditions of the Qing Empire and, to a lesser extent, of post-Meiji Japan, and on how these legal traditions impacted on the development of policies relating to Taiwan.

This study focuses only on Taiwan, and more on the Qing period than on the Japanese period. Comparing Qing Taiwan policies to Qing policies on other frontiers, such as Xinjiang (central Asia), Mongolia, Manchuria, and the southwest provinces of Guangxi and Yunnan, will help to better understand patterns of Qing colonisation. Aboriginal land tenure during the Japanese period warrants more in-depth study and could be the subject of a separate thesis. The relationships between the $19^{\text {th }}$ century changes in the Japanese legal system and its general colonial policies are also worth close examination. For example, Japan's expansion to the land of the Ainu (present day Hokkaido) before the reforms of the Meiji era formed a stark contrast with its Ainu policies after the reforms and with Japanese colonisation of Taiwan. ${ }^{61}$ These are possible topics for future study.

\footnotetext{
${ }^{60}$ The Japanese administration instigated the study of Taiwan aborigines and published a series of works, including the works of Inō Kanori, noted in above n 31. More recently, Taiwan Historica published Taiwan yuanzhumin shi [History of Taiwan aborigines] (Taiwan Historica, Nantou), which includes one title on prehistory (Liu Yi-chang 2002); three titles on government policies (Fujii Shizue 2001, Peter Kang 2005 and Wen Chen-hua 2007) and two titles on the history of the plains aborigines (Chan Su-chuan and Chang Sufan 2001, Liang Chih-hui and Chuang Yu-lan 2001).

${ }^{61}$ For the history of Japanese colonisation of the Ainu land, see Takakura Shinichiro (trans John A Harrison) The Ainu of Northern Japan (The American Philosophical Society, Philadelphia, 1960).
} 


\section{Chapter 1 Land Settlement in Taiwan}

Taiwan, an island which used to be known by Europeans as Formosa, ${ }^{1}$ has been settled for thousands of years by aboriginal Austronesians. Taiwan is regarded by archaeologists and ethnohistorians as the ancestral homeland of the Austronesian peoples and of the Austronesian languages, which spread between Madagascar in the west and Easter Island in the east.

From the early $17^{\text {th }}$ century, successive outside forces established administrations in Taiwan. The first three administrations were relatively brief and controlled only parts of Taiwan - the Dutch East India Company (Vereenigde Oost-Indische Compagnie, the "VOC") for 38 years (1624-1662) in the southwest, the Spaniards for 16 years (1626-1642) in the north, and the Chinese Zheng family for 22 years (1662-1683), mainly in the southwestern plains. Following these brief periods of some overseas control, the Qing government ruled Taiwan for over two centuries (1684-1895). This was followed by 50 years' rule by Japan (1895-1945). The Republic of China took over Taiwan in 1945 after Japan's defeat in the World War II. Land settlement in Taiwan began with the arrival of the Dutch, and the spread of settlements unavoidably affected the aborigines.

Local history of land reclamation in different historical periods has been the subject of in depth study, and much has been discovered about the spread of Han settlement in Taiwan. ${ }^{2}$ This chapter therefore focuses on setting the scene for the thesis, as well as identifying a settlement pattern and demonstrating the effect of land settlement on the aborigines. Part I presents the aborigines as they were known at different historical periods and outlines their status in Taiwan today. This Part points out that the various statuses of the different aboriginal groups were the result of varying degrees of acculturation in the history. Parts II and III depict the historical background up to the Qing period - Part II outlines the succession of different regimes in Taiwan, and Part III discusses aboriginal land tenure in

\footnotetext{
${ }^{1}$ Portuguese for "beautiful".

${ }^{2}$ For example, Song Tsêng-chang Taiwan fuken zhi [History of aboriginal management and land reclamation in Taiwan] (2ed, Taiwansheng wenxian weiyuanhui, Taizhong, 1997) documents land reclamation in Taiwan; Sheng Ch'ing-I "Xinzhu, Taoyuan, Miaoli sanxian diqu kaifashi" [The history of reclamation in the three counties of Xinzhu, Taoyuan and Miaoli] (1980) 31(4) \& (1981) 32(1) Taiwan Wen Hsien 154-176 (Part I); 136-157 (Part II) explores the history of land reclamation in certain areas.
} 
Taiwan, and land policies and settlement during the Dutch and the Zheng periods. Part IV examines land settlement during the Qing period, and finds that land settlement throughout the $17^{\text {th }}$ to $19^{\text {th }}$ centuries was a slow but continuous expansion. Part V summarises the pattern of land settlement and concludes that the varying degrees of acculturation of the aborigines were the result of land settlement patterns.

\section{Taiwanese Aborigines}

The Taiwanese aborigines are Austronesian-speaking peoples. Austronesian, meaning "southern islands", is a large language family which consists of at least 10 primary subgroups, nine of which are present only in Taiwan. ${ }^{3}$ The tenth is the widely dispersed Malayo-Polynesian languages, spoken by peoples in Southeast Asia and the Pacific islands, including mainland Southeast Asia, the Philippines, Indonesia, Micronesia, Melanesia, Polynesia and Madagascar. ${ }^{4}$ It is therefore believed that Taiwan is the originating place for all Austronesians. ${ }^{5}$

The knowledge about the Taiwanese aborigines increased as contact with them increased, but it was during the Japanese period that anthropological study of the aborigines started.

\section{A Empirical Understanding about the Aborigines in the Early Stage}

The earliest records about the Taiwanese aborigines were made before the Dutch colonisation. Many observers recorded their observations of the Taiwanese aborigines in the subsequent centuries.

Two brief eyewitness accounts about some "barbarian" peoples (fan 番) of pisheye 毗舍 耶, written in the Song Dynasty (960-1279) and Yuan Dynasty (1271-1368) respectively,

\footnotetext{
${ }^{3}$ Robert Blust The Austronesian Languages (revised ed, ANU, Canberra, 2013), at 30. Also see David Blundell "A Century of Research: Austronesian Taiwan, 1897-1997" in David Blundell (ed) Austronesian Taiwan: Linguistics, History, Ethnology, Prehistory (Rev ed, Shung Ye Museum of Formosan Aborigines, Taipei; Phoebe A Hearst Museum of Anthropology, Berkeley, 2009), 3, at 8-9. For the history, cultures and societies of the Austronesians, see Peter Bellwood, James J Fox and Darrell Tryon (eds) The Austronesians: Historical and Comparative Perspective (ANU E Press, Canberra, 2006).

${ }^{4}$ Blust, ibid; Darrell Tryon "Proto-Austronesian and the Major Austronesian Subgroups" in Bellwood, Fox and Tryon (eds), ibid, 19, at 37-38.

${ }^{5}$ Robert Blust "The Prehistory of the Austronesian-Speaking Peoples: A View from Language" (1995) 9(4) Journal of World Prehistory 453, at 458 and 460.
} 
have been recognised as describing the aborigines of Taiwan. ${ }^{6}$ In 1603 a Chinese traveller, Chen Di, published a relatively detailed description of the Taiwanese aborigines in the western plains areas. ${ }^{7}$ The record notes that the aborigines were "very diverse in kinds" (zhonglei shenfan 種類甚繁), and dwelt together in groups known as “villages” (she 社). Village sizes varied from 500 or 600 to around 1,000 people, and there was no political leader. The aborigines knew basic agriculture, made a fermented beverage from rice, kept limited types of domesticated animals, were engaged in deer hunting, and traded deer products for other commodities with merchants from mainland China. The people practised head hunting, went about naked, but had commonly observed laws and etiquettes, such as prohibition against thieves and etiquette regarding death and marriage. ${ }^{8}$ Although the record mentions that the aborigines were scattered at different locations which extended "over a thousand $l i$ ", the author spent most of his time in the Bay of Tayouan (Dayuan 大 員, present day Anping, near Tainan), where the Dutch later built their power base. Therefore it is likely that the author was describing the aborigines around that area.

After the Dutch arrived in the southwest of Taiwan in 1624, they eventually established contacts with the villages near its base, Tayouan. The Dutch found the eight aboriginal villages near Tayouan shared the same customs and language, but were independent from one another. ${ }^{9}$ The Dutch records are more elaborate than Chen Di's record, but they show no material difference from Chen's observations about the aborigines. ${ }^{10}$ The Dutch missionary work bore fruit mostly among the aboriginal villages near Tayouan, namely Sinkang, Bakloan, Soulang, Mattau and Tavakan. ${ }^{11}$ These aborigines also acquired a Romanised written form of their language which they used till the Qing period. ${ }^{12}$ The

${ }^{6}$ The two works are Zhao Rugua Zhufanzhi [Accounts of various barbarians] (TWWX 119), and Wang Dayuan Daoyi zhilüe [Brief accounts of the island barbarians, 1349] (TWWX 119). Both descriptions are brief. See Laurence G Thompson "The Earliest Chinese Eyewitness Accounts of the Formosan Aborigines" (1964) 23 Monumenta Serica 163 for English translation of the latter record.

${ }^{7}$ Chen Di Dongfanji [Accounts of the eastern barbarians, 1603], collected in Shen Yourong Minhai zengyan [Words of praise from the Fujian sea] (TWWX 56), at 24-27. See Thompson, ibid, for English translation.

8 Ibid.

${ }^{9}$ William Campbell Formosa under the Dutch (Kegan Paul, Trench, Trubner, London, 1903), at 9 and 15.

${ }^{10}$ See Part I ch 2 "Account of the Inhabitants".

11 At 179-180. The aborigines of these villages are now known to belong to the Siraya group.

12 There exist bilingual land deeds, in the Sirayan and Chinese languages, that the Sirayan concluded with the Chinese during the early to mid-Qing period. 
Dutch later encountered more aboriginal villages in other parts of the island, and found them to differ in size, custom, language and political organisation. The size of the aboriginal villages varied from a few hundred to a few thousand inhabitants, and some of them had no chief while others did. ${ }^{13}$ At the southern end of Taiwan, in the area of Longkiau (Langqiao 榔嶠), the Dutch agent found 15 villages under one chief. ${ }^{14}$ In about the middle point of the western plains, around the villages of Darida (Dadu 大肚), a chief called “the King of Darida" (Daduwang 大肚王) controlled large areas, and enjoyed tribute from other villages as well as judicial authority. ${ }^{15}$ A census carried out by the Dutch in 1650 recorded over 68,000 aborigines in the 315 villages that had submitted to Dutch authority. ${ }^{16}$ A rough estimation of the aboriginal population in 1654 was $100,000 .{ }^{17}$

The Spaniards were established in Tamsui (Danshui 淡水) and Quelang (Jilong 基隆) at the northern tip of Taiwan between 1626 and 1642. There they encountered a people now known as Basayans. The Basayans were not farmers or head hunters. They were craftsmen and traders, going through the villages and trading with the Chinese and other aboriginal groups, and often served as intermediary between those two communities. ${ }^{18}$ After the Dutch replaced the Spaniards in the north, they found some natives that could read Spanish. ${ }^{19}$ However in general the Spaniards had few dealings with the natives in the Taipei Basin, ${ }^{20}$ or those in the Kavalan area at the northeast of Taiwan, ${ }^{21}$ which was on the maritime route between Jilong and Manila. ${ }^{22}$

\footnotetext{
${ }^{13}$ Campbell, above n 9, at 15 and 137. At 180 it indicates that one of the villages had at least 3000 people.

${ }^{14}$ At 137. These villages are now known to belong to the Paiwan group.

15 These aboriginal villages are now known to belong to the Papora group. See Peter Kang Taiwan yuanzhumin shi zhengce pian: He Xi Mingzheng shiqi [History of Taiwan aborigines: the policy chapter: the Dutch, Spanish and Zheng periods] (Taiwan Historica, Nantou, 2005), at 27-28.

${ }^{16}$ See Chuang Sung-lin "Helan zhi Taiwan tongzhi" ("Dutch Administration in Formosa") (1959) 10(3)

Taiwan Wen Hsien 1, at 3.

${ }^{17}$ Campbell, above n 9, at 64.

${ }^{18}$ See José Eugenio Borao Mateo The Spanish Experience in Taiwan 1626-1642: The Baroque Ending of a Renaissance Endeavor (Hong Kong University Press, Hong Kong, 2009), ch 3.

${ }^{19}$ Campbell, above $\mathrm{n} 9$, at 231.

${ }^{20}$ Now known as the Ketagalan group, of which Basay is a subgroup.

${ }^{21}$ Now known as the Kavalan group.

22 Borao Mateo, above n 18, ch 3, in particular at 60 and 63.
} 
The Zhengs left little record about the aborigines during their brief rule over Taiwan, but it is known that the Zheng government divided the aborigines that came under its administration into four districts and appointed ten officers to administer these districts. ${ }^{23}$ By the time the Qing traveller Yu Yonghe visited Taiwan in 1697, he found that the aboriginal villages around Tayouan were similar to villages in mainland China. Yu was told that the villagers of Sinkang, Bakloan, Soulang and Mattau had paid tax and had been educated under the Chinese system since the Zheng period. ${ }^{24}$

As in earlier Chinese records, the Zhengs and the Qing referred to the Taiwanese aborigines as fan, which, together with terms such as $y i$ 夷, di 狄 and man 蠻, were used to denote those outside Chinese civilisation. The Qing government continued the Dutch and Spanish method of identifying the aborigines by areas of habitation, rather than by their different ethnolinguistic characteristics. A study of the aborigines conducted in 1722 by an Inspecting Censor for Taiwan (xun Tai yushi 巡薹御史), Huang Shujing, classified the aborigines as “the northern route aborigines" (beilu fan 北路番) and “the southern route aborigines" (nanlu fan 南路番), according to their geographic locations in relation to the prefecture capital. ${ }^{25}$ There were 10 clusters of the northern aborigines and three clusters of the southern aborigines. Each cluster had a group of villages, and in total 151 villages were recorded, with some big villages containing a number of small villages. It appears that the recorded villages were those that were under government administration, although the degree of government control and the burden of tax varied among the villages. The arrangement of clusters, apart from being based on geographic locations, was probably also related to tax collection. Huang seemed to recognise that the villages within a cluster shared the same culture and language, as he described the culture of each cluster as a whole, under six headings - housing, food, costume, marriage, burial, and household objects and tools. Included in each cluster were also lyrics of the aborigines' folk songs, which suggested that

\footnotetext{
23 Hung Chien-Chao "Taiwan under the Cheng Family: Sinicization after Dutch Rule" (PhD diss, Georgetown University, 1981), at 132. The four districts probably refer to the four villages of Sinkang, Bakloan, Soulang and Mattau.

${ }^{24} \mathrm{Yu}$ Yonghe Bihai jiyou [Small sea travelogue, 1697] (TWWX 44), at 17.

${ }^{25}$ Huang Shujing Taihai shichalu [Records of a tour on duty over the Taiwan seas, cir 1722] (TWWX 4). After a major Han uprising in 1721, Inspecting Censors regularly visited Taiwan to inspect the situation there and report it to the Emperor.
} 
the villages within each cluster shared a common language. ${ }^{26}$ Modern research shows that Huang's grouping of some of the clusters was consistent with later ethnolinguistic classification of some aboriginal groups. ${ }^{27}$

By the time the revised gazetteer of Taiwan Prefecture was compiled in 1741, 244 villages were recorded by name. ${ }^{28}$ The number was increased to 299 within a few years. ${ }^{29}$ The increase in number was a mixture of factors, including different recording methods, increased knowledge about the aborigines and expanded government control, as well as subdivision of some villages. For example, traditionally 36 villages dwelt in Gamalan (噶 瑪蘭 Kavalan). Huang Shujing noted the 36 villages, but only counted them as one Gamalan village. ${ }^{30}$ Similarly, traditionally there were 18 villages in the southern areas of Langqiao. While Huang listed the 18 villages within one cluster, the 1741 revised gazetteer only recorded Langqiao as one village, and the subsequent 1747 revised gazetteer reverted it back to 18 villages. ${ }^{31}$

The above knowledge about the aborigines acquired before and during the Qing period was through observation by travellers or officials who came into contact with the aborigines. This was different from that under the Japanese government which organised systematic modern anthropological studies on the aborigines, and which is an example of the different style of the Japanese colonisation from Qing colonisation.

\section{B Anthropological Knowledge about the Aborigines}

Modern anthropological study of the Taiwan aborigines started soon after Japan took over. $^{32}$ The Japanese anthropologist Inō Kanori, dispatched by the colonial government,

\footnotetext{
${ }^{26}$ Ibid. The volume on the aborigines study is called "Fansu liukao" [Examination of the aborigines' customs from six aspects].

${ }^{27}$ Pan Ying Taiwan yuanzhu minzu de lishi yuanliu [History of the Taiwanese aboriginal groups] (Taiyuan, Taipei, 1998), at 75-76.

${ }^{28}$ Liu Liangbi Chongxiu Fujian Taiwan fuzhi [Revised gazetteer of Taiwan Prefecture, Fujian, 1741] (TWWX 74), at 80-91.

${ }^{29}$ See Fan Xian Chongxiu Taiwan fuzhi [Revised gazetteer of Taiwan Prefecture, 1747] (TWWX 105), at 6973.

${ }^{30}$ Huang, above n 25, at 141 .

${ }^{31}$ Ibid, at 155-156; Liu, above n 28, at 81; Fan, above n 29, at 70.

${ }^{32}$ See essays in Blundell (ed), above n 3, for accounts of linguistics, history, ethnology and archaeology studies of the Taiwanese aborigines.
} 
conducted research on the aborigines and classified the aborigines of Taiwan into eight main groups: Atayal 泰雅, Bunun 布農, Tsou 鄒, Tsalisen (later known as Rukai 魯凱), Paiwan 排灣, Puyuma 卑南, Ami 阿美 and Pepo 平埔. ${ }^{33}$ The first seven groups were mountain aborigines, while the group of Pepo (pingpu 平埔, literally “flat land") was in fact the generic term for the aborigines on the plains area. By the time of Inō Kanori's work, the plains aborigines had been largely sinicised through 200 odd years of contact with the Chinese migrants.

The seven mountain groups, together with the Yami 雅美 of Orchid Island (an island off the south-eastern coast of the main island of Taiwan), and the group of Saisiyat 賽夏 which was later identified as mountain aborigines, were the "traditional nine groups" recognised as the aborigines of Taiwan by the Japanese government and the subsequent Chinese Kuomintang (國民黨 “national party”) government. ${ }^{34}$ The Japanese administration also established a committee for investigation of aborigines (Taiwan Sōtokufu Banzoku Chōsakai 臺灣總督府蕃族調查會), which organised systematic research on the aboriginal groups between 1909 and 1912. This was in itself part of the "modern" Japanese administration - conducting historical and anthropological research on the colonies, like Britain or France did. ${ }^{35}$ The committee subsequently published research reports on the aboriginal groups and their languages and customs. ${ }^{36}$

\footnotetext{
${ }^{33}$ James W Davidson The Island of Formosa: Past and Present (MacMillan, London and New York, 1903), at 561; Takekoshi Japanese Rule in Formosa, above "Introduction" n 6, at 219.

${ }^{34}$ For a thorough survey of the study and classification of the Taiwan aboriginal groups, see Pan, above n 27, in particular, ch 3 .

${ }^{35}$ See Yao Jen-To "The Japanese Colonial State and Its Form of Knowledge in Taiwan" in Liao and Wang (eds) Taiwan under Japanese Colonial Rule, above "Introduction" n 26, at 37-71 for the extensive research the Japanese administration conducted on Taiwan and its inhabitants. For the correlation between anthropology and colonialism, see Akitoshi Shimizu "Colonialism and the Development of Modern Anthropology" in Jan van Bremen and Akitoshi Shimizu (eds) Anthropology and Colonialism in Asia and Oceania (Curzon Press, Surrey, 1999) 115. Also see Bernard S Cohn Colonialism and its Forms of Knowledge: The British in India (Princeton University Press, Princeton, 1996).

${ }^{36}$ Banzoku chōsa hōkokusho 蕃族調查抟告書 [Investigation reports on the savage peoples] and Banzoku kanshū chōsa hōkokusho 蕃族慣習調查報告書 [Investigation reports on the customs of the savage peoples] respectively, Chinese translated versions are Taiwan fanzu diaocha baogaoshu (Academia Sinica, Taipei, 2007) and Taiwan fanzu guanxi diaocha baogaoshu (Academia Sinica, Taipei, 1996-2003).
} 
Inō identified 10 different groups within the Pepo group. ${ }^{37}$ Later scholars proposed slightly different numbers or groupings, but most of the differences seem to be whether a certain group was an independent group or a sub-group of another group. ${ }^{38} \mathrm{~A}$ recent study by a Taiwanese linguist proposes that, from a linguistic perspective, the plains aborigines could be classified into six groups, which contain eight previously well recognised groups: Baburan 巴布蘭 (including subgroups of Taokas, Papora, and Babuza), Kavalan 噶瑪蘭, Ketagalan 凱達格蘭 (including Basay, Luilang and Trobian), Hoanya 洪雅, Pazeh 拍宰海 and Siraya 西拉雅 (including Siraya, Makattao and Taivoan). ${ }^{39}$ Scholars disagreed on whether the seventh group, Thao 邵, was a plains or mountain aborigine group..$^{40}$ Recent scholarship seems to lean towards the opinion that it was a mountain group. ${ }^{41}$

Although there has been no complete agreement on the numbers and grouping of the Taiwan aborigines, a recent ethno-language report is helpful in giving an overview of the Austronesian languages spoken in Taiwan and their current status. ${ }^{42}$ According to this report, at least 21 Austronesian languages have been spoken in Taiwan. These 21 languages belong to 14 language families, and each has some dialects. ${ }^{43}$ Among the 21 languages, four are now extinct, two have no known first language speakers, and five more have fewer than 100 speakers (see Chart 1).$^{44}$ The plains aboriginal groups' languages are now extinct or nearly extinct, and the people are all sinicised. ${ }^{45}$

\footnotetext{
${ }^{37}$ Davidson, above n 33, at 580-581.

${ }^{38}$ See Pan Ying Taiwan pingpuzu shi [History of the Taiwanese plains aborigines] (Nantian, Taipei, 1996), at 35-36.

${ }^{39}$ Paul Jen-kuei Li "Taiwan pingpuzu de zhonglei jiqi xianghu guanxi" [The classification of Taiwanese plains aborigines and their inter-relationships] in Zhang Yan-xian, Li Xiao-feng and Dai Bao-cun (eds) Taiwanshi lunwen jingxuan [Selected essays on Taiwan history] (Yushan, Taipei, 1996) 43, at 46 and 61.

${ }^{40}$ At 46. Also see Paul Jen-Kuei Li "Formosan Languages: The State of the Art" in Blundell (ed), above n 3 , 47, at 52; Pan, above n 27, at 118.

${ }^{41}$ See Kang, above $\mathrm{n} 15$, at 30 , note 1.

${ }^{42}$ M Paul Lewis, Gary F Simons and Charles D Fenning (eds) "Ethnologue: Languages of Taiwan", Ethnologue: Languages of the World (18 ${ }^{\text {th }} \mathrm{ed}$, online ed, SIL International, Dallas, Texas, 2015).

${ }^{43}$ At 11-23.

44 Ibid.

${ }^{45}$ Ibid. Also see Blundell "A Century of Research", above n 3, at 8.
} 
Chart 1 Taiwan Aboriginal Language Groups according to Ethnologue

\begin{tabular}{|l|l|l|l|}
\hline Languages & Plains/Mountains & $\begin{array}{l}\text { Language/Cultural } \\
\text { status }\end{array}$ & $\begin{array}{l}\text { Government } \\
\text { recognition* }\end{array}$ \\
\hline Amis & Mountains & Developing & Yes \\
\hline Amis Nataoran & M & Nearly extinct & Sakizaya 2007 \\
\hline Atayal & M & Developing & Yes \\
\hline Bunun & M & Developing & Yes \\
\hline Kanakanabu & M & Nearly extinct & 2014 \\
\hline Paiwan & M & Developing & Yes \\
\hline Puyuma & M & Shifting & Yes \\
\hline Rukai & M & Developing & Yes \\
\hline Saaroa & M & Nearly extinct & Hla'alua 2014 \\
\hline Saisiyat & M & Threatened & Yes \\
\hline Taroko & M & Educational & Sediq 2008 \\
Truku 2004 \\
\hline Thao & Mountain/Plain & Nearly extinct & 2001 \\
\hline Tsou & M & Vigorous & Yes \\
\hline Yami & On Orchid Island & Threatened & Yes \\
\hline Babuza & Plains & $\begin{array}{l}\text { Dormant. } \\
\text { Sinicized }\end{array}$ & \\
\hline Basay & P & Extinct. Sinicized & \\
\hline Kavalan & & $\begin{array}{l}\text { Nearly extinct. } \\
\text { Sinicized }\end{array}$ & 2002 \\
\hline Ketagalan & P & Extinct. Sinicized & \\
\hline Kulon-Pazeh & P & Extinct. Sinicized & \\
\hline Papora-Hoanya & P & Extinct. Sinicized & \\
\hline Siraya & P & $\begin{array}{l}\text { Dormant. } \\
\text { Sinicized }\end{array}$ \\
\hline
\end{tabular}

*The groups that are marked "Yes" are the "traditional nine groups" noted since the Japanese period and were recognised by the Ministry of the Interior of Taiwan in 1954. See Pan (1998), at 94.

Currently the Taiwan government recognises 16 language groups as the aborigines of Taiwan (see Chart 1). The official recognition is not a static process and it is possible that new groups may be recognised in the future. The 16 groups were recognised at different stages, and in addition about 15,000 people identified themselves as aborigines but as not belonging to any of the 16 groups. ${ }^{46}$ As can be seen from Charts 2 and 3, the recognised aboriginal groups all live in the mountain areas or in eastern Taiwan - "at the back of the mountains" (houshan 後山), as the Qing officials would call it. All are classified as mountain aborigines except Kavalan. The aboriginal groups that are not recognised have

\footnotetext{
${ }^{46}$ The Republic of China Yearbook 2015, above "Introduction" n 1, at 49.
} 
acculturated to the dominant Han culture and lost their distinctive languages and culture. As will be shown later in this chapter, this situation is the consequence of land settlement.

Chart 2 Taiwan and Nearby Islands (source: ROC Yearbook 2015, at 41)

Map removed as permission to reproduce has not been granted 
Chart 3 Aboriginal Groups Recognised by the Current Taiwan Government (adapted from source and maps by Council of Indigenous Peoples, Taiwan, www.apc.gov.tw)

Map removed as permission to
reproduce has not been granted

* Three small groups, who also live in the mountains, are not shown on this map: Sediq, Hla'alua and Kanakanabu.

\section{Successive Foreign Administrations}

\section{A Early Contacts}

Taiwan measures about 35,808 square kilometres, being about 400 kilometres from north to south, and about 145 kilometres from west to east at its widest. Converting to the measurement that was used during the Zheng, the Qing and most of the Japanese periods, the total land area is just over 3.7 million jia. As shown in Chart 2, central mountain ranges run from the north to the south, occupying about half of the island. ${ }^{47}$ West of the mountain ranges are fertile plains, and east of the mountains are scattered lowlands.

Being separated from its nearest neighbour, the mainland of China, by the Taiwan Strait at about 130 kilometres at its narrowest and 220 kilometres at its widest, and being about

${ }^{47}$ See ibid for Taiwan geography. The total area is about one seventh the size of New Zealand. 
1,100 kilometres south of Japan, Taiwan was relatively isolated and the aborigines were their own masters until the $17^{\text {th }}$ century. Chinese records as early as the $3^{\text {rd }}$ and $7^{\text {th }}$ centuries referred to Taiwan, ${ }^{48}$ but the Chinese had shown little interest in acquiring the territory. The Song Dynasty (960-1279) established administration on the Pescadores archipelago (Penghu 澎湖), which lie between Taiwan and mainland China, but control was intermittent during the subsequent Yuan (1271-1368) and Ming (1368-1644) dynasties. ${ }^{49}$ Chinese merchants were present in Taiwan by the 1340s. In 1430, the Ming Dynasty admiral Zheng He visited Taiwan during one of his voyages, but apart from taking back with him some native herbs, nothing ensued from the visit. ${ }^{50}$

By the second half of the $16^{\text {th }}$ century, fishermen and merchants from coastal Fujian Province sailed to Taiwan regularly and some settled there, although the number was small. ${ }^{51}$ During the late Ming period, Chinese and Japanese pirates also used Taiwan as a base for their activities. The Japanese government sent envoys to Taiwan to demand tributes and request trade in 1593 and 1609, and sent 13 boats in 1615 with the intention of invading Taiwan, but without success. ${ }^{52}$ Japan soon entered a period of self-imposed isolation called sakoku (Ch Suoguo 鎖國) in 1633, and as a result abandoned any effort to assert a Japanese presence in Taiwan.

\section{B European Control}

The lack of interest on the part of the late Ming government and the changed policy in Japan gave the Dutch an opportunity to become the first colonisers of Taiwan. In fact it was Chinese officials who induced the Dutch to settle in Taiwan. ${ }^{53}$ To obtain a trade relationship with the then Ming China, the Dutch forcefully established themselves on the

\footnotetext{
${ }^{48}$ Albeit under different names. See Inō Taiwan wenhua zhi, above "Introduction" n 32, vol 1, Section 1 "Qingdai yiqian zhongguoren suozhi zhi Taiwan" [Taiwan as known by the Chinese before the Qing Dynasty].

${ }^{49}$ At 20, and 23-24.

${ }^{50}$ At $25-26$

${ }^{51}$ Campbell, above n 9, Part 1.

${ }^{52}$ As there was no unified political unit in Taiwan, the envoy found no one to receive the letter in the 1593 attempt. In the second attempt conflicts occurred with the aborigines. It is not clear what happened to the last attempt. See Inō, above n 48, at 28-34.

${ }^{53}$ Dutch record acknowledged that Taiwan belonged to the Chinese Emperor who "granted" Taiwan to the VOC. See Campbell, above n 9, at 27, 32 and 36.
} 
Pescadores in 1622, which was then under Chinese administration. After some battles and negotiation, Chinese officials persuaded the Dutch to settle in Taiwan by promising to send goods to Taiwan for trade. In 1624, the Dutch landed on Tayouan. Tayouan was a small isle that was an arrow shot away from the southwest end of the main island. The Dutch built Fort Zeelandia on Tayouan. Later they purchased a piece of land from the aboriginal village of Saccam on the main island, just opposite Fort Zeelandia, where they built Fort Provintia.

To the Dutch, Taiwan was valuable not in itself but as a potential base for establishing commercial relationships with China. ${ }^{54}$ However eventually the Dutch were involved in the local politics of the aboriginal groups and were able to exercise influence and control over the nearest five villages, with many villagers converting to Christianity. ${ }^{55}$ As for the more distant aboriginal villages that subsequently surrendered, the Dutch had clergymen live in a small number of villages and set up schools there, and held an annual assembly of village headmen. Other than these, it does not seem that the Dutch established any administration or exercised effective control over them. ${ }^{56}$

In an effort to compete with the Dutch, the Spaniards occupied northern Taiwan in 1626. This was part of the world-wide commercial and economic conflict between Spain - which at this time included Portugal and the Portuguese possessions in Asia - and the Protestant Dutch Republic. ${ }^{57}$ The Spanish built two small fortresses, one at the entrance to the Jilong harbour, the other at the mouth of the Danshui River. Extensive research has been done on the brief Spanish era in Taiwan, which shows that Spanish activities in Taiwan were limited. ${ }^{58}$ At any time there were no more than a few hundred Spaniards present, and the trade with the aborigines was confined to provisions for the soldiers. ${ }^{59}$ The lack of trading

\footnotetext{
54 Part 1 ch 3 "History of the Dutch Trade".

55 At 180 and 212.

56 See ibid, Part 2 in general. Also see I-shou Wang “Cultural Contact and the Migration of Taiwan's Aborigines: A historical perspective" in Ronald G Knapp (ed) China's Island Frontier: studies in the historical geography of Taiwan (University Press of Hawaii, Honolulu, 1980) 31, at 35.

57 See Borao Mateo, above n 18, especially ch 1, for Dutch-Spanish rivalry in Southeast Asian and the Taiwan Strait.

${ }^{58}$ Ibid, in general.

${ }^{59}$ At 155.
} 
opportunities led to neglect of the fortresses, which resulted in the Dutch successfully ousting the Spaniards in 1642. The Spanish era left no permanent mark on Taiwan or its aborigines.

\section{Chinese Administration}

At about the same time, China experienced a major dynastic change. In 1636, the Manchu Khan Hung Taiji announced the formation of the Qing Dynasty in the northeast of China. In 1644, two years after the Dutch ousted the Spaniards from northern Taiwan, the Ming Dynasty collapsed under peasant rebellion. Within a few months the Manchus entered Beijing, drove out the rebels, and established their rule over China. ${ }^{60}$ This event was one of the most important turning points in Chinese history, and was to have significant impacts on Taiwan.

Some remnant Ming forces continued to resist the Qing. The most powerful force was that of Zheng Chenggong (known to the West as Koxinga) in south China. Zheng's father was a pirate turned Ming official, using his large fleets to guard the Chinese coast against pirates. Zheng's father eventually defected to the Qing, but Zheng continued to fight against the Qing in south China and tried to restore the Ming regime. ${ }^{61}$ Hard-pressed by the Qing, in late 1661 Zheng's army attacked the Dutch in Taiwan, with the purpose of obtaining an overseas foothold to continue his resistance against the Qing. After five months of siege, the Dutch in Fort Zeelandia surrendered in early 1662, following the surrender of Fort Provintia earlier. ${ }^{62}$

\footnotetext{
${ }^{60}$ For the late Ming history and the collapse of the Ming, see William Atwell “The T'ai-ch'ang, T'ien-ch'i, and Ch'ung-chun reigns, 1620-1644" in Frederick W Mote and Denis Twitchett (eds) The Cambridge History of China Volume 7: The Ming Dynasty, 1368-1644 Part One (Cambridge University Press, Cambridge, 1988) 585-640. For the rise of the Qing and the entry to China, see Gentraude Roth Li "State Building before 1644" and Jerry Dennerline "The Shun-chih Reign" in Willard J Peterson (ed) The Cambridge History of China Volume 9: The Ch'ing Dynasty to 1800 Part One (Cambridge University Press, Cambridge, 2002) 9-72 and 73-119.

${ }^{61}$ See Lynn A Struve "The Southern Ming, 1644-1662” in Mote and Twitchett (eds), ibid, 641-725, in particular, at 710-725 for Zheng Chenggong's missions.

${ }^{62}$ See Campbell, above n 9, Part III "Chinese Conquest of Formosa", for accounts of the Zheng conquest of Dutch Taiwan. For a more colourful narrative of the events, see Tonio Andrade Lost Colony: The Untold Story of China's First Great Victory over the West (Princeton University Press, Princeton and Oxford, 2011).
} 
The Zheng regime used Taiwan as a military base for recovery of mainland China from the Qing. Viewing themselves as the preservers of Ming legitimacy and governing Taiwan as a part of the collapsed Ming China, the Zhengs established their central government as a prefecture, Chengtian 承天 Prefecture, with two counties below it, Tianxing 天興 and Wannian 萬年. The administrative centre was at Tayouan, and Zheng renamed it Anping. Zheng Chenggong soon died and was succeeded by his son Zheng Jing. Zheng Jing carried on the mission in fighting against the Qing. Three years after Jing's death in 1680, the Zhengs surrendered to the Qing. ${ }^{63}$ The Zhengs ruled Taiwan for 22 years. Although the history of the Zheng resistance to the Qing is well-known, there is little information available on their administration of Taiwan.$^{64}$ Nonetheless, Zheng rule marks an important stage in Taiwanese history as it established the first Chinese-style government on Taiwan, albeit as part of a rump Ming loyalist state fighting a losing battle against the Qing.

\section{Qing Annexation}

In 1684, the Qing annexed Taiwan, making it a prefecture under Fujian Province with the new name Taiwan Prefecture. The prefecture capital remained in the same place, and a new county named Taiwan was established on the capital. The two Zheng counties were renamed Zhuluo 诸罗 and Fengshan 凤山 counties respectively. Fengshan was situated to the south of Taiwan County, and Zhuluo to the north. The administration in Taiwan did not change much for nearly two centuries, until the last 20 years of the Qing rule of Taiwan when the administration was expanded. Taiwan was made a province in 1887, signifying its growing importance in the eyes of the Court by this time. Modernising efforts were made, including building infrastructure and establishing mining and trade. But the efforts were not consistent and were short-lived. Within a few years the Qing surrendered Taiwan to Japan, ending its 211 years' administration of Taiwan.

\footnotetext{
${ }^{63}$ See Kawaguchi Choju Taiwan Zhengshi jishi [Chronicles of the Zhengs of Taiwan, 1828] (TWWX 5) for the rise and fall, and the administration, of the Zhengs in Taiwan.

${ }^{64}$ For a recent discussion on the Zhengs in Taiwan, see Kang, above n 15, ch 15 .
} 


\section{Land Tenure in Taiwan before the Qing}

\section{A Aboriginal Land Tenure}

The Taiwanese aborigines' principal means of livelihood was deer hunting, as well as gathering, small scale fishing and limited farming. ${ }^{65}$ Chinese travellers before the Dutch time recorded primitive horticulture activities by the aborigines. ${ }^{66}$ Their way of farming was to burn the vegetation on a piece of land and rotate the fields for planting. The slashand-burn style of farming was a typical type of cultivation in Southeast Asia, but the Taiwanese aborigines only planted in small areas, and the fires they built to clear the land were limited in scale. ${ }^{67}$

Before the Dutch arrival, the aborigines planted limited types of crops, vegetables and fruits, such as rice (on dry land), soybeans, sesame, Chinese pearl barley, spring onion, ginger, sweet potato, taro, sugarcane, coconut and Taiwan persimmon. They also kept cats, dogs, pigs and chickens, but did not have ducks, geese, horses, donkeys, cows or sheep. ${ }^{68}$ Although the land was fertile, they did not cultivate more than necessary, and everyday only prepared enough food for the day's consumption. ${ }^{69}$ The closer to the mountain areas the aborigines dwelt, the fewer types of crop they planted. The mountain aborigines did not grow grains, and only had sweet potato and taro. ${ }^{70}$

Land tenure practised by the plains aborigines before outside contact was not recorded. Scholarly attempts to reconstruct their land tenure system before colonisation show that the plains aborigines had land ownership patterns similar to one another, although detailed arrangements varied from group to group. ${ }^{71}$ The villages arranged their settlements in concentric rings, from the inner to the outer: the enclosed village, farmland, hunting and

\footnotetext{
65 See Ming-tu Yang “Going Back into a Future of Simplicity: Taiwan Aborigines' Sustainable Utilization of Natural Resources" in Chia-ju Chang and Scott Slovic (eds) Ecocriticism in Taiwan: Identity, Environment, and the Arts (Lexington, London, 2016) 3-15.

${ }^{66}$ See Chen, above $\mathrm{n} 7$.

67 Yang, above n 65, at 8-9.

${ }^{68}$ Chen, above $\mathrm{n} 7$.

${ }^{69}$ Campbell, above n 9, at 10.

70 See Huang "Fansu liukao", above n 26.

${ }^{71}$ For more details of the reconstruction described in this paragraph, see Shepherd Statecarft and Political Economy on the Taiwan Frontier, above "Introduction" n 35, at 240-242.
} 
fishing grounds, and distant hunting grounds. Within the enclosed village were central areas, shrines and other facilities which were common property, and house sites which belonged to kin groups semi-permanently. Farmlands belonged to kin groups who had exclusive rights of usufruct during each cropping rotation, but the fallow fields belonged to the clan or the village. Hunting and fishing grounds usually belonged to clans or the whole village collectively. Villages also claimed exclusive rights to the outer ring of distant hunting grounds, but the rights might have been difficult to enforce. ${ }^{72}$ It is believed that the plains aborigines recognised property claims by investment of labour in reclaiming the land, thus had the concept of private ownership and owners could alienate their private land to the Chinese. ${ }^{73}$ However it is likely that alienation to people outside the villages, or even the concept of private ownership, was developed after contact with the Chinese. ${ }^{74}$

The mountain aborigines mostly practised collective ownership, although there were variations among different groups. ${ }^{75}$ Village common areas were public land, collectively owned by all members. Ownership of hunting grounds and fishing grounds varied among different aboriginal groups, some belonging to the village as a whole, some the clan, and some the hunting or fishing confederations (lietuan 獵團, yutuan 漁團). ${ }^{76}$ Farmland usually belonged to the clan or kin groups. ${ }^{77}$ Two mountain aboriginal groups, Paiwan and Rukai, practised an ownership system different from the others. In these two groups, all land was owned by the hereditary chiefs, with the exception of the village common areas and facilities, which were collectively owned. ${ }^{78}$

\footnotetext{
72 This could be what was later regarded as "wasteland".

${ }^{73}$ Shepherd, above n 71, at 242.

${ }^{74}$ Since Shepherd used materials from the Qing period and after to reconstruct the land tenure system. See ibid, at 240.

75 See Huang Ying-kuei "Taiwan tuzhuzu de liangzhong shehui leixing jiqi yiyi”" [The two types of Taiwan mountain aboriginal societies and their significance] and Wei Hue-lin "Taiwan tuzhu shehui de buluo zuzhi yu quanwei zhidu" [The tribal organisation and power system in the Taiwanese mountain aboriginal societies] in Huang Ying-kuei (ed) Taiwan tuzhu shehui wenhua yanjiu lunwenji [A collection of research essays on the society and culture of the Taiwanese aborigines] (Lianjing, Taipei, 1986), at 13 and 125-126 respectively.

${ }^{76}$ Huang, ibid. The hunting or fishing organisations could be within the village or across villages. See Wei, ibid, at 121-122.

${ }^{77}$ Huang, ibid, at 13; Wei, ibid, at 125-126.

78 Ibid.
} 
Therefore, the plains aborigines and most mountain aborigine groups practised common ownership of land, and very little private land ownership was recognised.

\section{$B$ Land Tenure under the Dutch}

Although initially the VOC only intended to use Taiwan as an entrepôt, the interaction with and submission of the aborigines tied the Dutch more closely with the land than was initially planned. The VOC required each submitting village to sign a treaty, which specified that the aborigines were to "give [the VOC] the sovereignty over their county",

or "surrender their country and their possession to the States of Holland". ${ }^{79}$ Therefore not only sovereignty, but also property rights, were transferred to the VOC as the representative of the States of Holland. It is questionable how well the aborigines understood the terms and consequences of the treaties, but the presentation of native betel-nut and coconut trees to the Governor as required by the treaty was seen by the Dutch "as a symbol that the sovereignty of their country had now been given to the [United Provinces]". ${ }^{80}$

Under the Dutch administration, the number of Chinese migrants increased and agriculture was developed. The Dutch granted monopoly to Chinese merchants to trade with the aboriginal villages, collected residency-permit tax and trade duty from Chinese residents and traders, but the most important aspects of the Dutch colonisation were licensing Chinese to hunt deer and developing agriculture through Chinese peasants. Licences were issued to Chinese migrants to hunt deer in hunting grounds which were "previously nativecontrolled" or near the aboriginal villages. ${ }^{81}$ The aborigines reacted by attacking the Chinese deer hunters and the violence "nearly always involved tearing or stealing company licences". ${ }^{82}$ It is clear that the aborigines were not only defending their livelihood of deer hunting and deer skin trade, but also guarding their land rights by trying to exclude the outsiders from their traditional hunting grounds.

\footnotetext{
${ }^{79}$ See the treaties recorded in Campbell, above n 9, at 119 and 129.

${ }^{80}$ Tonio Andrade How Taiwan Became Chinese: Dutch, Spanish and Han Colonization in the Seventeenth Century (Columbia University Press, New York, 2008), at 72 quoting a Missionary's letter to the Directors of the Amsterdam Chamber of the VOC, 5 September 1636.

${ }^{81}$ At 136 and 139.

${ }^{82}$ At 140 . For the aboriginal resistance of Chinese hunting on their grounds, see ch 7 .
} 
The Dutch recruited Chinese migrants to reclaim land for farming. Areas were demarcated and noted as "ample and empty" for the Chinese to reclaim and farm. ${ }^{83}$ At the time of Dutch arrival, about 1,500 or more Chinese lived or sojourned in south-western Taiwan. ${ }^{84}$ The Chinese adult male population under the Dutch control increased to about 25,000 in 1650, compared with 68,657 aborigines in the same year. ${ }^{85}$ The Chinese population in Taiwan continued to rise, and reached about 35,000 in $1661{ }^{86}$ By then they had reclaimed just over 10,000 morgen of land for agriculture. ${ }^{87}$ Most of the land was used for growing rice and sugarcane, which together with deer products were the main exports of the VOC. Only a very small portion was for vegetables and other use. ${ }^{88}$ The lands were mostly situated in present day Tainan, especially in and around Tayouan and the nearby villages. ${ }^{89}$

The land tenure adopted by the Dutch is less than clear, and it probably varied in different circumstances. Chinese records show that the Dutch provided seeds, draft oxen and farm implements for the Chinese farmers to work on the land. ${ }^{90}$ Under such an arrangement, the Chinese farmers were tenants of the Dutch, and the land was termed "Crown land" (wangtian 王田 "king's land"). ${ }^{91}$ Although earlier scholars have accepted this view, ${ }^{92}$ recent scholarship has challenged it. Records show that the VOC planned to bestow or had bestowed on the Chinese peasants property rights over the land that they farmed, rights equal to "full ownership rights for them and their descendants". ${ }^{93}$ The recent scholarship

\footnotetext{
${ }^{83}$ At 123.

${ }^{84}$ At 42 and 116. However, Campbell, above n 9, at 8, records that over 10,000 Chinese resided in Tayouan at the time of Dutch arrival.

${ }^{85}$ See Campbell, ibid, at 36; Chuang, above n 16, at 3.

${ }^{86}$ Yang Yan-jie Heju shidai Taiwan shi [The history of Taiwan under Dutch occupation] (Lianjing, Taipei, 2000), at 170. The estimation of the Chinese population differs in differ sources, ranging from 35,000 to 100,000. See Shepherd, above n 71, at 8; Wen-Hsiung Hsu "From Aboriginal Island to Chinese Frontier: The development of Taiwan before 1683" in Knapp (ed), above n 56, 3, at 17; Hung Chien-Chao A History of Taiwan (Cerchio Iniziative Editoriali via Gambalunga, Rimini, 2000), at 18.

${ }^{87}$ Yang, ibid, at 178. Morgen is a unit of measurement of land under the Dutch system, and is understood to be the same size as jia, the measurement unit that was commonly used after the Dutch period.

${ }^{88}$ At $175-177$.

${ }^{89}$ At 180.

${ }^{90}$ See Zhou Xi Zhanghua xianzhi [Gazetteer of Zhanghua County, 1830] (TWWX 156), at 162.

${ }^{91}$ Ibid.

${ }^{92}$ For example Lian Heng Taiwan tongshi [A comprehensive history of Taiwan, 1918] (TWWX 128), at 168; Hsu, above $\mathrm{n} 86$, at 16 and 18.

${ }^{93}$ Governor of Formosa, letter, 11 July 1647, quoted in Andrade, above n 80, at 123. Also see Chiu Hsin-hui The Colonial "Civilizing Process" in Dutch Formosa, 1624-1662 (Brill, Leiden and Boston, 2008), at 152.
} 
has the backing of new information found in the VOC archives. In some aspects it presents the picture more accurately than the earlier understanding which had drawn the conclusion merely from the term "king's land". ${ }^{94}$ However, other indicators posed questions that need to be examined and answered.

Some clues could be found through the Dutch-Zheng transition of administration. Firstly, the Zhengs, even though they recognised private land ownership, took over the "king's land" and managed it as "government land" (guantian 官田). The rent was a percentage of the produce, which percentage was the same as what the peasants had had to pay the VOC. The same category of land became private land during the Qing period, and the land tax rate was less than half of that of the Dutch and Zheng periods. ${ }^{95}$ This suggests that the VOC received the produce as rent, rather than as tax. In other words, the peasants were tenants of the VOC, not private land owners. Secondly, the treaty between the Dutch and the Zhengs after Dutch surrender mentioned a list of debtors and lease-holders, but no list of land owners or land register was mentioned. ${ }^{96}$ Therefore the exact nature of the Chinese peasants' land rights is unclear, and it is possible that private ownership over land was discussed during the Dutch period and was even implemented in some cases, but it had not been implemented systematically or in large scale before the end of the Dutch administration. What is clear is that in some cases the Dutch required the Chinese to pay annual rent to the aboriginal villages, which was collected by the VOC and distributed to the aborigines. ${ }^{97}$

Therefore, it is likely that the Dutch recognised aboriginal land rights to the extent that the land was being occupied and used by the aborigines, such as village sites and farm lands. The Dutch possibly also recognised certain land as aboriginal land when the land was

\footnotetext{
${ }^{94}$ Which itself was a misunderstanding since the Netherlands was a republic at that time.

${ }^{95}$ See Lian, above $\mathrm{n}$ 92, at 188-194, for the various rent and tax rates during the Dutch, Zheng and Qing periods.

${ }^{96}$ Clause VII. See the treaty in Campbell, above $\mathrm{n} \mathrm{9}$, at 455-456. The exact meaning of the term "leaseholders" is not clear - it could mean leaseholders of land, or the merchants who held monopoly trading rights, or both.

${ }^{97}$ Chiu, above n 93, at 152. Also see Kang, above n 15, at 223.
} 
adjacent to the village centre and of which the aborigines had clear control. ${ }^{98}$ The Chinese peasants played a significant role in the Dutch economy, through providing products for exports from their work in both deer hunting and agriculture. For this reason one scholar has argued that the Chinese were co-colonisers with the VOC. ${ }^{99}$

\section{Land Reclamation under the Zhengs}

In some respects the Zheng administration maintained continuity from the Dutch administration. The VOC surrendered all Company property to the Zhengs, including its rights to collect debts and rents. ${ }^{100}$ As mentioned above, the Zheng government continued receiving the same rent for the 10,000 jia "king's land", and called this category of land "government land". The village monopoly and tax system introduced by the Dutch also continued, but with minor alterations. ${ }^{101}$

Chinese migration accelerated during the Zheng period, as did land reclamation. Because of the Zhengs' encouragement, during 1662-1664 six waves of migrants arrived from coastal China to Taiwan. ${ }^{102}$ The Han Chinese population increased by about 70,000 during the Zheng period, to about $120,000 .{ }^{103}$ Settlements extended from south-western Taiwan to many areas of the western and northern low lands. ${ }^{104}$ Land reclamation by officials and migrants was encouraged, and private land ownership was granted over reclaimed land. In total 20,270 jia of private land was reclaimed during the Zheng period. ${ }^{105}$ Most of the areas reclaimed by officials were near the administration centre (in present day Tainan and Gaoxiong), and only one or two were in central western or north-western plains (in present day Jiayi or Taipei). ${ }^{106}$ About 22 major areas were developed into farms by other settlers,

\footnotetext{
${ }^{98}$ Shepherd, above $\mathrm{n} 71$, at 87 also notes that the Dutch recognised some aboriginal land claims but did not recognise the bulk.

99 Tonio Andrade "Pirates, Pelts, and Promises: The Sino-Dutch Colony of Seventeenth-Century Taiwan and the Aboriginal Village of Favorolang" (2005) 64 Journal of Asian Studies 295-321.

${ }^{100}$ Clauses II and VII of the treaty, in Campbell, above n 9, at 455.

${ }^{101}$ See Kang, above n 15, at 271-272.

102 Hung, above n 86, at 59.

103 Shepherd, above $\mathrm{n} 71$, at 96.

${ }^{104}$ Wang, above n 56, at 39.

105 Jiang Yuying Taiwan fuzhi [Gazetteer of Taiwan Prefecture, cir 1689] (Taiwansheng wenxian weiyuanhui, Nantou, 1993), at 80.

106 Song, above n 2, at 46.
} 
16 of which were in present day Jiayi (central western plains), four in Gaoxiong (south), and two in Yunlin (north-western plains). ${ }^{107}$

To provide for the troops, the government also established military colonies, where the soldiers were required to reclaim lands and to farm them for their own upkeep. Lands reclaimed by the soldiers were called "military farms" (yingpantian 營盤田), and there were 40 military farms during the rule of Zheng Jing (1662-1680). ${ }^{108}$ The military farms mostly lay in present day Tainan and Gaoxiong, both in the south of the island. ${ }^{109}$ The total area of military farms is not clear, but it was the "most extensive and systematic" land reclamation during the Zheng period. ${ }^{110}$

From the few records available, the Zhengs respected aboriginal land rights only to the extent of farm lands in active use. Regulations encouraged land enclosure by officials and reclamation by settlers, but strictly forbade encroachment on "land currently cultivated by aborigines and settlers", which seems to be the only restriction on land enclosure and reclamation. ${ }^{111}$ The Zhengs also allocated lands in the aboriginal villages to their officials, ${ }^{112}$ but no record of compensation for taking the land has been found. ${ }^{113}$ The military farms encroached on aboriginal hunting grounds. This caused resentment from the aborigines, and the government had to use armed forces to repress the aborigines' revolts. ${ }^{114}$ Despite this, the relationships between the government and the plains aborigines were said to be "generally peaceful". ${ }^{115}$ The absence of conflict suggests that a mechanism for using the plains aborigines' land might have been in place. Against the mountain aborigines, the government built earthen boundaries, called "earthen oxen" (tuniu土牛),

\footnotetext{
107 At $47-50$.

${ }^{108}$ Hung, above n 86, at 78 .

${ }^{109}$ Song, above n 2, at 43-45.

${ }^{110} \mathrm{Hsu}$, above $\mathrm{n} 86$, at 25 .

111 “不許混圈土民及百姓現耕田地”. See the regulations in Yang Ying Congzheng shilu [Veritable records of Zheng Chenggong's expeditions] (TWWX 32), at 189-190.

112 Ruan Minxi Haishang jianwenlu [Things seen and heard over the seas] (TWWX24), at 39.

113 Shepherd, above n 71, at 94. See Ts'ao Yung-ho Taiwan zaoqi lishi yanjiu [A research on the early history of Taiwan] (Lianjing, Taipei, 1979), 255-293 “Zhengshi shidai zhi Taiwan kenzhi” [The Zhengs' colonisation and land reclamation in Taiwan] for more discussion on the Zheng's colonisation activities in Taiwan.

${ }^{114}$ Shepherd, ibid, at 102; Hung, above n 86, at 78-79.

115 Shepherd, ibid. Also see Ts'ao, above n 113, at 266.
} 
to separate the settlement areas from the mountain areas.$^{116}$ This strategy was adopted by the Qing in later years.

During the brief Zheng era, Chinese settlement increased and spread to further north and further south of the western plains. Agricultural land in Taiwan eventually was divided into areas called bao 堡. During the Zheng period, reclamation of about $80 \%$ of the bao in Anping, $73 \%$ of those in Fengshan, 67\% in Jiayi, 50\% in Danshui and 43\% in Yunlin was started, but each reclaimed area was relatively small, and reclamation of most of the bao was not complete till the Qing period. ${ }^{117}$ Therefore although reclamation was undertaken widely, most parts of the western plains were still occupied by aborigines. This suggests a lack of coordinated or organised reclamation, as the government did not have an overall scheme to systematically reclaim the land other than the military farms.

\section{Land Settlement during the Qing Period}

Chinese settlement continued to expand during the Qing period, but it was limited to the plains areas. After the Zhengs surrendered, the Zheng soldiers and many farmers were repatriated to the mainland, and more left voluntarily. The population dropped sharply. At the time of transition to Qing rule, the government counted 12,724 tax-paying adult males in Taiwan, just over half of the Zheng record of 21,320. ${ }^{118}$ Although the figure of tax paying adult males did not equal the total settler population and was not always a reliable source to calculate the settler population, the extent of decrease indicates the degree of population reduction. Much farmland became waste because of the fall in population. Registered land in 1684 (Kangxi 23) was 18,453 jia, a decrease from a total 30,052 jia of government land and private land in the Zheng record. ${ }^{119}$ The military farms no doubt became derelict with the Zheng army being disbanded and soldiers repatriated to the mainland.

\footnotetext{
${ }^{116}$ Hung, above n 86, at 79.

${ }^{117} \mathrm{Li}$ Ju-ho and Chuang Chin-Teh (eds) Taiwansheng tongzhi [A comprehensive history of Taiwan Province] (Taiwansheng wenxian weiyuanhui, Taizhong, 1972) vol 10, at 119; Chuang Chin-Teh "Qingdai chuqi Taiwan tudi kaifa daoyan" [An introduction to land reclamation in Taiwan during the early Qing period] (1971) 15\&16 Taipei Wen Hsien 166, at 166.

118 Jiang, above n 105, at 77.

119 At 80.
} 
The 18,453 jia of registered land in 1684 included 8,561 jia in Taiwan County, 5,048 jia in Fengshan County and 4,843 jia in Zhuluo County. Population growth and land reclamation activities were slow in the first few years of Qing administration. Zhuluo and Fengshan counties remained so deserted that for 20 years the county magistrates based their offices in the Taiwan County. ${ }^{120}$ In 1685 (Kangxi 24), 2,565 jia of new land was registered, but most of this was very likely to be land already reclaimed under the Zhengs and then registered by Qing officials following annexation. A significant example is that the Fujian Maritime Commander Shi Lang, who had conquered Taiwan and acted as the ambassador to take over Taiwan, owned dozens of estates and was often criticised for land grabbing. ${ }^{121}$ From 1685 to 1702 , newly opened land continued to be registered, ranging from as little as $52 \mathrm{jia}$ in one year to as much as $969 \mathrm{jia}$ in another. It took nearly 40 years for the registered land in the whole prefecture to be brought back to about 30,000 jia, the total recorded land area during the Zheng period. ${ }^{122}$ The slow progress in land reclamation shows the lack of active colonisation.

While land registration indicates a slow increase of newly reclaimed land, travel writings of the Kangxi years show the spread of settlement. In 1697 (Kangxi 36), when Yu Yonghe travelled from the south (Anping) to the north (Danshui), he did not see many Han settlers along the way, and saw no evidence of human activity for about $90 l i$ in the north, from Zhuqian 竹堑 to Nankan 南嵌. ${ }^{123}$ This suggests that there were few, if any, land settlements in the northern part of the western plains in the one or two decades following Qing annexation. By 1713 (Kangxi 52), a travelling officer Ruan Caiwen wrote in a poem that from Banxian, which was about the central point of the western plains, to Zhuqian in the north, "half of the deer hunting grounds have been reclaimed by settlers". ${ }^{24}$ The Gazetteer of Zhuluo County, which was first published in 1717 (Kangxi 56), also recorded that "in the past 30 years, there has been much land reclamation around the county. Deer hunting

\footnotetext{
${ }^{120}$ Inō, above n 48, vol 1, at 179.

121 At 140-141.

${ }^{122}$ See the statistics in Liu, above $n$ 28, at 129-134.

$123 \mathrm{Yu}$, above n 24, at 22.

124 “鹿場半被流民開”. The poem of Ruan, “"Zhuqian”, is recorded in Zhou Zhongxuan Zhuluo xianzhi [Gazetteer of Zhuluo County, 1717] (TWWX141), at 267-8.
} 
grounds turned into farm lands, and deer are few now". ${ }^{125}$ The first Inspecting Censor for Taiwan, Huang Shujing (1722), also noted that "in the past years the foothills were all aborigines' deer grounds. Now the Han reclaimed the land and cultivate it. All one could see are fine farms". ${ }^{126}$

These writings showed the transformation of landscape from aboriginal deer hunting grounds to Han agricultural farms. They pictured a speedy development of land reclamation and provided a contrast to the seemingly slow increase of registered land. Both should be interpreted with caution, and a more or less accurate situation could be discovered through balancing the two types of sources. On the one hand, land registration was not necessarily a reliable source of the actual area of land having been reclaimed, as “hidden land” (yintian 鿵田) was a major problem during the Qing Dynasty, not only in Taiwan, but also across the empire. Hidden land was farm land that should have been, but was not, registered, indicating that the land was reclaimed without a licence or beyond the area specified by the licence. Because of the hidden land problem, the actual area of reclaimed land was usually larger than that was on government register. On the other hand, the travel writings recorded their authors' impression and sentiment, rather than a careful calculation of areas of reclaimed land. For example, Ruan disapproved of the spread of land reclamation, and lamented for the aborigines whose living space was intruded upon or taken over by Han settlers. ${ }^{127}$ Research reveals that what Ruan saw were limited areas in Zhuqian, and the reclamation was small in scale. ${ }^{128}$ Reclamation in Zhuqian was started in about 1711 (Kangxi 50) and advanced during the Yongzheng reign, but much land remained unreclaimed even during the Qianlong years. ${ }^{129}$ The slow pace of land reclamation, the existence of hidden land and the officials' disapproving attitude towards

\footnotetext{
125 Zhou, ibid, at 298, “三十年來附縣開墾者眾，鹿場悉為田”.

${ }^{126}$ Huang, above n 25, at 65, “昔年近山皆為土番鹿場；今則漢人墾種，極目良田”.

${ }^{127}$ Ruan, above n 124, “鵲巢忽爾為鳩居，鵲盡無巢鳩焉徙？”

128 Sheng, above n 2, at 159.

${ }^{129}$ Shih Tien-fu Qingdai Taiwan de diyu shehui: Zhuqian diqu de lishi dili yanjiu [The local society in Qing Taiwan - a research on the historical geography of the Zhuqian area] (Xinzhuxian wenhua ju, Xinzhu, 2001), at $125,233-240$ and 249.
} 
the spread of land settlement evidenced the fact that settlers were more proactive in colonisation than the government and its officials.

During the Kangxi reign, reclamation activities were mainly in Fengshan and Zhuluo counties, including the northern part of Zhuluo which became Zhanghua county in 1722 (Yongzheng 1). ${ }^{130}$ In the Yongzheng era land reclamation expanded north to the Danshui area and to areas in the south of the island. An early Yongzheng period officer noted that "before, Fengshan and Zhuluo were dangerous unhealthy lands, even their county magistrates dared not go there. Nowadays settlers flooded in to as far south as Langqiao and as far north as Danshui and Jilong". ${ }^{131}$ Most of the Taipei basin and the areas of Lower Tamsui (xia Danshui 下淡水) were reclaimed during the Yongzheng reign. ${ }^{132}$ Reclamation of the Taipei basin was completed by 1755 (Qianlong 20), about seven decades after the annexation. Most of the reclamation during the Qianlong years was in the foothills, pressing the mountain areas. ${ }^{133}$ Thus the areas west to the central mountain ranges were mostly reclaimed, but areas over the mountains were little ventured into.

After the Qianlong years, a breakthrough occurred during the Jiaqing reign, when settlers crossed the mountains in the northeast and reclaimed land in Gamalan (present day Yilan). Gamalan is a plains area located in the northeast of Taiwan. About 60-70 li from north to south and about $30 \mathrm{li}$ from east to west, it is surrounded by mountains on all but the east side which faces the sea. ${ }^{134}$ Han settlers reclaimed about 2,400 jia of land over a period of about a decade, which resulted in the establishment of administration by the Jiaqing government in 1811 (Jiaqing 17). Reclamation continued until Gamalan was fully developed into farms.

By 1840 the only unreclaimed lands that were suitable for agriculture, in the eyes of the Qing officials, were strips of land south of Gamalan along the eastern coast, Langqiao in

\footnotetext{
${ }^{130}$ Chuang, above n 117, at 172.

${ }^{131}$ Lan Dingyuan Ping Tai jilüe [Brief accounts of the pacification of Taiwan, 1723] (TWWX 14), at 30.

${ }_{132}$ Peng Yuxin Qingdai tudi kaiken shi [History of land reclamation during the Qing Dynasty] (Nongye, Beijing, 1990), at 247; Chuang, above n 117, at 170.

133 Peng, ibid; Chuang, ibid, at 170 and 172.

${ }^{134}$ Ke Peiyuan Gamalan zhilüe [Brief records of Gamalan, 1837] (TWWX 92), at 177.
} 
the southern tip of Taiwan, and some parts of Puli in central Taiwan, which was surrounded by mountains. ${ }^{135}$ These areas remained largely unreclaimed until the last 20 years of Qing administration, and even in those 20 years the reclamation was limited. By 1888 (Guangxu 14) the newly established Hengchun county in southern Taiwan recorded 4,266 jia of reclaimed land. ${ }^{136}$ No advance seemed to be made after 1888, since in 1892 (Guangxu 18) the area of registered land was smaller than that in 1888, because not only was no new land added to the register, but also some lands were damaged due to flooding and were then removed from the register. ${ }^{137}$ Officials claimed that about 2,000-3,000 jia of land was reclaimed in eastern Taiwan by 1880 (Guangxu 6), but in 1891 (Guangxu 17) registered land area was only 2,255 jia. ${ }^{138}$ Therefore it appears that land reclamation did not advance well in the east or far south.

The status of land settlement by the end of the Qing rule could be seen through Japanese records. The Japanese government investigated arable land to plan for Japanese migration and settlement in 1908 (Meiji 41). What they found to some extent represents the status of land settlement at the end of the Qing administration. In the western plains, 344 areas were found to be suitable for new settlement, with a total area of over 90,000 jia of unreclaimed land. ${ }^{139}$ In eastern Taiwan, the Japanese found 15 suitable areas measuring over 27,000 jia. ${ }^{140}$ The areas in the western plains measured about 261 jia on average, which means that unreclaimed land was fragmented or marginal. Eastern Taiwan consists of a long thin strip of low land, and compared with the west there is not much arable land. However the areas on average measured 1800 jia, which proves that land settlement in eastern Taiwan in the

\footnotetext{
135 See Tai'an huilu jiaji [Taiwan documents collection A] (TWWX 31), at 164 (“Tai'an jiaji”).

$136 \mathrm{Tu}$ Jishan Hengchun xianzhi [Gazetteer of Hengchun County, 1894] (TWWX 75), at 114.

137 At 114 and 118.

${ }^{138} \mathrm{Hu}$ Chuan Taidongzhou caifangce [Draft gazetteer of Taidong Department, cir 1892-1895] (TWWX 81), at 42 .

${ }^{139} \mathrm{Li}$ Wen-liang "Linye zhengli shiye yu dong Taiwan tudi suoyouquan zhi chengli xingtai, 1910-1925" [The forestland investigation project and methods of establishing land ownership in eastern Taiwan, 1910-1925] (1997) 2 Dong Taiwan yanjiu 169, at 171.

140 Ibid.
} 
last 20 years was small scale. This accords with findings from land registration records that reclaimed lands were mostly small and fragmented. ${ }^{141}$

The Japanese findings show that, after over 200 years of Qing administration, although land settlement expanded to the whole western plains and to some areas in the eastern coast, land reclamation did not cover all areas. The view of Qing officials that not much land was left for reclamation, in contrast to the detailed and accurate findings of the Japanese, also shows that the Qing was indifferent to colonisation, while Japan was more industrious and proactive.

\section{$V$ Land Settlement Pattern and Acculturation of Aborigines}

Land settlement shows a pattern of spreading from south-western Taiwan to the whole western plains, and finally to the eastern side of the mountains.

As summarised in Chart 4 and reflected in Chart 5, land settlement started from around the Dutch administration centre of Tayouan, which was renamed but remained the administration centre of successive governments in the next two centuries. Land settlement spread southward and northward in subsequent years. When most of the fertile lands were reclaimed by the end of the Yongzheng reign, reclamation pushed eastward towards the foothills. By the late Qianlong reign, territories west of the central mountains were mostly reclaimed.

Reclamation of Gamalan, in the northeast corner of the island, during the Jiaqing reign was a break-through in that it went over the mountains. After that, not much land settlement was advanced until the last 20 years of the Qing rule of Taiwan. During the Guangxu reign reclamation of the residual areas of arable land commenced, in particular in eastern and southern Taiwan. However the reclamation was late in time and on a small scale.

\footnotetext{
${ }^{141}$ Lin Yu-ju "You yulin tuce kan Qingmo houshan de qingfu shiye yu diquan fenpei xingtai" [The land survey project and the pattern of land rights distribution in eastern Taiwan during the late Qing period as seen from the "fish-scale" land register] (1997) 2 Dong Taiwan yanjiu 131, at 152.
} 
The Han settlements hence started from the administrative centre and pushed outwards to the north, south and east in a pattern resembling ripples. The whole process took over 200 years. The pattern and speed of reclamation testify the lack of organised colonisation or proactive expansion by the government.

Furthermore, as can be seen from Chart 5, more than half of the island was not settled by Han Chinese migrants, despite huge increase in Han population. Throughout the Dutch, Zheng and Qing periods, Han population continued to increase. By 1790 (Qianlong 55), Han population reached nearly 950,000. ${ }^{142}$ By the end of the Qing period, the number increased to about 2.5 million. Nevertheless, Han settlement mostly spread around the coast and in the plains area. The mountain areas and forest remained under the aborigines' occupation and control till the end of Qing administration. This shows that there was a strong constraint on Han settlement. As will be discussed in the next chapter, the Qing government's settlement policies restrained the Han settlement from entering the mountain areas.

Chart 4 Land settlement during the Dutch, Zheng and Qing Periods

\begin{tabular}{|l|l|}
\hline \multicolumn{1}{|c|}{ Period } & \multicolumn{1}{c|}{ Areas of Land Settlement } \\
\hline Dutch (1624-1662) & Near Tayouan in the southwest \\
\hline Zhengs (1662-1683) & Same as above, but small areas scattered along the western plains \\
\hline Qing (1684-1895) & $\begin{array}{l}\text { The plains areas, including those in the west, east and south, but } \\
\text { not all arable land was reclaimed. The mountain areas were not } \\
\text { settled. }\end{array}$ \\
\hline \hline Kangxi (1684-1722) & $\begin{array}{l}\text { Recovering farm lands that were left to waste after Qing } \\
\text { annexation, and enlarging areas that had been reclaimed during } \\
\text { the Zheng period. }\end{array}$ \\
\hline Yongzheng (1723-1735) & Reclamation accelerated and advanced to further south and north. \\
\hline Qianlong (1736-1795) & Western plains mostly reclaimed, and advanced to foothills. \\
\hline Jiaqing (1796-1820) & Gamalan at the northwest corner settled. \\
\hline $\begin{array}{l}\text { Daoguang, Xianfeng, } \\
\text { Tongzhi (1821-1874) }\end{array}$ & $\begin{array}{l}\text { No significant advance, but reclamation of land at the margins of } \\
\text { settlement areas and borders of the mountain territories continued. }\end{array}$ \\
\hline Guangxu (1875-1895) & $\begin{array}{l}\text { Eastern Taiwan, southern Taiwan, and the Puli area in central } \\
\text { Taiwan. }\end{array}$ \\
\hline
\end{tabular}

${ }^{142}$ See Chuang "Qingdai Taiwan tudi kaifa yu zuqun chongtu", above "Introduction" $\mathrm{n}$ 4, at 5. 
Chart 5 Settlement Areas and Direction (Source: Ka Chih-ming (1998), at 15, with added directional indicators)

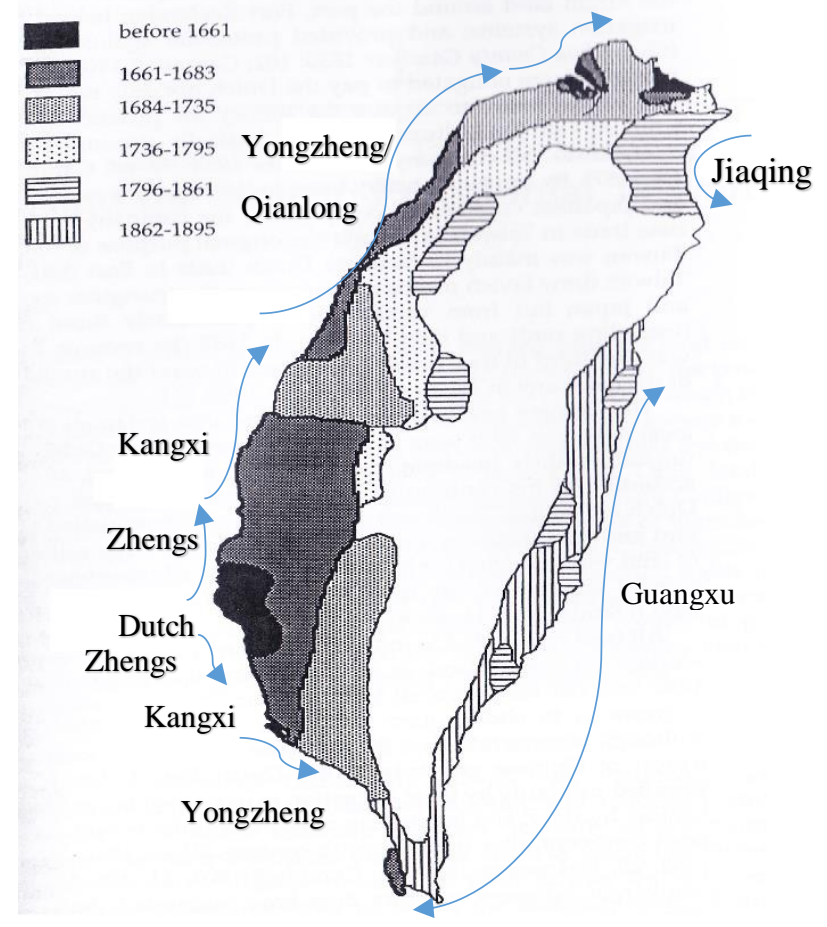

With the spread of Han settlement, aborigines were exposed to Han culture and eventually became acculturated. Chart 6 presents the Qing perspective of Taiwan in 1880 (Guangxu 6), at which time no aboriginal village was marked in the western plains as they had become largely acculturated. In contrast, scattered aboriginal villages along the eastern coast were recorded by Qing officials, as marked on Chart 6. The number of aboriginal villages known to the government increased in later years. The aborigines in eastern Taiwan and in the mountains remained un-acculturated.

The correlation between land settlement and the disappearance of the aboriginal groups' identity shows that land settlement during the Qing period had long-lasting effects on the aborigines. In turn, the land settlement pattern during the Qing period was largely shaped by government policies, as will be demonstrated in the next chapter. 
Chart 6 An 1880 Map of Taiwan (source: Academia Sinica, Taiwan History and Culture in Time and Space: thcts.sinica.edu.tw)

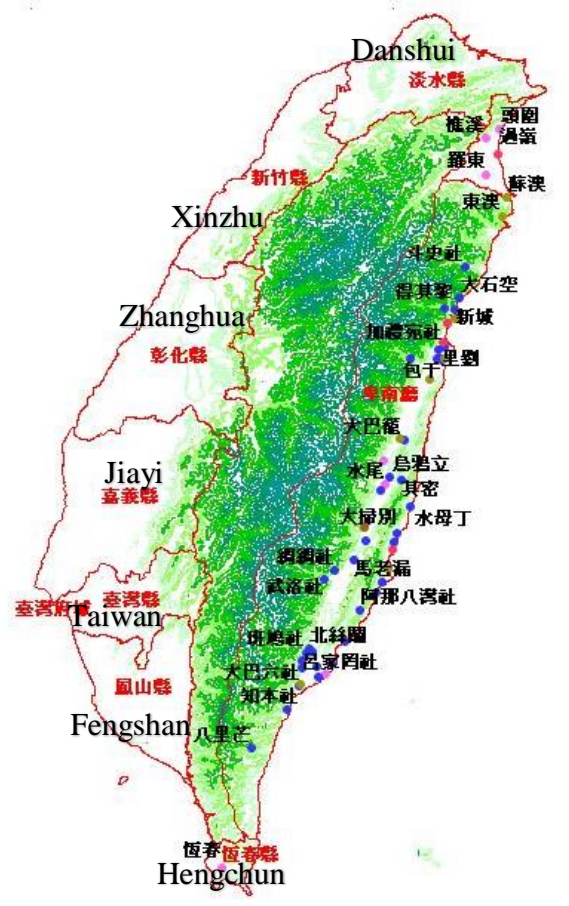




\section{Chapter 2 Qing Settlement Policies in Taiwan}

Chapter 1 demonstrated that for most of the Qing period, land settlement largely occurred in the western plains, and apart from the settlement of Gamalan, it was only after 1875 that there were sizeable settlements by Han Chinese in eastern Taiwan. The mountain areas remained under aboriginal control. This settlement pattern was determined by the settlement policies of the Qing government.

For nearly 200 years the Qing government controlled migration to Taiwan, and formed aboriginal boundaries along the central mountain ranges to segregate the Han settlers and plains aborigines from the mountain aborigines. The government forbade settlement beyond the boundaries and made no attempt to extend government administration over the mountain aboriginal territories, which made up about half of the island of Taiwan. This restrictive stance of the Qing government is referred to in the literature as the "quarantine" (fengjin 封禁) of Taiwan and especially of the mountain aboriginal territories. ${ }^{1}$ This approach came to an abrupt end when the Guangxu government abolished the quarantine policies in 1875 , launched campaigns to "open the mountains and subjugate the aborigines" (kaishan fufan 開山撫番), ${ }^{2}$ and eventually expanded administration over the whole Taiwan.

It is widely accepted that 1875 was the watershed of Qing administration in Taiwan, as is suggested by an apparently abrupt change from a quarantine policy to expansion. However, despite some comprehensive studies on the Qing administration in Taiwan, there has been little analysis of the policy rationales during 1800-1875, or of a comparison of the policy rationales for the periods before and after 1875 .

\footnotetext{
${ }^{1}$ Shepherd is the first to use the term "quarantine" to describe the Qing's restriction of migration to Taiwan and forbiddance of settlement in the mountain areas, and to contrast it with "colonisation". The term is used throughout in Shepherd Statecarft and Political Economy on the Taiwan Frontier, above "Introduction" n 35. For example, the title of Part II is "Ch'ing Quarantine Policies and the Spread of Han Settlement".

${ }^{2}$ Kaishan fufan is usually translated as "open the mountains and pacify the aborigines", but "pacify" implies the use of military force, while the word fu means to bring to surrender, usually by offering rewards. Since the Qing government used both $f u$ and jiao 剿, which is to send armed forces to suppress an opposing force, to bring the aborigines under control, "subjugate" seems to be the more appropriate term to describe the campaigns.
} 
This chapter examines the Qing government's settlement and land reclamation policies in Taiwan and analyses the rationale that underpinned these policies. Part I describes the Qing Empire and its administrative and legal systems. This will inform discussions in this and later chapters. Parts II to IV examine Qing policies at different stages. Part II discusses the policies during the Kangxi, Yongzheng and Qianlong reigns (1684-1795), when the government generally discouraged or tried to prevent migration to and settlement in Taiwan. Part III analyses policy-making during 1795-1875, when Gamalan was settled and the government debated whether to open up inner Shuishalian 水沙連 for settlement. In this Part it is argued that, since the early 1800s, the Qing government and officials displayed an attitude that was different from that in the 1700s. Contrary to the common belief that Qing policies changed abruptly in 1875, this Part shows that the period between 1795 and 1875 was in fact a transitional stage in terms of settlement policies concerning Taiwan. Part IV examines the "opening the mountains and subjugating the aborigines" campaigns after 1875. Parts II to IV demonstrate that security was at all times the paramount consideration in Qing policy-making. Part V discusses the overall policy trend against the background of Qing policies on other frontiers, and analyses the effects of Confucian legal thought and the Chinese imperial constitutional arrangements on the formation of policy. This chapter concludes that the policy trends for Taiwan fitted with Qing policy shifts in other frontier areas such as the inner Asian regions (Manchuria, Mongolia and Xinjiang) and southwest China. The central rationale had always been to ensure the security of the regime and social stability, and this was determined in turn by Qing legal traditions.

\section{Qing Administrative and Legal Systems}

The Qing Empire was "one of the largest and longest-lived multinational empires of the early modern world". ${ }^{3}$ The empire was created by the Manchus and originated in northeast China, known as Manchuria.

\footnotetext{
${ }^{3}$ R Kent Guy “Who were the Manchus? A Review Essay” (2002) 61(1) Journal of Asian Studies 151, at 151.
} 


\section{A Brief Accounts of Qing History}

The Manchus belonged to the ethnic group known as Jurchen. Jurchen is a name that emerged in the early $10^{\text {th }}$ century, although the people possibly dated back to the $6^{\text {th }}$ century BC. ${ }^{4}$ The Jurchen people were seen by the Chinese during the Ming Dynasty as "wild people" (yeren 野人), who practised hunting and gathering, and used Chinese and Korean slaves whom they captured at the borders to engage in agriculture. ${ }^{5}$ Some Jurchen chiefs acknowledged Ming suzerainty, as well as having interaction with Korea and the Mongols. One of the three major Jurchen groups, the Jianzhou 建州 Jurchen confederation, grew in power under Nurhaci (1559-1626), the forefather of the Qing rulers. ${ }^{6}$ In 1616 Nurhaci ascended to the throne and declared his reign to be "Heavenly Mandated" (tianming 天命), a title after the Chinese fashion. ${ }^{7}$ This signified independence from the Ming. The term "Manchu" appeared during Nurhaci's time, but it was formally adopted only in $1635 .{ }^{8}$ In 1636 Nurhaci's son Hung Taiji (r 1626-1643) announced a new name, "Qing”, for the Manchu entity, and thus started the Qing Dynasty. The Manchus' sinicisation process started during Nurhaci's time, when Nurhaci recruited Chinese scholars to translate Chinese literature and the Ming laws. By 1638, the Qing Court completed the central bureaucracy on the Ming model, and adopted Ming laws with some adjustments. ${ }^{9}$

Qing forces entered Beijing in 1644, and in subsequent decades the Qing defeated remnant Ming resistance forces and consolidated their rule over the rest of China. ${ }^{10}$ The Shunzhi government conquered northern China and lower Yangtze valley before taking control of the south and west of China. ${ }^{11}$ The Kangxi government pacified the rebellion of the Three

${ }^{4} \mathrm{Li}$ "State Building before 1644", above ch $1 \mathrm{n}$ 60, at 10.

5 At 10 and 21. Nicola Di Cosmo "The Extension of Ch'ing Rule over Mongolia, Sinkiang, and Tibet, 16361800" in Willard J Peterson (ed) The Cambridge History of China Volume 9: The Ch'ing Dynasty to 1800 Part Two (Cambridge University Press, Cambridge, 2016) 111, at 112, notes that only one of the three major Jurchen groups was called yeren.

${ }^{6} \mathrm{Li}$, ibid, at 11-51.On Nurhaci, see also Frederick W Mote Imperial China 900-1800 (Harvard University Press, Cambridge (Mass), 1999), at 786-790.

${ }^{7} \mathrm{Li}$, ibid, at 37.

${ }^{8}$ At 27.

${ }^{9}$ At 35 and 60-61. Also see Zhang Qingchao fazhishi, above "Introduction" n 30, at 22.

${ }^{10}$ See Mote, above n 6, at 801-810.

11 See Dennerline “The Shun-chih Reign”, above ch 1 n 60, at 83-97; Mote, ibid, at 821-824. 
Feudatories (sanfan 三藩) in southern China, ${ }^{12}$ defeated the Zhengs and annexed Taiwan, settled borders with Russia in the northeast and launched military campaigns in the northwest. ${ }^{13}$ The Kangxi, Yongzheng and Qianlong reigns have been seen as the golden age of the Qing Dynasty, when the empire continued to expand and consolidate its control. By the 1750s, the Qing Court controlled Mongolia, Xinjiang and Tibet, in addition to China proper, Manchuria, Taiwan and southwest China. ${ }^{14}$

During the late Qianlong reign the dynasty started to decline because of successive rebellions, followed by foreign threats in the first half of the $19^{\text {th }}$ century. In 1840 the first Opium War with Britain was fought and lost, and subsequently the Qing government was forced to open treaty ports for trade after signing a series of treaties with Britain, France, the United States and Russia. ${ }^{15}$ In 1895 Taiwan was ceded to Japan, and in 1912 the Qing Court was overthrown by the Republic of China, thus ending the last dynasty in Chinese history.

Being an ethnic minority ruler over China, the Qing Court had two foundations for its rule - "neo-Confucian legitimacy" and "ethnic sovereignty". That is, the Qing embraced Confucian culture and political norms on the one hand, and retained Manchu identity and culture on the other. ${ }^{16}$ The early to mid-Qing government particularly showed "zealous adherence" to Confucian values. ${ }^{17}$ Confucian norms underpinned the Qing legal tradition, while the unique Manchu identity adjusted the legal system where necessary. An example of the adjustment was the creation of the Board for Governing Outer Territories (Lifanyuan

\footnotetext{
12 The Three Feudatories were three highly autonomous Han generals who were rewarded with large domains for their service during the course of Qing conquest.

${ }^{13}$ See Jonathan D Spence "The K'ang-hsi Reign” in Peterson (ed) The Cambridge History of China Volume 9, above ch 1 n 60, 120, at 136-156.

${ }^{14}$ See Peter C Perdue China Marches West: The Qing Conquest of Central Eurasia (Harvard University Press, Cambridge (Mass), 2005) for an analysis of Qing expansion in the north-western territories.

${ }^{15}$ See John K Fairbank (ed) The Cambridge History of China Volume 10: Late Ch'ing 1800-1911 Part One (Cambridge University Press, Cambridge, 1978), in particular ch 3, Susan Mann Jones and Philip A Kuhn "Dynastic Decline and the Roots of Rebellion" 107-162; and ch 5, John K Fairbank "The Creation of the Treaty System" 213-263.

${ }^{16}$ Elliott The Manchu Way, above "Introduction" n 28, at 13.

17 William T Rowe "Social Stability and Social Change" in Peterson (ed), above n 13, 473, at 562.
} 
理藩院), to govern Mongolia, Xinjiang and Tibet, ${ }^{18}$ and the implementation of dual legal systems in those areas. ${ }^{19}$ A unique feature of Qing organisation was the banner system. The Manchu rulers divided all Manchus into eight banners, which initially was a form of organising the fighting force but eventually became a way of organising Manchu society. The bannermen enjoyed privileged status, and the banner system helped to preserve Manchu identity. ${ }^{20}$ However in general the Qing administrative and legal systems were largely Chinese in character, and followed long-established Chinese precedents.

\section{B Qing Administrative System}

The Qing administrative structure was largely inherited from the preceding Ming Dynasty. In the central government, six ministries administered six areas of national affairs. The Ministry of Households ( $h u b u$ 户部) was responsible for taxes and revenues, as well as regulation of other civil matters such as marriages and inheritance, ${ }^{21}$ the Ministry of Justice ( $x$ ing $b u$ 刑部) for criminal law matters; the Ministry of Personnel (libu 吏部) for official appointments; the Ministry of Works (gongbu 工部) for construction matters; the Ministry of War (bingbu 兵部) for military affairs; and the Ministry of Rites (libu 禮部) for ceremonies, including the reception of foreign guests. ${ }^{22}$ At the local government level, the Qing divided its empire into provinces (sheng 省), provinces into prefectures ( $f u$ 府), and prefectures into counties (xian 縣) and sometimes sub-prefectures (ting 廳). A Governor headed each province, and a Governor-General oversaw or coordinated the administration

\footnotetext{
${ }^{18}$ Xiao Yishan Qingdai tongshi [Comprehensive history of the Qing Dynasty] (Shangwu, Taipei, 1963), at 503, 525, 547-558. Lifanyuan has traditionally been translated as "the Court of Colonial Affairs". Di Cosmo, above n 5, at 123-124, argues that "the Board for Governing Outer Territories" is a more appropriate translation.

${ }^{19}$ See Dorothea Heuschert "Legal Pluralism in the Qing Empire: Manchu Legislation for the Mongols" (1998) 20 International History Review 310-324; Tian Huan "Governing Imperial Border: Insights from the Study of the Implementation of Law in Qing Xinjiang” (PhD diss, Columbia University, 2012).

${ }^{20}$ The central argument of Elliott, above $\mathrm{n} 16$.

${ }^{21}$ Charles O Hucker A Dictionary of Official Titles in Imperial China (Stanford University Press, Stanford, 1985) translates hubu as Ministry of Revenue. Although tax and revenues were the major function of the Ministry, given that the Ministry also regulated other household matters, and the character $h u$ f means household, it is felt that "Ministry of Households" is more appropriate.

${ }^{22}$ See Xiao, above $\mathrm{n} \mathrm{18}$, for a comprehensive examination of the Qing decision-making bodies and administrative departments.
} 
of two or three provinces. Governors and Governors-General reported directly to the Emperor, and served as the channel between local and central government. ${ }^{23}$

Taiwan was incorporated as a prefecture under Fujian province. The Taiwan Prefect was the civil head of the prefecture, while the Regional Commander (zongbing 總兵) was the military head. A special Taiwan-Xiamen Military Defence Circuit Intendant (Fenxun Taiwan-Xiamen bingbeidao 分巡臺灣廈門兵備道), later changed to Taiwan Circuit Intendant, oversaw the civil and military affairs of Taiwan. The Circuit Intendant was subordinate to the Governor, although they were given direct access to the emperors from 1788 (Qianlong 53) on. ${ }^{24}$ Each County was headed by a magistrate. The process for appointing officials to Taiwan followed the regular process, but officials were appointed for a term of no more than three years to avoid their gathering too much power in the former base of opposition.

\section{Qing Legal System}

The Qing legal system also largely followed the traditional Chinese style. Underpinning the Chinese legal tradition were Confucian norms, which emphasised li (禮 "rite", "propriety") as the governing force of human behaviour. ${ }^{25}$ The formal law governed only criminal and administrative matters, and $l i$ as the "moral law" and "customary, un-codified law" governed other aspects of society. ${ }^{26}$ This meant that there was little distinction between law and social norms. The formal law had an authoritarian structure and a public character, as it was "primarily directed not to the people, but to administrative officials". ${ }^{27}$

\footnotetext{
23 At 524-542. Also see R Kent Guy Qing Governors and Their Provinces: the evolution of territorial administration in China, 1644-1796 (University of Washington Press, Seattle, 2010).

${ }^{24}$ Qing Gaozong shilu xuanji [Selected veritable records of the Qianlong Emperor] (TWWX 186), at 613 ("Gaozong shilu”). See Lian Taiwan tongshi, above ch 1 n 92, at 145-150 and 337 for the civil and military hierarchy and positions in Taiwan.

${ }^{25}$ See Glenn Legal Traditions of the World, above "Introduction" n 9, ch 9, in particular at 326-339 for a discussion of Confucian ways and $l i$.

${ }^{26}$ At 326-328; Yang Jingfan et al (eds) Zhongguo falü sixiangshi jianbian [A brief history of Chinese legal thoughts] (Guangxi shifan daxue, Guilin, 1988), at 7-8; Derk Bodde and Clarence Morris Law in Imperial China: Exemplified by 190 Ch'ing Dynasty Cases (Harvard University Press, Cambridge (Mass), 1967), at 5.

${ }^{27}$ Glenn, ibid, at 322; Hyung I Kim Fundamental Legal Concepts of China and the West: A comparative study (Kennikat Press, New York, 1981), at 117.
} 
Criminal law guided officials in adjudicating cases, and administrative law regulated officials' behaviour. Reflecting this Chinese legal tradition, the major Qing legislation was the Great Qing Code (Daqing lï 大清律) and the Great Qing Institutes (Daqing huidian 大清會典), constituting a criminal law code and an administrative law code respectively. Both codes were based on Ming Dynasty models and were relatively stable. ${ }^{28}$

Other than the law codes, $l i$ (例 literally "precedents", in effect regulations) was the most important form of legislation. ${ }^{29}$ Although understood to be subordinate legislation, $l i$ had the same legal status as law codes, and they were revised regularly. ${ }^{30}$ Two sets of important regulations were the Imperially Approved Precedents to the Great Qing Institutes (Qinding Daqing huidian shili 欽定大清會典事例) and the Regulations of the Six Ministries (Liubu $z$ zeli 六部則例). ${ }^{31}$ These regulation series were made up of single-entry stand-alone regulations, which were made at different times to address specific issues. Typically officials raised issues and made recommendations on certain matters, and the Emperor would refer important recommendations for discussion by the Grand Council (Junjichu 軍 機處) or central government officials. ${ }^{32}$ Important recommendations were made into regulations after imperial approval.

Imperial decrees, and the Emperor's endorsement or annotation on the official memorials which made the original recommendations, were not recorded in formal regulation books, and probably should be classified as policies. However, the Confucian legal tradition emphasised the authority of the Emperor, who enjoyed legislative, executive and judicial powers in one person. ${ }^{33}$ Because of this absolute authority of the Emperor and because laws were directed at officials, in reality anything the Emperor pronounced became enforceable by officials, and had the effect of law. Therefore there was little distinction between law

\footnotetext{
${ }^{28}$ See Zhang, above n 9, at 165-168.

${ }^{29}$ At 170 .

30 Ibid.

31 At 165-181.

32 J K Fairbank and S Y Teng "On the Types and Uses of Ch'ing Documents" (1940) 5 Harvard Journal of Asiatic Studies 1-71 discusses the process of dealing with official memorials and recommendations in the central government.

${ }^{33}$ Yang et al (eds), above n 26, at 24.
} 
and policy. Further, decrees and notices issued by local officials also had the effect of law within the jurisdiction of the issuing officials.

Given the lack of distinction between law and policy, Qing laws and policies towards land settlement in Taiwan at various stages were manifested in regulations, imperial decrees, official recommendations and in administrative action.

\section{Controlling Settlement}

Over the century of the Kangxi, Yongzheng and Qianlong reigns, the government deliberately restricted land settlement and government administration in Taiwan. This was achieved mainly through controlling migration and segregating settlers and the aborigines.

\section{A Annexation and Administrative Structure}

\section{The Kangxi era}

The Qing Court was not interested in acquiring an overseas territory. The purpose of the attack on the Zhengs in Taiwan was to quash the last Ming stronghold and to eliminate an enemy, ${ }^{34}$ and the annexation after the Zhengs' surrender was primarily the result of security considerations.

After the Zhengs surrendered, one option of the government was to withdraw all Chinese subjects and abandon the island. ${ }^{35}$ However, the then Fujian Maritime Commander Shi Lang, who had led the successful expedition to Taiwan, argued for the retention of the island on the basis of defence and security. Shi argued that Taiwan was the shield for the coastal provinces; if abandoned, it could become a bandits' lair or be re-occupied by the "red-hair" (the Dutch), and thus could threaten the empire's security. ${ }^{36}$ Recognising that

\footnotetext{
${ }^{34}$ See the Kangxi Emperor's comments in Qing Shengzu shilu xuanji [Selected veritable records of the Kangxi Emperor] (TWWX 165), at 129 (“Shengzu shilu”), “臺灣屬海外地方, 因從未向化, 肆行騷擾, 演 海居民迄無寧日, 故興師進繳”。

${ }^{35}$ Lian, above n 24, at 59.

${ }^{36}$ Shi Lang "Gongchen Taiwan qiliu shu" [Some humble opinions on whether to retain or abandon Taiwan] in Shi Lang Jinghai jishi [Records of pacifying the seas] (TWWX 13), at 60-61.
} 
Taiwan was strategically important, the Kangxi Emperor adopted Shi Lang's view and formally annexed Taiwan in $1684 .^{37}$

The fact that no consideration was given to Taiwan apart from for security was illustrated clearly in the administrative system in Taiwan. Military forces of 8,000 soldiers were placed to guard important ports. ${ }^{38}$ In contrast, civil administration was maintained at a minimum level with few changes from the Zheng period, and by a handful of civil officials. As discussed in Chapter 1, the Kangxi government maintained the Zhengs' administrative structure in Taiwan, that is, a prefecture with two counties, and added only one county at the prefecture capital (see Chart 7A). Nominally the three counties, Taiwan, Fengshan and Zhuluo, covered the whole western plains. In reality administration did not effectively extend to all parts of the territory, and settlers needed a government permit to go beyond Dajia River at about the mid-point of the western plains. ${ }^{39}$

The Kangxi Emperor was not interested in colonisation of Taiwan. When the FujianZhejiang Governor-General made recommendations encouraging land reclamation in Taiwan in 1715 (Kangxi 54), the Emperor was reluctant to approve the recommendation and expressed the view that to encourage land reclamation in Taiwan was short-sighted, as this would only cause major trouble in the future. ${ }^{40}$ By major trouble, the Emperor certainly had in mind conflicts and instability in Taiwan. This attitude of the Emperor partly accounted for the insignificant advance of land settlement during the Kangxi era, as discussed in Chapter 1.

\footnotetext{
${ }^{37}$ Shengzu shilu, above n 34, at 131.

${ }^{38}$ At 165.

${ }^{39}$ Huang Taihai shichalu, above ch 1 n 25, at 134.

40 “㗌灣地方多開田地, 多聚人民, 不過目前之計而已。將來福建無窮之害, 俱從此生”. See the Kangxi Emperor's rescript in Ming Qing dang'an, above “Introduction” n 55, vol 9, at 308-309.
} 


\section{The Yongzheng era}

The Yongzheng government has often been seen as pro-colonisation, mainly because of its administrative expansion. ${ }^{41}$ However the central consideration remained security, and the existing policies largely remained in place.

In the first year of the Yongzheng reign, Zhuluo County was subdivided to create a new county, Zhanghua, above the middle point of the western plains. In addition, a Danshui Sub-prefect was posted in the north. This change effectively extended government control from the southwest to the far north (Chart 7B). Although this has been seen as expanding Qing territory, the government's intention was not colonisation. Before the subdivision, Zhuluo County covered a vast territory that extended "east to the mountain ranges, west to the sea, south to Fengshan Country, south-west to Taiwan Country, and north to the Jilong Mountain [in the far north]" ${ }^{42}$ From the south to north it extended $919 l i,{ }^{43}$ and the total area was more than three times larger than the second largest county Fengshan. ${ }^{44}$ Despite the restriction on going beyond Dajia River during the Kangxi reign, illegal crossing and unauthorised land reclamation in the northern part of Zhuluo County had continued to occur. To tighten control on law and order in the north, and to eliminate security risks, as early as 1717 (Kangxi 56), the Zhuluo County magistrate had recommended subdivision of the County, arguing that the district was too vast to be effectively controlled, which allowed the disorderly to hide from the law. ${ }^{45}$

The government finally decided to strengthen control in the north after a major settler uprising, the Zhu Yigui uprising, broke out in 1721 (Kangxi 60). An Inspecting Censor for Taiwan repeated the recommendation of subdividing Zhuluo in 1723 and this was accepted by the Court. ${ }^{46}$

\footnotetext{
${ }^{41}$ For example, see Shepherd, above n 1, at 195 and 236. Another reason for seeing the Yongzheng government as pro-colonisation is because of its policies on land reclamation, but this point will be discussed in ch 3.

${ }^{42}$ Zhou Zhuluo xianzhi, above ch $1 \mathrm{n} \mathrm{124, \text {at } 5 .}$

${ }^{43}$ At 6.

${ }^{44}$ Chen Wenda Fengshan xianzhi [Gazetteer of Fengshan County, 1719] (TWWX 124), at 15.

${ }^{45}$ Zhou, above n 42, at 50.

${ }^{46}$ Qing Shizong shilu xuanji [Selected veritable records of the Yongzheng Emperor] (TWWX167), at 3-4 (“Shizong shilu”).
} 
Lan Dingyuan, an advisor to the Fujian Maritime Commander who led troops to suppress the uprising, advocated expansion and land reclamation. Lan's standpoint was founded on military strategy and on combating attacks by the mountain aborigines. Lan argued that in order to reduce trouble caused by aborigines, it was better to fill the land with settlers and have the land developed into agricultural land. This would in turn expose the aborigines to Han culture and transform them into the Empire's subjects. ${ }^{47}$ Security was therefore the determining factor for Lan's advocacy, as well as the Yongzheng government's expansion.

Chart 7 Administrative Control during the Kangxi and Yongzheng Reigns (Source: Academia Sinica, Taiwan History and Culture in Time and Space)
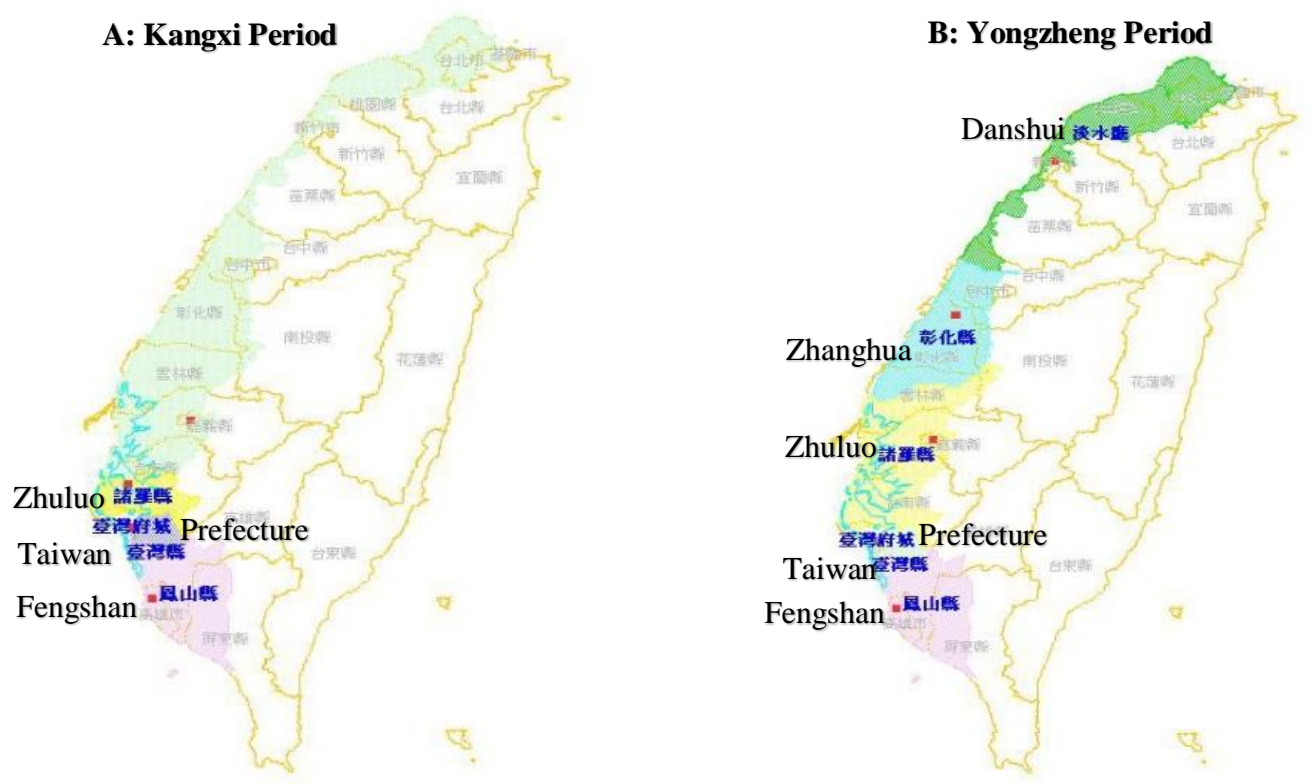

\section{The Qianlong era}

The administrative structure as adjusted by the Yongzheng government remained unchanged during the Qianlong reign, and scholars have seen the Qianlong era as reversing from the Yongzheng government's "pro-colonisation" approach. ${ }^{48}$ In fact, while the

\footnotetext{
${ }^{47}$ See Lan Ping Tai jilüe, above ch 1 n 131, in particular at 30-32, 56 and 69; Lan Dingyuan Dongzheng ji [Collection of records of the eastern expedition, 1732] (TWWX 12), in particular at 60 and 87.

${ }^{48}$ For example, Shepherd, above n 1, at 151 and 236.
} 
emperors might have different views on how to maintain effective governance of Taiwan, the ultimate objective of security remained the same.

Like the Kangxi Emperor, the Qianlong Emperor was concerned that Chinese land settlement could cause disturbances on the island. When officials recommended allowing settlers to reclaim land in Taiwan in 1744 (Qianlong 9), the Qianlong Emperor dismissed the recommendations and reasoned that the government "should not ... seek trivial benefit and encourage land reclamation", lest trouble would ensue. ${ }^{49}$ This was despite the fact that since the Yongzheng era Taiwan had become the granary of Fujian Province and regularly exported rice to relieve the food shortages there.$^{50}$ However, at the outbreak of another major Han uprising in Taiwan, the Lin Shuangwen uprising, in 1786 (Qianlong 51), the Emperor saw wisdom in Lan's strategy. The Emperor agreed with Lan that leaving fertile lands to the non-acculturated aborigines, who did not cultivate them, only attracted settlers to reclaim them illegally, resulting in conflicts and trouble. ${ }^{51}$ The Emperor repeatedly emphasised to his officials that Taiwan was the "important coastal frontier territory" (haijiang zhongdi 海疆重地) and “the important fence line of the five [coastal] provinces" (wusheng fanli zhongdi 五省藩篗重地). ${ }^{52}$

Therefore, in the first century of Qing administration of Taiwan, the only expansion occurred during the Yongzheng reign. No matter whether to expand or to restrict settlement and limit government control, the policy rationale was security and social stability.

\section{Administration of aborigines}

The Qing government made little efforts to administer the aborigines. The government rarely tried to subjugate the aborigines or to impose cultural change.

\footnotetext{
49 “不應聽奸匪之浮言，圖目前之微利，遽議召[招]墾; 或致將來別生事端，甚有關係。”Gaozong shilu, above n 24, at 39 .

${ }^{50}$ In 1729, the Yongzheng government decided to transfer 49,000 shi of grains from Taiwan to Fujian, and this was made a precedent to be followed in later years. See Shizong shilu, above n 46, at 28. Also see John Robert Shepherd "Taiwan Prefecture in the Eighteenth Century" in Peterson (ed), above n 5, 77, at 101-102.

${ }^{51}$ Gaozong shilu, above n 24, at 401-402.

${ }^{52}$ For example, ibid, at 38.
} 
Qing officials classified the aborigines into two general types - acculturated aborigines (shufan 熟番) and non-acculturated aborigines (shengfan 生番), according to the level of acculturation. ${ }^{53}$ The concepts of $s h u$ and sheng were used by earlier Chinese dynasties to classify different groups of less developed ethnic peoples in mainland China. "Sheng" is a word to describe uncooked food, un-worked land, un-ripened fruit, unskilful hands, or strangers. "Shu" is the opposite of "Sheng". ${ }^{54}$ To the Qing officials, shufan were those that paid tax, performed corvée and to some degree adopted Han Chinese culture. ${ }^{55}$ Shengfan that submitted to the Qing rule paid a token tax, were exempted from corvée, and were left to continue with their old ways of living. ${ }^{56}$ This type of shengfan was called guihua shengfan (歸化生番“submitted non-acculturated aborigines”) or huafan 化番 for short. The concepts of "shu" and "sheng" aborigines were evolving, as the "sheng" eventually became more acculturated, and gradually transformed to "shu".

At the time of the Qing annexation, in total 46 aboriginal villages were subject to the Qing administration - 12 in Fengshan and 34 in Zhuluo. ${ }^{57}$ These are likely to have been inherited from the Zheng regime. The Kangxi government was not interested in changing the status quo in Taiwan, and there is no record of the government trying to subjugate the aborigines, although some aboriginal villages submitted themselves to the Qing government. ${ }^{58}$ In the case of submitted aborigines, the government was happy to charge only a token tax and to otherwise leave them in the state they were, without any disturbance or additional administration. ${ }^{59}$ During the Yongzheng reign, the Taiwan Regional Commander, Lin

\footnotetext{
${ }^{53}$ There are a few possible translations for shufan and shengfan, and the most commonly used translations are "cooked aborigines" and "raw aborigines" respectively. See Magnus Fiskesjö "On the 'Raw' and the "Cooked" Barbarians of Imperial China" (1999) 1 Inner Asia 139 for a discussion of the use of "raw" and "cooked". In this thesis, shufan is referred to as "acculturated aborigines", and shengfan "non-acculturated aborigines".

${ }^{54}$ Teng Taiwan's Imagined Geography, above "Introduction" n 14, at 123, explains it this way: "Sheng and shu express a host of binary concepts, not only raw and cooked, but also unripe and ripe, unworked and worked (as metal or stone), wild and tamed, unplowed and plowed, strange and familiar".

${ }^{55}$ Liu Chongxiu Fujian Taiwan fuzhi, above ch 1 n 28, at 101.

${ }^{56} \mathrm{Ibid}$, at 517; Shengzu shilu, above n 34, at 162.

${ }^{57}$ Gao Gongqian Taiwan fuzhi [Gazetteer of Taiwan Prefecture, 1694] (TWWX 65), at 5-6.

${ }^{58}$ For example, in 1693 (Kangxi 32), six aboriginal villages in Zhuluo County submitted. In 1716, 10 villages in the south and 5 in the north submitted. See Liu, above n 55, at 516-517.

${ }^{59}$ Ibid. The 10 southern villages had 1385 people and the five northern villages had 3368 people. The tribute was 50 deer skins each year from each of the south and the north clusters.
} 
Liang, encouraged and enticed aboriginal submission, resulting in the submission of 108 aboriginal villages during the 13 years of the Yongzheng reign. ${ }^{60}$ The Qianlong government preferred not to encourage submission of the aborigines, ${ }^{61}$ but as Han settlements expanded, submission of aborigines continued.

In the early Qianlong reign, local officers identified at least 299 aboriginal villages by their names. ${ }^{62}$ Records show that 93 aboriginal villages paid village tax (shexiang 社饷) and 61 aboriginal villages paid token tax. ${ }^{63}$ The 93 villages were seen as acculturated aborigines by the government. The classification seemed to stabilise after that, and the number of recognised acculturated aborigines remained at 93 till the end of the Qing period.

In 1766 (Qianlong 31), the government appointed two aboriginal sub-prefects (lifan tongzhi 理番同知) to deal with aboriginal affairs, with a focus on the plains aborigines. To those mountain aborigines, the government was content to keep them out of the settlement areas through building aboriginal boundaries. To a great extent, the aborigines, especially the mountain aborigines, were protected by the government's migration control and segregation policies, which reduced the impacts of settlers on the aborigines.

\section{B Migration control}

By means of a permit system, the government controlled the number and types of people to enter Taiwan.

The first recorded regulation on the subject of the permit system was made in 1712 (Kangxi 51), but evidence suggests that it was introduced before 1711, probably soon after formal annexation in $1684 .{ }^{64}$ There were two main considerations for a permit system. The first

\footnotetext{
${ }^{60}$ Lan Dingyuan Luzhou chuji [First collection of Lan Dingyuan's writings], vol 8 (Chinese Text Project www.ctext.org).

${ }^{61}$ See the Emperor's comment in 1737 in Gaozong shilu, above n 24, at 8, “嗣后各社生番似應聽其自便, 嚴飭通事等不必誘其來歸，致啓日後需端”。

${ }^{62}$ See Fan Chongxiu Taiwan fuzhi, above ch 1 n 29, at 69-73.

${ }^{63}$ See Liu, above n 55, at 191-192.

${ }^{64}$ See Qing huidian Taiwan shili [Great Qing Institutes, precedents concerning Taiwan] (TWWX 226), at 30, for the regulation ("Taiwan shili"). A report dated 1711 (Kangxi 50), by Zhou Yuanwen (Taiwan Prefect 1707-1711), indicated that policing of illegal crossing without a permit had been reiterated by the authorities a few times. See Zhou Yuanwen Chongxiu Taiwan fuzhi [Revised gazetteer of Taiwan Prefecture, 1718]
} 
consideration was to reduce pressure on land; the rationale being that Taiwan was not able to support too large a population which could lead to conflict. ${ }^{65}$ Therefore regulations forbade migrants to bring families with them. The second, and the more important consideration, was to prevent unruly persons from entering Taiwan, thus threatening the stability of the society. To this end, officials often recommended that only those who had property in mainland China or those who had relatives in Taiwan were allowed to enter Taiwan. ${ }^{66}$ A Taiwan Prefect in 1729 (Yongzheng 7) argued that "the migration of good subjects” (liangmin zhi du 良民之渡) “definitely should not be forbidden” (bi buke jin 必 不可禁), while “the migration of villains” (jianmin zhi du 奸民之渡) “must definitely be forbidden” (bi buke bujin 必不可不禁). ${ }^{67}$ Wanderers, who had no family or property attachment, were believed to be prone to cause trouble and were thus excluded from receiving a permit. Consequently, a 1730 (Yongzheng 8) regulation stipulated that people who did not have property or family in Taiwan, or who had property or family but committed certain criminal acts, were to be repatriated from Taiwan. ${ }^{68}$ A 1751 (Qianlong 16) regulation reiterated the same law in slightly different terms. ${ }^{69}$

Scholars have argued that the government "tightened" or "relaxed" the migration control at different times. ${ }^{70}$ However a close look at the regulations reveals that the changes were superficial. Chart 8 shows that the regulations were largely consistent, and the government repeatedly warned against and tried to curb illegal crossing. The only changes over the years were on whether or not to allow migrants to bring families to Taiwan. ${ }^{71}$ The central

(TWWX 66), at 325. Ming Qing dang'an, above n 40, vol 9, at 56-58, attributes (in estimation) two regulations of the Ministry of Wars against illegal crossing without a permit and against family migration to Taiwan to 1684 (Kangxi 23).

${ }^{65}$ See Zhou, ibid, at 325. Also see a report by the Fujian-Zhejiang Governor-General Jueluo Manbao in 1724 (Yongzheng 2), in Ming Qing dang'an, ibid, vol 10, at 108-111: “臺灣無此田畧供耕種，第治安隱憂”. ${ }^{66}$ Ibid.

${ }^{67}$ Taiwan Prefect Shen Qiyuan's essay in about 1729 (Yongzheng 7), in ibid, vol 13, at 220-223.

${ }^{68}$ Taiwan shili, above n 64, at 168.

${ }^{69}$ At 171.

${ }^{70}$ For the policy shifts between "tightening" and "relaxing" over time, see Chuang Chin-Teh "Qingchu yanjin yanhai renmin toudu lai Tai shimo" [An Account of the prohibition of migration from coastal China to Taiwan in the early Qing period] (1964) 15(3)\&(4) Taiwan Wen Hsien 1-20 (Part 1), 40-62 (Part 2); Ji Yunfei "Tongzhi jiaxu qian Qing zhengfu Taiwan yimin zhengce zhi tanxi" [An analysis of the Qing government's policies concerning migration to Taiwan before 1874] [1998] 5 Xueshujie 64-68.

${ }^{71}$ Evidence cited in ibid to prove relaxation or tightening up of migration was also about the family reunion policy. 
principles of controlling what kind of people could migrate and of monitoring the movements of people through the permit system never wavered. This was designed to ensure the social order on the island and the security of the Qing rule, which were always the prime considerations.

\section{Chart 8 Imperial Regulations Concerning Migration to Taiwan*}

\begin{tabular}{|c|c|}
\hline Year & Law \\
\hline $1712($ KX 51) & $\begin{array}{l}\text { Permit needed to go to Taiwan. Officials not to issue permit in an irresponsible } \\
\text { manner. "Good subjects" (liangmin) could apply to reside in Taiwan. }\end{array}$ \\
\hline $1729($ YZ 7) & Policing illegal crossing. Officials to be punished if negligent. \\
\hline $1730(\mathrm{YZ} 8)$ & $\begin{array}{l}\text { Those settlers in Taiwan who did not have a family be expelled from Taiwan, those } \\
\text { who had family and property but engaged in unruly activities be punished } \\
\text { according to law. }\end{array}$ \\
\hline 1734(YZ 12) & Boat owners/operators to be punished if illegally taking passengers. \\
\hline 1736 (QL 1) & Policing illegal crossing. Officials to be punished if negligent. \\
\hline 1737 (QL 2) & $\begin{array}{l}\text { Tightening up the permit system, and details of boats and the crews to Taiwan to } \\
\text { be recorded. Taiwan local officials to record details of local residence. }\end{array}$ \\
\hline $1740(\mathrm{QL} 5)$ & $\begin{array}{l}\text { Where boats took passengers illegally, boat owners/operators and illegal } \\
\text { passengers punished. }\end{array}$ \\
\hline 1745 (QL 10) & $\begin{array}{l}\text { Migrants could only apply for wives and children to go to Taiwan, and no other } \\
\text { relatives. }\end{array}$ \\
\hline 1747 (QL 12) & $\begin{array}{l}\text { Procedures prescribed for bringing families to Taiwan, and officials to be punished } \\
\text { if issuing permits irresponsibly. }\end{array}$ \\
\hline $1761(\mathrm{QL} \mathrm{26})$ & $\begin{array}{l}\text { Permit needed to go to Taiwan, and the only port of departure was Xiamen. Policing } \\
\text { illegal crossing. Officials to be punished if negligent and to be rewarded if diligent. } \\
\text { Family reunion migration closed. }\end{array}$ \\
\hline 1770 (QL 35) & $\begin{array}{l}\text { Policing illegal crossing. Officials to be punished if negligent and to be rewarded } \\
\text { if diligent; boat owners and passengers to be punished for breaches. }\end{array}$ \\
\hline 1772 (QL 37) & $\begin{array}{l}\text { To punish a range of people if involved in the illegal crossing business, including } \\
\text { organisers, boat crews and passengers. }\end{array}$ \\
\hline 1784 (QL 49) & $\begin{array}{l}\text { Taiwan settlers were allowed to go back to reside in their place of origin in } \\
\text { mainland China without a permit. They could only depart from Lu'ermen 鹿耳門 } \\
\text { port. Other ports must be strictly policed against boats arriving and departing. }\end{array}$ \\
\hline 1788 (QL53) & $\begin{array}{l}\text { To open another port in Taiwan so as to reduce illegal crossing (prompted by the } \\
\text { Lin Shuangwen uprising). }\end{array}$ \\
\hline 1789 (QL54) & $\begin{array}{l}\text { Officials not to extort from applicants going to Taiwan so as to reduce illegal } \\
\text { crossing. }\end{array}$ \\
\hline 1800 (JQ 5) & $\begin{array}{l}\text { Policing illegal crossing. Officials to be punished if negligent and to be rewarded } \\
\text { if diligent. Settlers who were in Taiwan could apply for residency if they had family } \\
\text { and property, otherwise would be expelled back to their place of origin. }\end{array}$ \\
\hline 1801 (JQ 6) & Policing illegal crossing. Officials to be punished if negligent. \\
\hline
\end{tabular}

*Source: Qing huidian Taiwan shili, at 30-32, 38, 150-151 and 168-172. These were all government regulations. Other recommendations that might have been approved by the emperors but not made a regulation are not included.

$(\mathrm{KX}=$ Kangxi, $\mathrm{YZ}=$ Yongzheng $, \mathrm{QL}=\mathrm{Qianlong}, \mathrm{JQ}=\mathrm{Jiaqing})$ 


\section{Segregation}

Policies of segregation included building boundaries to separate settlements from aboriginal territories, as well as forbidding interaction between settlers and the nonacculturated aborigines, in particular marriage.

The policy to segregate settlement areas from the aboriginal territories was introduced in 1722 (Kangxi 61). This was the direct response to the 1721 Zhu Yigui uprising, an event that aggravated security concerns. Fifty-four stelae were erected at crucial points to mark boundaries between settlement areas and aboriginal territories (see Chart 10A). The areas west of the boundaries - the settlement areas - were called "within the boundaries" (jienei 界内), and the areas east of the boundaries - the aboriginal territories - were called "beyond the boundaries" (jiewai 界外). Han settlers were confined to the western plains and were forbidden to cross the boundaries. ${ }^{72}$

As shown in Chart 9, the subsequent Yongzheng and Qianlong governments made regulations to reiterate the ban against entering the mountain territories. Because of settler encroachment, the Qianlong government four times, in 1750, 1760, 1784 and 1790 (Qianlong 15, 25, 49 and 55 respectively), investigated the border areas, and clarified and rebuilt boundaries. ${ }^{73}$ Each time the boundary lines were marked on maps in colours, being red, blue, purple and green in the respective years. Settlement expansion pushed the boundaries towards the foothills (see Chart 10B for the boundaries in the mid-Qianlong reigns), but the government was determined that boundaries must remain to separate the settlers from the non-acculturated aborigines.

\footnotetext{
${ }^{72}$ See a regulation of the Ministry of Wars in about 1722 (Kangxi 61), in Ming Qing dang'an, above n 40, vol 9, at 376-77.

${ }^{73}$ See Lin Yu-ju and Wei Dong "Lin Shuangwen shijian qian de Taiwan bianqu tuxiang: yi Qianlong 49 nian Taiwan fanjie zixiantu wei zhongxin" [Frontier areas in Taiwan before the Lin Shuangwen uprising: an investigation centering on the 1784 purple-line aboriginal boundaries] (2012) 19:3 Taiwanshi yanjiu 47, at 73.
} 
Chart 9 Imperial Regulations Concerning Aboriginal Territories*

\begin{tabular}{|l|l|}
\hline \multicolumn{1}{|c|}{ Year } & \multicolumn{1}{c|}{ Law } \\
\hline 1722 (KX 61) & Local officials to be punished if settlers crossed the aboriginal boundaries. \\
\hline 1730 (YZ 8) & $\begin{array}{l}\text { Those Han settlers who entered the aboriginal territories and squatted aboriginal } \\
\text { land or were engaged in other illegal activities to be punished. }\end{array}$ \\
\hline 1737 (QL 2) & $\begin{array}{l}\text { Settlers who entered the aboriginal territories to be punished. Officials to be } \\
\text { rewarded or punished according to their achievements in apprehending settlers } \\
\text { who entered the aboriginal territories. }\end{array}$ \\
\hline 1746 (QL 11) & Those who entered the aboriginal territories to reclaim land to be punished. \\
\hline 1754 (QL 19) & $\begin{array}{l}\text { Officials to be punished if non-acculturated aborigines killed settlers (caused by } \\
\text { settlers entering the aboriginal territories). }\end{array}$ \\
\hline 1794 (QL 59) & As the 1737 regulation. \\
\hline
\end{tabular}

*Source: Qing huidian Taiwan shili, at 24, 27, 29, 167 and 168. These were all government regulations.

Other recommendations that might have been approved by the emperors but not made a regulation are not included.

Chart 10 Aboriginal Boundaries during the Kangxi and Qianlong Reigns (source: Academia Sinica, Taiwan History and Culture in Time and Space)
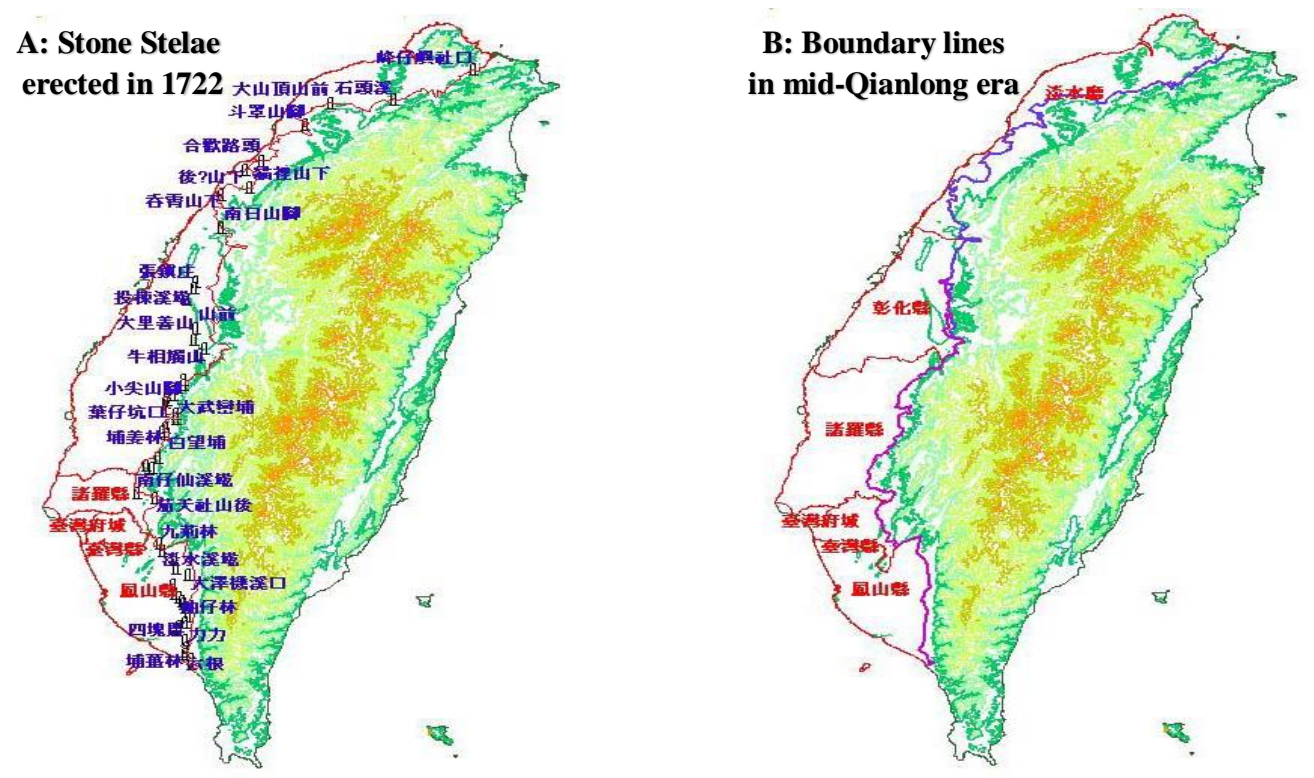

Another type of segregation policy was forbidding inter-marriage between Han Chinese and the non-acculturated aborigines. This was forbidden by a regulation made in 1737 (Qianlong 2). ${ }^{74}$ The ban was likely to have been in place during the Kangxi reign, since an

\footnotetext{
${ }^{74}$ Taiwan shili, above n 64, at 27.
} 
Inspecting Censor for Taiwan recorded in the late Kangxi era that if Han people secretly married (daoqu 盗娶) aboriginal women, the consequence was divorce and punishment according to law. ${ }^{75}$

In summary, throughout the Kangxi, Yongzheng and Qianlong reigns, policies to control settlement remained largely consistent. The family reunion aspect of the migration policy was tightened or relaxed at times, and the boundaries were redrawn a few times. However, essentially the "quarantine" policies remained in place and were many times reiterated. Even the Yongzheng government, which was said to be "pro-colonisation", was vigorous in regulating illegal crossing and monitoring the integrity of the aboriginal boundaries, which were the essence of "quarantine".

The "quarantine" policy had the effect of slowing down settlement. Migration control served to reduce the influx of settlers from mainland China, and aboriginal boundaries isolated the aboriginal territories and made them unavailable for settlement or land reclamation. The law against inter-marriage to some extent also protected aboriginal land, since marrying aboriginal women was one of the means by which Han settlers obtained their land. Migration control and segregation both had the actual effect, if properly carried out, of restricting colonisation of Taiwan, reducing pressure for land, and thus protecting aborigines from being deprived of their land. They were often seen as the government's anti-colonisation and anti-development stance, and the relaxation on their implementation or the wavering of policies were often seen as a change of direction towards expansion.

Despite the practical effects of restricting colonisation, the migration and segregation policies were only a means to achieve the government's ultimate objective. The purpose of migration control was to preclude trouble-makers from settling a land that at one time had harboured pirates and rebels. The rationale of segregation was to minimise contacts between Han settlers and non-acculturated aborigines, and to prevent conflicts or alliance between these two groups. ${ }^{76}$ Therefore although the policies might serve to reduce

\footnotetext{
${ }^{75}$ Huang, above n 39, at 170.

76 This was so in Taiwan as well as other frontiers. See Robert HG Lee The Manchurian Frontier in Ch'ing History (Harvard University Press, Cambridge (Mass), 1970), at 21.
} 
settlement and land reclamation, colonisation was not part of the consideration in the policy design, rather security of the regime and social stability in Taiwan were the prime concerns.

This fundamental policy trend of "quarantine" continued until 1875, when the government formally abolished restrictions on migration. However, in responding to new situations that arose in the late 1700s and early 1800s, the government began to implement or attempt measures to expand administration and settlement. Hence government policies entered a transitional stage at this time.

\section{Policies in Transition}

In the early $19^{\text {th }}$ century, the Qing Court and officials, although they continued with previous policies of migration control and segregation, subtly changed their attitudes towards aboriginal territories.

The overarching policies of "quarantine" were maintained. The Jiaqing government in 1800 (Jiaqing 5) made regulations to hold officials responsible for illegal crossing and to require deportation of wanderers who had no family or property in Taiwan (see Chart 8). Another regulation prohibiting Han settlers from entering aboriginal territories and interacting with aborigines was made in 1807 (Jiaqing 12). ${ }^{77}$ The Daoguang government approved "twenty guidelines on Taiwan affairs", which included provisions on controlling illegal migration from the mainland and policing the aboriginal boundaries. ${ }^{78}$ Therefore there was continuity in policy-making. However a new trend that pushed for changes also emerged at this time.

From the early 1800 s, local officials repeatedly pressed for the colonisation of aboriginal territories. The two salient cases were Gamalan and inner Shuishalian. Although the only visible outcome was the incorporation of Gamalan into the realm, the repeated recommendations concerning Gamalan and the debates over inner Shuishalian both

\footnotetext{
77 Taiwan shili, above n 64, at 167-168.

78 臺湾善后章程二十条. See Qing Xuanzong shilu xuanji [Selected veritable records of the Daoguang Emperor] (TWWX 188), at 161-165
} 
evidenced a turn towards a policy of expansion. However, the desire for expansion was provoked by growing threats to Taiwan and the empire.

\section{A Gamalan}

Being separated from the plains in the west and the Danshui Sub-prefecture at the northwest by mountains, Gamalan was situated "beyond the boundaries". Traditionally 36 aboriginal villages were located in the area. The Gamalan aborigines started paying tax to the Qing government during the Kangxi reign, which meant that technically they were submitted aborigines, but they remained non-acculturated. ${ }^{79}$ The Gamalan aborigines continued to live without disturbance until the beginning of the Jiaqing reign, when Chinese settlement started and subsequently government administration was established.

Chinese settlers pioneered the settlement of Gamalan, but not without the local officials' support. In 1787 (Qianlong 52), a Han settler, Wu Sha, attempted to reclaim land in Gamalan, but was defeated by the aborigines. ${ }^{80}$ The next year, the then Danshui Subprefect persuaded the Taiwan Prefect, Yang Tingli, to support $\mathrm{Wu}$ Sha. Yang recommended that the Fujian Governor should subjugate the aborigines and open up Gamalan for settlement, which the Governor refused to do for fear of the aborigines' retribution. ${ }^{81}$ In 1797 (Jiaqing 2), a new Danshui Sub-prefect issued a permit and provided financial support for $\mathrm{Wu}$ to recruit people to reclaim the land. ${ }^{82}$ As Gamalan was out of bounds, this step was in fact against the regulations. Subsequent efforts by Wu's successors to register reclaimed land on the government register were declined. ${ }^{83}$ Clearly local officials favoured land reclamation, but they were bound by government regulations

\footnotetext{
${ }^{79}$ Different records had the timing in 1695 (Kangxi 34) or the late Kangxi era. See Chen Shujun Gamalan tingzhi [Gazetteer of Gamalan Sub-prefecture, 1852] (TWWX 160), at 3; Ke Gamalan zhilüe, above ch $1 \mathrm{n}$ 134 , at 9 .

${ }^{80} \mathrm{Ke}$, ibid, at 9-10.

81 Yao Ying Dongcha jilüe [Records of my appointment to the east, 1829] (TWWX 7), at 72.

${ }^{82} \mathrm{Ke}$, above n 79, at 174; Chen, above n 79, at 330.

${ }^{83}$ Ibid. Wen Chen-hua Taiwan yuanzhumin shi zhengce pian: Qingzhi shiqi [History of Taiwan aborigines: the policy chapter: the Qing period] (Taiwan Historical, Nantou, 2007), at 74, also indicates that Wu did not obtain the rights of yezhu (業主 registered property owner), which meant the land was not registered.
} 
against land settlement in the aboriginal territories and consequently chose to acquiesce in the reclamation.

In the meantime, local officials continued to press for the extension of the administration to Gamalan. They probably would not have succeeded had it not been for pirate activities in Taiwanese waters. In 1806 (Jiaqing 11), the then Fuzhou Garrison General, Saichong'a, reported to the Emperor that a notorious pirate Cai Qian was prowling the fertile land of Gamalan. The Emperor ordered officials to investigate the situation. ${ }^{84}$ The next year the Taiwan Prefect Yang, in an audience with the Emperor, recommended opening up Gamalan, reasoning that it was "not advisable to abandon it and leave a cause for trouble in the frontier". ${ }^{85}$ Later when another pirate band attempted to occupy Gamalan, Yang again recommended to the Fuzhou General Saichong'a to establish administration and start surveying the land in Gamalan. For some reason Saichong'a refused, but he soon changed his mind and sent a memorial to the Emperor in early 1808 (Jiaqing 13), recommending incorporation of Gamalan. ${ }^{86}$

Saichong'a's memorial was discussed by the central government officials. One official reasoned that "if [Gamalan was] incorporated into the realm, it could not only end pirates' prowling, but also [allow the government to] benefit ( $l i$ 利 “profit") from the land in the overseas frontier". ${ }^{87}$ This was the first known incident that acquiring a territory was associated with "profit" in a positive sense in the history of Qing administration of Taiwan. This was not surprising, since after the prosperity and peace of the earlier reigns, the Jiaqing government was under great demographic pressure - the population of China had more than doubled in the previous century to over 300 million, and pressure on land had greatly increased. ${ }^{88}$ Southwest and central China were flooded with land hungry migrants. At the same time, the population in Taiwan had also increased dramatically. By 1811 (Jiaqing 16),

\footnotetext{
84 Yao, above n 81, at 73 .

85 Ibid, “不宜棄置貽邊患”。

${ }^{86}$ At 74. For Saichong'a's memorial, see Ming Qing dang'an, above n 40, vol 46, at 489-494.

87 “若收入版圖，不特絕洋盗窺伺之端，且可獲海疆之利”. Yao, ibid, at 74.

${ }^{88}$ See Jones and Kuhn, above n 15, at 108-110.
} 
the settler population had reached 1,944,737, one million up from 943,414 in 1790 (Qianlong 55). ${ }^{89}$

The pressure on land accounted for the local officials' growing desire to expand, but it was the pirate threat that pushed the Court to finally incorporate Gamalan into the realm. In early 1809 (Jiaqing 14), the Emperor ordered the then Fujian-Zhejiang Governor-General Alinbao to start working on incorporation of Gamalan. The Emperor reasoned that the land was fertile, which made it the object of coveting by robbers and rebels, and for this reason became the source of troubles in Taiwan..$^{90}$ The Emperor shied away from economic gains, and justified the expansion on security grounds. In 1810 (Jiaqing 15) an imperial decree was issued to formally incorporate Gamalan, and a Gamalan Sub-prefect was subsequently appointed. ${ }^{91}$

Thus after over a century's quarantine, for the first time the government expanded administration over the central mountain ranges (see Chart 11). Even before the pirate threats became an issue, local officials in Taiwan supported or acquiesced in settlers' reclamation, and attempted to persuade their superiors to incorporate Gamalan. This displayed a new interest in expansion and colonisation, which likely had grown out of the need to ease population pressure in the western plains and to increase tax revenue. However, security threats remained the main driving force for the government action.

\footnotetext{
${ }^{89}$ Sheng Ch'ing-I, Wang Shi-lang and Gao Shu-fan Taiwan shi [History of Taiwan] (Taiwansheng wenxian weiyuanhui, Taizhong, 1977), at 297; Chuang "Qingdai Taiwan tudi kaifa yu zuqun chongtu", above "Introduction" $\mathrm{n}$ 4, at 5.

${ }^{90}$ See Yao, above n 81, at 74.

${ }^{91}$ See Qing Renzong shilu xuanji [Selected veritable records of the Jiaqing Emperor] (TWWX 187), at 165166; Taiwan shili, above n 64, at 9.
} 
Chart 11 Administrative Area during the Jiaqing Reign (Source: Academia Sinica, Taiwan History and Culture in Time and Space)

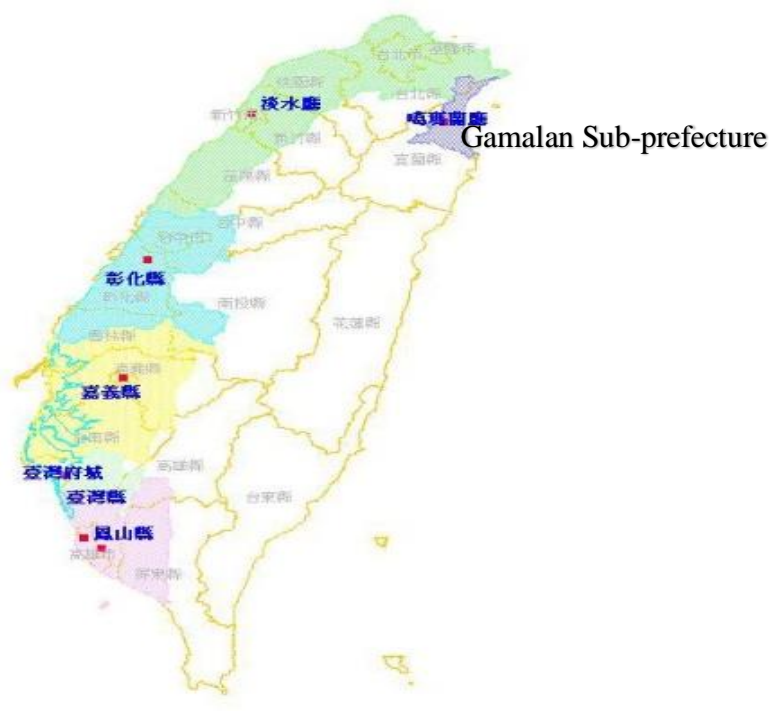

\section{B The Debate on Inner Shuishalian}

Unlike the case of Gamalan, debates on inner Shuishalian resulted in the continuing closeoff of the area. Nevertheless the fact that the matter was repeatedly discussed signifies a changing attitude within the government.

Shuishalian refers to the upstream areas of two rivers in central Taiwan - the Wu River and the Zhuoshui River. The historical records sometimes refer to different localities in the area. ${ }^{92}$ The locality that caused much discussion during the Daoguang reign was the "inner mountain area of Shuishalian” (Shuishalian neishan 水沙連内山). ${ }^{93}$ Traditionally 24 aboriginal villages were located in this area, and six of them occupied a piece of flat and fertile land. It was this piece of land that was the subject of an incident during the Jiaqing reign, and which was the cause of much debate in 1823, 1841 and 1846 (Daoguang 3, 21 and 26).

\footnotetext{
${ }^{92}$ See Chen Zhe-san “'Shuishalian' jiqi xiangguan wenti zhi yanjiu” [A research on Shuishalian and related issues] (1998) 49(2) Taiwan Wen Hsien 35-57. ${ }^{93}$ At 50 .
} 


\section{An incident during the Jiaqing reign}

Like Gamalan, inner Shuishalian was located beyond the aboriginal boundaries, and the land was fertile. The aborigines had submitted themselves to the Qing government, some villages submitting as early as 1693 (Kangxi 32 ) ${ }^{94}$ As the area was located among the mountains, the people remained non-acculturated aborigines.

Settlers coveted this fertile land and had tried to reclaim it even though it was clearly a forbidden area. In 1814 (Jiaqing 19), some settlers had obtained land reclamation permits through fabricating the aborigines' request to lease the land to settlers. The settlers subsequently reclaimed over 1,200 jia of land in inner Shuishalian, causing serious armed conflicts with the aborigines. ${ }^{95}$ As a result, in 1816 (Jiaqing 21) the government sent troops to destroy the settler strongholds, expelled the settlers, and erected stelae with inscribed decrees forbidding reclamation of the land by Chinese settlers. ${ }^{96}$

The contrast between the Jiaqing government's approaches towards Gamalan and inner Shuishalian demonstrates the weight of security on government decision-making, since Gamalan was faced with pirate threats while inner Shuishalian was not. Furthermore, the settler leaders in inner Shuishalian ruthlessly killed many aborigines and caused a great deal of bloodshed. While the settlement of Gamalan also met aboriginal resistance, the settlers' leader, Wu Sha, was more prudent and was said to have helped the aborigines to defeat outside intrusions and to have saved the aborigines' lives when an epidemic struck. ${ }^{97}$ Thus the lack of external threat and the presence of settler-aborigine conflicts determined the different outcome for Shuishalian under the Jiaqing government.

\section{Debates in the Daoguang years}

The suggestion to open up inner Shuishalian was made several times during the Daoguang reign, the first time being in 1823 (Daoguang 3) by the Aboriginal Affairs Sub-prefect for the Northern Circuit, Deng Chuan'an. After a visit to inner Shuishalian, Deng found that

\footnotetext{
${ }^{94}$ At 40.

${ }^{95}$ See Yao, above n 81, at 34-35.

${ }^{96}$ Ibid.

${ }^{97} \mathrm{Ibid}$, at 70 ; Ke, above $\mathrm{n} 79$, at 89-90.
} 
the land could be developed into thousands of qing of good farms, ${ }^{98}$ but the aborigines, including some migrant plains aborigines, were not good at farming. ${ }^{99}$ Deng lamented that the land was situated beyond the aboriginal boundaries, and recommended to his superiors to open up Shuishalian. ${ }^{100}$ The Fujian Governor was interested, but the then Gamalan Subprefect Yao Ying discouraged them, citing administrative costs issues and the unwillingness of the aborigines. ${ }^{101}$

The same issue was brought up again nearly two decades later, but this time the consideration extended to all land that could be and had yet to be reclaimed in Taiwan. In 1841 (Daoguang 21), the Daoguang Emperor, after receiving a recommendation from a central government official, decreed that the Fujian-Zhejiang Governor-General investigate unreclaimed land in Taiwan with the objective of increasing revenue to help with maritime defence. ${ }^{102}$ The immediate cause for concern was the Opium War between China and Britain which commenced in 1840, but the wider context was the decline of the empire. During the Daoguang reign, the Qing Court was faced with a silver reserve drain, eroding army strength and weakening government control. ${ }^{103}$ The government began to look for new sources of revenue, and colonising the aboriginal territories was one such source.

The plan was again shelved after the revenue and cost were weighed, and still the central consideration was security. The former Gamalan Sub-prefect, Yao Ying, was by then the Taiwan Circuit Intendant, the highest ranking official based in Taiwan. In his letter to the Governor-General, Yao discussed unreclaimed land in the whole of Taiwan, including inner Shuishalian and the eastern coast. ${ }^{104}$ Yao reasoned that Shuishalian was not by the coast, and therefore there was little risk of foreign possession of it. Yao then weighed up the risk of foreign possession of eastern coastal areas and the costs to open up those areas

\footnotetext{
98 The equivalence of tens of thousands of jia.

99 See Deng Chuan'an Lice huichao [Measuring the sea with a calabash, 1830] (TWWX 9), at 6.

${ }^{100}$ Ibid; Yao, above n 81, at 36.

101 Yao, ibid, at 36-38.

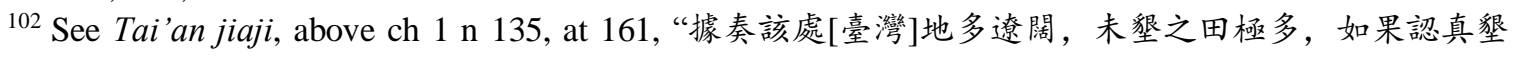
種，即以每歲所入鴬福建海防，可潛消英夷覬覦”.

103 Jones and Kuhn, above n 15, at 146.

104 See Yao's letter in Tai'an jiaji, above n 102, at 163-167.
} 
for settlement. To open up the areas would involve either sending troops to subjugate the aborigines or spending money and material to appease them, and both options were costly. Yao pointed out that in the administration of Taiwan costs had always been larger than revenue, and that it was false to hope that allowing land reclamation could raise revenue for maritime defence. Since there was no imminent threat, and given the costs that would be involved, the matter was again put to rest. ${ }^{105}$

Population and revenue pressure continued to mount, and within a few years local officials had renewed their interest to colonise inner Shuishalian. In 1846 (Daoguang 26), a new Fujian-Zhejiang Governor-General, Liu Yunke, argued that opening up inner Shuishalian would eliminate five evils and bring five benefits, the evils being causes to social instability, and the benefits being increased revenue and increased social stability. ${ }^{106} \mathrm{Liu}$ was careful to centre his argument on social order, but central government officials were conservative and were not convinced. The Emperor ordered Liu to travel to Shuishalian and investigate the situation in person, which Liu did, before furnishing a detailed report about the aborigines and their land. ${ }^{107}$

The central government in the end refused to open up the area. As in the 1841 discussion, it was thought that the administrative cost would be significantly higher than the revenue, and also because foreign threats were not imminent. There was also a fear that the benefits that might come with land reclamation would become a cause of other trouble, especially rebellions and foreign coveting. ${ }^{108}$

That was the final decision on inner Shuishalian, although local officials still tried to find opportunities to open up the land. In 1848 (Daoguang 28), a new Taiwan Circuit Intendant, upon arriving at the post, recommended establishing aboriginal colonies in inner

\footnotetext{
105 At 161-163.

106 See Liu's memorial in Ding Yuejian Zhi Tai bigaolu [A collection of must-read documents on governing Taiwan, 1868] (TWWX 17), at 207-212.

107 At 212-228.

108 See the Grand Councilor Muzhang'a's memorial in ibid, at 227-228.
} 
Shuishalian. This was in fact a way to circumvent the central government decision and to have inner Shuishalian land reclaimed. ${ }^{109}$ No response to this suggestion was recorded. ${ }^{110}$

Thus, the Qing government and officials gave serious consideration to colonising the aboriginal territories, and gave up the plan after considering the low risks of foreign intervention and the cost of administration. The major consideration was once again security. Revenue and costs were part of the calculation, but they were used as arguments against colonisation, the rationale being that there was no need to spend more money if security was not an issue.

\section{A New Trend, and an Old Consideration}

As shown in the cases of Gamalan and inner Shuishalian, a new interest in expansion emerged in the early 1800s, when successive government officials advocated opening up the aboriginal territories. During the first century of Qing administration of Taiwan, Lan Dingyuan of the early Yongzheng years was the only "pro-colonist" who advocated expanding government control and land settlement. Since the early 1800s, there appeared to be an undercurrent of support for expansion. A long term Taiwan official, Ding Yuejian, who was posted to Taiwan under the successive Daoguang, Xianfeng and Tongzhi governments, compiled a book to advise on "administration of Taiwan". ${ }^{111}$ The collection started with Lan Dingyuan's writings, proceeded with documents and writings on Gamalan and Shuishalian, and was followed by discussions on opening up aboriginal territories and defence against foreigners. The book illustrates the strategic thinking of some Qing officials of the early to mid- $19^{\text {th }}$ century, and their desire for expansion.

Not only was Gamalan incorporated and inner Shuishalian considered for colonisation, officials also envisaged or argued for extending government control to the whole island. Yao Ying, the official who several times had argued against opening up Shuishalian, expected that not only inner Shuishalian, but also the whole eastern territories, would be

\footnotetext{
109 See the Intendant's recommendation in ibid, at 272-281.

${ }^{110}$ Scholars have suggested that it was not adopted. For example, see Wen, above n 83, at 81.

${ }^{111}$ Ding, above n 106.
} 
incorporated into the empire within the next hundred years. ${ }^{112}$ Yao preferred a gradual strategy, which was to acquiesce in Han settlement and for the government to reap the benefits when the time was right. Others, however, were more radical than Yao. In 1867 (Tongzhi 6), an official in Fujian argued that following the incorporation of Gamalan the government should extend control over inner Shuishalian, and eventually over the remaining portion of the aboriginal territories. ${ }^{113}$ This official directly recommended that "the back of the mountains [the aboriginal territories] should be opened, and the aborigines should be subjugated". ${ }^{114}$ The Danshui Sub-prefecture Gazetteer, compiled in 1871 under the leadership of the Sub-prefect, recommended opening up the mountains and subjugating the aborigines as the best option for the empire. ${ }^{115}$ Therefore after the incorporation of Gamalan, colonisation of the remaining aboriginal territories was a topic of continuing discussion, and strategic thinking about "opening the mountains and subjugating the aborigines" had already emerged before 1874 .

The new attitude in favour of expansion was a reaction to the general security issues, which the post-1800 government faced. The government tried to exercise control over the aboriginal territories as a means to resist outside threats, and tried to raise revenue to fund defence. The fact that Gamalan was incorporated, while inner Shuishalian or other aboriginal territories were not, was because Gamalan faced direct pirate threats, while the government did not perceive any security threats to the other areas to be imminent. The arguments for expansion were not adopted until 1874 when the threat against Taiwan materialised.

\section{IV $\quad$ Promoting Settlement}

Although 1875 has been seen as the turning point of Qing policies in Taiwan, in fact there were two stages of colonisation efforts, both of which were in response to foreign threats.

\footnotetext{
112 Yao, above n 81, at 36.

${ }^{113}$ See the letter to the Fujian-Zhejiang Governor-General in Luo Dachun Taiwan haifang bing kaishan riji, [A journal of maritime defence and mountain opening in Taiwan] (TWWX 308), at 65-68. The author of this letter did not identify himself, but at 88 it is indicated that it was an official in the Fujian Province.

114 Ibid, at 66, “後山...宜開，生番...宜撫”.

115 “上策開闢内山招徠番族”. Chen Peigui Danshui tingzhi [Gazetteer of Danshui Sub-Prefecture, 1871]
} (TWWX 172), at 19. 
The first one commenced in 1874 after the Japanese invasion of southern Taiwan, and the second in 1885 after French occupation of Jilong in northern Taiwan. Both efforts diminished within a few years after the foreign threats subsided, reflecting the usual Qing pattern of expansion only for security reasons.

\section{A Events in 1874-1875}

In 1874 (Tongzhi 13), Japan invaded the aboriginal territory in southern Taiwan. This is known as the Mudanshe Incident (Mudanshe shijian 牡丹社事件). For over six months Japanese soldiers occupied southern Taiwan, which, Japan argued, was not part of the Qing Empire. The background to this incident and the arguments of both parties will be further discussed in Chapter 6. Here it needs only be pointed out that the incident resulted in the Qing Court paying an indemnity to Japan in return for the Japanese army's withdrawal from Taiwan. The Qing court realised that Taiwan as a whole could be lost if any part of it was not brought under government control, and losing Taiwan meant exposing the coastal provinces to foreign threats.

The Imperial Commissioner to Taiwan (Qinchai Taiwan shiwu dachen 欽差㗌灣事務大

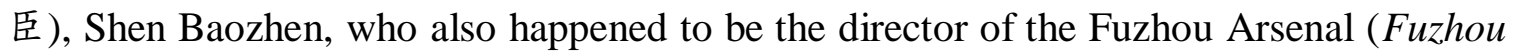
zaochuanchang 福州造船廠) and an important figure in the late Qing self-strengthening movement, argued for colonisation of the aboriginal territories. Shen argued that "the reason that Taiwan is being coveted by [Japan] is that the land is too empty; the land is empty because the people are few", ${ }^{116}$ and recommended to "open the mountains and subjugate the aborigines" and populate the aboriginal territories with Chinese settlers. ${ }^{117}$ Following Shen's recommendation, administration in Taiwan was expanded, and campaigns to colonise the aboriginal territories were launched.

A new prefecture, Taipei Prefecture, was created. The sub-prefectures of Danshui and Gamalan were raised to the status of counties, and renamed Xinzhu and Yilan respectively.

\footnotetext{
116 “臺地所以鴬彼族䀓䀓者, 病于土曠; 土曠之病, 由於人稀”, quoted in Luo, above n 113, at 38 .

117 See Shen's memorial in Fujian Taiwan zouzhe [Memorials on Taiwan] (TWWX 29), at 11-13 ("Taiwan zouzhe").
} 
Two new counties, Hengchun at the far south and Danshui at the far north, were created. Further, two sub-prefectures were established in inner Shuishalian and eastern Taiwan. Formal administration was thus extended to inner Shuishalian, east of the mountain ranges, and the far south of the island (see Charts 12A and 13).

The "opening the mountains and subjugating the aborigines" campaigns started in 1874 and continued into the early Guangxu reign. "Opening the mountains" included building roads across the mountains to make the region accessible, and "subjugating the aborigines" meant bringing the mountain aborigines into formal submission to the Qing regime. In 1874 (Tongzhi 13) and 1875 (Guangxu 1), troops were sent to build roads across the mountains, connecting the area "at the back of the mountains" (the east) to that "in the front of the mountains" (the west). There were three major road building projects: in the north, the middle and the south of the island respectively. Five roads cut through the mountain ranges, totalling nearly $900 \mathrm{li}^{118}$ The government tried to subjugate aborigines wherever the road building troops advanced to. In many cases aborigines resisted government troops, and armed conflicts occurred frequently. ${ }^{119}$

Another important aspect of "opening" was the opening of Taiwan for Chinese settlement. In the first year of the Guangxu reign (1875), the Emperor proclaimed that the two-centuryold ban on crossing the Taiwan Strait was abolished, with the objective of encouraging settlement: ${ }^{120}$

After the whole island of Taiwan, Fujian, entered the realm, because the aboriginal villages at the back of the mountains had different customs, [the government] has forbidden the mainland people from migrating to Taiwan and entering the aboriginal territories (fanjing 番境), so as to prevent trouble. Now Shen Baozhen and other

\footnotetext{
118 Inō Taiwan wenhua zhi, above "Introduction" n 32, vol 3, at 198.

${ }^{119}$ For example, see records in Liu Mingchuan fu Tai qianhou dang'an [Historic documents before and after Liu Mingchuan's governorship in Taiwan] (TWWX 276) (“Fu Tai dang'an").

${ }^{120}$ Qing Dezong shilu xuanji [Selected veritable records of the Guangxu Emperor] (TWWX 193), at 3: “福 建臺灣全島自隸版圖以來, 因後山各番社習俗異宜, 曾禁內地民人渡薹及私入番境, 以杜滋生事端. 現 經沈葆楨等將後山地面設法開闢, 曠土亟須招墾; 一切規制, 自應因時變通. 所有從前不准內地民人渡 薹各例禁, 著悉與開除; 其販買鐵竹兩項, 著一律弛禁, 以廣招徠”. This was made a regulation, see Taiwan shili, above n 64, at 44 .
} 
officials have opened up the territories at the back of the mountains, and the vacant land needs to be reclaimed urgently. All rules should be changed as situations change. All previous regulations that forbid people from migrating to Taiwan are now abolished. The control on sale of iron and bamboos are loosened. ${ }^{121}$ This is to encourage migration and settlement.

As typical of the Qing's law making, the decree was less than precise, since it did not explicitly abolish regulations that forbade Han settlers from entering the aboriginal territories. This was only implied in the decree, given that the ultimate goal was to have people settle in the aboriginal territories and reclaim the land.

The government established agencies in coastal cities in the mainland and in Hong Kong to recruit settlers to Taiwan. ${ }^{122}$ The government arranged for transportation of the recruits to Taiwan; provided them with seeds, draft oxen and other tools, plus a living allowance for one year; and gave a three-year tax grace period for land reclaimed. ${ }^{123}$ Before much progress was made, Shen was appointed to be the Governor-General of other provinces. Another official who was committed to promoting settlement in the aboriginal territories, the Fujian Governor Ding Richang, also left the post in 1878 (Guangxu 4). After that the opening and subjugating campaigns virtually ceased.

The colonisation efforts in the late Tongzhi and early Guangxu years were provoked by foreign threats, with the clear purpose of avoiding any further incidents and to strengthen the Qing government's ability to defend its territory. Shen Baozhen made it clear that "our strategies to the areas at the back of the mountains are for preventing troubles, not for gaining profits". ${ }^{124} \mathrm{He}$ went on to state that: ${ }^{125}$

everyone knows that today we open the mountains to subjugate the aborigines, but not everyone knows that subjugating the aborigines is for maritime defence; everyone knows

\footnotetext{
121 The previous control on sale of iron and bamboos was to prevent the people from keeping weapons.

${ }^{122}$ See records in Linshi Taiwan Jiuguan Diaochahui Taiwan sifa fulu cankaoshu [Private law of Taiwan reference book] (Taipei, 1910) vol 1A, at 7 ("Sifa cankao").

123 At 9-12.

${ }^{124}$ Luo, above n 113, at 60, “臣等經營後山，鴬防患計，非鴬興利計”.

125 At 59, “人第知今日開山之䍃簬番, 固不知今日撫番實以防海也; 人第知預籌防海之關係臺灣安 危，而不知預箁防海之關係南北洋全局也”。
} 
that preparing for maritime defence is crucial to the safety of Taiwan, but not everyone knows that it is crucial to the whole situation of the south and north seas.

Security being the paramount consideration, it is not surprising that when the foreign threats appeared to have passed, government efforts relaxed. It took another crisis to revive government efforts to promote settlement in Taiwan.

\section{B The 1885 Campaigns}

The same scenario repeated after another foreign threat occurred a decade later.

In 1883 the Sino-French war broke out, ${ }^{126}$ and in 1884 the French army occupied Jilong in northern Taiwan and threatened Taipei. ${ }^{127}$ Subsequent to the cease-fire agreement and the withdrawal of the French army from Taiwan in 1885, Liu Mingchuan, the Taiwan Defence Commissioner (Taiwan fangwu dachen 臺灣防務大臣) and Fujian Governor, renewed the efforts to "expand territory and encourage reclamation" (kuojiang zhaoken 扩疆招圣) in the aboriginal territories. The administrative system was further expanded and strengthened.

Administering Taiwan became the sole focus of the Fujian Governor in 1885 (Guangxu 11), while the administration of the Fujian Province was entrusted to the Governor-General. Taiwan finally became a separate province in 1887 (Guangxu 13). The administrative units were reorganised and local administration was further expanded in 1888 (Guangxu 14). Another prefecture and three additional counties were established. The eastern part of Taiwan was governed through a newly created Taidong Department (Taidong zhou 薹束 州 “eastern Taiwan department”), which worked directly under the provincial government. Further adjustments were made in the next two years. By that time, Taiwan had changed from a prefecture with three counties at the beginning of the annexation to a province with three prefectures, 11 counties, one department and three sub-prefectures (as shown in Chart 12B and Chart 13).

\footnotetext{
126 The Sino-French war was over Vietnam, which was under Qing suzerainty at that time.

127 See Lian, above n 24, at 405-414 about the Sino-French war Taiwan zone.
} 
Chart 12 Administrative Units in Taiwan in 1875 and 1894 (Source: Academia Sinica, Taiwan History and Culture in Time and Space)

\section{A: 1875}

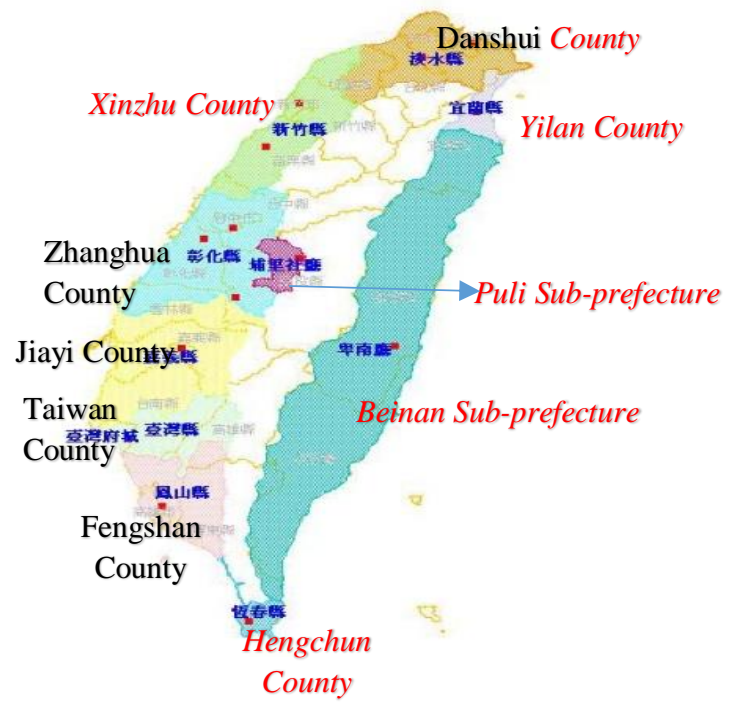

B: 1894

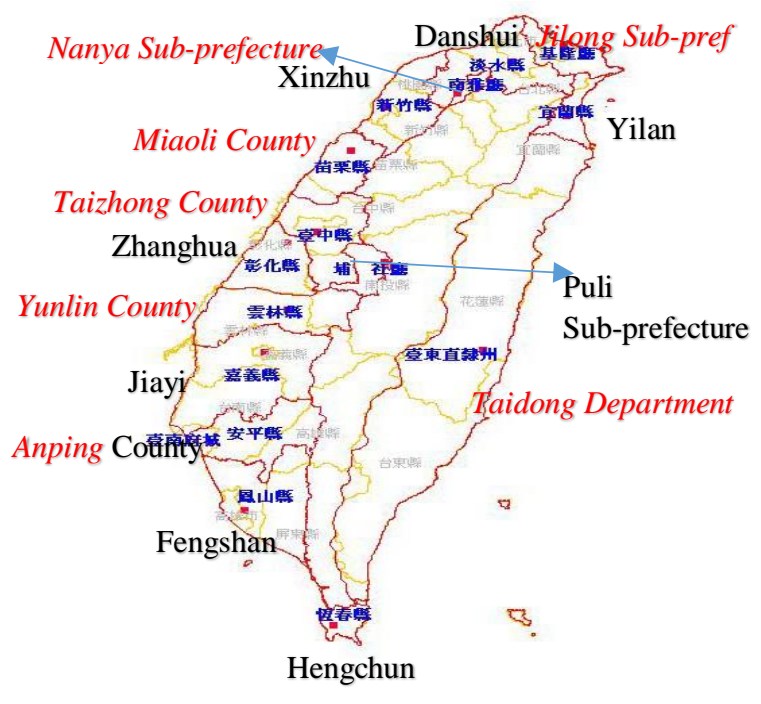

*New establishments or new names are indicated in italics and red. 
Chart 13 Changes of Local Administration in Taiwan

\begin{tabular}{|c|c|c|c|c|}
\hline & Prefecture & County & Sub-prefecture & $\begin{array}{l}\text { sub-prefect } \\
\text { (position only) }\end{array}$ \\
\hline $1684(\mathrm{KX} 23)$ & Taiwan & $\begin{array}{l}\text { Taiwan } \\
\text { Fengshan } \\
\text { Zhuluo } \\
\end{array}$ & & \\
\hline 1723 (YZ1) & & +Zhanghua & tDanshui & \\
\hline 1812 (JQ17) & & & „Gamalan & \\
\hline \multirow[t]{2}{*}{1875 (GX1) } & Taiwan & $\begin{array}{l}\text { Taiwan } \\
\text { Fengshan } \\
\text { Jiayi (Zhuluo) } \\
\text { Zhanghua } \\
+ \text { Hengchun }\end{array}$ & & \multirow{2}{*}{$\begin{array}{l}\text { Aborigine affairs } \\
\text { (established in } \\
1766 \text { but moved } \\
\text { to aboriginal } \\
\text { territories of): } \\
\text { - Beinan } \\
\text { - Puli }\end{array}$} \\
\hline & +Taipei & $\begin{array}{l}\text { Xinzhu } \\
\text { Yilan } \\
\text { +Danshui }\end{array}$ & & \\
\hline \multirow[t]{4}{*}{$\begin{array}{l}1887 \text { (GX13) } \\
\text { Taiwan } \\
\text { Province }\end{array}$} & $\begin{array}{l}\text { Tainan } \\
\text { (formerly Taiwan) }\end{array}$ & $\begin{array}{l}\text { Anping } \\
\text { (formerly Taiwan) } \\
\text { Fengshan } \\
\text { Jiayi } \\
\text { Hengchun } \\
\end{array}$ & & \\
\hline & +Taiwan & $\begin{array}{l}\text { Zhanghua } \\
\text { +Taiwan } \\
\text { +Yunlin } \\
\text { +Miaoli }\end{array}$ & Puli (1889) & \\
\hline & Taipei & $\begin{array}{l}\text { Danshui } \\
\text { Xinzhu } \\
\text { Yilan }\end{array}$ & $\begin{array}{l}\text { Jilong (1889) } \\
\text { Nanya }(1895)\end{array}$ & \\
\hline & $\begin{array}{l}\text { +Taidong } \\
\text { (Department) }\end{array}$ & & & \\
\hline
\end{tabular}

To facilitate the pacification and reclamation work, a Taiwan Pacification and Reclamation Head Office (Taiwan fuken zongju 臺灣撫墾總局) was established, heading eight pacification and reclamation bureaus and 18 branches at various crucial spots around Taiwan. ${ }^{128}$ By 1887 (Guangxu 3), nearly 500 aboriginal villages with about 90,000 aborigines had formally submitted, which would enable reclamation of tens of thousands

128 At $457-458$. 
of jia of land. ${ }^{129}$ Within a few years this number had increased to over 800 villages with 148,479 aborigines. ${ }^{130}$

While the number of villages and aborigines that submitted themselves to the Qing authority looks impressive, criticisms followed and problems surfaced. The government usually used materials to induce the aborigines into submission, and paid village heads monthly allowances once the aboriginal communities had submitted. The cost was high, but the government was not always able to exercise effective control over the aborigines. Furthermore, after years of promotion and facilitation, the progress of land reclamation was slow. By 1891, only 2,255 jia of land was reclaimed and registered in eastern Taiwan, and the situation was not much better in southern Taiwan. ${ }^{131}$ Many reasons were given for this failure at times, such as that most labourers were attracted to Southeast Asia and few went to Taiwan, that the few settlers were intimidated or attacked by aborigines, that the areas to be settled were too remote, or that the climate was harsh and few settlers survived. ${ }^{132}$

The reality was that, as the security threats seemed to have subsided, the calculation of revenue and costs re-surfaced. Liu was criticised for the high cost of and little gain from the opening and subjugating activities. Liu resigned in 1891 (Guangxu 17), and colonisation efforts ceased. Although administrative units expanded, the government could not maintain effective control over the non-acculturated aborigines, and much of the reclaimed land returned to "waste". It was likely that even without the cession of Taiwan to Japan in 1895, the Qing government would not have made much progress in colonising the aboriginal territories.

\footnotetext{
129 See details in Liu Mingchuan Liu Zhuangsugong zouyi [Memorials of Liu Mingchuan] (TWWX 27), at 220.

${ }^{130}$ Inō, above n 118, vol 3, at 311. Inō thinks the actual number was about one tenth of that.

${ }^{131} \mathrm{Hu}$ Taidongzhou caifangce, above ch $1 \mathrm{n} 138$, at 42.

${ }^{132}$ See Linshi Taiwan Jiuguan Diaochahui Taiwan sifa [Private law of Taiwan] vol 1 (Chinese translation, Taiwansheng wenxian weiyuanhui, Taizhong, 1990, original first published in 1910), at 47; Inō, above n 118, vol 3, at 2014; Sheng Ch'ing-I "Qingdai Taiwan Tong-Guang zhiji kaishan fufan shishi biannian” [Chronicles of the "opening the mountains and subjugating the aborigines" campaigns during the Tongzhi and Guangxu years] (1979) 30(3) Taiwan Wen Hsien 1, at 11; Lian, above n 24, at 447.
} 
The post-1874 development again shows that security was the single most important factor that drove the government to expand. Revenue and control costs were cited only to dissuade expansion when security threats were not imminent or serious enough.

\section{Qing Tradition and the Formation of Policy on Taiwan}

Over the two centuries of Qing administration in Taiwan, government policies concerning settlement and colonisation of Taiwan experienced a controlling settlement stage, a transitional stage and finally a stage of promoting settlement. As demonstrated in this chapter, the underlying policy rationale was consistently security. When the central government was strong, it tightly restricted colonisation. When the government grew weak and faced security threats, it tried to defend the realm through expansion. When threats diminished, the desire to expand disappeared and the focus became that of avoiding costs. The methods the government adopted for Taiwan had parallels in other Qing frontiers, and the policy rationale had its root in the Chinese tradition of governance.

"Quarantine" was the usual approach used by the Qing government in the frontiers to preserve social order and security. This was what happened in Taiwan as in other frontiers, including Manchuria, Mongolia, Xinjiang and southwest China. In other words, Taiwan was not unique, but typical.

There were parallels to the migration control in other Qing frontiers. Manchuria was closed to settlement, mainly because of its status as the Qing ruler's native place. ${ }^{133}$ Mongolia was also closed off from settlement until the late 1800s. Despite the government's encouragement of land settlement in Xinjiang and the southwest frontier, regulations imposed restrictions on people's movement to these areas similar to those for Taiwan. ${ }^{134}$ Therefore migration control tried to stop movement of people and prevent Chinese

\footnotetext{
${ }^{133}$ Lee, above $\mathrm{n} 76$, at 20.

${ }^{134}$ See Yang Jun Qingdai Xinjiang diqu falü zhidu jiqi bianqian yanjiu [A research on the legal system and its evolution in Qing Xinjiang] (Minzu, Beijing, 2012), at 46; C Patterson Giersch Asian Borderlands: The Transformation of Qing China's Yunnan Frontier (Harvard University Press, Cambridge (Mass) and London, 2006), at 132 and 211. Also see, in general, Zhang, above n 9, ch 7.
} 
settlement, as well as to screen migrants to prevent perceived trouble-makers from going to the frontier areas.

The aboriginal boundary in Taiwan was partly an inheritance from the Zheng regime, which had built boundaries to separate the settlement areas from the aboriginal territories. However it was the Qing's own tradition of segregating different ethnic groups which sustained the policy for nearly 200 years. In 1623 Nurhaci implemented policies to segregate the Han from the Manchus within his realm after serious conflicts between the two peoples had occurred. ${ }^{135}$ This tradition had continued to be used to ensure peaceful relations between different ethnic groups. ${ }^{136}$ In Xinjiang, the government segregated different ethnic groups, containing them in Manchu quarters, Han quarters and Hui (Muslim) quarters respectively. ${ }^{137}$ Although the Qing encouraged land settlement in Xinjiang after the conquest in 1759, the Hui areas were not opened for settlement. ${ }^{138}$ In the southwest frontier of Yunnan, there was a division of "inner" and "outer" territories, the outer territories including those that were occupied by "barbarian subjects", who were similar to the non-acculturated aborigines in Taiwan. ${ }^{139}$ In the Miao area in the Hunan and Guizhou provinces (southwest China), Han settlers were banned from entering into Miao land. ${ }^{140}$ The Qing also built willow palisades to exclude Manchuria from Han settlement and encroachment.

There were also similar policies against intermarriage between Han Chinese and minority ethnic groups such as the Manchus, the Hui in Xinjiang, and the Miao in the southwest. ${ }^{141}$ In fact regulations forbidding intermarriage and entrance to Taiwan's mountain aboriginal territories specifically cited the Miao regulations as precedents. ${ }^{142}$ This again shows the consistency of Qing policies in frontier regions.

\footnotetext{
${ }^{135} \mathrm{Li}$, above n 4 , at 48 .

${ }^{136}$ Elliott, above n 16, at 99.

137 Yang, above n 134, at 45.

138 At 310.

${ }^{139}$ Giersch, above n 134, at 61.

140 Donald S Sutton "Violence and Ethnicity on a Qing Colonial Frontier: Customary and Statutory Law in the Eighteenth-Century Miao Pale" (2003) 37 Modern Asian Studies 41, at 62; Zhang, above n 9, at 518.

${ }^{141}$ Yang, above n 134, at 46; Sutton, ibid, at 62; Rowe, above n 17, at 508.

${ }^{142}$ See Taiwan shili, above n 64, at 27.
} 
It was also a Qing pattern to populate frontiers with settlers, with the purpose to strengthen border defence at times when external threats overshadowed the potential risk of internal conflicts. This occurred at different times, but mostly during the late Qing period when the empire was under increasing foreign threats from various directions. In the early Qing period, the government had waged wars against the Zunghars in central Asia for decades, and finally pacified the area in 1759. ${ }^{143}$ To consolidate government control, the Qing Court encouraged and organised settlements in the area. ${ }^{144}$ In the mid- $19^{\text {th }}$ century, the Qing government faced serious threats from foreign states such as Russia, France, and subsequently Japan. In particular north-eastern Manchuria was lost to Russia in 1860. The northern frontier of the Qing Empire, from Manchuria to Xinjiang, was opened to Russian influence. ${ }^{145}$ In response the government opened Mongolia and Manchuria for Chinese settlement in the late 1800s, the purpose being to "populate the frontier with settlers to strengthen frontier defence" (yimin shibian 移民實邊). ${ }^{146}$

Putting the policies into their historical context, it is clear that colonisation corresponded with the perception of external threats. When there was no external threat, the Court focused on preventing internal conflicts, and preserved the status quo of the conquered land through "quarantine" policies. When the dynasty started to decline and faced external threats, the minds of officials and literati were motivated to search for opportunities to strengthen and defend the empire, including ways of expansion and occupation. When crisis struck, the government quickly acted to guard frontier areas against foreign invasion. The typical way of guarding frontiers was to fill them with people, that is, settlers from the heartland. Thus the weaker the empire grew, the more aggressive it was in promoting settlement.

Qing policies in Taiwan were consistent with those in other frontiers, although the exact timing was not always the same. The variations in timing can be explained by the different

\footnotetext{
${ }^{143}$ See Di Cosmo, above $\mathrm{n}$ 5, in general.

${ }^{144}$ Tang Qiyu Zhongguo de kenzhi [Land reclamation and colonisation in China] (2ed, Yongxiang, Shanghai, $1952)$, at 54.

${ }^{145}$ See Joseph Fletcher "Sino-Russian Relations, 1800-1862" in Fairbank (ed), above n 15, 318, at 332-348.

${ }^{146}$ Tang, above n 144, at 16-17 and 47; Joseph Fletcher "The Heyday of the Ch'ing Order in Mongolia, Sinkiang and Tibet" in Fairbank(ed), ibid, 351, at 357.
} 
local situations. No matter whether quarantine or colonisation, the purpose was always to maintain social stability and security. It has been said that "there was nothing that the [Qing] wanted from [inner Asia] but peace". ${ }^{147}$ The same could be said of Taiwan, or any other frontiers of the Qing.

The focus on security and social order was largely because of the Chinese tradition on governance. Two principles of Confucian legal thought were monarchism (junzhu zhuyi $尹$ 主主義) and people-centredness ( $m$ in benwei 民本位). ${ }^{148}$ The Confucian tradition saw the monarch as a boat and the people as water, and the most important task of statecraft was to keep the boat afloat, that is, to preserve the monarchy. ${ }^{149}$ Therefore the principle of monarchism in essence put the monarch in the centre of the constitutional framework, and the principle of people-centredness was a way to preserve the rule by the imperial house. The governing of the empire revolved around ensuring the ruling authority of the monarch over the masses. The Manchu house as a conquest elite and minority ruler was particularly mindful of the need to maintain the security of their rule. Therefore security was placed in a paramount position in the Qing Court's decision-making regarding the periphery, and hence its security-paramount approach towards the colonisation of Taiwan.

Furthermore, in Chinese tradition, the purpose of managing peripheries was to "defend against enemies", since "to expand the territory and reclaim the land to extract [resources] was not what a sage king would do", as was aptly summarised by a Taiwan official. ${ }^{150}$ Therefore expansion was a means to defend the borders, and the emperors and officials mostly shied away from extracting resources or revenue from the land. Indeed the Qing government did not intend to exploit the land, nor to deprive the Taiwanese aborigines of their land. Instead it recognised and attempted to protect their land rights, at least where security considerations allowed. These questions are explored further in the next chapter.

\footnotetext{
${ }^{147}$ Joseph Fletcher "Ch'ing Inner Asia c 1800” in Fairbank (ed), ibid, 35, at 106.

148 Yang et al (eds), above n 26, at 24.

149 “君者, 舟也; 庶人者, 水也。水能載舟，亦能覆舟”. Xunzi [The works of Xunzi] ch 9 “Wangzhi” [On the regulations of a king] (Chinese Text Project www.ctext.org). For translations of selected works of Xunzi, see Homer H Dubs (trans) The Works of Hsüntze (Confucius Publishing, Taipei, 1972).

150 “古之善籌邊者, 卻敵而已。開疆闢土, 利其有者, 非聖王所欲䍃”. Ke, above n 79, at 168.
} 


\section{Chapter 3}

\section{Recognition and Protection of Aboriginal Land Holdings}

Studies of Qing aboriginal land policies in Taiwan have largely focused on the period up to about 1800. Scholars argue that the Qing government was protective of the aboriginal land rights but that the protection was ineffective, either because of poor policy or inadequate measures of protection, ${ }^{1}$ or poor implementation by corrupt officials. ${ }^{2}$ These interpretations, however, have been made on the basis of restricted case studies, rather than by analysing Qing aboriginal land policies as a whole. While the standard interpretation appears to be true in some cases, it is an oversimplification of the situation as a whole. Looked at over the full length of the Qing rule in Taiwan, it is clear that the recognition and protection of aboriginal land rights went through a number of changes. The protection policies were typically dependent on Qing recognition of aboriginal land rights, and both recognition and protection of aboriginal land rights operated within a framework of Chinese legal tradition.

This chapter analyses Qing recognition and protection of aboriginal land rights and the effects of the Qing legal tradition on the recognition and protection. Parts I introduces the Chinese land tenure as it operated during the Qing period. Part II traces the gradual emergence of the concept of aboriginal land and the commencement of protection during the Kangxi reign. Part III examines the short-lived removal of the ban against reclaiming aboriginal land during the Yongzheng reign. Part IV discusses the vigorous protection of land rights during the early to mid-Qianlong reign and the establishment of aboriginal colonies in the late Qianlong period. Part V analyses the new approaches during the Jiaqing and Daoguang reigns to aboriginal land in newly or to-be acquired territories, namely

\footnotetext{
${ }^{1}$ For example, Shih Tien-fu “Qingdai Taiwan 'fanli bu'an gengzuo' de yuanyou” [The reasons behind the aborigines being "unskilful at farming"] (1990) 69 Bulletin of the Institute of Ethnology Academia Sinica 67, at 77-87; Wu Qi-hao "You Dadushe zai tan Qingdai Taiwan zhi shufan diquan" [A discussion of the acculturated aborigines' land rights through a case study on the Dadu village] (2003) 20 Taiwan shiliao yanjiu 34, at 62.

${ }^{2}$ For example, Chen Chiu-kun "Shijiu shiji chuqi tuzhu diquan wailiu wenti - yi Anlishe de tudi jingying weili" [The aborigines' land loss in the early $19^{\text {th }}$ century - a case study on the land management of the Anli village] in Chen Chiu-kun and Hsu Hsueh-chi (eds) Taiwan lishi shang de tudi wenti [Land issues in historical Taiwan] (Academia Sinica, Taipei, 1992) 29, at 30; Chen Qingdai Taiwan tuzhu diquan, above "Introduction" n 43, at 222-223.
} 
Gamalan and inner Shuishalian. Part VI discusses post-1875 land policies. Part VII concludes that the Qing government generally recognised aborigines' property rights in land, and analyses the effects of Qing legal tradition on its recognition and protection of aboriginal rights.

\section{Qing Land Tenure}

\section{A "All Land Belongs to the King"}

\section{General development}

Chinese tradition assumed that "all land under Heaven belongs to the King", meaning that the "King" owned all land once a territory entered the realm. ${ }^{3}$ It is important, however, to clarify what exactly constituted the King's ownership, especially the "ownership" over wasteland.

During the Western Zhou period (1059-771BC), land tenure was feudal. Similar to the feudal land tenure in English history, the King granted fiefs to the lords, who owed allegiance to the King. The lords granted smaller fiefs to lesser lords, and at the bottom of the ladder were commoners who worked on the land. ${ }^{4}$ Under a system called "jingtian" (井 田, 井-shaped fields), the lords divided land into 9-plot pieces as shown in the character 井 (jing), and allocated one piece to every eight households. Each household occupied and cultivated one plot, and all eight households worked on the plot in the middle which yielded produce for the lord. The households usually rotated occupation of the plots, and did not have rights to dispose of the land. ${ }^{5}$ This feudal arrangement was the origin of the saying "all land under Heaven belongs to the King". There was no private land ownership under that arrangement.

\footnotetext{
${ }^{3}$ Shijing.xiaoya.beishan [Book of Songs], “普天之下莫非王土” (Chinese Text Project, www.ctext.org).

${ }^{4}$ Wang Wenjia Zhongguo tudi zhidushi [History of Chinese land tenure] (Zhongzheng, Taipei, 1956), at 2628.

${ }^{5}$ There exist ancient records about the system. Although there are some doubts as to whether it was a record of practice or a suggestion of design, scholars argue for existence of the tenure. See Zhao Gang and Chen Zhongyi Zhongguo tudi zhidushi [History of Chinese land tenure] (Lianjing, Taipei, 1982), at 1-3; Chen Guyuan Zhongguo fazhishi [Legal history of China] (Zhongguo shudian, Beijing, 1988, facsimile copy of Shangwu yinshuguan, 1934), at 326-327.
} 
The feudal system of land tenure broke down in the Warring States period (476-221BC), during which time the Qin state abolished the jingtian system. The unification of the warring states in China by the Qin Dynasty (221-207BC) saw the formal establishment of new administrative and land systems. ${ }^{6}$ Hereditary feudal lords were replaced by appointed administrative officials, and the "King" that "owned" all land was no longer necessarily the person of the King or the Emperor, or the government which the Emperor presided over. It is a concept akin to the "Crown" in the British constitution, which could refer to the sovereign or the government in different contexts. Common people were given private proprietary interests over land. The government allocated land to households (shoutian 授 田) who then had their land registered and paid land tax. Land became inheritable and alienable, although the system fluctuated and evolved over millennia.

Scholars are generally of the view that private land ownership emerged in China during the Qin Dynasty, ${ }^{7}$ but some scholars argue that there was no private land ownership in imperial China, because of the concept that the "King" owned all land. ${ }^{8}$ Given the alienability and inheritability of land rights, which were the characteristics of private ownership, arguably private land ownership existed in imperial China, in a form analogous to holding land of the Crown in the English land tenure. As such the substance of the "King's ownership" changed from proprietary rights to an underlying title that represented public law power.

\section{Wasteland}

Chinese imperial government asserted control over uncultivated land, and even the scholars who recognised private land ownership in imperial China were of the view that the government "owned" wasteland. ${ }^{9}$ However the nature of the government's "ownership" is worth examining. Uncultivated land was called "wasteland" (huangdi 荒地). There were usually two types of wasteland, virgin land (yuanhuang 原荒 “originally waste”) and cultivated land that became waste (paohuang 抛荒 “left to waste”), usually because of war.

\footnotetext{
${ }^{6}$ See Zhao and Chen, ibid, ch 1, for the development of land system since the Qin Dynasty.

${ }^{7}$ For example, ibid, at 19; Chen, above n 5, at 327.

${ }^{8}$ For example, Taiwan sifa, above ch 2 n 132, vol 1, at 52; Wang Tay-sheng Taiwan falüshi gailun [Introduction to the history of laws of Taiwan] (4ed, Yuanzhao, Taipei, 2012), at 77 and 79.

${ }^{9}$ For example, Zhao and Chen, above n 5, at 41.
} 
Yuanhuang land remained in the government's hands and was subject to grant. Paohuang land could revert to government control and became available for grant if the original owners or cultivators did not claim it back. Virgin land and paohuang land that reverted to government control were usually referred to as "land without an owner" (wuzhudi 無主地, bona vacantia), although occasionally it was also called "government's land" (guandi 官 地). ${ }^{10}$ Anyone could reclaim wasteland into agricultural land and apply for a grant, usually free of charge and sometimes even with government subsidies as an incentive for land reclamation. ${ }^{11}$ Therefore the government's "ownership" was not proprietary interests, instead it was an administrative power to make or not to make grants, and to decide to whom to grant the land.

The government could be a land owner in the sense of a private land owner, when it appropriated land to itself, an equivalent to the European law concept of dominium. A typical type of land owned by the government was official estates (guanzhuang 官莊), in which the land was managed by the government and the rental income set aside for various types of official use, depending on the purposes and circumstances of establishing the estates. This was in contrast to the government's rights over "wasteland", which were limited to the power to make grants.

Therefore in imperial China the sovereign or the government did not "own" the land, not even wasteland, in the sense of possessing propriety rights, except in cases where the government owned cultivated land in the same manner as other private landowners did. The "King" exercised his "ownership" in the area of public administration. The Qing Dynasty inherited this system, but it retained certain wasteland as guanhuang (官荒 wasteland owned by the government), which was wasteland that was not to be granted for reclamation. ${ }^{12}$ In this case the government in fact granted the land to itself.

\footnotetext{
${ }^{10}$ At 52.

${ }^{11}$ At 194.

${ }^{12}$ At 59.
} 


\section{B Land Grants}

During the Qing Dynasty, land grants were made after land reclamation was completed. After the Qing Court was established in Beijing, although the government made regulations to encourage land reclamation, no procedure was set out for land reclamation. Land reclaimers were only required to report to the local government after the reclamation was completed. The local government then surveyed the land and recorded the relevant information on the land register.

Land registers were kept for taxation and other administrative purposes. ${ }^{13} \mathrm{~A}$ "fish scale register" (yulin ce 鱼鳞册), devised during the Southern Song Dynasty (1127-1279AD), recorded the location of each piece of land, the total area, boundaries, the registered proprietor's name, the tenant's name and the proprietors of adjacent lands. ${ }^{14}$ Another register, the “yellow register" (huang ce 黄册), recorded each household's land holding. Both registers functioned as the basis for tax collection. The "fish scale register" focused on land information, and the "yellow register" focused on household information. Because these registers, which the Qing Dynasty inherited from earlier dynasties, were not always updated when transactions or subdivision occurred, the Qing government created a transaction register (tuishou ce 推收册) to record changes of land holdings. ${ }^{15}$ The purpose of these registers was to provide the government with correct information for taxation, but upon registration, a grant was deemed to have been made. In contrast, wasteland was not surveyed or registered. ${ }^{16}$

The Qing government was concerned only with registering reclaimed land, and did not regulate the reclamation process at the central government level for many decades. Because disputes arose over whether land being reclaimed had prior owners or reclaimers, in 1661 (Shunzhi 18) an Inspecting Censor for Henan Province recommended that reclaimers apply for land reclamation licences in advance, listing relevant details including the reclaimer's

\footnotetext{
${ }^{13}$ For detailed accounts of the registers mentioned in this paragraph, see ibid, at 81-86.

${ }^{14}$ At 81. Pictures of land as drawn on the register often resembled the shape of fish scales, hence the name.

15 At 83. The "yellow register" was adjusted and renamed "red register" during the Kangxi reign.

16 At 81 .
} 
name and the land in question. ${ }^{17}$ This was approved but probably it was applied only in Henan, as regulations made by the Yongzheng government still required reclaimers to “reclaim and report on their own account” (ziken zibao 自墾自報) and “report as soon as reclaimed” (suiken suibao 隨墾隨報). ${ }^{18}$ A 1734 (Yongzheng 12) regulation required local officials to publish information about land that was reported by reclaimers and give a fivemonth notice period, so that other interested parties could object to registration by the current reclaimer. ${ }^{19}$ It was not until 1737 (Qianlong 2) that the government required prior application before reclamation (ying xian chengbao 應先呈報). ${ }^{20}$ The freedom to reclaim land without prior government approval was further evidence that the government did not assert property rights over wasteland, and the eventual improvement in regulating the reclamation process was to avoid disputes among the people.

Different from the general practice in the mainland China, a reclamation permit system was applied in Taiwan, which was likely to have been inherited from the Zheng period. Zheng regulations required prior government approval for land reclamation, officials to apply to Zheng himself, and ordinary people to the Prefecture government. ${ }^{21}$ The reason of this requirement is unclear, but it appears that the local Taiwan government continued this practice after Qing annexation. ${ }^{22}$ Land reclamation permits recorded the permit holder's details and the location and boundaries of the land, but as in the empire-wide practice, the land was not surveyed until after the permit holder "reported for survey and taxation" (baozhang shengke 報丈升科) when the reclamation was completed.

It was in the process of issuing land permits that aboriginal land issues emerged and were eventually dealt with.

\footnotetext{
${ }^{17}$ See Wenxian tongkao, above "Introduction" $\mathrm{n} 54$, vol 1, at 27.

${ }^{18} \mathrm{Vol} \mathrm{3}$, at 1 and 20.

${ }^{19}$ Huidian shili, above "Introduction" n 53, vol 166 (no pagination).

${ }^{20}$ Ibid. Also see Wenxian tongkao, above n 17, vol 4, at 13.

${ }^{21}$ Yang Congzheng shilu, above ch $1 \mathrm{n}$ 111, at 190.

${ }^{22}$ Qingdai Taiwan dazu diaochashu [Collection of large rent documents in Qing Taiwan] (TWWX 152), collects land reclamation permits issued as early as 1685, the year after the annexation ("Dazu diaocha"). Land permits will be examined in ch 4.
} 


\section{Aboriginal Land: an Emerging Concept}

\section{A Ignorance about Aboriginal Land Rights}

The concept of aboriginal land did not emerge in the years immediately after annexation. Because of the traditional concept that all land within the realm belonged to the "Crown", after annexation Qing officials acted on the assumption that once the aborigines submitted, the government gained an ultimate title over the land. There was no concept that any ethnic groups had ownership over wasteland.

In the early years of annexation local officials encouraged land reclamation in Taiwan. The first Taiwan Prefect, Jiang Yuying, encouraged land reclamation and agricultural activities. $^{23}$ The first Zhuluo County magistrate, Ji Qiguang (Kangxi 23-24), called for land reclamation by settlers, saying that "as one could see [from] the south to the north, grass lands are wild and vacant [huangwu 荒無]. If [we] have people to reclaim them, they will become fertile lands". ${ }^{24} \mathrm{Ji}$ recommended recruiting peasants from the mainland, and providing settlers with land and draft oxen. Driven by his belief, Ji "worked hard to solicit [settlers], so that population on the register could be increased, and new farmland could be opened in the wilderness". 25

A few years later, another Zhuluo County magistrate, Zhang Fa (Kangxi 29-33), "saw that the county was newly established, and [there was] much vacant land, [so he] encouraged land reclamation...". ${ }^{26}$ The encouragement of land reclamation was because much land had been abandoned or had reverted to waste in Taiwan due to the change of dynasty, and also because of the general policy of the empire to encourage land reclamation. ${ }^{27}$ Local officials bore personal responsibility for implementing such policies, as their competency was judged according to their achievements in terms of local land reclamation and their

\footnotetext{
${ }^{23}$ Song "Qingdai Taiwan fuken cuoshi zhi chengxiao jiqi yingxiang”, above "Introduction" n 34, at 145.

24 Ji Qiguang “Tiaochen Taiwan shiyiwen” [A discussion on Taiwan affairs] in Ming Qing dang'an, above “Introduction” n 55, vol 9, at 228, “南北草地一望荒無，得人開墾，可成沃壤”.

25 At 107, “多方招徠，因而冊有續增之丁口，野有新辟之田園”.

${ }^{26}$ Fan Chongxiu Taiwan fuzhi, above ch 1 n 29, at 137.

27 The Shunzhi and Kangxi governments both provided extended grace tax periods to encourage land reclamation. See the decrees in Huidian shili, above n 19, vol 166 (no pagination). Also see Wenxian tongkao, above n 17, vol 1, at 16 and vol 2, at 13.
} 
diligence in tax collection. ${ }^{28}$ Given China's agrarian tradition, among officials there was also an inherent desire to turn wild land into production.

At first local officials issued land reclamation permits without paying any attention to aboriginal land rights, possibly because no occasion arose to challenge the traditional concept that wasteland was subject to government grant. The Taiwan magistrate, Ji, stated in an essay about Taiwan affairs that "once [the territory] is annexed... every inch of field is the Emperor's land, every person is the Emperor's subject". ${ }^{29}$ Although the context was collecting land tax and poll tax from Han settlers, Ji's statement had a general application given the call for land reclamation. Since all land titles must flow from the Emperor, some Qing officials assumed that even land occupied by aborigines was on the basis of a grant from the Emperor. An early Taiwan Prefect, Zhou Yuanwen (Kangxi 46-52), expressed the view that "because the aborigines did not know agriculture, [the Emperor] granted land to the aborigines for deer hunting". ${ }^{30}$ There was of course never any such grant, but Zhou's statement assumed all land titles must flow from the Emperor's grant, since the Emperor "owned" all land within the realm. This was therefore a kind of fictional grant, as in English law.

Another reason for the lack of understanding of aboriginal land rights was that, in the first few decades of Qing rule, land reclamation was mainly on formerly cultivated land that had reverted to wasteland when the Zhengs surrendered. Consequently the aborigines did not demonstrate strong claims over such land as they did with their deer grounds.

As discussed in Chapter 1, during the Kangxi era land reclamation advanced slowly and it took nearly 40 years for the area of registered land to increase to the level of the Zheng period. The government and local officials were not aware of the issue of aboriginal land rights because, in the absence of settler-aborigine conflicts and aboriginal protest against

\footnotetext{
${ }^{28}$ See decrees issued in 1644 (Shunzhi 1), 1671 (Kangxi 10), 1724 (Yongzheng 2) in Huidian shili, ibid, vol 166 (no pagination); Wenxian tongkao, ibid, vol 2, at 12 and vol 3, at 8.

${ }^{29}$ Ji Qiguang "Zaichen Taiwan shiyiwen" [A further discussion on Taiwan affairs] in Chen Wenda Taiwan xianzhi [Gazetteer of Taiwan County, 1720] (TWWX 103), at 232, “既入版圖...則尺地皆王土，一民皆王 人”.

${ }^{30}$ Zhou Chongxiu Taiwan fuzhi, above ch $2 \mathrm{n}$ 64, at 316, “因土番不諳耕種，原撥定地土與土番捕鹿”.
} 
land reclamation, the traditional belief that all land "belonged" to the "Crown" was not challenged. As land reclamation became more widespread, aboriginal land rights started to become an important issue.

\section{B Understanding Aboriginal Land Rights}

As land reclamation advanced, officials became aware of the effects of settlement on the wellbeing of the aborigines. Officials were sympathetic towards the aborigines and attempted to protect them, seeing them as the weaker people having to withstand the invasion of the Han migrants. A Zhuluo County magistrate, Zhou Zhongxuan (Kangxi 5355), complained that the aborigines were being oppressed and exploited by Han settlers and officials, and that aboriginal hunting grounds had become settlers' farmland, leaving aborigines with only a small proportion of their land on which to maintain themselves. ${ }^{31}$ Other officials issued decrees forbidding exploitation of the aborigines, and made efforts to relieve their hardship. ${ }^{32}$

In about 1704 (Kangxi 43), Taiwan Circuit Intendant Wang Minzheng (Kangxi 42-48) issued a decree concerning aboriginal land rights: ${ }^{33}$

If the Han people and acculturated aborigines make agreements freely between themselves (renyi qiyue 任意契約), and the aborigines give up their wasteland (huangpu 荒埔) for [settlers to] reclaim, they [the settlers] should first apply to the government [for a reclamation permit]. Local officials shall investigate all details of the transaction and the relationship between the settlers and the aborigines, and decide whether to approve the application. Those [settlers] who are granted a permit must fulfil the contractual obligations (qiyue tianjian 契約條件) with the aborigines, and report the land for taxation according to law...

\footnotetext{
${ }^{31}$ Fan, above n 26, at 478-479.

${ }^{32}$ For example, Zhuluo County magistrate, Ji Qiguang, and Xiamen-Taiwan Circuit Intendant, Gao Gongqian (Kangxi 32-34), both issued such decrees. See Ming Qing Dang'an, above n 24, vol 9, at 100-101; Gao Taiwan fuzhi, above ch 2 n 57, at 249.

33 The above quote is taken from a paraphrase in Wen Ji Taiwan fanzheng zhi [A history of aboriginal management in Taiwan] (translated and adapted from Inō Kanori Taiwan bansei shi, Taiwansheng wenxian weiyuanhui, Taipei, 1957), at 68. The original decree is not extant.
} 
This decree reveals that the aborigines and settlers had been making arrangements regarding aboriginal land without the government's authority, or even knowledge. In the absence of clear government policy, settlers were left free to contract with aborigines and reclaim aboriginal land. The decree probably intended to bring "hidden land" onto the government register, but clearly it also purported to safeguard the aborigines' financial interest in the settler-aborigine transactions, and to generally protect the aborigines from Han exploitation. Although not expressly stated, this policy implied government recognition of aboriginal ownership over wasteland. Wang's decree was observed, as existing land reclamation permits from this time on often recorded that the land subject to grant did not encroach on aboriginal land. ${ }^{34}$

A late Kangxi period Circuit Intendant, Chen Bin (Kangxi 49-53), was the first to expound aboriginal rights over uncultivated land. Chen argued that each aboriginal village had its own boundaries that other villages could not violate. All land within the boundaries was the village property, and the villagers could use them as they liked. ${ }^{35}$ For a culture that put agriculture over any other occupations, a system that only recognised rights over cultivated land, and a deep-rooted tradition that all uncultivated lands were the government's "wasteland", Chen's opinion was well ahead of the common understanding of the time. Nevertheless, the government fully endorsed Chen's recommendation to "permanently forbid reclamation of aboriginal land", 36

Correlating with the new awareness of aboriginal land rights and efforts to protect them, land grants decreased from a few hundred jia per year before 1703 (Kangxi 42) to a few dozen jia every year between 1703 and 1722, with the exception of 1716 and 1717 when 102 and 129 jia of land was registered respectively. ${ }^{37}$ During the 20 years between 1703

\footnotetext{
${ }^{34}$ For example, see land reclamation permits and government notices collected in Dazu diaocha, above $\mathrm{n} 22$, at 2-4, issued between 1709 (Kangxi 48) and 1727 (Yongzheng 5).

${ }^{35}$ Chen Bin Chen Qingduangong wenxuan [Selected writings of Chen Bin] (TWWX 116), at 16.

${ }^{36}$ Ibid. There is no record of laws being made to this effect, but Lan Ping Tai jilüe, above ch 1 n 131, at 54 states that "in the past, reclamation of aborigines' land has been forbidden". Also see Shepherd Statecarft and Political Economy on the Taiwan Frontier, above "Introduction" n 35, at 247 and 257.

${ }^{37}$ See the statistics in Liu Chongxiu Fujian Taiwan fuzhi, above ch 1 n 28, at 129-134.
} 
and 1722 (Kangxi 42-61) only 840 jia of new land was registered, compared with 2,565 jia in 1685, and 7,669 jia in the 17 years from 1686 to 1702 (Kangxi 25-41).

Given the ban against reclamation of aboriginal land, the fact that new lands were reclaimed and registered, albeit in restricted amount, in the late Kangxi years suggests that the recognition of aboriginal land had at least some limits. Regulations never defined the term "aboriginal land". Despite his advocacy for aboriginal land rights, Chen at first did not think that all land belonged to the aborigines. He called for settler reclamation of “vacant land” (kuangdi 旷地), and stated that: ${ }^{38}$

Zhuluo County in the north covers over 2,300 li, Fengshan in the south covers over $600 \mathrm{li}$, and in the middle Taiwan County is over $50 \mathrm{li}$ from the east to the west. In between there is much vacant land [kuangdi 旷地], and it is a pity to leave it untouched. Residents in Zhangzhou and Quanzhou are only at the other side of the [Taiwan] Strait, and should be accommodated in the idle and vacant land...

Chen's statements suggest that while he recognised land that was actively controlled and used by aborigines was aboriginal land, he considered land that aborigines did not actively control to be as wasteland belonging to the government. After a few years of observation, however, Chen seemed to have concluded that all uncultivated land in Taiwan was in fact controlled and used by aborigines. In 1715 (Kangxi 54), Chen told the Kangxi Emperor that "there is no wasteland in Taiwan. Although there is much vacant land in the south and in the north, this is all aboriginal deer grounds". ${ }^{39}$ In this way Chen extended his recognition of aboriginal rights over all land. The government's recognition was not necessarily as extensive, given that small amounts of land were granted in the late Kangxi years.

Thus the government started to recognise aboriginal ownership over wasteland in Taiwan. However, because there was no clear definition of aboriginal land, officials relied on aboriginal claims to ascertain aboriginal land. If aborigines could control their territory and

\footnotetext{
${ }^{38}$ Chen, above n 35 , at 13 .

${ }^{39}$ Ding Zongluo Chen Qingduangong nianpu [A chronological biography of Chen Bin, 1825] (TWWX 207), at 80, “臺灣原無荒地; 南北路荒地雖多, 俱是土番鹿場”.
} 
enforce their rights over the land, their claims would be upheld. If no aborigine came forward to claim a piece of land, that land was not subject to protection against Han claims and fell into the category of government "wasteland".

\section{Temporary Policy Shift}

The ban against reclaiming aboriginal land was removed in 1724 (Yongzheng 2), when the Yongzheng Emperor decreed: ${ }^{40}$

If Taiwan aborigines' idle and vacant (xiankuang 閑曠) deer grounds are suitable for agriculture, order the local officials to publish notice that, the aborigines are free to lease ( $z u$ 租) [them] to settlers for cultivation.

The decree was then made a regulation. This decree has been seen as opening the floodgates to land reclamation by settlers, and hence as showing a shift from "quarantine" to a procolonisation policy. But in fact the recognition and protection of aboriginal land rights were not withdrawn at this time.

The issue of the decree accorded with the Yongzheng government's changing policy focus, which was not limited to Taiwan. The Yongzheng government initiated some important policies at both imperial and local levels, including expanding the agricultural base and major fiscal reforms to increase revenue for the central government. ${ }^{41}$ The Emperor explained the importance of land reclamation: ${ }^{42}$

The country has for long been peaceful, and the population is growing. The produce [of the land] is just enough [to support the people]. If there is a famine or bad harvest, people will have difficulty finding enough food. In the future when the population

\footnotetext{
${ }^{40}$ Taiwan shili, above ch $2 \mathrm{n}$ 64, at 43: “福建㗌灣各番鹿場閑曠地方可以墾種者, 令地方官曉諭, 聽各 番租與民人耕種”。

${ }^{41}$ See Madeline Zelin “The Yung-cheng Reign”, in Peterson (ed) The Cambridge History of China Volume

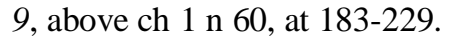

${ }^{42}$ Wenxian tongkao, above n 17, vol 3, at 1, “國家承平日久, 生齒殷繁, 土地所出僅可䝮給。倘遇荒歉, 民食維嘆。將來户口日增, 何以鴬業。惟開墾一事, 于百姓最有禆益。”
} 
continues to grow, what can people's livelihood be? Only land reclamation will benefit the people most.

Thus the Emperor extended the tax grace period for dry land to 10 years, and "several times decreed to encourage people to reclaim and cultivate land". ${ }^{43}$ Millions of acres of land were reclaimed during the Yongzheng reign, extending from the economic heartland of China to the distant provinces, as Han settlement was extended to the northwest and southwest of the empire. ${ }^{44}$ Against this background, it is not surprising that the government would have searched for ways to promote land reclamation in Taiwan as well. Once again, the lack of any Taiwan-specific policy is apparent.

The argument of a pro-colonisation official in Taiwan, Lan Dingyuan, also influenced policy change. Lan evaluated benefits of reclamation of aboriginal land, and suggested that the government require the aborigines to reclaim their vacant land, failing which the land should be opened to settlers. ${ }^{45}$ Although often seen as a pro-colonist, Lan did not deny the aborigines' prior ownership. He conceded that "if we talk about aboriginal land, the whole of Taiwan was taken from the aborigines" ${ }^{46}$ and suggested that settlers who reclaimed aboriginal land should assume the aborigines' tax burden as a kind of rent. ${ }^{47}$ Thus Lan accepted that compensation should be paid for land used by settlers. Although the amount might be small, paying compensation in principle recognised the aboriginal property rights.

The 1724 regulation was a lot more restrictive than Lan's suggestions. The wording of the regulation was neutral, and did not force or encourage the aborigines to open up the land. Further, although it appeared to be pro-colonisation if compared with the Kangxi government's ban, by allowing only lease but not sale, the regulation preserved, or at least was intended to preserve, a safeguard for the aborigines. In fact, by making existing underthe-table arrangements between settlers and aborigines more transparent, it may have provided better protection to the aborigines.

\footnotetext{
${ }^{43}$ At 1 and 29, “是以屡頒諭旨, 勸民鮭種”.

${ }^{44}$ Zelin, above n 41, at 215-218; Rowe "Social Stability and Social Change", above ch 2 n 17, 473, at 484.

${ }^{45}$ Lan, above n 36, at 54.

${ }^{46}$ Ibid.

${ }^{47}$ Ibid.
} 
The regulation did advance land reclamation, as the local government implemented it zealously. The Taiwan Circuit Intendant, Zhang Sichang, issued decrees encouraging settlers to negotiate with aboriginal villages for land reclamation rights, pay agreed amounts of money or other goods and annual grains, and then apply for land reclamation permits. ${ }^{48}$ As a result, the Yongzheng era saw increasing land grants. In 1728 (Yongzheng 6), the area of newly registered land in Taiwan suddenly rose sharply to 16,337 jia, compared to $156 \mathrm{jia}$ in 1724 (Yongzheng 2) and 129 jia in 1727 (Yongzheng 5). ${ }^{49}$ Over the next two years new land registration remained high, with 3,351 jia and 1,736 jia of land being added to the register in 1729 and 1730 (Yongzheng 7 and 8) respectively. During the 13 years of the Yongzheng reign, 22,222 jia of land was added to the register, about double of the 11,074 jia of newly registered land during 40 years of the Kangxi reign. ${ }^{50}$ Even if the register did not accurately reflect the land that had been reclaimed because of "hidden land" issues, the figures revealed a sharply rising trend. ${ }^{51}$

Looked at objectively, the Yongzheng government continued to recognise aboriginal land ownership, and afforded a degree of protection to the aborigines. However, the removal of the reclamation ban meant that protection was less vigorous, and the increased reclamation activities did have adverse effects on the aborigines' lives. The relaxed protection was tightened again under the Qianlong government.

\section{A Return to Protection}

\section{A Protection: Efforts and Results}

The Qianlong government continued to encourage land reclamation at the imperial level. By the mid-Qianlong reign, land reclamation in the empire was mostly taking place at the margins of existing reclaimed land. ${ }^{52}$ In the hilly province of Fujian, provincial regulations made in 1759 and 1760 (Qianlong 24 and 25) encouraged reclamation of marginal land and

\footnotetext{
48 See one of Zhang's decrees, issued in 1734 (Yongzheng 12), in Ming Qing dang'an, above n 24, vol 16, at 237.

49 See Liu, above n 37, at 135.

${ }^{50}$ See the statistics in ibid, at 129-137.

${ }^{51}$ It should be noted, however, that the government's policies encouraging land registration also contributed to this increase. See discussions in Ka Fantoujia, above "introduction" n 39, at 106-113.

52 Zelin, above n 41, at 215.
} 
exempted pieces of land smaller than one $m u$ from tax, relying on imperial decrees issued in 1740 and 1741 (Qianlong 5 and 6). ${ }^{53}$ However, in Taiwan, the government reverted to the Kangxi government's stance and tightened the protection of aboriginal land. A regulation of the Ministry of Households stipulated that: ${ }^{54}$

Han villains in Taiwan who $p u$ (贌 lease) ${ }^{55}$ acculturated aborigines' wasteland are punishable according to the law of 'theft of land through unauthorised cultivation'; those who reclaim land in the non-acculturated aboriginal territory are punishable according to the law of breach of border control. The land is to be returned to the aborigines.

During the Qianlong reign, laws and policies repeated this principle.

\section{Acculturated aboriginal land}

The renewed protection was through regulations which forbade settler reclamation, cultivation, lease or purchase of aboriginal land. In addition, efforts were made to identify and return to aborigines land that had been illicitly occupied, leased or purchased by settlers. As shown in Chart 14, between 1737 and 1766 (Qianlong 2-31), the Emperor approved seven recommendations by the Fujian provincial government or the Taiwan Censor, with one of them (1746) being made a formal regulation. ${ }^{56}$ The recommendations were in similar terms. Three of the recommendations explicitly forbade purchase or lease of aboriginal land (1737, 1738 and 1766), two (1746 and 1750) stated that aboriginal land was to be cultivated by aborigines only, and five recommendations (1737, 1738, 1746, 1760 and 1766) ordered the return of aboriginal land to aborigines that had been leased to, illegally occupied by or otherwise illicitly reclaimed by settlers. Three recommendations even prescribed punishment for breaches. On four occasions (1738, 1746, 1758 and 1766) the government investigated and demarcated boundaries between settlers' land and

\footnotetext{
${ }^{53}$ Fujian shengli [Regulations of Fujian Province] (TWWX 199), at 451-454.

54 “薹灣奸民. 私贌熟番土地者, 依盗耕本律問擬; 於生番界內私墾者, 依越度關塞問擬, 田仍歸 番”. Hubu zeli [Regulations of the Ministry of Households, cir 1865] (Chinese Text Project, www.ctext.org), vol 10 , at 30 ..

${ }^{55} \mathrm{Pu}$ is a type of land transaction that will be further discussed in ch 4 .

56 Gaozong shilu, above ch 2 n 24, at 9, 51, 79-80, 126-127, 147-149; Dazu diaocha, above n 22, at 319-320.
} 
aboriginal land. ${ }^{57}$ The repeated attention demonstrates the government's determination to protect aboriginal land rights.

As explained in Chapter 1 (see also Chart 14), the laws were made largely through recommendations of officials and acknowledgement or approval by the central government or the Emperor. There was no clear definition of key terms or attention to conflicting regulations. As such the laws were not always consistent and sometimes sent mixed messages. The 1737 and 1738 laws, although they forbade leasing and purchase of aboriginal land, nevertheless recognised previous land transactions and allowed registration of aboriginal land that had already been sold to settlers. The 1746 regulation required settlers to "return land to the aborigines". The 1746 and 1750 provisions both specified that aboriginal land was to be cultivated by aborigines only. The 1760 policy set out to implement the 1746 regulation, yet it only required returning land for the aborigines to manage, which meant the aborigines continued in the capacity of landlords. In such cases the lease relationship was one in which the aborigines received a set amount of rent but lost any substantive rights over the land. ${ }^{58}$ The true "return" of land was limited only to land beyond the non-acculturated aboriginal boundaries. The 1760 policy was self-contradictory because the 1746 regulation explicitly required cultivation by aborigines, not just management by aborigines. Hence the 1760 policy relaxed the requirement, and rectified illicit reclamation of 20 pieces of land, which were mostly leased by aborigines to settlers. ${ }^{59}$

The 1766 policy overrode the 1760 provision and required return of land to the aborigines. However, as the method of law-making was not systematic, the 1760 provision was not revoked in 1766. An obscure 1767 provincial decision continued the 1760 approach, and allowed lease of aboriginal land at the large rent rate of 4 shi and 8 shi per jia for dry land and wetland respectively. ${ }^{60}$ The Taiwan Circuit Intendant, Zhang Ting, issued a decree in

\footnotetext{
${ }^{57}$ A further often cited regulation was that in 1744 (Qianlong 9) which required investigation of estates held by military officers and return of "settlers" land to settlers, aboriginal land to aborigines". This in effect would have protected aboriginal land rights, but the policy direction was not specifically aboriginal land.

58 This type of lease, called "large rent" (dazu 大租), will be discussed further in ch 4.

${ }^{59}$ Gaozong shilu, above n 56, at 126-127.

${ }^{60}$ Shepherd, above n 36, at 290-291, quotes a fragment of a 1767 decree in Taiwan tochi kankō ippan [Overview of Taiwan land tenure] vol 2, at 125. The fragment does not indicate who issued the degree, but a
} 
1768 to implement the 1767 decision. ${ }^{61}$ This approach was directly contrary to the 1766 policy, and shows the loopholes in the law-making and implementation mechanisms.

The 1766 policy required compilation of records of land belonging to aborigines. At the same time, two positions of aboriginal affairs sub-prefects were created to protect aboriginal wellbeing. These sub-prefects' duties included investigating unfair settleraborigine land transactions and ensuring return of aboriginal land to aborigines, attending to cases where settlers married aboriginal women and occupied aboriginal property, and impeaching government officials or clerks who oppressed aborigines. ${ }^{62}$ Very likely the problems were dealt with by the aboriginal affairs sub-prefects effectively, and no further imperial law or policy was made concerning acculturated aboriginal land after 1766.

In summary, the Qianlong government was determined and vigorous in protecting acculturated aboriginal land rights, but because of the inherent problem in the mechanism of law-making, the regulations were not always consistent, and sometimes left room for misinterpretation and errors in their implementation.

case note in Dazu diaocha, above n 22, at 648-649 noted that in Qianlong 32 (1767) the provincial government approved such rent rates.

${ }^{61}$ See Zhang's decree in Sifa cankao, above ch 2 n 122, vol 1A, at 293-294.

62 See Dan Xin dang'an, above "Introduction" n 56, vol 17, at 189-190. Song, above n 23, at 147, listed 10 responsibilities of the sub-prefects, which cover all aspects of aboriginal affairs. 
Chart 14 Laws/Policies Protective of Aboriginal Land Rights (1684-1795)

\begin{tabular}{|c|c|c|c|}
\hline Year & Law & Law-making body & Source \\
\hline $\begin{array}{l}\text { About } \\
1704 \\
(\text { KX43) }\end{array}$ & $\begin{array}{l}\text { Officials to investigate whether aboriginal land } \\
\text { would be encroached upon and details of aborigine- } \\
\text { settler transactions before issuing a land reclamation } \\
\text { permit. }\end{array}$ & \begin{tabular}{|lr} 
Taiwan & Circuit \\
Intendant & Wang \\
Minzheng & \\
\end{tabular} & $\begin{array}{l}\text { No direct } \\
\text { record. }\end{array}$ \\
\hline $\begin{array}{l}\text { By } 1722 \\
\text { (Late KX } \\
\text { reign) }\end{array}$ & Reclamation of aboriginal land not allowed. & $\begin{array}{l}\text { Likely to be central } \\
\text { government law }\end{array}$ & $\begin{array}{l}\text { No direct } \\
\text { record. }\end{array}$ \\
\hline $\begin{array}{l}1724 \\
(Y Z 2)\end{array}$ & $\begin{array}{l}\text { Aborigines allowed to lease land to settlers for } \\
\text { reclamation. }\end{array}$ & $\begin{array}{l}\text { Imperial decree. Was } \\
\text { made a regulation. }\end{array}$ & $\begin{array}{l}\text { Taiwan shili, } \\
\text { at } 43 \text {. }\end{array}$ \\
\hline $\begin{array}{l}1737 \\
(\mathrm{QL2})\end{array}$ & $\begin{array}{l}\text { Purchase of aboriginal land forbidden; settlers to } \\
\text { return aboriginal land that they illicitly reclaimed. } \\
\text { Land that settlers purchased and registered for tax } \\
\text { before this to be surveyed and compiled into a } \\
\text { special record. Demarcate boundaries of aboriginal } \\
\text { land and settlers' land. }\end{array}$ & $\begin{array}{l}\text { Imperial approval of } \\
\text { Taiwan Censor's } \\
\text { recommendation }\end{array}$ & $\begin{array}{l}\text { Gaozong } \\
\text { shilu, at } 9 .\end{array}$ \\
\hline $\begin{array}{l}1738 \\
(\mathrm{QL} 3)\end{array}$ & $\begin{array}{l}\text { To recognise previous sales and allow registration of } \\
\text { those not yet been registered. Land reclaimed } \\
\text { without support of a land deed to be returned to } \\
\text { aborigines. Demarcate boundaries between settlers } \\
\text { land and aboriginal land. Reiterate the ban of lease } \\
\text { and purchase. }\end{array}$ & $\begin{array}{l}\text { Imperial approval of } \\
\text { Governor-General's } \\
\text { recommendation. }\end{array}$ & $\begin{array}{l}\text { Dazu } \\
\text { diaocha, at } \\
\text { 319-320. }\end{array}$ \\
\hline $\begin{array}{l}1746 \\
(\mathrm{QL11})\end{array}$ & $\begin{array}{l}\text { Aboriginal land to be cultivated by aborigines only; } \\
\text { settlers who leased aboriginal land to return land to } \\
\text { aborigines and subject to punishment; those who } \\
\text { reclaimed land in non-acculturated aborigines' } \\
\text { territories to be punished; clarify boundaries } \\
\text { between aborigines' and settlers' lands. }\end{array}$ & $\begin{array}{l}\text { Imperial approval of } \\
\text { Governor-General's } \\
\text { recommendation; was } \\
\text { made an imperial } \\
\text { regulation. }\end{array}$ & $\begin{array}{l}\text { Taiwan shili, } \\
\text { at } 44 \text {. Also } \\
\text { see Gaozong } \\
\text { shilu, at } 51 \text {. }\end{array}$ \\
\hline $\begin{array}{l}1750 \\
(\mathrm{QL15})\end{array}$ & $\begin{array}{l}\text { To clarify non-acculturated aboriginal boundaries } \\
\text { and police illegal reclamation; acculturated } \\
\text { aborigines' land to be cultivated by aborigines only. } \\
\text { To punish breaches. }\end{array}$ & $\begin{array}{l}\text { Imperial approval of } \\
\text { Governor-General's } \\
\text { recommendation. }\end{array}$ & $\begin{array}{l}\text { Gaozong } \\
\text { shilu, at 79- } \\
80 .\end{array}$ \\
\hline $\begin{array}{l}1758 \\
\text { (QL 23) }\end{array}$ & $\begin{array}{l}\text { To clarify and demarcate boundaries between lands } \\
\text { belonged to aborigines and settlers. }\end{array}$ & $\begin{array}{l}\text { Imperial approval of } \\
\text { Governor-General's } \\
\text { recommendation. }\end{array}$ & $\begin{array}{l}\text { Gaozong } \\
\text { shilu, at } 118 .\end{array}$ \\
\hline $\begin{array}{l}1760 \\
(Q L 25)\end{array}$ & $\begin{array}{l}\text { To clarify non-acculturated aboriginal boundaries; to } \\
\text { apply the } 1746 \text { regulation and order return of land to } \\
\text { aborigines, but Han settlers who leased aborigines' } \\
\text { land were allowed to continue as tenants and pay } \\
\text { rents to aborigines; unreclaimed aboriginal land to } \\
\text { be reclaimed to support border guards; land situated } \\
\text { beyond aboriginal boundaries returned to aborigines. }\end{array}$ & \begin{tabular}{|l|} 
Imperial \\
acknowledgement of \\
provincial regulation.
\end{tabular} & $\begin{array}{l}\text { Gaozong } \\
\text { shilu, at } 126- \\
127 .\end{array}$ \\
\hline $\begin{array}{l}1766 \\
(\mathrm{QL3} 3)\end{array}$ & $\begin{array}{l}\text { To investigate and demarcate boundaries between } \\
\text { aboriginal land and settlers land; encroached } \\
\text { aboriginal land returned to aborigines; land that was } \\
\text { illegally leased against regulations returned to } \\
\text { aborigines; to compile records of land belonged to } \\
\text { aborigines; future sale or lease of aboriginal land } \\
\text { would result in confiscation of land and punishment } \\
\text { of purchaser/leasee (settlers); forbade reclamation } \\
\text { near non-acculturated aboriginal boundaries. }\end{array}$ & $\begin{array}{l}\text { Imperial approval of } \\
\text { Governor-General's } \\
\text { recommendation. }\end{array}$ & $\begin{array}{l}\text { Gaozong } \\
\text { shilu, at 147- } \\
149 .\end{array}$ \\
\hline
\end{tabular}


Chart 15 Main Points of the Land Policies of the Qianlong Government

\begin{tabular}{|l|l|l|l|l|l|l|}
\hline $\begin{array}{l}\text { No } \\
\text { sale/lease }\end{array}$ & $\begin{array}{l}\text { Cultivation } \\
\text { by } \\
\text { Aborigines }\end{array}$ & $\begin{array}{l}\text { Mark } \\
\text { boundaries }\end{array}$ & $\begin{array}{l}\text { Return } \\
\text { land }\end{array}$ & Punishment & $\begin{array}{l}\text { Un-acculturated } \\
\text { aborigine } \\
\text { boundaries }\end{array}$ & Other provisions \\
\hline 1737 & & 1737 & 1737 & & & $\begin{array}{l}\text { Recognised past } \\
\text { purchases }\end{array}$ \\
\hline 1738 & & & 1738 & & & As above \\
\hline & 1746 & 1746 & 1746 & 1746 & 1746 & \\
\hline & 1750 & & & 1750 & 1750 & \\
\hline & & 1758 & & & 1760 & $\begin{array}{l}\text { Implemented } \\
1746 \text { regulation, } \\
\text { but allowed } \\
\text { current lease to } \\
\text { continue }\end{array}$ \\
\hline & & & 1760 & & & \\
\hline
\end{tabular}

\section{Non-acculturated aboriginal land}

As mentioned, government regulations prescribed that land reclaimed beyond the nonacculturated aboriginal boundaries had to be returned to aborigines. Breach of this rule risked severe punishment. In practice the government did not always adhere to the principle, resulting in expansion of settlement to the border areas.

The ban against reclamation beyond the boundaries applied only to Han settlers, and did not apply to acculturated aborigines. ${ }^{63}$ As the government viewed the aborigines as the original owners of all land in Taiwan, it restricted land reclamation by Han settlers who were intruders, but was less concerned with the fact that different areas of land belonged to different aboriginal groups. Because of the exception made for acculturated aborigines, it was not a complete ban against reclamation in the non-acculturated aboriginal territories. This in practice gave Han settlers the opportunity to reclaim land near or beyond the boundaries.

As Han settlement expanded, the government adjusted aboriginal boundaries accordingly, provided that there was no security threat from the non-acculturated aborigines. As Chart

${ }^{63}$ See the Taiwan Prefect's report in 1790 (Qianlong 55) in Tai'an jiaji, above ch $1 \mathrm{n}$ 135, at 30 “臺灣束界 内山，本多荒土，禁民越墾，準令熟番打牲耕種”。 
15 shows, four of the recommendations $(1746,1750,1760$ and 1766) required redrawing of the aboriginal boundaries or forbade reclamation of land beyond those boundaries. On each occasion, the boundaries were pushed towards the foothills, and the settlement areas expanded. $^{64}$

When determining whether to place an area within the boundaries and acquiesce in reclamation, or to place it beyond the boundary lines and exclude it from reclamation, the government's principal consideration was the distance of that area from non-acculturated aborigines' territories. This arose from the government's policy of reducing conflicts, which were usually caused by the non-acculturated aborigines being irritated by Han encroachment and then killing settlers in retaliation. ${ }^{65}$ Where there was no such security threats, the government acquiesced in illegal land reclamation or transactions and allowed those lands to be registered for taxation. ${ }^{66}$ For example, in 1755 (Qianlong 20), the Ministry of Households discussed the Fujian-Zhejiang Governor-General's report concerning Shuishalian and the Quantoumu mountain. Both had formerly been marked as settler-forbidden areas, but as it was found that they were about $30 \mathrm{li}$ away from the nonacculturated aboriginal villages, the central government approved registration of the illicitly reclaimed lands, and allowed reclamation of the remaining land, measuring about 1,104 jia. $^{67}$

Similarly, in 1788 (Qianlong 53), following extensive investigation, the government discovered 11,204 jia of land near or beyond the aboriginal boundaries, which had been purchased or leased from the aborigines and reclaimed by settlers. The government retrospectively approved the illegal transactions between settlers and aborigines, and allowed the settlers to register the lands for taxation purposes. ${ }^{68}$ Some lands, in Jijipu, Tuzaikeng, Sandiao and Langqiao, were apparently illicitly reclaimed (siken 私墾) without

\footnotetext{
${ }^{64}$ See Lin and Wei "Lin Shuangwen shijian qian de Taiwan bianqu tuxiang”, above ch 2 n 73, at 73.

65 At 67.

66 At 73; Shepherd, above n 36, at 279-284.

${ }^{67}$ Gaozong shilu, above n 56, at 111.

${ }^{68}$ At 611.
} 
any consent from aborigines. The government nevertheless decided to allow registration of these lands, presumably because the reclamation was uncontested by aborigines. ${ }^{69}$

The government's inconsistent policies can be explained by two main factors. The first factor was the absence of any clear definition of aboriginal land. The second factor was that the government's overriding concern was order and security, not a concern for aboriginal land rights as such. Although the Qianlong government made significant efforts to protect aboriginal land rights, and regulations often forbade reclamation of aboriginal land, the concept of "aboriginal land" was quite elastic. Where reclamation of land did not cause protest from the plains aborigines, or would not provoke retaliation by the mountain aborigines, the government was quite happy to exclude the land from the category of "aboriginal land". Protection of aboriginal land rights was a means to an end.

Despite the inconsistent policies concerning both acculturated and non-acculturated aboriginal land, the Qianlong government's efforts restored political relationships between the government and the aborigines. The relationships had deteriorated during the Yongzheng reign. During the Qianlong reign, the 93 villages of acculturated aborigines never rebelled, ${ }^{70}$ and the number of non-acculturated aboriginal villages that submitted themselves to the government authority increased to over 200 .

\section{$B$ Aboriginal Colonies}

The establishment of aboriginal colonies (fantun 番屯) in 1788 (Qianlong 53) was an important event during the Qing rule of Taiwan. Its importance lay not in protection of aboriginal land as such, but in the government's willingness to trust the aborigines over Han settlers, and in the system's lasting effects in preserving aboriginal society.

\section{$1 \quad$ The tuntian system}

Tuntian 屯田 was a land reclamation system used throughout Chinese history where the government organised military soldiers to reclaim land, or organised labourers in a quasi-

\footnotetext{
69 Ibid.

${ }^{70}$ Song, above n 23, at 148.
} 
military structure to reclaim large areas of land. ${ }^{71}$ The system of tuntian originated in the Western Han Dynasty (202BC-8AD). After Emperor Wu of the Han Dynasty defeated the nomads in the northwest of China, he sent military forces to guard the borders as well as to reclaim and farm the land. ${ }^{72}$ It was not only a method for the soldiers to support themselves, but also an organised and efficient way to reclaim land and guard against invasion. ${ }^{73}$ Tuntian was used by subsequent dynasties to varying extents, and became a common approach to manage frontiers in the Chinese imperial tradition. As the system developed, its application was not limited to soldiers and the purpose went beyond guarding borderlands. At times tuntian involved civilians and focused more on land reclamation than on border defence. For example, the military farms in Taiwan during the Zheng period were a form of tuntian, and their main purposes was to support the soldiers.

The Qing Dynasty continued with the tradition of tuntian. To increase land reclamation and agriculture activities in Xinjiang, the Qing government organised five types of tuntian, respectively by military forces, Han civilians, the local Hui people, bannermen, and exiled criminals. ${ }^{74}$

The difference between tuntian and ordinary reclamation lay in that tuntian was state organised land reclamation system where people belonged to military or quasi-military structures. It usually occurred in frontier areas, and involved mobilising people from the heartland to the frontiers, organising them into regiments and allocating them certain amount of land.

\section{Aborigines as military reserves}

The aboriginal colonies in Taiwan were a type of tuntian, but the purpose was the special one of building aboriginal military reserves.

\footnotetext{
${ }^{71}$ Tang Qiyu Lidai tunken yanjiu [A research on land reclamation through tuntian in the various dynasties] (Zhengzhong, Shanghai, 1947), at 5.

72 Zhang Junyue Lidai tuntian kao [Study of tuntian in the various dynasties] (Shangwu, Beijing, 1939 ), at 4. 73 At 2.

74 Yang Qingdai Xinjiang diqu falü zhidu jiqi bianqian yanjiu, above ch 2 n 134, at 171; Peng Qingdai tudi kaiken shi, above ch 1 n 132, at 209-215.
} 
The establishment of aboriginal colonies was prompted by the Lin Shuangwen uprising, which broke out in 1786 (Qianlong 51). This was the second large scale Han uprising in Qing Taiwan, following the Zhu Yigui uprising in 1721. However the 1721 uprising was suppressed within a month, while the 1786 uprising was much more serious and lasted for over a year. Within one month after it broke out, the rebels took Zhanghua and Zhuluo counties, and threatened the prefectural capital. The Qing government sent troops from the mainland to suppress the uprising. Among these troops were tunlian (屯練 militia) forces from Hunan, Guizhou, Guangxi and Sichuan provinces. ${ }^{75}$ After the rebellion was crushed, the contribution of the tunlian forces inspired the creation of aboriginal colonies in Taiwan.

The rebellion prompted the Emperor to restructure the military forces in Taiwan. At first the Emperor considered replacing half of the regular military forces with Han Chinese (yimin 義民 loyal/faithful Chinese subjects), and to use some of the confiscated land for their upkeep. However, the Grand Councillor, Fukangan, who had led the successful suppression of the rebellion, was concerned about the loyalty and discipline of the Chinese, because the uprising itself was triggered by conflicts among settler communities originating from different regions of China. ${ }^{76}$ In Taiwan, most settlers were Hoklos (Fulao 福佬) from Zhangzhou and Quanzhou of Fujian Province, and the rest were the Hakkas (Kejia 客家) from Guangdong Province. Although they were all Han Chinese, the settlers formed diverse sub-ethnic communities, and their rivalries often resulted in communal strife (xiedou 械鬥), a phenomenon in the late $18^{\text {th }}$ and early $19^{\text {th }}$ centuries Taiwan. ${ }^{77}$ This rivalry was manifested in the Lin Shuangwen uprising, where settlers originating from Quanzhou and the Hakkas assisted the government to suppress the Zhangzhou-led uprising. The government also mobilised the plains aborigines to help suppress the uprising, and the mountain aborigines helped capture Lin Shuangwen in response to the government's

\footnotetext{
${ }^{75}$ Gaozong shilu, above n 56, at 586.

${ }^{76}$ At 603-604.

${ }^{77}$ See, in general, Harry J Lamley "Subethnic Rivalry in the Ch'ing Period" in Emily Martin Ahern and Hill Gates (eds) The Anthropology of Taiwanese Society (Standard University Press, California, 1981) 282-318; Shepherd, above n 36, at 310-319.
} 
promise for a reward. Ethnic relations in Taiwan were a complicated web of competing interests and rivalries, not a simple matter of "Han" versus "aborigines".

Given the complicated rivalry among the different Han groups and the role played by the plains aborigines in the suppression of the uprising, Fukangan proposed that the aborigines be organised into companies ${ }^{78}$ to supplement the regular army in Taiwan, utilising the tradition of tuntian and following the Sichuan tunlian precedent. ${ }^{79}$

Following Fukangan's plan, in 1788 the government established 12 quasi-military companies, positioned near the regular armies at either strategic locations or the borders with mountain aborigines. The 12 companies comprised 4,000 strong and brave male aborigines from the 93 plains aboriginal villages. Large villages were used as the bases of the companies, incorporating members from nearby villages. Each company was made up of 300 or 400 members, and was led by a lieutenant (waiwei 外委). In addition there were two captains (qianzong 千總) and four deputy captains (bazong 把總) over the 12 companies. ${ }^{80}$

Although the aboriginal warriors were enrolled in the companies, they were not required to relocate to the tun location. There was no centralised training or work. The aborigines performed their tasks based in their own villages, and were mobilised into companies only when necessary. ${ }^{81}$

The choice of the aborigines as military reserves shows that in Taiwan, not only the ethnic and sub-ethnic relations were complex, but also that the government's attitude towards different ethnic groups was not straightforward. It was not a case of government supporting colonists to the detriment of the aborigines. Rather the government preferred the aborigines over the Han settlers as its ally. This preference for the aborigines partly explained the government's protection of aboriginal land rights.

\footnotetext{
${ }^{78}$ Here "company" is in the quasi-military organisational sense, not commercial sense.

${ }^{79}$ Gaozong shilu, above n 56, at 611.

80 Ibid.

${ }^{81}$ Tai'an jiaji, above n 63, at 2-3.
} 


\section{The land}

Since the companies were based on the tradition of tuntian, it was necessary to find land for the upkeep of the company members. As the western plains had been mostly reclaimed by settlers, and the mountain areas were occupied by mountain aborigines, only places near the mountain aboriginal boundaries were available. In 1784 (Qianlong 49), the government had surveyed land near the boundaries, following the surveys in 1750 and 1760 (Qianlong 15 and 25), as part of the clarification of aboriginal boundaries. The survey discovered 11,204 jia of illegally reclaimed land, and 5,441 jia of vacant land not yet reclaimed. Before the government made a decision about these lands, the rebellion broke out. ${ }^{82}$ Following the plan to establish aboriginal colonies, the land was resurveyed. The new survey found an additional 3,735 jia of reclaimed land, and a total 5,691 jia of unreclaimed land.

The government allocated the unreclaimed land to the 4,000 aboriginal warriors. Depending on the distance from their respective villages, each warrior received one to 1.6 jia of land. The lieutenants and captains received slightly more. This land was called “upkeep land” (yangshan pudi 養贍埔地), since it was for the upkeep of the company members. The government imposed rents on the reclaimers of the 3,735 jia of illicitly reclaimed land, ${ }^{83}$ and used the rent to pay the warriors' monthly allowance. To distinguish it from the upkeep land, this land was called "company land" (tundi 屯地).

The concepts of "upkeep land" and "company land" were quite different. Company land was part of the government estate. ${ }^{84}$ The government set rentals, appointed people to collect the rent, and distributed it to company members. The nature of upkeep land was more complicated. One legal scholar has defined it as "inheritable property of the company individuals" (tunding de shixiye 屯丁的世襲業), of which the individuals had ownership. ${ }^{85}$ This view is worth re-examination. In theory the upkeep land was allocated to individual company members. When they left the company due to old age, health issues or death, the

\footnotetext{
${ }^{82}$ At $1-2$.

83 The 11,204 jia of reclaimed land surveyed in 1784 fell outside the aboriginal colony system and was dealt with separately. See ibid, at 8-9. Also see discussed in Section A2 of this Part.

${ }^{84}$ Tai Yen-hui Qingdai Taiwan zhi xiangzhi [The administration at the town and village levels in Qing Taiwan] (Lianjing, Taipei, 1979), at 487, is also of this view.

${ }^{85}$ At 490.
} 
replacing person would inherit the land. Usually the incoming person was chosen from the outgoing member's family or close relatives, ${ }^{86}$ but this was different from automatic succession by a member's family or descendants. In reality, aborigines from the same village often managed their land together. Regulations specified that the land was for the aboriginal warriors to "cultivate themselves" (zixing gengzhong 自行耕種). ${ }^{87}$ If the aborigines dianmài (典賣 pledged or sold) the land, the purchaser was liable to return the land to the village to which the aboriginal warrior belonged, along with other punishments. ${ }^{88}$ Therefore the upkeep land essentially belonged to the village of the aboriginal warriors, rather than the individual aborigines or the tun companies.

Although the aborigines were allocated the land as an aspect of the military design, in the subsequent century the companies were mobilised only 18 times, half of which were to put down Han banditry or communal strife, and half against the non-acculturated aborigines in the late Qing period. ${ }^{89}$ The allocation of upkeep land and the distribution of monthly allowance from company land rental were seen by later officials as a reward to the aborigines for their support to the government during the 1786 uprising, as well as a way to guard the aboriginal boundaries. ${ }^{90}$ The establishment of aboriginal colonies hence went a step further than protecting aboriginal land, as the government allocated to the acculturated aborigines land that they did not have - the land bordered the aboriginal boundaries and likely belonged to the non-acculturated aborigines who had retreated further into the mountains.

To some extent, the organisation of the acculturated aborigines into companies was similar to that of organising the Manchus into banners. Although only 4,000 aboriginal warriors were chosen for the companies, the aboriginal families and villages formed a closed pool from which the warriors were drawn. Just like the banner system had preserved the Manchu identity, the system of aboriginal companies helped to preserve the acculturated aborigines'

\footnotetext{
${ }^{86}$ Tai'an jiaji, above n 63, at 18 and 21.

${ }^{87}$ Taiwan shili, above n 40, at 43.

${ }^{88}$ Ibid.

${ }^{89}$ Shepherd, above n 36, at 357.

${ }^{90}$ For example, see Liu Zhuangsugong zouyi, above ch 2 n 129, at 306.
} 
identity, even after they had lost their cultural distinctiveness. The protection of "upkeep land" was similar to the protection of banner land. In both cases the government forbade alienation and, if the regulations were breached, frequently ordered the return or redemption of land. ${ }^{91}$

\section{$V$ The Government Becomes Proactive}

This Part concerns the period 1800-1874. In the $19^{\text {th }}$ century some Qing officials reverted to the traditional view that the Emperor had the ultimate title over all land within the realm. A Taiwan Circuit Intendant, Xu Zonggan (1848-1853), said "once they submitted, the aborigines are our people, and the land is our land". ${ }^{92}$ In 1871 (Tongzhi 10), in a decree ordering protection of aboriginal land, the Aboriginal Affairs Sub-prefect of the Northern Circuit stated that "the Taiwan aboriginal villages, at the beginning of their submission, were granted land and rental property by the grace of the Emperor". ${ }^{93}$ These views were based on the old assumption that the Emperor owned all land within the realm, and the aborigines surrendered their land once they had submitted themselves to government authority.

Corresponding to the government's changing attitude towards settlement in Taiwan since the Jiaqing reign, officials' approaches towards aboriginal land became proactive. This was demonstrated once again in the cases of Gamalan and inner Shuishalian. In contrast to previous government's efforts to exclude aboriginal land from settler reclamation, and moving away from a policy of being the adjudicator between settlers and aborigines over land disputes, the government adopted proactive policy and took control of land allocation.

\section{A Gamalan}

After establishing administration in Gamalan in 1811, the government distributed the land among settlers and aborigines, even though it recognised that the land was aboriginal land.

\footnotetext{
${ }^{91}$ For protection of banner land, see Zhao and Chen, above n 5, at 64; Zhang Qingchao fazhishi, above "Introduction" n 30, at 247-250.

${ }^{92}$ See Ding Zhi Tai bigaolu, above ch 2 n 106, at 279.

${ }^{93}$ Sifa cankao, above n 61, vol 1A, at 299.
} 
The Gamalan plain was divided into two parts by the Zhuoshui River. North of the river was called “the Western Part" (xishi 西勢) and south of the river “the Eastern Part" (dongshi 東勢). Before government administration was established, Han settlement was concentrated at the Western Part. There were 20 aboriginal villages in the Western Part, with 2,277 aborigines. Settlers had reclaimed all land in the Western Part apart from one area called Shalunpu. The government recognised that some land had to be reserved for the aborigines' livelihood, and stipulated Shalunpu to be the aborigines' perpetual property. Settlers were not allowed to encroach there. Thus Shalunpu was a kind of aboriginal reserve. The Eastern Part had 16 aboriginal villages, with a population of 3,307. Settlers only reclaimed a small proportion of the Eastern Part. The government stipulated that one $l i$ of land around small villages and two $l i$ of land around large villages were reserved for aborigines. ${ }^{94}$ The reserves were in addition to land that was already under cultivation by the aborigines.

While the settlers were forbidden to lease land that was under aboriginal cultivation, the government allowed the reserved land to be leased to settlers. In fact, the government allocated the reserved land among the settlers, who were required to pay an annual rent of 4 shi of grain per jia. In Taiwan, the prevalent "large rent" (dazu 大租) rate was 4 shi per jia for dry land, but once the land was developed into paddy land, the rent rate was increased to 8 shi per jia. The stipulation of rent rates through government action, as opposed to leaving it to the parties concerned to reach agreements, resulted in the aborigines losing the opportunity to raise the rent in the future when the land was developed into paddy land. Another problem with large rent, as will be discussed in Chapter 4, is that the lessor in fact retained only the right to receive the fixed amount of rent, and lost any other rights over the land.

The government did not stipulate compensation or rent for land beyond the reserved areas. The land that settlers had reclaimed in the Western Part before government intervention

\footnotetext{
${ }^{94}$ Ke Gamalan zhilüe, above ch 1 n 134, at 141-142. "Small villages" and "large villages" were not defined. The village size ranged from just under 100 people to over 400 people. See Yao Dongcha jilüe, above ch $2 \mathrm{n}$ 81 , at 80-82.
} 
measured over 2,400 jia. No lease agreement about this area of land is available, although records mention in passing that settlers had leased the land, often unfairly or fraudulently. ${ }^{95}$ After the incorporation, the government allowed the settlers to register this land for taxation, and did not concern itself with whether the aborigines had been compensated.

Unreclaimed land in the Eastern Part measured 2,538 jia, and this was taken away from the aborigines and allocated to the settlers. The Emperor's decree of 1820 (Jiaqing 15) only mentioned that "as to those uncultivated lands, investigate the land boundaries. [Define] which part is for which group of settlers to reclaim, and which part is for aboriginal villagers to reclaim. [The land] must be divided fairly so as to avoid disputes". ${ }^{96}$ No compensation or rent was mentioned for this land either.

The weak position of the aborigines' vis-à-vis the settlers might have been one reason of the government's proactive and high-handed approach. As at the time of incorporation, the settler population was over 45,000 , and the aboriginal population was under $6,000 .{ }^{97}$ In 1810, the Fujian-Zhejiang Governor-General visited Gamalan. The aboriginal village heads, seeking government protection from the settlers' intrusion, presented their population information and petitioned to be incorporated into the empire. ${ }^{98}$ The government seemed to take this as amounting to a surrender of land rights, and took charge of the land in Gamalan. The establishment of aboriginal reserves was designed as a kind of protection, and the management of the reserves by the government was thought to be necessary because the aborigines were "ignorant/stupid" ( $y u$ 愚), and could be deceived by settlers if the government did not intervene. ${ }^{99}$ But overall, it was the first time that the government acted not as an adjudicator between settler-aborigine land disputes, but as an

\footnotetext{
${ }^{95} \mathrm{Ke}$, ibid, at 122, notes that the Han cheated the aborigines in the lease. Qinding pingding Taiwan jilüe [Imperially approved accounts of pacifying Taiwan] (TWWX 102), at 863, also mentions that the settlers' leader Wusha “leased and reclaimed aboriginal land" (zuken fandi 租鿶番地).

96 Wang Kaitai Fujian tongzhi Taiwanfu [Gazetteer of Fujian, Taiwan Prefecture, 1871] (TWWX 84), at 22. ${ }^{97} \mathrm{Ke}$, above $\mathrm{n} 94$, at 43.

98 Yao, above $\mathrm{n} 94$, at 75 . Yao recorded that the aborigines sought government protection in order to avoid being bullied by the plains aborigines, but in fact the perpetrators were probably mainly Han settlers.

${ }^{99}$ See the discussion among the officials in ibid, at 47-49.
} 
actor itself to take away aboriginal land, to distribute it to settlers and to manage the reserves for the aborigines.

\section{B Inner Shuishalian}

Chapter 2 discussed the debates about opening up Shuishalian for settlement. Before the central government finally decided to continue closing off inner Shuishalian, local officials had attempted to colonise the land.

As discussed in Chapter 2, the Fujian-Zhejiang Governor-General, Liu Yunke, investigated inner Shuishalian in 1746 (Daoguang 26). According to Liu's calculations, the six villages under consideration had 1,020 people, and occupied an area with about 12,000 jia of land that could be reclaimed. Liu reported that the aborigines were eager to surrender their land for the government to "manage". ${ }^{100}$ The concept of government "managing" aboriginal land had derived from the Gamalan approach.

What Liu did not allude to, and unbeknown to the central government, was that local officials had already made detailed plans to have the land reclaimed, and had started to implement them. The Aboriginal Affairs Sub-prefect for the Northern Circuit, Shi Mi, had arranged for "pilot reclamation" (shiken 試墾). This meant that the local government had raised money to reclaim the land as a pilot project before opening up the land for settler reclamation. ${ }^{101} \mathrm{~A}$ number of officials, including the Taiwan Circuit Intendant and the Taiwan Prefect, each undertook to provide funds for this venture. The Taiwan Regional Commander sent a troop of 200 soldiers to be stationed in the area. ${ }^{102}$ Probably this troop was there to intimidate the aborigines and to suppress any resistance, even though Shi reported that the aborigines "seeing that the government took control, were all very happy and at peace". 103

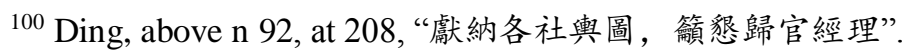

101 See Shi's report in ibid, at 252-258, in particular, at 252.

102 Ibid.

103 Ibid, “見官經理, 均極歡怰靜䍀”.
} 
Officials in total sponsored reclamation of about 2,000 jia of land as government estate. They also secured some wealthy Han settlers' undertaking to reclaim over 7,000 jia. ${ }^{104}$ The plan was that for each jia of land, the aborigines would receive one shi of grain every year, one-eighth of the usual large rent rate in Taiwan. Since the aboriginal population was small compared with the large area of land that they occupied, the total rent was deemed sufficient for the population at that time. ${ }^{105}$ However the plan essentially was a compulsory government action to deprive the aborigines of their land forever without proper compensation.

The local officials were forced to abandon their venture after the central government took the final decision not to open up the land. However, there was no question that if inner Shuishalian had been opened, the government would certainly have taken control of the land and provided the aborigines with only minimal compensation. Following the Gamalan approach, this was inconsistent with the pre-1800 policies. This approach continued in some post-1875 operations.

\section{After 1875}

After 1875, regulations were made to encourage settlement and land reclamation, but none specifically addressed aboriginal land rights. The extent of government recognition and protection of aboriginal land rights can only be gathered from various different sources. Some of the records contradict one another, but overall it appears that the Qing government continued to recognise aboriginal land rights to a certain extent, but the aborigines lost the right to decide whether to have their land opened up. The aborigines retained some rights to compensation, but the government followed the Gamalan approach in a number of cases.

\section{A Title}

When the Qing government launched the campaigns to "open the mountains and subjugate the aborigines", it had the clear objective to have the aboriginal territories settled by Chinese settlers. In 1874 (Tongzhi 13), the Imperial Commissioner to Taiwan, Shen

\footnotetext{
104 See the Taiwan Circuit Intendant's report at 233.

105 At 230 .
} 
Baozhen, reported to the Emperor that "behind the mountain ranges, apart from aboriginal villages, it is all vacant land" which must be filled with people and be reclaimed. ${ }^{106}$ The Qing had traditionally recognised aboriginal ownership over wasteland in Taiwan. Shen did not elaborate on whether this tradition was being repudiated now that the government was to promote land settlement. The question soon arose, and the answer became more or less clear only in the process of implementing land reclamation policies.

\section{The interim view}

A shift of principle emerged in 1875 (Guangxu 1) when the provincial government considered a county magistrate's proposal. The old assertion that the government owned all wasteland in Taiwan, denounced by Chen Bin, was now renewed.

This proposal came from the magistrate of the newly established Hengchun County, who asked for approval of his plans regarding aboriginal land within his jurisdiction. The magistrate stated: ${ }^{107}$

The forest land and fields have always been managed by the villages according to their boundaries. Now that [the aboriginal villages] have submitted, could it be allowed that they reclaim and farm the forest lands as usual; and those cultivated fields be exempted from tax? The county [government] will order them to specify the land boundaries and also draw pictures and compile ledgers for file. The village boundaries will remain, and [Han] villains (jiantu 奸徒) are forbidden from encroaching.... Those forest lands that the villages do not have the ability to reclaim and desire to lease to the settlers should be allowed to be leased and registered [with the government]...

This proposal clearly recognised aboriginal ownership over all unreclaimed land, as had long been the case. The proposal to allow aborigines to lease their land differed from the Gamalan approach where the government controlled and distributed aboriginal land, and was a reversion to the pre-1800 approach which respected aboriginal freedom of disposal. However the necessity to ask for an instruction reveals the magistrate's uncertainty and

\footnotetext{
106 Taiwan zouzhe, above ch 2 n 117, at 11.

${ }^{107}$ See in Sifa cankao, above n 61, vol 1A, at 41.
} 
points to a changed policy environment. Indeed, the Circuit Intendant, upon receiving the Governor's direction, answered that: ${ }^{108}$

... [Regarding] the cultivated land... [that] each be managed by the villages and exempted from tax is permissible. Those forest lands that the aborigines do not have the ability to farm, the county [magistrate] suggested that [they be] leased to the settlers. This may open the gate for later encroachment, and other plans should be made carefully. And all Taiwan is government land. Apart from those reserved for the village upkeep, it should be carefully planned as to how to draw boundaries and recruit reclaimers...

Here the Intendant clearly asserted that the unreclaimed land was government land. Since it was government land, the Intendant rejected the aborigines the right to lease it. The Intendant was ambiguous as to what plans should be made for the aborigines. It appears that the Intendant's response was only an interim answer, and later guidelines provided a clearer indication on defining aboriginal land and government land.

\section{The 1877 guidelines}

The Fujian Governor Ding Richang issued "21 guidelines for subjugating the aborigines and opening the mountains" in 1877 (Guangxu 3). ${ }^{109}$ Four of the guidelines related to land. Guideline 4 recognised that village lands were joined together, required clarification of village boundaries and forbade any village to encroach on neighbouring villages' land. ${ }^{110}$

\section{Guideline 5 stated that: ${ }^{11}$}

The government's hills that are near the sea and those lands that the aborigines are not able to reclaim can be reclaimed by settlers. Aside from these, the remaining hills, fields and trees that are attached to the [aboriginal] villages should each be managed

\footnotetext{
108 Ibid. Emphasis added.

109 “抚番开山善后章程 21 条”, in Fu Tai dang”an, above ch 2 n 119, at 7-9.

110 “各番社田地毘連，宜飭派委員酌選誠實通事带同番目分報各處，為之嚴定界址; 不准鄰社恃強 侵佔，亦不許該社冒佔他人土地，以杜爭端”。

111 “除近海官山及各番耕種力所不能及者聽民開墾外, 其餘附社山田樹木, 應令各歸各管, 不准地 方民人將該番所有占鴬已業”.
} 
by its village. Settlers are forbidden to occupy aboriginal property as their own property.

Guideline 16 set out the plan on educating and engaging the aborigines in agricultural work. Guideline 17 stated that "there is much vacant land in the front and at the back of the mountain ranges" and provided mechanisms for recruiting settlers from the mainland. ${ }^{112}$ Reading the regulations together, it is clear that the government encouraged aborigines to reclaim land, and settlers could only reclaim land that the aborigines were not able to reclaim. The reference to "government's hills that are near the sea" in Guideline 5 indicates that the government assumed ownership over land that was not actively controlled by the aborigines.

A decree issued by the Taiwan Circuit Intendant in 1878 (Guangxu 3) to implement Guidelines 4 and 5 made the above principle explicit. The Intendant's decree ordered local officials to survey the population and land boundaries of each village, to determine the amount of land that should be reserved for the aborigines and the amount that was beyond the villages' ability to reclaim, and to investigate land "that was distant from aboriginal villages and was wasteland without an owner". ${ }^{113}$ Three categories of land were distinguished here: aboriginal land to be reclaimed by aborigines, aboriginal land beyond the aborigines' ability to reclaim which would be reclaimed by settlers, and "wasteland without an owner" which implied government ownership.

It appears that the Guangxu government held the same view as that of Chen Bin. That is, land "actively controlled" by aborigines was aboriginal land, but land that was at a distance with less aboriginal control was seen as government's wasteland. Two things had changed, though. Firstly, the late Qing government was keen to have all land reclaimed, and was no longer willing to allow the aborigines to leave their land idle. Aborigines that surrendered to the Qing authorities were required to agree on seven conditions, one of which was

112 “前、後除近海官山及各番耕種力所不能及者聽民開墾外，其餘附社山田樹木，山各處曠土甚多， 應即舉設招墾局，即日由營務處選派委員前往汕頭、廈門、香港等處招工前來開墾”。

113 “離社較遠無主荒地”. Ibid, at 10 . 
reclamation of aboriginal land. ${ }^{114}$ Land that was recognised as aboriginal land but beyond the aborigines' ability to reclaim would have to be given up for settler reclamation. Secondly, Chen regarded all land as controlled by aborigines, but the late Qing government saw distant land as government wasteland. The standard of "control" appeared to have changed.

\section{Post-1885 approaches}

After 1885, the government continued to recognise aboriginal ownership over wasteland. Ding's successor Liu Mingchuan, in his memorial to the Emperor in 1885 (Guangxu 11), recognised that “non-acculturated aboriginal territories (dijie 地界), each belonged to a village" and recommended that "the military and settlers be not allowed to encroach". 115 Given that Liu vigorously promoted settlement and land reclamation, "non-acculturated aboriginal territories" probably referred only to areas around the aboriginal villages.

In some cases, the government required aborigines to explicitly relinquish their rights. Heads of surrendering aboriginal villages each gave an "undertaking of surrender" (toucheng ganjie 投誠甘結), and promised that “all forests, trees and land shall be open to harvest or reclamation by reclaimers, and [the village] dare not contest [against it in the future]". ${ }^{116}$ The government probably regarded this as surrender of the aborigines' title, even though the surrender might not have been voluntary.

A slightly different approach was adopted by the provincial government in 1888 (Guangxu 14). This policy recognised aboriginal rights over their forest and allowed them to cut down and sell the trees, but required the aboriginal villages to reclaim the land. What was not reclaimed within one year would be opened up for Han settlement. ${ }^{117}$ This was a method

\footnotetext{
114 Other conditions included shaving the heads, registering the population and no killing. See Taiwan zouzhe, above n 106, at 47.

115 Liu Zhuangsugong zouyi, above n 90, at 200, “生番地界，各歸各業，不許軍民侵占”.

116 “所有社内一切山林、樹木、土地，任憑耕人砍伐開墾，不敢爭競”. See 18 undertakings collected in Dan Xin dang'an, above n 62, vol 13, at 34-39. All the undertakings were given in February 1886 (Guangxu 12). It is not clear whether this was required of all villages, or at all times.

${ }^{117}$ Fu Tai dang'an, above n 109, at 145.
} 
suggested 160 years before by Lan Dingyuan in the early Yongzheng era, but it had not been adopted at that time.

Overall, just as it did before 1875, the government still recognised aboriginal rights over unreclaimed land, but now restricted this to land over which the aborigines had actual control of. Despite such recognition, the aborigines were forced to open up their land for reclamation.

\section{B Compensation}

No record has been found to suggest that the government had a system of taking land from the aborigines or regulated land transactions between settlers and aborigines. Scattered records and references show cases of aborigines receiving rents for land used by settlers.

In some cases, the aborigines retained the power to negotiate terms of use with the settlers, and the government intervened to protect aboriginal rights where necessary. For example, during the late Qing period, the government licensed settlers to cut camphor trees and make camphor products in the aboriginal territories. The government charged a tax for the production, but the aborigines retained property rights over their camphor forest, and received fees from Han settlers who manufactured camphor. ${ }^{118}$ Another example was that the Hengchun County made a set of rules regarding settler-aborigine relations, and one of the rules stipulated that settlers were to pay rents and fees to aborigines if they gathered wood and made charcoal in the mountains. ${ }^{119}$ This approach was similar to the pre-1800 approach, where the government let settlers negotiate use of land with aborigines and intervened only when conflicts arose.

\footnotetext{
118 Tavares "The Japanese Colonial State and the Dissolution of the Late Imperial Frontier Economy in Taiwan", above "Introduction" $\mathrm{n} 48$, in particular, at 370-372.

119 Tu Hengchun xianzhi, above ch 1 n 136, at 292. The extent of this arrangement is not clear. Inō Taiwan wenhua zhi, above "Introduction" n 32, vol 3, at 205, also records that settlers paid aborigines in goods for the use of aboriginal land.
} 
Other records also indicate that aboriginal villages received rent from land reclaimed by settlers, but under government arrangement. A memorial by Liu Mingchuan in 1887 (Guangxu 13) reads: ${ }^{120}$

I have checked that the seven villages in Daju have fewer than 1,000 aborigines, male and female included. The surrounding land extends over ten $l i$ and is fertile. Have settlers reclaim the land, and after two or three years, the rent is sufficient to provide grain rations for the seven villages. At the moment the government needs to find funds to feed [the aborigines].

The reference to grain ration (kouliang $\square$ 糧) suggests that the government assumed responsibility for the aborigines' livelihood. It is likely that the government took control of aboriginal land and in return took care of aboriginal livelihood, as was done in the Gamalan case. This was probably a widespread practice, as records elsewhere also show that the government provided aborigines with grain rations and clothing once they submitted to government authority. ${ }^{121}$

Also worth mentioning is a recommendation made by the Taiwan Circuit Intendant Liu Ao in 1883 (Guangxu 9). Liu discussed a piece of fertile land in the southern most point in Taiwan, which was suitable for reclamation. ${ }^{122}$ The document several times mentioned purchasing the land from the aborigines by the government, as an alternative to providing annual financial support to the aborigines. Liu's suggestion of purchase shows that the government did not entirely disregard the aborigines' property rights, and there was a practice of giving compensation for land taken. The reference to purchase as an alternative to annual provision to the aborigines confirms that the government saw the provision as a return for land taken.

The above examples show varying degrees of government intervention and different patterns of compensation. The prime focus was to have the wasteland settled and reclaimed,

\footnotetext{
${ }^{120}$ Liu Zhuangsugong zouyi, above n 90, at 222, “大埧七社, 番丁男女不及千人，其地週圍數十里，土 壤肥膄，以民墾之，二、三年後，即可以墾租給七社口糧，目前必由官籌資給食”。

${ }^{121}$ For example, see Fu Tai dang'an, above n 109, at 80.

${ }^{122}$ Liu Ao Xun Tai tuisilu [Reflections on being a Circuit Intendant in Taiwan] (TWWX 21), at 62-64.
} 
but on the basis that aboriginal ownership was generally recognised. It is likely that whether compensation was paid depended on whether the aborigines were strong enough to negotiate with the settlers or the government. Although the government still protected aboriginal rights over land that they cultivated or had the ability to reclaim, the Gamalan approach was preferred over the pre-1800 protection.

\section{The Effects of Legal Tradition}

Many parallels of protecting aboriginal land rights could be drawn from other frontiers in the empire. The policies to demarcate land boundaries between aboriginal land and settlers' land, and to order return of aboriginal land to the aborigines, were largely consistent with approaches adopted for other frontiers in the empire. In the first few decades of the Qing rule over China, when Manchuria was not strictly closed off, the land was divided into Han Chinese land and Manchu banner land. ${ }^{123}$ Regulations strictly forbade sale or lease of banner land to Han Chinese, and provided for return of banner land to the banners. ${ }^{124}$ Land in Mongolia was also protected from Han purchase and lease, and those who breached the law to lease, purchase or sell the land were to be punished. ${ }^{125}$ Similar policies were implemented in Yunnan to protect the Yunnan aborigines' land. ${ }^{126}$ Further, through to the early $19^{\text {th }}$ century, the government tried to prevent indigenous land being mortgaged or rented in Yunnan. ${ }^{127}$ It is apparent that there was a general pattern of protecting aboriginal land rights, shaped by Qing legal traditions.

\section{A Legal Tradition and Recognition of Aboriginal Land Rights}

The Chinese traditional concepts of the "King's" ownership over all land within the realm and "land grant" (shoutian 授田) in some respects were similar to the English doctrine of tenure, whose "two-fold fiction" assumed that the Crown originally owned all land, and

\footnotetext{
${ }^{123}$ Peng, above n 74, at 259.

${ }^{124}$ See Zhao and Chen, above n 5, at 58. Tang Zhongguo de kenzhi, above ch 2 n 144, at 173.

125 Tang, ibid.

126 See Giersch Asian Borderlands, above ch 2 n 134, at 121.

127 At 142-144.
} 
that all titles originate from the Crown. ${ }^{128}$ There were important differences, however. Chinese tradition focused on agriculture and the system classified land into two broad categories, agricultural land (tian 田) and other land ( $d i$ 地) which could be turned into agricultural land through reclamation. Unreclaimed wasteland was seen as "land without an owner". This means the system recognised that the "King's ownership" over wasteland was not a proprietary right as such, rather it was the power to make grants. ${ }^{129}$

The government's administrative power to make grants was not restricted by recognising aboriginal ownership over unreclaimed land. As this chapter demonstrates, the government could exercise its administrative power to require that the aborigines open up land for reclamation. Furthermore, the financial benefits that the government gained from land grants were not in the grants themselves, but in the annual land tax that grantees paid. Because the government did not have proprietary interests in wasteland, and did not take pecuniary gains from making grants, the government did not need to compete with the aborigines for ownership over unreclaimed land in Taiwan. Since recognising aboriginal land rights did not restrict the government's power to make grants and did not affect the government's financial interests, the Qing government readily recognised aboriginal ownership over wasteland in Taiwan. This was why the recognition was mostly consistent during the Qing period, even though government policies regarding land reclamation had shifted from restriction to promotion.

The recognition, however, was not universal in Taiwan. Some Qing officials had asserted that the government owned all land once the aborigines submitted, but these occasions were rare and they typically arose when the benevolence of the Emperor or the public power of the government to make grants was claimed. The concept of "land without an owner" was

\footnotetext{
${ }^{128}$ Ulla Secher "The Meaning of Radical Title: The Pre-Mabo Authorities Explained" (2005) 11 Australia Property Law Journal 179, at 243. For the development of the English land tenure, see Alfred W B Simpson A History of the Land Law (2ed, Clarendon Press, Oxford, 1986).

${ }^{129}$ In the recent decades the Common Law world has found that upon settlement, the Crown acquired only a radical title over the land, but not beneficial ownership. There are still debates about the exact meaning of radical title. Some jurists and scholars believe it to be equivalent to absolute ownership of land, subject to the burden of native title; others argue that radical title is a governmental power, as opposed to proprietary rights. See Secher, ibid, in particular, at 183, 185, 242 and 243. For the judicial pronouncement of radical title, see Mabo v Queensland (No 2) [1992] HCA 23, Brennan J, in particular, para 51; Ngati Apa v Attorney-General [2003] NZCA 117, Elias CJ, at paras 25-29.
} 
still at work in the government's view of wasteland in Taiwan. The government did not see an "owner" over those lands that the aborigines did not have clear control of, and regarded them as the government's wasteland.

It was therefore the legal tradition that allowed the recognition of aboriginal land in Taiwan, as well as limiting the recognition.

\section{B Legal Tradition and Protection}

The most important principles of Confucian legal thought were monarchism (junzhu zhuyi 君主主義), familism (jiazu zhuyi 家族主義), people-centredness (min benwei 民本位) and preference for good officials in maintaining good governance (zhifa yongxian 執法用 賢). ${ }^{130}$ As discussed in Chapter 2, monarchism and people-centredness in fact divided the constitutional actors in imperial China into two major parts, the monarch, who was the absolute authority, and the people, who formed the basis. Familism drew an analogy between governance of the empire and management of a family, emphasising the fatherlike figure of the monarch, who had authority over as well as responsibility to his subjects. Preference for good officials in maintaining good governance favoured "governing by men" and distrusted "governing by law". ${ }^{131}$ These principles, together with Qing consciousness of the fact that it was a minority ruler, shaped Qing protection of aboriginal land rights in Taiwan.

\section{The monarch and good imperial subjects}

Different from Western colonisation where the encounters were often one people against another, that is, the coloniser against the colonised, in Qing Taiwan, as in imperial China, the main relationship was the ruler over the masses. All peoples, settlers and aborigines alike, were all equal subjects of the Emperor. The objective of the government was to "make good imperial subjects out of the ... population". ${ }^{132}$ As this chapter demonstrates, ethnic relations in Taiwan were complex. To achieve a power balance and maintain social stability, the ruler suppressed those groups of people that were potential trouble-makers,

\footnotetext{
${ }^{130}$ Yang et al (eds) Zhonguo falü sixiangshi jianbian, above ch 2 n 26, at 24.

${ }^{131}$ Chen, above $\mathrm{n} 5$, at 61 .

132 Rowe, above n 44, at 507.
} 
and protected the groups that could be potential allies. In Qing Taiwan the trouble-makers tended to be the settlers. The Manchus' status as minority rulers likely also influenced the decision to favour the minority aborigines over the Han settlers.

As a result, in Taiwan the Qing Court sought to protect aborigines from settlers. The Court was fully aware of the importance of land, and protecting aboriginal land against Han settlement and encroachment was the most important part of protecting the aborigines. However, protection of aboriginal land rights was not an end itself, rather it was a means to achieve the end of power balance and social stability. This was the reason why the policy was inconsistent at times, allowing land reclamation provided it did not threaten social stability.

During the Qing's two centuries rule of Taiwan, the aborigines rarely rose against the government. In contrast, Han settlers often rebelled and the government continuously sought to guard itself against the settlers. This illustrates the government's relationships with the aborigines and settlers respectively, and also demonstrates the government's policy orientation and its effects.

\section{Paternalism}

Being the head of the big "family" and the carer of the people, the monarch and his officials had the responsibility for the wellbeing of the people. The Confucian and Mencian tradition called for a paternalistic approach towards the weaker party, that is, towards aborigines who faced settler aggression.

During the early Qing period, the emperors and many officials took the traditional paternalistic stance and saw the people as chizi (赤子 literally “naked child”, meaning a helpless baby needing protection). For example, Shi Lang's memorial to recommend annexation of Taiwan argued that "both the aborigines and settlers are [the Emperor's] children"; ${ }^{133}$ Zhuluo County magistrate, Ji Qiguang, pleaded that "now that Taiwan has entered the realm, the aborigines (tufan 土番) are [the Emperor's] children (chizi)". ${ }^{134}$ Chen

133 Shi “Gongchen Taiwan qiliu shu”, above ch 2 n 36, at 60, “土番人民均屬赤子”.

${ }^{134}$ Ming Qing Dang'an, above n 24, vol 9, at 79-80. 
Bin, the Circuit Intendant who argued for banning reclamation of aboriginal land, asked rhetorically, "Are they [the aborigines] alone not the children of the heavenly dynasty?". ${ }^{135}$ The Qianlong Emperor also claimed that "both settlers and aborigines are our children". ${ }^{136}$ Because of this attitude, the government felt an obligation to protect the aboriginal wellbeing, of which the main component was land. Therefore aboriginal land rights had to be protected. ${ }^{137}$

The limitation of this approach was that the land issue was seen as integral to aboriginal livelihood, but was not an issue of aboriginal land rights as such. Therefore, provided that aboriginal livelihood was secure, protection of aboriginal land need not be on the agenda. Believing that the aboriginal livelihood had been taken care of after the reserves were made, the government distributed the remaining land in Gamalan to settlers. Similarly, after 1875, the government took away aboriginal land and in return assumed the responsibility to provide food and clothing for the aborigines on an ongoing basis. Here the government was in the position of an authoritarian father, who had the authority to take away land and the obligation to provide for the "children". There was no parallel to modern law which requires a proper procedure to lawfully extinguish aboriginal title to land.

\section{Governing by men, not by law}

The Chinese tradition that "governing by men will work, but governing by law will not work" dates back 2,000 years to the Confucian philosopher Xunzi (313-238 BC). ${ }^{138}$ The philosophy behind this concept was that "laws cannot stand alone, precedents cannot apply themselves. With suitable persons, [laws and precedents] will be upheld; without suitable persons, [they] amount to nothing". ${ }^{139}$ Following this tradition, Chinese rulers believed that "the public enacting of law is not necessary in the ideal state, and ... government by law should always be kept secondary to government by moral precept and example". ${ }^{140}$

\footnotetext{
${ }^{135}$ See Chen's arguments for protection of aborigines in Chen, above $\mathrm{n} 35$, at 15-17.

${ }^{136}$ Gaozong shilu, above n 56, at 6.

${ }^{137}$ Shepherd, above $\mathrm{n} 36$, at 20 and 306, also notes that the "Confucian concern to preserve the livelihoods of subject peoples" and "the Mencian strand of Chinese statecraft" were part of the reasons the Qing protected aboriginal land rights.

138 “有治人, 无治法”, Xunzi, above ch 2 n 149, ch 12 “Jundao” [The way for a [good] monarch].

${ }^{139} \mathrm{Ibid}$, “法不能獨立, 類不能自行; 得其人則存, 失其人則亡”.

${ }^{140}$ Bodde and Morris Law in Imperial China, above ch 2 n 26, at 18.
} 
Following the Chinese legal tradition, law-making during the Qing Dynasty had two features - a system of administrative law and an emphasis on managing officials. ${ }^{141}$ The government focused more on cultivating good officials than making good laws. Laws were made to guide officials' actions, rather than to inform the people. This focus contributed largely to the inconsistencies of Qing land policies in Taiwan.

The reluctance to make law meant that there was no systematic law-making to address issues. Although during the Qing Dynasty, regulations proliferated, they were not coordinated and not always consistent. Individual regulations had loopholes, and collectively they were made in a piecemeal manner and could not address a problem or achieve the goal thoroughly. More often than not, laws were made to patch up a problem, when a situation had deteriorated. As the Yongzheng Emperor said, the government "should not change the law unless the change will bring ten-fold benefit, [and] should not change the custom unless the harm caused by the old custom is ten-fold". ${ }^{142}$ This was the reason why aboriginal land issues were not dealt with until a few decades after the annexation, and why the Qianlong government had repeatedly to clarify land boundaries and order return of land to aborigines after serious encroachment by settlers.

In addition, the emperors' supremacy above the law and the focus on good officials meant that the personal attributes and beliefs of the emperors and officials played an important role in protecting aboriginal land rights in Taiwan. As these attributes and beliefs varied, the policies and their implementation tended to be inconsistent. The Qing system in particular required the Emperor to play a part in every important decision, and had a strong characteristic of "personal rule". ${ }^{143}$ The Kangxi and Qianlong Emperors had strong views against land reclamation in Taiwan, and the protection was more vigorous during their reigns. When the Emperor and his central government were weak, as they were during $1800-1875$, the protection was weakened.

\footnotetext{
141 Zhang Qingchao fazhishi, above “Introduction” n 30, at 191-192.

142 “利不什，不變法; 害不什，不改制”. See Shizong shilu, above ch 2 n 46, at 20.

143 Fairbank and Teng “On the Types and Uses of Ch'ing Documents”, above ch 2 n 32, at 33-34.
} 
Therefore the belief that "governing by men" was better than "government by law" made policy-making and implementation flexible, but inconsistent at times.

Overall, the Qing protective stance towards aboriginal land rights was the result of Qing legal traditions, particularly: 1) the government's place in the land ownership system, and 2) the Confucian notion of good governance, which stressed the authority of the good monarch, benevolence towards the people and selection and management of good officials while intentionally neglecting law-making. Furthermore, the fact that formal law focused on administrative and criminal matters also meant that property matters were largely governed by Chinese customary practice. The next chapter discusses how this aspect of the legal tradition allowed Chinese land tenure to influence and change aboriginal land tenure in Taiwan. 


\section{Chapter 4}

\section{The Influence of Chinese Customary Land Tenure}

Although the Qing government endeavoured to protect the Taiwanese aborigines' land rights, by the late Qianlong reign the western plains had been fully reclaimed by Han settlers. A number of earlier studies have investigated the land rights over the western plains during the Qing Dynasty. In particular, Shepherd's study found that the aborigines held "large rent" rights over large areas in the western coast and enjoyed rental income till the Japanese period. ${ }^{1}$ In contrast, Ka's study argued that very little aboriginal rent existed at the beginning of the Japanese period, which meant that most aborigines had lost all rights over their land. ${ }^{2} \mathrm{Ka}$ has found three major methods of land loss by the aborigines - the irresponsible issue of land reclamation permits during the Kangxi reign which resulted in aboriginal land being reclaimed and registered by Han settlers; the Yongzheng government's willingness to permit land registration by Han settlers over land leased by aborigines to settlers; and the Yongzheng and early Qianlong governments' encouragement of registration of aboriginal land by aborigines, which enabled aborigines to sell their land. ${ }^{3}$ Ka further argues that a Taiwan Circuit Intendant's decree in 1688 (Qianlong 33) to exempt aboriginal land from tax (hence from registration) closed the loophole for land loss by the aborigines. ${ }^{4} \mathrm{Ka}$ 's view essentially attributes land loss by aborigines to the period before the mid-Qianlong reign and to government action, and equates land registration with land ownership.

The detailed statistics which Ka has presented were mostly from Japanese investigations in 1905, and the rest were from the late Qing period. ${ }^{5}$ By then the aborigines still owned $10.55 \%$ of large rent income out of the total "large rent" over land in the western plains, and $19.82 \%$ out of the total "large rent" west of the central mountain ranges (including areas bordering aboriginal boundaries). ${ }^{6}$ Considering that Han settlement had been

\footnotetext{
${ }^{1}$ Shepherd Statecarft and Political Economy on the Taiwan Frontier, above "Introduction" n 35, at 8-9.

${ }^{2}$ Ka Fantoujia, above "Introduction" n 39, ch 4 and 5, and at 316-332.

${ }^{3} \mathrm{Ch} 4$ and 5, and at 357.

${ }^{4}$ At 220.

${ }^{5}$ At 318 and 323, Table 11.2.

${ }^{6}$ At 324, Table 11.3.
} 
expanding for over 200 years by the time the statistics were collected, these percentages, although relatively small, suggest that the government's protection policies were not completely ineffective. It should be noted, however, rental income did not necessarily indicate land ownership in Qing Taiwan. As will be demonstrated in this chapter, settlers and aborigines had made complex and dynamic private arrangements regarding land. These private arrangements were often used to evade government regulations purporting to protect aboriginal land rights. As such, land loss by the aborigines was a continuing occurrence, largely unaffected by registration regulations.

It is the core argument of this thesis that aboriginal land holdings in Taiwan during the Qing era were reduced not by the state but by means of commercial interaction with Han settlers. In order to understand how this worked out, it is necessary to explain how the Chinese land tenure system worked, generally and in Taiwan, and the precise ways in which this interacted with aboriginal lands. This chapter therefore evaluates the relationship between land registration and land ownership in Qing Taiwan, and examines the consequence of private land transactions for the aborigines. The chapter pays close attention to Chinese customary land practice, and reinterprets some land deeds and analyses the legal nature of the major land transaction forms in Taiwan, namely, $z u$ (租 “lease"), $p u$ (贌 similar to $z u$ but with a different origin), dian (典 pledge) and sale (mai 賣). The land deeds relied upon are mainly from a collection known as Qingdai Taiwan Dazu Diaochashu (Collection of large rent documents in Qing Taiwan), ${ }^{7}$ and supplemented by deeds from Sinkang Manuscripts. ${ }^{8}$ There are other series of land deed collections, ${ }^{9}$ but Dazu Diaochashu represents the most comprehensive collection of land deeds, and Sinkang Manuscripts collects the earliest available deeds. As this chapter examines the general trend rather than land transactions in a certain locality or with a certain aboriginal group, these two collections provide the best examples.

\footnotetext{
${ }^{7}$ Dazu diaocha, above ch 3 n 22.

${ }^{8}$ Paul Jen-kuei Li Xingang wenshu yanjiu (Studies of Sinkang Manuscripts) (Academia Sinica, Taipei, 2010).

${ }^{9}$ For example, Liu Ze-min Pingpu baishe guwenshu [Historic documents of a hundred plains aboriginal villages] (Taiwan Historica, Nantou, 2002); Liu Ze-min Dajia dongxishe guwenshu [Historic documents concerning the Dajia East and Dajia West villages] (Taiwan Historica, Nantou, 2003); and other collections.
} 
Part I examines the customary practice of $z u$. It traces the emergence of dazu (大租 "large rent") and analyses the rights and legal status of large rent holders, who were the registered yezhu (業主 literally “proprietary owner") on the government's land tax register. This part argues that "lease" by large rent in effect became a re-grant of land to the lessee of "large rent", and registered yezhu were not necessarily proprietary owners of land. In other words, Chinese customary land practice, not the government land register, determined land ownership.

Part II traverses the evolution of aboriginal land transaction forms. Continuing from the argument of Part I, this part argues that the Chinese customary land transactions and voluntary privatisation of land by the aborigines caused large scale land loss by aborigines and major damage to aboriginal land tenure. Registration of aboriginal land by settlers or by aborigines did not affect the legal consequence of private land transactions.

Part III examines the lack of material distinction between $p u$ and pledge, and pledge and sale. Chinese customary practice exhibited great flexibility but lacked clarity. As such the customary practice often evaded government regulations that tried to protect aboriginal land. The government made efforts to restrict or prohibit land transactions between settlers and aborigines, but there was no systematic property law regulation to address the lack of precision or lack of clear distinction among the terms. Consequently, in general, government actions were not able to control Chinese customary practices.

Part IV concludes that the slow penetration of Chinese customary practice, rather than government action, changed Taiwan's aboriginal land tenure. However, the government's unwillingness to interfere with land practices, and the manner of interference when it did interfere, contributed to the problem. 


\section{Zu: "Large Rent" and "Small Rent"}

The ordinary meaning of $z u$ is rent, hire, lease or let. ${ }^{10}$ Therefore, as with the European and Common Law concept of a lease, it indicates a temporary parting with the use of property for monetary or material return. Like reversion in the English Common Law, the lessor retained the property right for the duration of the lease, and regained use and control of the property at the end of the lease term. However not all $z u$ in imperial China were straightforward leases as the ordinary meaning suggests. The customary practice in Qing Taiwan, which mirrored that of mainland China, was a lot more complicated than the English terms lease or rent indicate, because of the "large rent" system (dazu 大租). "Large rent" stood in contrast to "small rent" (xiaozu 小租), and they were related to the "one field, two [levels of] owners" (yitian liangzhu一田雨主) system. This system emerged in the Song Dynasty (960-1279AD) and was widely practised in mainland China. ${ }^{11}$ The emergence of the system was related to land reclamation and subsequent separation of rights over land. ${ }^{12}$ Given suitable condition, the Chinese settlers were able to replicate the system in Taiwan.

\section{A Land Reclamation Permits}

As discussed in Chapter 3, permits were needed for land reclamation in Qing Taiwan. Anyone could apply to the government for a reclamation permit, but in reality only a few people had the connection or knowledge to make applications. ${ }^{13}$ An application for a permit

\footnotetext{
${ }^{10}$ Martin H Manser (ed) Concise English-Chinese Chinese-English Dictionary (2ed, Oxford University Press, Oxford, 1999), at 602.

${ }^{11}$ Terada Hiroaki "Tianmian tiandi guanli de falü xing: yi gainianxing de fenxi weizhu" [The legal nature of the customary practice of top-soil and sub-soil rights: a conceptual analysis] in Yang Yifan and Terada Hiroaki (eds) Zhongguo fazhishi kaozheng [Research on Chinese legal history Volume 4 Part 3] (Zhongguo shehui kexueyuan, Beijing, 2003) 344-422 discusses the system in imperial China, and examples given were from various provinces in China. Also see Tai Yen-hui "Qingdai Taiwan zhi daxiaozu ye" [The large rent and small rent rights in Qing Taiwan] (1963) 4 Taipei Wen Hsien 1, at 2.

12 Tai, ibid, at 2-4.

${ }^{13} \mathrm{Li}$ Wen-liang Qingdai nan Taiwan de yiken yu Kejia shehui (1680-1790) [Land reclamation and Hakka communities in southern Taiwan during the Qing Dynasty] (NTU Press, Taipei, 2011), at 49.
} 
made to the Taiwan local government in the second year after the annexation (1685) reads: ${ }^{14}$

Applicant Shen Shaohong [is filing this petition] for the matter of a notice of land reclamation. In the north circuit there is a parcel of wasteland in Luyecao, [which] was an old military farm ... during the Zheng period. It is a reasonably large area, and no one has applied for reclamation before. [I] petition your honour to approve me to appoint Li Ying as manager and to recruit tenants to reclaim [the land], and [I] will start paying land tax after the period of three years. [I] further petition your honour to notify the Taiwan Circuit Intendant that within the four boundaries listed [in the permit], Li Ying is authorised to go to Luyecao and build a house there, recruit tenants to reclaim the land as my inheritable property for ever [yongwei shiye 永為世業]. Thus is my humble request.

[Boundaries in four directions to hills or river respectively]

[Date]

Below the application was an annotation of the local official:

Wasteland reclamation. By order from the superior, it has been approved for a permit to be issued with speed, so that [the applicant] can recruit tenants and make arrangements as soon as possible. Once the land is fully reclaimed, [it] should be registered for tax according to law.

Some aspects of this application need to be emphasised. It only indicated that the land was a large area, but did not mention the number of jia. The reason is that land was surveyed only after it had been reclaimed. The document referred to a manager and tenants, which suggests that the applicant was a land investor who did not reclaim the land or manage the tenants personally, and this fact was known to the officials. The application also promised to register the land for tax after the reclamation was completed, this being the major concern of the government.

\footnotetext{
${ }^{14}$ Dazu diaocha, above n 7, at 1. Appended as Appendix 1(1) to this thesis.
} 


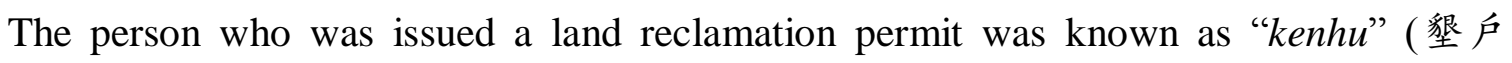
reclaimer). The format of permits might vary, but a permit usually listed the land under application, the boundaries and the name of the kenhu, and stipulated that once the land was fully reclaimed, it had to be registered for taxation within the required time. The earliest land reclamation permit available on record, issued in 1708, reads: ${ }^{15}$

...according to kenhu Zhan Sheng's application, there is a parcel of wasteland measuring over $10 \mathrm{jia}$ at [location and boundaries]. According to the investigation of the Interpreter (tongshi 通事) Xie Zhang and others, there is no violation [to aboriginal land boundaries], ${ }^{16}$ and a permit should be issued. Therefore, giving kenhu Zhan Sheng permission to reclaim the land as applied and pay land tax, this permit is issued.

[Date]

Permits conferred only rights to reclaim land and did not confer title over land as such, but they were the prerequisite for land title. Once the land was developed to be suitable for cultivation, the land was surveyed to ascertain the number of jia and then registered for taxation. The registered tax payer was called "yezhu", the owner of ye. As will be analysed below, the owner of ye does not necessarily mean the owner of land.

\section{B Land Reclamation Deeds and "Large Rent"}

As shown in the above two land permit documents, a land reclamation permit could grant large areas of land to the applicant. The 1685 application covered a "reasonably broad area", the boundaries being rivers and hills. In some cases, a land reclamation permit could relate to substantial areas covering several hundred jia of land. ${ }^{17}$ Because many grants were quite large, and also because of the Chinese way of intensive farming, permit holders usually

\footnotetext{
${ }^{15}$ At 1-2. Appended as Appendix 1(2) to this thesis.

${ }^{16}$ Tongshi means "to liaise", "to intermediate". The common translation for tongshi is interpreter, because to be a tongshi one had to be able to speak both Han and aboriginal languages. Interpreters were chosen by aboriginal villages or appointed by the government to assist with village affairs and official matters. An interpreter usually had the biggest power in the village affairs. After Wang Minzheng's decree in 1704, it was a usual process that before issuing permits government officials would investigate whether the land concerned encroached on aboriginal land.

${ }^{17}$ Taiwan Prefect Shen Qiyuan "Zhi Tai siyi" [A private discussion on administering Taiwan] in Taiwan lifan guwenshu [Historic documents concerning Taiwan aboriginal affairs] (Chengwen, Taipei, 1983), at 69.
} 
subdivided the land for others to reclaim. This was done by a separate document, a “reclamation deed" (geiken pi 給墾批). These deeds were private agreements, and did not involve the government. The actual reclaimers were called "tenants" (dian 佃), and the annual payment that they had to pay the permit holders was called "rent" ( $z u$ 租). This type of arrangement was common in Qing Taiwan, and by the late Kangxi reign it was estimated that about $60-70 \%$ of land granted to permit holders was given to "tenants" to reclaim. ${ }^{18}$

Three deeds during the Yongzheng reign illustrate the gradual evolution of reclamation arrangements and the increasing rights of the tenants. The first deed was made in $1725:{ }^{19}$

I, Ya, have an estate in Mamingshan. Out of [this estate I] give a piece of wet land, measuring 1.2 jia, to tenant Cai Zanheng to reclaim. For the first and second years [the rent is] $15 \%$ [of the harvest], and [from] the third year, following precedents, [the rent] is eight shi per jia of winnowed and clean good grain. [The tenant shall] transport the grain to the granary. [The rent] shall not be short [of the stipulated amount]. This deed is made and given as a proof.

Yezhu Chen Ya

[Date]

The second deed was made in $1729:{ }^{20}$

The person who makes this deed of reclamation, yezhu Jian Linfang, has a piece of land that he $p u$ from the Southern Dadu aborigines. Now Lin Shengheng is willing to cultivate it with his own draft oxen and seeds. It is agreed that for each jia of land [Lin] will pay litouyin (犁頭銀 “plough-head money”) 50 taels of silver as a contribution to build canals. The silver is paid on this day. The land is surveyed [by the parties] and it measures $10 \mathrm{jia}$. The boundaries are clear. It is agreed that for each jia of land the tenant will pay five shi of grain in the first year, eight shi in the second year, and afterwards eight shi per jia as a perpetual precedent. After the harvest, the grain must

\footnotetext{
18 Zhou Zhuluo xianzhi, above ch 1 n 124, at 95.

${ }^{19}$ Collected in Dazu diaocha, above n 7, at 59. Appended as Appendix 1(3).

${ }^{20}$ At 59-60. Appended as Appendix 1(4).
} 
be blown clean and transported to Luzaigang. [The tenant] dare not pay [the rent] short or late so as to affect tax payment. If the rent is in arrears, yezhu is free to evict the tenant and recruit other tenants. If in the future the county magistrate surveys the land, the tenant should pay rents according to the actual number of $j i a$ and shall not dispute. If the tenant is going home [in mainland China], after consulting yezhu, he is free to assign [the leasehold], and yezhu cannot share [the price of] the labour and capital [that the tenant invested]....

The third deed was made in $1732:^{21}$

The person recruiting tenants, $y e h u^{22} \mathrm{Li}$ Chaorong, has bought a parcel of wasteland (qingpu 青埔) at Datu, ${ }^{23}$ [specific location and boundaries]. Now [yezhu] recruited [tenants' names] to take up the lease and reclaim [the land]. [The tenants] offer puyin (埔銀“"soil money”) 65 taels of silver, are willing to bring their own draft oxen and farm tools and build irrigation canals, and will reclaim and cultivate [the land] as their own perpetual property [yongwei jiye 永爲已業]. The annual rent is $15 \%$ of the total produce, following local precedents. Once the land is fully reclaimed as paddy land... the rent is eight shi [of grain] per jia. [The tenants will] transport [the grain] to the harbour for payment of rent. [The agreement is reached by] both parties' free will, [and neither party] dares to repudiate in the future, or to request for increase or decrease of rent. [The tenants] will pay the rent in full and on time. If there are any arrears or insufficient payment, [the yezhu] will resort to the officials to enforce the payment. Lest oral agreements do not form evidence, a tenancy deed is given.

The puyin is received this day and acknowledged.

[Date]

Tenancy deed given by Li Chaorong

${ }^{21}$ At 60-61. Appended as Appendix 1(5).

${ }^{22}$ Yezhu (the owner of ye) was also called yehu 業户 (the person who has ye).

${ }^{23}$ Qingpu 青埔 (green land), huangpu 荒埔 (waste land) and caodi (草地 grassland) all referred to unreclaimed land, wasteland. It was rare that a yezhu would sell the title rather than recruiting tenants. Therefore the purchase referred to here was likely to be from aborigines. 
The three deeds above have been quoted in full in order to document the evolving practice with regards to the kinds of conveyances. The first deed shows that at least by 1725 (Yongzheng 3), the annual rent rate of eight shi of grain per jia of land had become a commonly adopted precedent. No term of the "lease" or consequence of default was mentioned. In the early stage of land reclamation activities, the necessity of defining property rights probably was not apparent.

The second deed specified that the rate of eight $s h i$ was to be perpetual, but in cases of rent arrears, the yezhu had the right to evict the tenants and lease the land to other people (qigeng huandian 起耕換佃). However, the tenant had the freedom to assign the "leasehold" to someone else after consulting with, or in reality, notifying, the yezhu. The anticipated sale of leasehold by the tenants was in the form of recovering labour and capital investments, and the deed specified that the yezhu could not claim a share of the sale price. Thus the tenant gained independent property rights, but the yezhu retained rights to evict the tenants.

In the third deed, not only the rent was fixed for perpetuity, the contract itself was perpetual, and the tenant was given perpetual rights over the land. In the case of rent arrears, the yezhu could resort to the government for enforcement, but did not have the right of eviction. Thus the yezhu's rights to replace tenants were eliminated, while the tenants' permanent rights over the land were guaranteed.

These deeds show the increasing rights of tenants - at first they appeared to be tenants, but eventually they had rights of "perpetual property". In line with the increasing rights of the "tenants", there were subtle changes to the initial lump sum payments. In the second deed quoted above the initial payment, litou yin, was said to be a contribution for irrigation work. $^{24}$ This implies that the parties had agreed that the yezhu had the obligation to build the irrigation system. In the third deed, no reason for the initial lump sum payment was mentioned, and it was the tenants who were responsible for building the irrigation systems. This suggests that an initial payment became an accepted norm, and became detached from a specific investment on the land. The payment was called puyin, or more commonly, pudi

\footnotetext{
${ }^{24}$ Litou means "head of a plough", which probably was related to reclamation of land.
} 
yin 埔底銀. Pudi literally means "bottom of unreclaimed land". Thus it appeared that the initial payment changed from a contribution to infrastructure work to in effect purchasing price for rights over the sub-soil. ${ }^{25}$ Essentially the tenants were purchasing an estate from the yezhu.

The deeds were in fact a consolidation of Chinese customary practice. At least over a decade before the deeds quoted above, tenants acquired considerable rights over land that they were given to reclaim. A Zhuluo County magistrate of the late Kangxi period complained that yezhu were not free to replace tenants, which would result in tenants becoming the property owner (jiudian cheng yezhu 久佃成業主) in the future. ${ }^{26}$ Moreover, the tenants enjoyed rights over the "sub-soil" (tiandi 田底) which were bought and sold independently from yezhu's rights over “top soil”" (tianmian 田面). ${ }^{27}$ The distinction of subsoil and top-soil was artificial, as they did not really relate to the sub-soil or surface. In reality they referred to the different rights enjoyed by reclaiming tenants and yezhu.

The development of the practice from simple leases to de facto sales was not uniform in time and space. Whether reclaiming tenants acquired independent sub-soil rights or not would have been influenced by local customs, as well as the intention and negotiating power of the parties. However as time went on, the split-ownership system matured and became wide spread. ${ }^{28}$ In most cases the yezhu's only responsibility was to acquire a land reclamation permit, register the land once the reclamation completed, and pay land tax. Yezhu became a kind of property investor who obtained their profits from the difference between "rental" income and tax obligations. ${ }^{29}$

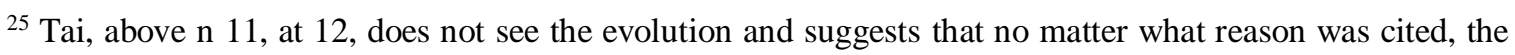
money was a price for the right of reclamation. This seems unlikely, because if a specific reason was mentioned, the relevant party would have to fulfil the obligation.

${ }^{26}$ Zhou, above n 18 , at 95.

${ }^{27}$ Ibid.

${ }^{28}$ Tai, above $\mathrm{n} 11$, at 23 , notes that the complete split of ownership occurred during the Jiaqing reign.

${ }^{29}$ Depending on the category of land, land tax varied from 1.71 shi to 2.74 shi per jia, while large rent rates were 4 shi and 8 shi per jia for dry land and wetland respectively. See Lian Taiwan tongshi, above ch $1 \mathrm{n}$ 92, at 191-192 for lists for tax rates in Qing Taiwan.
} 
Reclaiming tenants often reclaimed more land than they could cultivate themselves. In many instances they further subdivided the land and leased the pieces to third parties who were the actual cultivators. The sublease usually was a short term or periodic tenancy. Since there were two levels of "lease/tenancy", yezhu was hence called "large rent holder" (dazu hu 大租户), ${ }^{30}$ who received the customary eight shi per jia from the reclaiming tenants. The reclaiming tenants, because they sub-let in their turn, were called "small rent holder” (xiaozu $h u$ 小租户). Over the years a three-tier tenurial system developed (see Chart 16).

In summary, at its maturity, lease in large rent gave small rent holders independent proprietary rights called "sub-soil" rights, and large rent holders enjoyed "top-soil" rights. Each had an income attached to it and could be alienated independently from the other. Small rent rates were a few times higher than large rents, an indication that sub-soil rights were more valuable than top-soil rights. ${ }^{31}$ The system was complex, and was the product of dynamic development.

\section{Yezhu's Rights and Nature of Large Rent}

After land reclamation was completed, permit holders were registered on the government tax book as yezhu, which means the owner of ye. Theoretically, only when land was fully reclaimed did it become ye. ${ }^{32}$ In a modern context, the word ye has a range of different meanings, with connotations of industry, occupation and property. ${ }^{33}$ In the context of land rights during the Qing Dynasty, commentators have pointed out that ye means "land in which labour and capital have been invested", "[business] management", and "the object of control and management". ${ }^{34}$ In this sense, yezhu means the person who invested in the

\footnotetext{
30 The first reference to the term "large rent" appeared in a notice issued by the Zhanghua county magistrate in 1732 (Yongzheng 10), which required tenants to pay large rent to the yehu. See Tai, above n 11, at 22. See the notice in Dazu diaocha, above $\mathrm{n} 7$, at 8.

31 A deed in Dazu diaocha, ibid, at 154, shows that for the same piece of land, the large rent was 12 shi, and the small rent was 63 shi. Also see Chen Qingdai Taiwan tuzhu diquan, above "Introduction" n 43, at 153.

${ }^{32}$ Azuma Yoshio “Qingdai Taiwan zhi tudi suoyou xingtai” [Land owning system in Qing Taiwan] in Taiwan jingjishi chuji [A first collection of the economic history of Taiwan] (Taiwan yanjiu congkan 25, Taiwan yinhang, Taipei, 1954) 86, at 95.

${ }^{33}$ Manser (ed), above n 10, at 519.

${ }^{34}$ Azuma, above n 32, at 95; Wang Taiwan falüshi gailun, above ch 3 n 8, at 79; Tai, above n 11, at 20.
} 
land and had "real control", or cultivation and management rights, over such land or business operation. ${ }^{35}$

This, however, is misleading. Large rent holders did not work the land themselves. They did not invest labour, and as time went on, tended not to invest capital either. Further, large rent holders did not have control over land, and could not raise the rent or terminate the lease. ${ }^{36}$ Large rent was fixed in perpetuity, and the rates were largely consistent across Taiwan, unless in exceptional circumstances such as where the land quality was poor. ${ }^{37}$

In contrast, small rent holders had substantial rights over land. They could alienate the leasehold without obtaining large rent owners' consent, although the sale deed usually set out the large rent obligation, so that large rent owners continued to receive their due. As shown in the 1732 deed, the small rent holder would not lose the leasehold even in cases of default. A later deed recorded that if the yezhu seized the land in cases of default, the yezhu had to return the land once the rent was recovered. ${ }^{38}$ Small rent holders could use the land as they pleased without being interfered with by the yezhu. At the late stages of the system, the extent of small rent holders' rights was such that they could lease agricultural land for building a house, ${ }^{39}$ or even damage the land so that it was no longer suitable for production. ${ }^{40}$ Therefore the rights of small rent holders over land were not restricted in any way, as long as they continued paying rent to the yezhu as head lessee.

Thus, small rent holders had independent and unlimited proprietary rights over land. In fact, their rights were "the biggest rights over land". ${ }^{41}$ The sale of small rent holders' rights was called "sale of farmland" (maitian 䝴田), an expression that emerged as early as 1735

\footnotetext{
${ }^{35}$ Azuma, ibid. Also see Taiwan sifa, above ch 2 n 132, vol 1, at 52.

${ }^{36}$ Tai, above $\mathrm{n} 11$, at 26-27. Terada, above $\mathrm{n} 11$, at 344-422 analyses the arrangements and real meanings of the two-tier ownership system in imperial China.

${ }^{37}$ The rent was $15 \%$ of the total harvest where a percentage was adopted. If it was by fixed quota, it was usually eight shi per jia. This is a well recognised fact.

${ }^{38}$ See the deed of 1893 (Guangxu 19) in Dazu diaocha, above n 7, 128-129.

${ }^{39}$ See Taiwan Guanxi Yanjiuhui Taiwan guanxi jishi [Records of customs of Taiwan] vol 1B (Chinese translation, Taiwansheng wenxian weiyuanhui, Taizhong, 1984), at 192.

${ }^{40}$ In this case the small rent holders would be obliged to buy out the large rent rights. See ibid.

${ }^{41}$ Taiwan sifa, above n 35, at 186. But Taiwan sifa denies private land ownership in imperial China, and hence did not recognise any rights as ownership.
} 
(Yongzheng 13). ${ }^{42}$ Some Qing officials, who were more clear-minded, also recognised that when large rent holders gave land for reclamation, it was no different from "selling the property” (maiye 賣業). ${ }^{43}$ Eventually, small rent holders were referred to as “field owners" (tianzhu 田主), to distinguish them from the yezhu. ${ }^{44}$ In contrast to "sale of farmland", the sale of large rent rights was called "sale of rent [collection rights]" (maizu 賣租). ${ }^{45}$ It has been argued, and in my opinion correctly, that large rent holders' rights were merely debt collection rights, or a charge on the small rent rights. ${ }^{46}$

Hence large rent rights also went through an evolutionary process, and large rent holders lost their control over land over time. As shown in Chart 16, the government granted land titles to yezhu. In relation to the government, yezhu had independent rights which were alienable and perpetual. At this stage, yezhu had ownership over the land. Yezhu were free to reclaim and cultivate lands themselves, or to grant them to reclamation tenants as the tenants' perpetual property. When yezhu granted perpetual rights to reclaiming tenants, they passed property rights to reclamation tenants, and the split-ownership system was complete. The yezhu, who was now the large rent holder, no longer enjoyed real control or management rights over land, but only retained rights to collect rents. The initial lump sum payment was in effect the purchase price for property. The annual payment, although in the name of rent, was almost like the service or fee that tenants paid their lords in feudal grants in the English system, although in Taiwan the relationship was contractual rather than feudal, and the parties were on equal footing, at least legally.

It should be noted that split-ownership did not occur in all cases, and could have variations. For example, if a yezhu reclaimed and cultivated the land himself, no lease relationship existed. The yezhu could also reclaim the land himself but lease it for periodic tenancy, and

\footnotetext{
${ }^{42}$ See deeds of sale or mortgage of land in Dazu diaocha, above n 7, at 185-266. See the 1735 sale of land deed at 187.

${ }^{43}$ See a memorial by the Grand Councillor A'gui in Tai'an jiaji, above ch $1 \mathrm{n}$ 135, at 183, “業户前已得交 犁頭錢，即與賣業無異”。

${ }^{44}$ For example, see Chen Danshui tingzhi, above ch 2 n 115, at 88. Also see two land reclamation deeds of 1872 (Tongzhi 11) in Dazu diaocha, above n 7, at 162-164.

${ }^{45}$ See deeds of sale or mortgage of large rent rights in Dazu diaocha, ibid, 286-316.

${ }^{46}$ Taiwan sifa, above n 35, at 176-186; Tai, above n 11, at 26.
} 
theoretically enjoy "large rent" and "small rent" in one person. In the above two cases the ownership was not split, but belonged completely to the yezhu. If a reclamation tenant reclaimed and cultivated the land himself, there was no sub-lease and hence no small rent. However the prevalent practice in Taiwan was the three-tier lease system depicted in Chart 16.

In summary, at the maturity of the split-ownership system, in legal terms a large rent holder's reclamation deed was not a lease, but a grant of land. Although the annual fee was called "rent" ( $z u$ 租), lease in large rent in effect became permanent alienation of land. A large rent holder was none other than the person who was granted the right to reclaim land, and who in turn granted that right to small rent holders. Large rent holders were a special class who used their connections or knowledge to apply for land permits and who lived on rental income which was in reality a fixed annual fee. Small rent holders were the real $k e n h u$ and the real land owner. The next section further explores the legal status of yezhu and the legal effects of land registration.

Chart 16 Three-tier Land Rights System

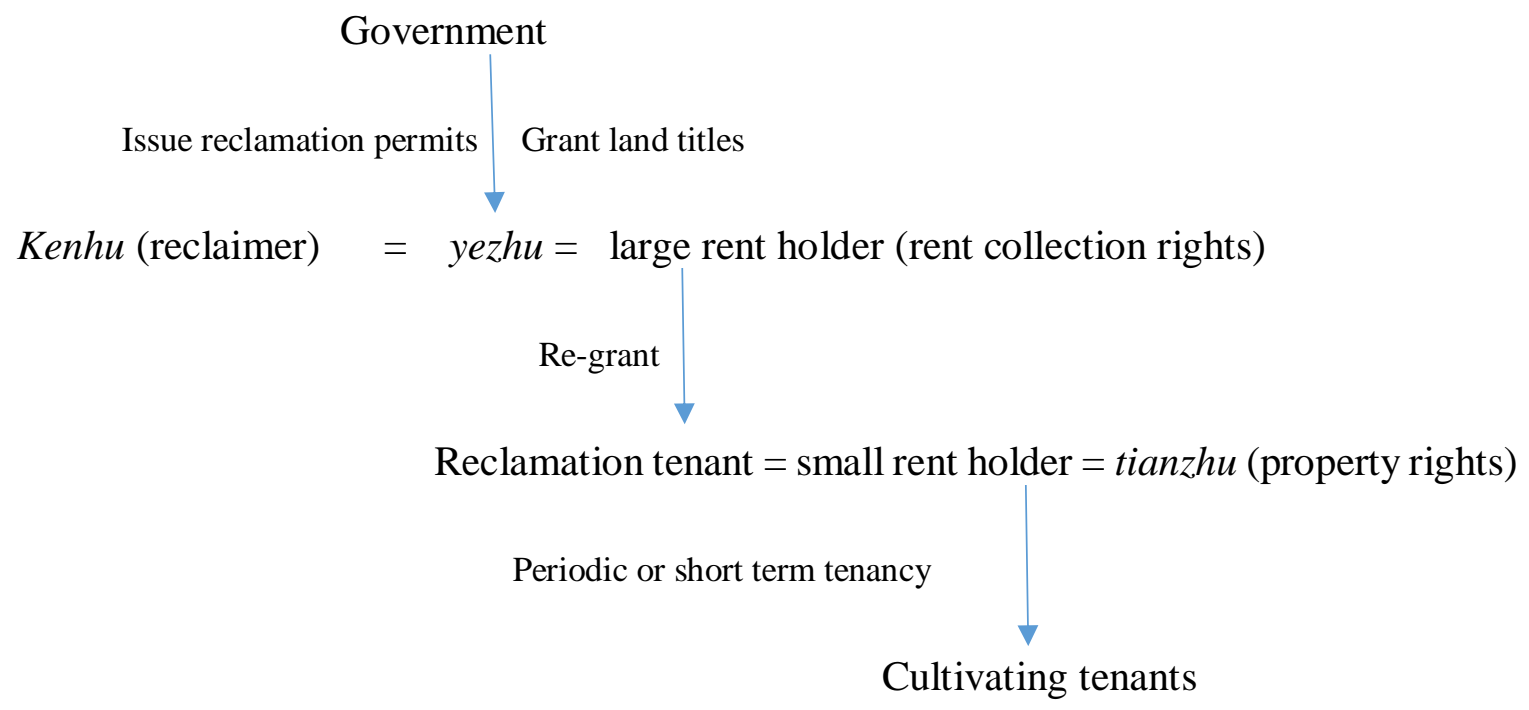




\section{$D$ Yezhu's Legal Status}

In Chinese customary practice, yezhu lost proprietary rights when they re-granted land to reclaimers. In the state law, being registered as yezhu did not necessarily mean ownership either.

It had always been the Chinese tradition that land title holders should pay tax. Before the Eastern Jin period (317-420AD), tax was levied according to the actual produce of the land rather than on the land itself. But after the Eastern Jin, tax was levied according to the area of land regardless of how much it produced ${ }^{47}$ In Qing Taiwan, lands were classified into different categories according to their quality and productivity, and each category attracted a different tax rate.

As discussed in Chapter 3, the government kept land registers for taxation and other administrative purposes. The "fish scale register" was the main land register. The "yellow register" and the transaction register supplemented the fish scale register through recording household land holding and land transactions respectively.

The land registers could serve as prima facie proof of title, but they were not the final proof of title. A registered yezhu might be the real owner of the land, but there were situations where the yezhu was not the real owner. For example, in Fujian province, a practice of “undertaking for tax grain” (baoliang 包糧) was prevalent. Land owners did not want to deal with the government on tax issues, and the undertakers got on the register specifically for the purpose of making tax payments on behalf of the land owners. The undertakers' only rights and obligations were to receive a certain amount of grain and pay a part of it as tax. ${ }^{48}$ The undertakers made a profit from being on the register, while the land owners were spared tax problems. For all parties concerned, the undertakers were not the real owners of land. In the case of Taiwan, recipients of land permits registered as yezhu when reclamation was completed. There were even cases where some people applied for reclamation permits over land that had been reclaimed by other people. In such cases the people who reclaimed

\footnotetext{
${ }^{47}$ Zhao and Chen Zhongguo tudi zhidushi, above ch 3 n 5, at 180.

48 Tai, above n 11, at 3-4.
} 
the land ended up becoming the permit holders' tenants and had to pay "large rent" to the permit holders. ${ }^{49}$ In this regard, the yezhu was not the real owner of ye, but the person registered on the land tax register. Their only right was to receive a perpetually fixed amount of rent, and their only obligation was to pay land tax. These practices were another aspect of the complexity and dynamism of the Chinese tenurial system

In imperial China, land transactions, especially the sale of land, were by deeds, as in English law. Deeds were essentially agreements, but was usually signed by the party giving effect to the land rights (for example, the seller) and by witnesses. They were then given to the party who received the land rights (for example, the purchaser) as proof of transfer of title. A deed would note the origin of the title and the background to the sale, and attach previous deeds relating to that land, known as shangshou qi 上手契. The chain of deeds established the title of the latest grantee of deed. A deed was thus a contract and a record of title.

That the deeds constituted proof of title was recognised by the government. A regulation of the Fujian Province clearly states that "according to customs, sale and pledge of property solely rely on the original deeds as evidence [of title]. If [a dispute] is submitted to officials for adjudication, [the officials] also rely on the deeds [to determine land ownership]". 50 This was so even if the parties failed to report and register the transaction as required by law. Regulations required that deeds of land sale had to be reported to the government and the land transaction recorded. This allowed the government to charge a transaction duty (qishui 契稅, stamp duty) as well as to keep accurate record of land holdings. The government affixed a stamp on the land deeds, which were called "red deeds" (hongqi 紅 契), as opposed to “white deeds" (baiqi 白契) which were not reported to the government and did not bear the government stamp. To evade the transaction duty some parties to land transactions did not report the transaction, and the seller remained on the register as the yezhu. In cases of dispute, even though they were white deeds, local officials still relied on

\footnotetext{
${ }^{49}$ Inō Taiwan wenhua zhi, above “Introduction” n 32, vol 2, at 329.

${ }^{50}$ Fujian shengli, above ch 3 n 53, at 442 “照得民間典䝴產業，全以原契為憑。而呈官剖斷，亦以契券 為據”。
} 
the deeds to ascertain land ownership, ${ }^{51}$ rather than giving effect to the land register and recognising the registered yezhu as land owner.

Therefore, land ownership operated independently from the relevant land register. Although the term yezhu literally means "proprietary owner", it was a term in the tax arena, not one in the property law arena. Being a yezhu on the government register was not a real indicator of land ownership, as property rights were determined by Chinese customary practice. The land tax registers were not title registers.

The implications of this tenurial system for aboriginal land rights in Taiwan are discussed below.

\section{Aboriginal Land Transactions}

\section{A Pu: an Overall Payment for an Unspecified Area of Land}

A term that was closely related to "lease" of aboriginal land but continued to evolve was $p u$. In Taiwan $p u$ originated from particular practices concerning aborigines. In the early Qing years the term was predominantly, although not exclusively, used in land transactions involving aboriginal land. ${ }^{52}$

\section{Early forms of pu}

There are two views regarding the origin of the term $p u$. One view is that it originated from the Dutch term pacht, which means monopoly. ${ }^{53}$ The other view is that $p u$ had a Chinese origin, and its southern Fujian dialect form pak means "to hire or rent for a long time, to charter or apprentice, to farm as revenue". ${ }^{54}$ Both meanings fit with the practice of the pushe system which emerged in Taiwan during the Dutch period. The Dutch controlled Han interaction with aborigines, and granted monopoly trading rights in aboriginal villages

\footnotetext{
${ }^{51}$ Sometimes surrounding circumstances were also considered in determining land titles. See Lin Wen-kai "“Ye ping qi guan'? Qingdai Taiwan tudi yezhuquan yu susong wenhua de fenxi" ['Deed determines ye'? An analysis on yezhu rights and litigation culture in Qing Taiwan] (2011) 18:2 Taiwanshi yanjiu 1, at 12 and 41.

52 Most $p u$ deeds in Dazu diaocha, above $\mathrm{n}$ 7, that was made before the early Qianlong reign related to aboriginal land.

${ }^{53}$ Kang Taiwan yuanzhumin shi zhengce pian: He Xi Mingzheng shiqi, above ch $1 \mathrm{n}$ 15, at 199.

54 Shepherd, above n 1 , at 474 , note 36.
} 
to Han merchants through auctions. Merchants who paid the highest bids to the Dutch authority won the monopoly to enter and trade in the aboriginal villages that they bid for. This was called pushe (贌社; she means village). ${ }^{55}$

The Zheng administration continued the pushe system, but with some adjustments. The Zheng government imposed a village tax on each aboriginal village that was under its administration. The village tax was paid by the Han merchants who had rights to trade in the villages. ${ }^{56}$ Thus pushe evolved from paying the price for monopoly trading rights to assuming the village tax by merchants who had monopoly trading rights. In both cases the essence of the system was tax farming.

The system of village merchants was abolished in the late Kangxi reign, because of complaints that the Han merchants exploited the aborigines. ${ }^{57}$ In the meantime, a new practice emerged, where Han settlers paid the village tax on behalf of the aboriginal villages in return for rights to reclaim the villages' land (daifan naxiang 代番納䬲). This was also called $p u .{ }^{58}$ Eventually the price for reclaiming aboriginal land increased, and apart from assuming village tax, Han settlers paid an additional amount as a "subsidy" (tie 貼) which the village could retain for village affairs or the villagers' provision. ${ }^{59}$ In some cases, the settlers did not report the reclamation to the authority at all. In other cases, the settlers applied for a land permit, while the aborigines produced a statement to say that the land in question did not violate aboriginal boundaries. ${ }^{60}$ In so doing the aborigines in effect relinquished their claims over the land.

\footnotetext{
55 A few Qing sources mentioned this system. For example, Yu Bihai jiyou, above ch $1 \mathrm{n}$ 24, at 36; Zhou, above n 18, at 102-103 and 168; Huang Taihai shichalu, above ch 1 n 25, at 163-165. For scholarly discussions on the pushe system during the Dutch period, see Kang, ibid, ch 12; Wu Tsong-min "Helan tongzhi shiqi zhi pushe zhidu" [The pushe system during the Dutch period] (2008) 15(1) Taiwanshi yanjiu 1-29; Wu Tsong-min "Pushe zhidu zhi yanbian jiqi yingxiang, 1644-1737" [The evolution and consequence of the pushe system, 1644-1737] (2009) 16(3) Taiwanshi yanjiu 1-38 (Wu "Pushe yanbian").

${ }^{56}$ Kang, ibid, at 272; Wu "Pushe yanbian", ibid, at 6.

${ }^{57}$ It was abolished by 1717 (Kangxi 56). See Zhou, above n18, at 168.

${ }^{58} \mathrm{Ka}$, above $\mathrm{n} 2$, at 92 .

59 At 280 and 283.

${ }^{60}$ At 282. Shepherd, above n 1, at 248-252 discusses "Paying the Tribal Tax in Exchange for Land" in detail.
} 
Few land deeds of the above described form of $p u$ are available now. An example of an agreement made in 1723 (Yongzheng 1) reads: ${ }^{61}$

The people who make this agreement, the village head of Dawujun village, Harou et al, have a piece of grassland, [four boundaries]. The four boundaries are clear. Because we cannot afford to pay the village tax, now [we] recruit Ding Zuozhou to invest in the irrigation and to [develop the land] into wetland. Today we negotiate in front of the Community Compact (xiangbao 鄉保) and the Interpreter [and reach the agreement that] from the $1^{\text {st }}$ year of the Yongzheng reign, the rent is 50 shi each year.... This will be the perpetual arrangement, and in the future [the parties] will not be incited by other people to dispute about it. If the tenants do not pay the rent in time or in full, it is Ding Zuozhou's responsibility and should not affect the aborigines. This [agreement is reached] by the two parties' free will, and neither would repudiate it. To have evidence, we sign this agreement.

This document, as did a few others of the same period, ${ }^{62}$ commenced with "the people who make this agreement" (li heyue ren 立合約人), and was signed by both parties. This is in contrast to deeds between settlers or later aborigine-settler deeds, which were signed by the grantor and usually specified the kind of business transaction by starting with "the person who recruits tenants" (li zhaodian ren 立招佃人) or “the yezhu who grants reclamation [rights]” (li zhaopi yezhu 立招批業主). Having both parties sign the agreement shows that there was probably a mutual distrust between the aborigines and settlers. The reference to future disputes because of third party involvement indicates that in the early stages of contact settlers and aborigines had different cultural understandings about contract terms which could lead to disputes. If this was the case, the problem soon disappeared, as bilateral agreements were replaced by unilateral deeds, following the practice among Han settlers. Further, the parties were either unsure, or deliberately vague, as to what kind of business transaction that was. The agreement specified the overall annual payment for land, of which the boundaries were recorded but the total area was not specified. Further, like the 1725

\footnotetext{
${ }^{61}$ Dazu diaocha, above n 7, at 326-327. Appended as Appendix 1(6).

${ }^{62}$ For example, see two other 1723 (Yongzheng 1) agreements and one 1730 (Yongzheng 8) agreement in ibid, at 5-6 and 325-328.
} 
deed quoted in Part IB, it tended to be vague on land rights of the parties. The annuity was in perpetuity (yongyuan dingli 永遠定例), but no other rights were mentioned.

The terms of deeds indicate that $p u$ at this stage essentially meant to pay a perpetually fixed amount of annual grain or money (sometimes with an initial payment), in return for the rights to reclaim a piece of land, which was defined by boundaries but the number of jia was unknown. Since the transaction was a "bulk $p u$ ", that is, an overall annuity for an unspecified area of land, usually the Han settlers divided and leased the land, and became large rent holders themselves. These were the situations which Ka calls "aboriginal rent over large rent". ${ }^{63}$ The reference in the above agreement to tenants' payment of rent as Ding's responsibility shows that the aborigines were aware that Ding intended to "sublease" the land. In essence the transaction was a land grant, but the initial grantor and source of title was the aborigines, not the government.

\section{Registration of aboriginal land}

Because the Han party of the "bulk $p u$ " was essentially the grantee of land, potentially they could become registered yezhu. Ka argues that the government imposed the registration requirement on Han settlers who " $p u$ " aboriginal land. The basis of this view is the Governor-General's recommendations in 1725 (Yongzheng 3) that "the aboriginal deer grounds are mostly vacant, and [the government] should let the aborigines lease the land to Han settlers to reclaim and cultivate, and eventually to register for tax" ${ }^{64}$ This section re-examines this issue.

Registration of aboriginal land by settlers had occurred before 1725. Chapter 3 discussed a decree issued in 1704 (Kangxi 43) by the Taiwan Circuit Intendant, Wang Minzheng, which required settlers to fulfil contractual obligations with aborigines. The decree also required registration of land for which settlers contracted with aborigines. As has been shown in previous chapters, the style of Qing law and policy-making often makes it difficult to ascertain the starting point of a law or policy, and surrounding evidence needs

\footnotetext{
${ }^{63} \mathrm{Ka}$, above $\mathrm{n} 2$, at 280 .

${ }^{64}$ At 107-108. See the recommendation, approved by the Emperor, in Shizong shilu, above ch 2 n 46, at 1213 , “各番鹿場頗多閒曠, 應聽各番租與民人墾種, 陸續陸科”.
} 
to be considered. For example, Chapter 3 showed that government policies protecting aboriginal land were often repeated several times, without reference to similar policies made earlier. It is likely that local officials presumed that Han settlers needed to pay land tax once land was reclaimed, even though there was no specific regulation to deal with the situation of Han reclamation of aboriginal land. The 1725 recommendation was discussing eight aboriginal villages in the Fengshan County. Against the historical and immediate contexts it is difficult to conclude that the recommendation imposed a new requirement.

Once the land was on the government register and the Han settlers were recorded as yezhu, it does appear that the nominal connection between the aborigines and their land was severed. However, as already demonstrated, land rights generally were defined by contractual arrangements rather than land registration. Aboriginal land rights were no exception. In the $p u$ deeds, the aborigines often forfeited rights over land, and only retained rights to collect an annuity. Despite Han registration of aboriginal land, the annuities agreed upon between aborigines and settlers were observed even with the passing of time and further sale of land. This is shown in many land deeds which recorded that the land in question owed an annual "aboriginal rent". ${ }^{65}$ Therefore, private land transactions and government land registration continued to operate in parallel, one determining property rights, and the other tax obligations. The key to land loss was the land transactions between settlers and aborigines, not land registration.

\section{B Aboriginal Large Rent}

1 The emergence of aboriginal large rent

$P u$ of aboriginal land continued to evolve, as is shown by an often quoted Lower Tamsui deed of 1721 (Kangxi 60): ${ }^{66}$

1) The people who make this agreement, Lower Tamsui village head Aremo and [names] et al, had one parcel of grassland. In the $46^{\text {th }}$ year [of the Kangxi reign,

\footnotetext{
${ }^{65}$ Many land deeds in Dazu diaocha, above n 7, have such a term. For an example, see ch 3.11 "Other deeds". ${ }^{66} \mathrm{Li}$, above $\mathrm{n} 8$, at 359. The ellipses indicate words missing from the original document. Paragraph break and numbering added. Appended as Appendix 1(7).
} 
1707], because [sic] He-Zhou-Wang recruited ...Fu Ruduo, Fu Chengsu et al and reclaimed [the land which is now] the Tonobot estate (Dunwu zhuang 頓物莊).

2) Later the people of our village disputed with He-Zhou-Wang. Thanks to the previous county magistrate Song's adjudication, the Tonobot estate was given to the aboriginal people to pay tax (guiyu fanmin wanke 歸於番民完課). On that day the aborigines and the tenants made an agreement. The labour and capital investments for irrigation systems are all the responsibilities of the tenants. After the land was developed into wetland, the yezhu ... 15 jia .... The annual rent was seven shi per jia, [and the rent] had been delivered to the village granary without problem.

3) In the $59^{\text {th }}$ year [of the Kangxi reign, 1720], because the population of the village had increased, [the village] requested to the tenants for increase of rent. This was brought before the county magistrate $\mathrm{Li}$, who adjudicated for two shi [per jia] increase of rent..., and the aborigines and tenants both accepted [the decision]. The rents for the Tonobot estate, including the additional rent from the [magistrate's] decision, were being received in full.

4) But now the people of our village had no means to pay for official businesses, and [we] borrowed $700 s h i$ of grain from the tenants...pay tax... are willing to deduct 1.5 shi per jia each year as interest.

5) On this date the yezhu and tenants agreed that each year the rent is 7.5 shi per jia. The tenants transport [the grain] to our village's granary. This is a perpetual arrangement. In the future if the tenants want to invest elsewhere or go back to China, they are free to reassign the sub-soil [rights] to [recover] labour and capital investment, and the yezhu should not make trouble again.

It was standard practice for land deeds to recount the history of earlier transactions, as this deed also exemplifies. Paragraph (1) reveals that at a time before 1707, the aborigines had an agreement with He-Zhou-Wang about the land, who then recruited tenants to reclaim the land. The deed does not disclose what arrangement was made between the aboriginal village and He-Zhou-Wang in the first place. Given the customary practice of that time and the statement that He-Zhou-Wang recruited tenants, very likely He-Zhou-Wang had "bulk 
$p u$ " the land from the aboriginal villages and had then granted a lease in large rent to the tenants.

Paragraph (2) of this deed shows that, after the reclamation was completed, a dispute arose between the village and He-Zhou-Wang as to who was entitled to receive the rent from the tenants. ${ }^{67}$ Magistrate Song (1704-1712) adjudicated the land to the aboriginal village and the aborigines became registered yezhu, and were responsible for land tax payment, while He-Zhou-Wang lost connection with the land. ${ }^{68}$ The rent was fixed at seven shi per jia. This was close to the rate of eight shi which became the prevalent large rent rate later on. Together with the fact that the aborigines were registered as yezhu, a large rent relationship akin to that between Han settlers was established. However, it is not clear whether the tenants acquired any substantive property rights at that stage.

Paragraph (3) records that in 1720 the aborigines were successful in winning another magistrate's support to increase the rent to a level which was higher than the customary rate. No further rights or obligations are mentioned. Paragraph (4) explains that a loan in 1721 caused the parties to re-negotiate, and paragraph (5) shows that the tenants managed to establish perpetual and independent proprietary rights. The large rent relationship thus evolved to the next step, and split ownership was established.

Therefore from the initial agreement with He-Zhou-Wang to the agreement in 1721, the transaction evolved from "bulk $p u$ " to a large rent relationship without specifying the tenants' property rights, to in the end the tenants acquiring independent property rights. The second and third steps mirrored the large rent model between Han settlers. This deed

\footnotetext{
67 The reason for the dispute is unclear. It could be because the reclamation was not consistent with the agreed contractual terms (for example, exceeding the specified boundaries), or because the aborigines repudiated the agreement, or both.

${ }^{68}$ Shepherd, above $\mathrm{n} \mathrm{1}$, at 252-254, and Ka, above n 2, at 338-341, both discuss this deed. However both neglect the role of He-Zhou-Wang. Consequently, Shepherd finds the passage "difficult to interpret" (at 254). $\mathrm{Ka}$ argues that the tax referred to in the deed was not land tax, and the adjudication was to provide an income to support the aborigines for payment of village tax. However the phase "guiyu fanmin wanke" and the reference of yezhu suggest that the village was responsible for the land tax and had registered the land for tax after the adjudication. Shepherd is also of the view that the adjudication established a large rent relationship between the aborigines and the settlers, but sees it as Magistrate Song's imposition.
} 
thus demonstrates the evolving types of transactions by which the aborigines disposed of their land, and the emergence of aboriginal large rent model.

A 1727 (Yongzheng 5) deed between the aboriginal village of Katin (Jiateng 茄藤) and Han settlers had similar arrangements to the 1721 deed. The aborigines promised that the seven shi per jia of annual rent was to be fixed for perpetuity, and the Han tenants had the freedom to sell the subsoil rights. ${ }^{69}$ However, a deed of 1732 (Yongzheng 10) between an aboriginal landlord and his tenant still allowed the landlord to replace the tenants where rent was in arrears. ${ }^{70}$ This shows that the arrangements were not uniform or clear cut, as the land reclamation relationships among Han settlers generally were. In general the development of the large rent model between Han settlers and aborigines followed the same pattern as among Han settlers.

\section{Registration of land}

Where aborigines leased their land in large rent, potentially they were on a similar footing as Han large rent holders. They could register their land and become registered yezhu. In 1730 (Yongzheng 8), the Taiwan Circuit Intendant, Liu Fanchang, recommended to the Emperor that the aborigines be encouraged to reclaim their grasslands and register the land for taxation. ${ }^{71}$ According to Ka, this brought fan yehu (番業户 “registered aboriginal title holder") into existence. Ka argued that once aborigines registered their land, the land was no different from settler land and could be bought and sold. Ka hence attributed registration of aboriginal land by aborigines as one of the main reasons that caused the aborigines to lose their land. ${ }^{72}$ This proposition calls for close examination.

In practice, cases of aborigines registering land and paying land tax emerged before 1730 . The 1721 Lower Tamsui deed, quoted above, mentioned land tax responsibility on the aboriginal village and referred to it as yezhu. This means that registration of aboriginal land by aboriginal villages had started as early as 1712 when Song adjudicated the case. A public

\footnotetext{
${ }^{69}$ See the deed in $\mathrm{Li}$, above $\mathrm{n} 66$, at 363.

${ }^{70}$ At 376.

${ }^{71}$ See the memorial in Ming Qing dang'an, above "Introduction" n 55, vol 13, at 286.

${ }^{72} \mathrm{Ka}$, above n 2, at 287-290.
} 
notice, issued by the Zhanghua magistrate in 1730 (Yongzheng 8) concerning the sale of a piece of aboriginal land, noted that the aboriginal Dongluo village had created an account (lihu 立户) as land title holder, and registered the land in question under the name of the created account. ${ }^{73}$ The sale occurred in the same month as Liu's recommendation, but by then the registration had been on record (zai'an 在案). ${ }^{74}$ These examples show that the aborigines had started to register land before Liu's recommendation.

Further, there is no evidence to suggest that Liu's recommendation was carried out as a mandatory requirement. The Emperor advised Liu to consult with the Fujian Governor and Fujian-Zhejiang Governor-General and trial the suggestion cautiously. ${ }^{75}$ This shows the Emperor's reluctance to systematically change the practice of aboriginal land tenure. In fact a Circuit Intendant noted in 1788 (Qianlong 33) that "in Taiwan aboriginal land has not been subject to land tax by law" - which meant no requirement of registration — and the only exception was in Danshui Sub-prefecture where the Sub-prefect required registration by mistake. ${ }^{76}$ The registration of aboriginal land in practice and the official record show that, even though no law had required registration, the aborigines had adopted Han practice and were becoming registered yezhu. It is likely that the aborigines registered their land voluntarily, probably with the intention of protecting their land from Han encroachment and from manipulation by Interpreters. ${ }^{77}$ In practice some officials probably also encouraged or required aborigines to register their land for revenue reasons, as the Danshui Sub-prefect did.

\footnotetext{
${ }^{73}$ Dazu Diaocha, above n 7, at 600-601.

${ }^{74}$ Both the memorial and the land sale occurred in the third month of Yongzheng 8.

75 See the Emperor's rescript in Ming Qing dang'an, above n 71, at 286.

76 “臺郡番地原無征賦之例”. See the decree issued by the Taiwan Circuit Intendant, Zhang Ting, in Sifa cankao, above ch 2 n 122, vol 1A, at 293. Ka, above n 2, at 292-293, argues that Zhang was mistaken since aboriginal registration of land had emerged in 1730. However, 例 (li) could mean "example" or "precedent", but it was also an important form of legislation, as discussed in ch 2. Here Zhang meant no law on aboriginal land tax, rather than no example.

${ }^{77}$ Taiwan sifa, above $\mathrm{n} 35$, at 207, is of the view that fan yehu was designed to protect aboriginal land rights. Shepherd, above n 1, at 293, argues that without registration the aborigines' claims to land were weakened.
} 
During the early to mid-Qianlong reign, a system of appointing fan yehu by the government was established. ${ }^{78}$ This means that a fan yehu was not only an account for land registration, but also a person who held office in the village. Fan yehu were nominated by villagers, checked by officials and appointed by the government. ${ }^{79}$ They were responsible for granting village land to settlers for reclamation, collecting annual grain from settlers, distributing the grain to villagers, and paying land tax. ${ }^{80}$ The main reason of appointing fan yehu was because interpreters had dominated village affairs and embezzled village rental incomes in many cases. ${ }^{81}$

Because of the mechanism of yehu and fan yehu, registration by aboriginal villages did not of itself cause land privatisation among the aborigines. Under the Qing registration system, there was no particular requirement as to the legal personality of a registered title holder. It could be an individual, a firm, a partnership, or any other loose organisation, as long as there was a $h u$ (户 , literally "household", but more accurately, an account) on the register. ${ }^{82}$ This means that aboriginal villages could create an account and continue to hold the land in collective. With the system of fan yehu, the aboriginal villages registered the land under a representative, and their internal operations were not affected.

Land registration did not materially affect aboriginal land tenure, nor did it facilitate alienation of land by aborigines. The aborigines sold their land regardless of registration. Sale of aboriginal land was never explicitly allowed, and was in fact explicitly banned in 1737 (Qianlong 2). Existing records show that the aborigines sold their land before 1737, and that in most of these cases the land was not registered. For example, in 1724 (Yongzheng 2), an aboriginal village granted reclamation rights of a piece of land to a

\footnotetext{
${ }^{78}$ Taiwan sifa, ibid, at 207 estimates that fan yehu emerged in the early Qianlong years, and Tai Qingdai Taiwan zhi xiangzhi, above ch $3 \mathrm{n}$ 84, at 394, states that it emerged in 1757 (Qianlong 22). Based on the argument that registered title holder emerged in 1730, Ka, above $\mathrm{n} \mathrm{2,} \mathrm{at} \mathrm{286,} \mathrm{rebukes} \mathrm{the} \mathrm{findings} \mathrm{of} \mathrm{Taiwan}$ sifa and Tai. However the discussion of those two studies was on fan yehu as an office holder, therefore there is no conflict.

${ }^{79}$ Tai, ibid, at 394-395.

${ }^{80}$ At 395.

${ }^{81}$ At 394.

${ }^{82}$ For example, the yehu Chen-Lai-Zhang that reclaimed the Taipei basin was an account name representing three people whose last names were Chen, Lai, and Zhang respectively. See Yin Zhang-yi Taiwan kaifashi yanjiu [Research on the history of land reclamation in Taiwan] (Lianjing, Taipei, 1989), at 65-67.
} 
settler, who then sold the rights (zhuanshou 轉售) to another person. Two years later, the village sold the residual rights (rent collection rights) to the new grantee. The deed made by the village was entitled “deed of irrevocable sale” (dumai qi 杜賣契). The aborigines allowed the purchaser to register the land for tax, which implies the land had not been registered prior to this. The aborigines also promised that "after the sale all [rights] are forgone” (yimai qianxiu 一賣千休). ${ }^{83}$ A “deed of sale” (maiqi 賣契) in 1734 (Yongzheng 12) had the same essential terms, but the purchaser promised to pay an annuity of 40 taels of silver to the village, in addition to the sale price. ${ }^{84}$ In contrast, after 1737 , no record of outright sale of village collective land is available, and almost all sale of large rent rights was by village heads or interpreters on behalf of the villages, or by individual aborigines, rather than fan yehu. ${ }^{85}$ This was despite the fact that after 1740 (Qianlong 5) fan yehu was active in granting leases in large rent. ${ }^{86}$ Further, the aboriginal villages continued to grant leases in large rent through village heads, Interpreters or by village assemblies during the Yongzheng and Qianlong reigns, and there is no indication that the practice was replaced by the fan yehu system. $^{87}$

In summary, there was no positive law that required registration of aboriginal land by aborigines, although local officials might have encouraged registration in individual cases. Registration of aboriginal land by aborigines operated in tandem with aboriginal customary land tenure, and did not of itself change the actual tenure. After registration the villages still owned the land collectively, and the fact that the registered land was aboriginal land remained identifiable. The aborigines lost proprietary rights when they leased land in large rent, and lost rent collection rights once they sold the yezhu rights. In any case, villages leased land in large rent and sold rent collection rights regardless whether the land was registered or not. The main issue was not land registration, but private land transactions.

\footnotetext{
${ }^{83}$ See the deed in Dazu diaocha, above n 7, at 328-330.

${ }^{84}$ At 330-333.

${ }^{85}$ In the 38 deeds of sale or pledge by aborigines collected in ibid, ch 3.10 "Deeds of sale and pledge" concerning aboriginal large rent, only one deed (No 7) was given by a fan yehu.

${ }^{86}$ See ch 3.4 "Land grants by fan yehu".

${ }^{87}$ See ch 3.2 "Land grants by aboriginal villages".
} 


\section{Privatisation of land}

With spread Han settlement and increasing exposure to Han culture, voluntary privatisation of land by aborigines occurred and became wide spread.

Available records show that aboriginal private land ownership existed in the early years after Qing annexation. A fragment of a land deed in the early Kangxi years recorded the sale of land by a villager of the aboriginal Mattau village, most likely to another individual aborigine. ${ }^{88}$ Mattau was one of the four sinicised villages during the Zheng time, and would have been influenced by the Han concept of private ownership, although the extent of privatisation by that time was likely to be limited.

Throughout the Yongzheng, Qianlong and subsequent reigns, individual aborigines sold or granted their lands to Han settlers for reclamation, and the lands were usually "inherited from forefathers" (youcheng zufu yixia 有承祖父遺下). ${ }^{89}$ However, the practice of dividing up village land and distributing it to individual households became relatively common only after the mid-1700s. ${ }^{90} \mathrm{~A}$ well-documented example was the experience of the Anli villages.

Privatisation of land in the Anli villages was directly influenced by the Interpreter of the villages, who was a Han land investor. The Anli villages were a group of nine villages that occupied the central western plains, and the biggest one was the Anli village. In 1716 (Kangxi 55) a group of five villages, led by the village head of the Anli village, submitted themselves to the government, and petitioned for a land grant in the plains area. ${ }^{91}$ Scholars believe that their Interpreter, Zhang Dajing, was the person behind this petition. ${ }^{92}$ Zhang was the Interpreter of the Anli villages for many decades, as well as the son-in-law of the village head of Anli. Under Zhang's guidance, the villages kept some land as collectively

\footnotetext{
${ }^{88}$ Since the deed was in Sinkang language only, it is likely that both parties were aborigines. See the deed in $\mathrm{Li}$, above n 66, at 541.

${ }^{89}$ See the deeds in Dazu diaocha, above n 7, ch 3.3 .

${ }^{90}$ Chen, above $\mathrm{n} 31$, at 7 .

${ }^{91}$ At 26-36. See Sifa cankao, above n 76, vol 1A, at 319-320 for a notice of grant.

${ }^{92}$ Chen, ibid, at 32; Huang Fu-san "Anli she yu Hanren hezuo kaifa Qingdai Taiwan zhongbu de lishi yuanyuan" [The history of the cooperation between the Anli villages and Han settlers to reclaim central Taiwan during the Qing Dynasty] (1998) 16(2) Hanxue yanjiu 61, at 74.
} 
owned, leased the land to settlers in large rent, and used the income to pay village tax and for village affairs. ${ }^{93}$ The remaining land was divided up and distributed to individual households. Very often the aborigines simply leased their lands to Han settlers in large rent and lived on the annuity. ${ }^{94}$ They then further pledged rent collection rights to settlers, which they were often unable to redeem. ${ }^{95}$

The Anli villages' experience was but one salient example. Privatisation of aboriginal land appeared to be widely practised among the acculturated aborigines. For example, most land in the two Dajia villages in the central western plains was privately owned during the Qianlong reign. ${ }^{96}$ Once the land was divided, it was likely to be leased, pledged or sold to settlers, since individual aborigines had little means to sustain themselves. ${ }^{97}$ Furthermore, while land leased by villages as a collective or by fan yehu as representative of the villages was recognisable as aboriginal land, without the context of the aboriginal community system, individual aborigines' land was more difficult to be recognised as aboriginal land.

Another type of privatisation was to divide up village rent after the land was leased by the village as collective property. This was usually because of complaints that village heads, Interpreters or fan yehu embezzled village rent, and as a solution individual aborigines were given a share of the rent which they were entitled to collect from the Han tenants. ${ }^{98}$ The effect of assigning rights to collect rents from a certain tenant or a certain plot of land to individual aborigines was in effect no different from dividing up land which the aborigine then leased in large rent. This was a means that the aborigines tried to protect their rental income from being squandered by the village office holders. However, because of difficulties in collecting rents or other financial difficulties, individual aborigines often ended up selling or pledging the rent collection rights.

\footnotetext{
93 Chen, ibid, at 63.

94 At 69-70.

95 At 192.

${ }^{96}$ Liu Dajia dongxishe guwenshu, above n 9, at 137.

${ }^{97}$ See Dazu diaocha, above n 7, ch 3.3 and 3.10 for individual aborigines' lease of land in large rent, and sale or pledge of large rent rights.

98 The details will be further discussed in ch 5 .
} 
Therefore privatisation of aboriginal land, usually voluntary and without government intervention, sped up land loss by aborigines and caused the most damage to aboriginal land tenure.

\section{Land Transactions and Loss of Land}

Land grants by aborigines thus went through a process of development from "bulk $p u$ " in return for assumption of village tax or an overall payment, to the Han large rent model; from no specific definition of the parties' rights and obligations to defining property rights; from allowing land registration by settlers to assuming the status of yezhu by aborigines; from land grant by villages under their collective decision-making system to a mechanism of fan yehu, and to individualisation of land ownership. No matter whether "bulk $p u$ " or lease in large rent, the effect was permanent alienation of land. The whole process closely followed Han practice, and as in the case of non-aboriginal land, registration did little to change aboriginal land tenure.

The evolution of aboriginal land transactions and land tenure changes demonstrate the increasing awareness of land values by the aborigines. More importantly, it shows the increasing influence of Chinese commerce and land practice. As discussed in Chapter 1, the deer hunting and farming activities of the Taiwanese aborigines were at subsistence level only. Since the Dutch period, the Chinese settlers were "the only bees on Formosa that gave honey", meaning the only source of government revenue. ${ }^{99}$ Under the Zhengs, village tax was assumed by village merchants. After the Qing annexation, the aborigines had difficulty affording village tax and living needs, and without deer economy they were content to give up large areas of deer hunting grounds in return for subsidies for tax and living support. With the increasing competition for land and the spread of Han settlement and practice, the aborigines adapted and tried to participate in land reclamation activities. However the Chinese style of farming was intensive and usually wetland farming, which required capital investment on irrigation systems. This was beyond the aborigines' ability. Therefore they followed the prevalent Han practice and leased land in large rent to settlers. Settlers were responsible for capital and labour investments, and the aborigines became

\footnotetext{
99 Andrade How Taiwan Became Chinese, above ch 1 n 80, at 158, quoting a Dutch Governor of Taiwan.
} 
mere receivers of fixed large rent. Privatisation was also a result of cultural influence, as well as pragmatic response to issues within the aboriginal community.

The aborigines lost their substantive land rights through granting "bulk $p u$ " or large rent to setters, and retained rent collection rights only. Many further sold or pledged the rent collections rights and lost any connection with the land. There was very little government involvement in the process, and little could the government control the process. In fact, as will be demonstrated in the next Part, because of government laws and policies which forbade sale and pledge of aboriginal land, Han settlers and aborigines used other forms of deeds to evade the laws and policies.

\section{Confusing Concepts: Pu, Dian, Mai}

While at times the government allowed lease of aboriginal land, sale of aboriginal land was never expressly allowed, and regulations usually forbade dianmài (典䝴 pledge and sale) at the same time. The ban was not always complied with, but in most cases, private transactions evaded laws through $z u$ or $p u$ of their land, which at times had no material distinction from dian and sale. Part II discusses the use of $z u$ and $p u$ to alienate aboriginal land, and this Part examines the transactions of dian and sale, as well as the further evolution of $p u$.

\section{A Dian and Sale}

Dian 典 was to surrender one's property as a pledge, in return for a loan. ${ }^{100}$ In a dian transaction, the land was surrendered when the money was delivered, and there was no requirement of paying interest or rent from either side. This was to be distinguished from tai 胎, which was also a form of guarantee for loans. In a tai relationship the land owner surrendered land deeds as a guarantee while continuing to possess the land, and paid interest on the loan. ${ }^{101}$ Tai was similar to the concept of mortgage in modern practice, while dian was similar to a pledge. Tai was a straightforward relationship, although the high

\footnotetext{
${ }^{100}$ Zhao and Chen, above n 47, at 24; Wang, above n 34, at 84-85; Taiwan sifa, above n 35, at 344.

${ }^{101}$ Taiwan sifa, ibid, at 367-380.
} 
interest rates that Han settlers charged sometimes caused government intervention. In contrast, dian was a type of conveyance and could be confused with sale at times.

To illustrate the nature of dian, an example of a typical deed of dian reads: ${ }^{102}$

The person who gives this deed of pledge, Chen Zhou of Xiashuizai village, has a piece of wet land, [location and boundaries in four directions]. Now [Zhou] lacks money for other enterprise, [and he] has asked all relatives [who confirmed that they] would not receive (chengshou 承受) it. Through intermediary [Zhou] found Chen Yulin from his own clan, who is willing to accept the pledge (chengdian 承典). On this day the three parties [land owner, lender and intermediary] agree that [the land] is worth 150 dollars in silver. The silver is given and received on this day in front of the intermediary; the land is then given to the lender to manage and to recruit tenants to cultivate. There is an annual large rent of one shi, and water rent of four $d o u .^{103}$ The land [is pledged] from [1804 to 1814], [after that] Zhou can repay the silver specified in this deed of pledge [meaning the loan amount], and take back the original deed. If Zhou does not have the silver, he will allow the lender to [continue to] cultivate and shall not harass [the lender]...

In this deed, the land owner relinquished control and management of the land, and any responsibilities attached to the land, such as paying large rent and water rent, in return for a loan assessed at the value of the land. As in the case of sale, the land owner gave his close relatives right of refusal. During the ten-year period, the lender had full control of the land, paid rents, and enjoyed the full produce of the land. It was as though the transaction was sale and purchase, the only difference being that the debtor had the right to buy back the land at the original price after the term was due. Therefore to some extent dian was "similar to sale with an agreement for redemption when the term was due". 104 As was typical of dian, in this deed the debtor was not obliged to redeem after the ten-year term expired, in which case the deal would continue. The term of redemption was to exclude the

\footnotetext{
102 Dazu diaocha, above n 7, at 217-218. Appended as Appendix 1(8).

103 One dou is 0.1 shi.

104 Wang, above n 34, at 84-85.
} 
debtor from redeeming the land within the fixed period of time. ${ }^{105}$ The term of dian could be very long, and it was not unusual for a contract to omit the term of dian. If the contract did not specify the term, or if the debtor could not repay the loan after the term expired, the creditor could continue to possess and use the land until the debtor was able to redeem. Within the term of dian, the pledgee could transfer the rights on the land to others, which was called “assigning pledge” (zhuandian 轉典). ${ }^{106}$

Therefore, dian was a land transaction itself, and when the dian relationship was established, the land owner lost the land temporarily, which could become permanent if the duration was too long, or if the debtor did not redeem.

Dian could be confused with sale, which was often a temporary and revocable transfer of rights. In Qing Taiwan, as in imperial China, there were two types of sale, irrevocable sale (juemài 絕賣) and revocable sale (huomài 活賣). ${ }^{107}$ Irrevocable sale meant the modern meaning of sale, while revocable sale allowed the seller to request a price top-up or to redeem the land at the original price, even though many years had passed. ${ }^{108}$ In reality, there were also examples where price top-up was requested and paid in irrevocable sales. ${ }^{109}$ Therefore even with sale, there were different degrees of forgoing one's rights on the land, and there was no material difference between dian and revocable sale, especially when the deed of dian did not stipulate a time limit.

Probably because of the similarity between dian and sale, the Qing regulations treated both dian and sale as land transactions. Early regulations required change of registered title holder (guoge 過割) and payment of contract duty in both cases of pledge and purchase

\footnotetext{
105 Terada, above n 11, at 363.

106 Ibid. Also see Taiwan sifa, above n 35, at 350.

${ }^{107}$ For explanations of irrevocable sale and revocable sale, see Peter Hoang "Law of Land Tenure in China: A Practical Treatise on Legal Ownership" (Part 1) (1922-1924) 1 China L Rev 90, at 93. Also see Terada, above $\mathrm{n} 11$, for an analysis of the real nature of revocable and irrevocable sales.

108 There were cases where the sale did not became irrevocable until after over 70 years. See Mio Kishimoto "Ming Qing shidai de zhaojia huisu wenti" [The issue of price top-up and redemption during the Ming and Qing dynasties] in Yang and Terada (eds), above n 11, 423, at 426.

109 At 425; Edward Kroker "The Concept of Property in Chinese Customary Law" (1959) Ser 3 vol 7 Transactions of the Asiatic Society of Japan 123, at 145-146.
} 
(dianmai 典買), while also trying to enforce debtors' right of redemption. ${ }^{110}$ This was also the reason why dian and sale were banned at the same time.

Consistent with the government ban, available land deeds show that outright sale or pledge of aboriginal land was very rare. More usually unreclaimed land was leased in large rent, and the aborigines may subsequently sell or pledge the rent collection rights. ${ }^{111}$ Another way to evade the ban was through taking advantage of the similarity between sale and dian, and between dian and the evolved $p u$. Often through deeds of $p u$ aborigines dian their land, which had the potential to become sale and led to loss of land by the aborigines. This usually occurred in cases of reclaimed land.

\section{$B \quad$ Dian and $\mathrm{Pu}$}

\section{$1 \quad$ Further evolution of $\mathrm{pu}$}

The meaning of $p u$ continued to evolve, and later it referred to periodic tenancy, which became the predominant meaning of $p u .{ }^{112}$ The extension or transformation of the meaning possibly went through a gradual process in customary practice, and the first record of recognising $p u$ as periodic tenancy was in the late Qianlong reign. As was typical under the Qing system, official usage of the terms often followed, rather than guided, the practice. In 1788 (Qianlong 53), the Anli village petitioned the Aboriginal Affairs Northern Subprefect and claimed that their land was "temporarily $p u$ to Han settlers for two or three years". ${ }^{113}$ The Sub-prefect endorsed this claim and talked about the expiry and renewal of pu contracts. ${ }^{114}$ This was the first time the government regulated periodic tenancy, ${ }^{115}$ and as a side effect made it clear that $p u$ meant, or included the meaning of, periodic tenancy. In 1800 (Jiaqing 5), another local government decree stipulated that where Han settlers pugeng (贌耕“lease for cultivation”) aboriginal land, at the end of three years, settlers must

\footnotetext{
${ }^{110}$ Regulations of the Ministry of Households, in Sifa cankao, above n 76, vol 1B, at 125.

111 As already discussed. Also see deeds in Dazu diaocha, above n 7, ch 3.2, 3.3, 3.4, and 3.12.

112 Taiwan sifa, above n 35, vol 1, at 96-97 and 106-108. The Japanese investigation of customs found that $p u$ had a fixed term, and that the type of $p u$ that gave tenants perpetual rights over land was not real $p u$.

113 “暫贌漢人代耕，二三年限滿取回”. Dazu diaocha, above n 7, at 768.

114 Ibid.

115 Ka Chih-ming "Fanxiaozu de xingcheng yu yanbian: Anli xinshe diyu shefan kouliangtian de zudian anpai" ("Formation and Transformation of Aborigine Small-rent Tenure: Land Tenancy of Tribesman's Ration Plot in Anli New Territory”) (2008) 15(3) Taiwanshi yanjiu 57-137, at 68, note 35.
} 
return the land to the aborigines who could decide to cultivate it themselves or to lease it to other tenants. ${ }^{116}$ This accords with the fact that the term $p u$ was used increasingly in periodic tenancy deeds from the early Jiaqing reign. ${ }^{117}$ By 1870 , the only meaning of $p u$ seemed to be periodic tenancy, as it was recorded that where tenants $p u$ land from field owners, once the term expired, the field owner could $p u$ the land to someone else. ${ }^{118}$ Periodic tenancy had the feature of giving up use of land for a period of time, a feature shared by dian.

\section{$2 \mathrm{Pu}$ in name but dian in essence}

Existing deeds show that the actual transactions of short term $p u$ were very similar to dian. An example of a typical short term $p u$ reads: ${ }^{119}$

The people recruit [tenants for] cultivation and give this deed of yadi [money], Ponan Weishuo and Qiankun Weishuo, together inherited two adjacent pieces of reclaimed dry land (shuyuan 熟園), [location and boundaries]. The four boundaries are clear, and having been measured [by land owner] with the Interpreter and the village head, the area is three jia. The rent is 12 shi of grain per year. Now because the land is far from the village, [the owners] are not able to cultivate it. After consulting relatives in the village, [the aboriginal relatives] could not cultivate it either. Through an intermediary [the owners] found a Han person Yang Congguan [who is willing] to cultivate. [The owners] receive yadi money 400 dollars. On this day the money is received, and the land is given to Yang Congguan to cultivate for 20 years. The aborigines are the yezhu, and the Han person is the tenant. Every year [the tenant] shall prepare 12 shi of grain for the aborigines to take away, and should not be in short or late. When the term is completed, the Weishuos will give back the yadi money and take back the original deed, [the tenant] should not make it difficult [for the land owners]. If the money is not returned, [the land] is given to the money owner (yinzhu 銀主) to continue

\footnotetext{
${ }^{116}$ Dazu diaocha, above n 7, at 769-770. The decree was issued in 1810, also on the Anli village's petition.

${ }^{117}$ See land deeds in ibid, at ch 2.2, 3.12, and 656-657.

${ }^{118}$ Chen Danshui tingzhi, above ch 2 n 115, at 297.

${ }^{119}$ Dazu diaocha, above n 7, at 754-755. This deed was made in 1798 (Jiaqing 3). Appended as Appendix $1(9)$.
} 
cultivation, and do whatever he wants to do (rencong qibian 任從其便), and [the Weishuos] dare not dispute...

In Chinese practice, alienation of land must give the seller's close relatives the first right of refusal, while a tenancy did not have such a requirement. The mention of right of refusal by relatives in this deed suggests that it was not a true tenancy. Another indicator was in the payment of yadi money (yadiyin 壓地銀), also called qidi money (qidiyin 碃底銀). Yadi money was usually used in short-term tenancies, being a sum paid at the time of agreement and returned when the term concluded. It is commonly understood to be a bond, to guarantee payment of rent, as well as to prevent the landlord from repudiating the agreement. ${ }^{120}$ Scholars have found that the amount of qidi money was usually about one year's rent, and on average $70 \%$ of annual rent. ${ }^{121}$ However, in the above agreement, the qidi money was 33 times the annual rent. ${ }^{122}$ Therefore the transaction was more like dian than periodic tenancy. Chart 17 shows the key terms of a collection of aborigine-Han tenancy agreements, most of which show characteristics of dian.

\footnotetext{
${ }^{120}$ Chen, above n 31, at 97.

121 At 97-98, and note 40.

${ }^{122}$ The grain price varied over time, but one dollar is roughly the value of one shi of grain. See ibid, at 96.
} 
Chart 17 Key Terms of Aboriginal-Settler "Tenancy” Deeds (Source: Dazu diaocha, ch

\subsection{2 pugeng $z i$ 瞨耕字)}

\begin{tabular}{|l|l|l|l|l|}
\hline $\begin{array}{c}\text { Year of } \\
\text { Deed }\end{array}$ & Qidi money & \multicolumn{1}{|c|}{ Rent } & \multicolumn{1}{|c|}{ Term } & \multicolumn{1}{|c|}{ Others } \\
\hline 1798 & 400 dollars & 12 shi of grain & 20 years & $\begin{array}{l}\text { Can continue cultivation if owner did not pay } \\
\text { back qidi money. }\end{array}$ \\
\hline 1803 & 45 dollars & 2 shi & 10 years & As above. \\
\hline 1807 & 120 dollars & 1 shi & 20 years & As above. \\
\hline 1812 & 75 dollars & 0.5 shi & 5 years & $\begin{array}{l}\text { As above. Land owner then borrowed 23 dollars } \\
\text { in three subsequent occasions. No other terms } \\
\text { changed. }\end{array}$ \\
\hline 1826 & 10 dollars & 2 dollars & Not specified & $\begin{array}{l}\text { Tenant should give the land back if not } \\
\text { continuing. }\end{array}$ \\
\hline 1827 & 30 dollars & Not specified & 13 years & $\begin{array}{l}\text { Can continue cultivation if owner did not pay } \\
\text { back qidi money. }\end{array}$ \\
\hline 1833 & & & $\begin{array}{l}\text { Different from the other tenancy deeds, this land } \\
\text { was not developed, and the land owner allowed } \\
\text { the tenant 5 years to reclaim the land. After 5 } \\
\text { years, the land owner would pay the tenant 12 } \\
\text { dollars to take back the land. If he did not have } \\
\text { the money, the parties split the rental income } \\
\text { from the actual cultivator in 40\% (aborigine) and } \\
\text { 60\% (Han) shares. }\end{array}$ \\
\hline 1843 & 140 dollars & 0.2 shi & 10 years & $\begin{array}{l}\text { Can continue cultivation if owner did not pay } \\
\text { back qidi money. }\end{array}$ \\
\hline 1851 & 7 dollars & 0.3 shi & Not specified & $\begin{array}{l}\text { If the aborigine had the money to redeem he } \\
\text { should give advanced notice. }\end{array}$ \\
\hline 1854 & 10 dollars & 0.1 shi & 7 years & $\begin{array}{l}\text { Can continue cultivation if owner did not pay } \\
\text { back qidi money. }\end{array}$ \\
\hline 1883 & 126 dollars & 22 shi & 10 years & $\begin{array}{l}\text { If rent in arrears, land owner could terminate the } \\
\text { tenancy; right of renewal }\end{array}$ \\
\hline 1890 & 8 dollars & 4 dollars & 15 years & $\begin{array}{l}\text { Parties to return land and money respectively } \\
\text { when term due }\end{array}$ \\
\hline
\end{tabular}

Of the 12 deeds, the 1833 one was a different arrangement involving land reclamation and cultivation. The 1883 deed gave the landlord rights to terminate the tenancy in case of rent arrears, and together with the 1890 deed there was no provision for continuing cultivation if the landlord could not pay back the qidi money. These three transactions might be genuine tenancy arrangements. Two of them occurred after the change of policy in 1875, by which time control on sale of aboriginal land had relaxed. The other nine deeds were materially similar to dian - the land was given to the "tenants" to manage or cultivate for a period of time in return for a sum of money, and the money owner could continue possessing the land if the landlord could not pay back. In fact the term "redeem" ( $s h u$ 贖) 
was used in seven of the nine deeds. The sum of qidi money was usually tens or hundreds of times of the annual rent - in the 1843 case 700 times. The subsequent borrowing of money from the "tenant" in the 1812 deed was in essence a price top up in dian transactions (tiandian 添典).The existence of rent did not necessarily mean the true nature of transaction was lease, since in some outright sales the parties also agreed on an annuity. Furthermore, in most of the above cases the rent was a token, usually a friction of one shi. In the 1827 deed there was no rent at all.

The deeds show the flexible arrangements in the Chinese customary practice to obtain land rights or credits, which blurred the distinction between different land transactions such as pledge and tenancy. The fact that disputes between aborigines and settlers often broke out about whether certain transactions were $p u$ or $\operatorname{dian}^{123}$ showed that the distinction between dian and $p u$ was elusive. Since $p u$ could mean dian, and dian could mean sale, quite often the aborigines lost their land even through making periodic tenancy agreements, in addition to granting land in large rent.

\section{Government Efforts}

Thus, whether $z u, p u$, dian, or mài was used, any one word could represent temporary lease or permanent alienation of land. What was important was the content of the agreement, rather than the term used. Furthermore, different forms of alienation of property sat along a spectrum, and their distinctions were a matter of degree - how many rights were given up, rather than a matter of kind. The government was aware of this. The Grand Councillor Fukangan succinctly summarised the situation in 1788 (Qianlong 53) in a memorial to the Emperor, "settlers rented (diàn 佃) land from acculturated and non-acculturated aborigines for cultivation. If the price is low, it is called zupu; if the price is higher, it is called dianmài". ${ }^{124}$ The distinction of high or low price was vague, and it follows that there was no clear distinction between zири and dianmài. This provided an opportunity for settlers and aborigines to evade the law.

123 See 167-169.

${ }^{124}$ Dazu diaocha, above n 7, at 1027, “價輕者謂之贌租，價值稍重者謂之典䝴”. 
It appears that the government only perceived, or was concerned enough to address, the consequence later. This was when the aboriginal colonies (fantun) fell into Han hands. Regulations stipulated that the "upkeep land" was to be cultivated by the aboriginal warriors only, and prescribed consequences for cases of aborigines' dianmài the land ${ }^{125}$ The regulation was ambiguous in that, on the one hand it stipulated cultivation by the aborigines only; on the other hand it only forbade dian and sale but did not forbid lease. Within a few years, aborigines started to lease the land to settlers in large rent, sometimes even with the local officials' approval. ${ }^{126}$

Further, a decree issued by the Taiwan Circuit Intendant and published by the Sub-Prefect for Aboriginal Affairs Northern Circuit in 1818 (Jiaqing 23) found that the aborigines dian their land to settlers, but to evade the regulation, the deeds were given as deeds of $p u .^{127}$ The Circuit Intendant ordered redemption of land by aborigines in the cases of sale and pledge, and return of land in the cases of $p u$. This was to rectify the problem, and further efforts were made to control loans between settlers and aborigines. ${ }^{128}$ However no mechanism was devised to prevent further pledge or sale of aboriginal land in the name of lease or tenancy. In 1838 (Daoguang 18) the government investigated the situation of the "upkeep land" again. Officials found that the transactions were lease in large rent (geiken 給墾), and not pledge or sale. The Finance Commissioner of Fujian Province argued that, since the law only expressly forbade pledge and sale, the parties were not guilty of violating the law. ${ }^{129}$ Thus the matter was not addressed.

The government also tried to address the moneylending issue. In 1817 (Jiaqing 22) the Fujian Governor looked into the matter and forbade Han settlers from charging interest in dian and tai, required redemption within one year, and imposed a penalty on those who

\footnotetext{
125 Taiwan shili, above ch 2 n 64, at 43.

${ }^{126}$ For example, see a land deed of 1794 (Qianlong 59), in Dazu diaocha, above n 7, at 799.

127 At 771-773.

128 Ibid.

${ }^{129}$ Tai'an jiaji, above n 43, at 68 .
} 
refused the aborigines' redemption requests. ${ }^{130}$ As always, the administrative order could not adequately deal with the flexible private arrangements.

Therefore the government rarely intervened in private land transactions. When the government did intervene, it did not deal with the root issue of the lack of clarity between the various forms of land transactions.

\section{Property Law Regime and Aboriginal Land Tenure}

This chapter has documented the forms of land transactions between aborigines and settlers. A close analysis on the land reclamation permits and land registration reveals that these requirements were mainly for administrative purposes, and had very little consequence on property. In contrast, $z u, p u$, dian and sale were flexible and robust forms of land transactions which had determinative consequences on property rights.

It has been demonstrated that, from periodic tenancy to sale of land was a continuum transferring ever greater rights in property, often with no clear-cut distinctions. Because of the laws against pledge and sale, lease in large rent and periodic tenancy were often used by Han settlers to obtain aboriginal land. Throughout the whole period of the Qing rule, unreclaimed aboriginal land was granted to settlers in large rent by aboriginal villages as a collective, by fan yehu as the representatives of the villages, and by individual aborigines. ${ }^{131}$ Once the land was granted in large rent, the aborigines in effect lost the land ownership and only retained rent collection rights. Periodic tenancies were also used, from the early Jiaqing reign on and mainly for reclaimed land, to evade the law against pledge and sale. After the substantive land rights were lost, in many cases the aborigines sold or pledged rent collection rights to settlers, presumably because it was not "sale of land".

The Chinese customary practice and concepts of land ownership changed aboriginal land tenure in a gradual but dynamic process. The government played very little part in the private land practice. The Qing legal system, following the Chinese tradition, did not

\footnotetext{
${ }^{130}$ Dazu diaocha, above n 7, at 771-774.

131 The deeds in ibid, ch 3.2 (by villages), 3.3 (by fan yehu) and 3.4 (by individuals), dated from the early Yongzheng period to the end of the Qing rule.
} 
concern itself with personal or property law matters unless they were related to social order and security. Property matters were left for customary practice to regulate. Under this system, the Qing government did not interfere with the aborigines' customs, which helped to preserve aboriginal customary land tenure. By the same token, the Qing government did not interfere with the Chinese customary practice which was brought to Taiwan by the settlers. The settlers' land tenure eventually became the dominant practice in Taiwan. It eluded the government's regulations against alienation of aboriginal land, and changed aboriginal customary tenure.

When the government intervened, it was through administrative and criminal law means, but the intervention usually came when the practice had become prevalent and difficult to control. In the late Kangxi years, the Zhuluo magistrate envisaged the emergence of split ownership. In the early Yongzheng years officials recommended limiting the areas of land granted in one permit, so as to eliminate the yezhu class, but the government preferred not to interfere. ${ }^{132}$ When the problem became widespread and serious, in 1764 and 1765 (Qianlong 29 and 30), the Fujian provincial government made regulations to "forbid and abolish” (jinge 禁革) split ownership. ${ }^{133}$ Such an administrative order could not control the long-standing and deep-rooted practice among the people, and the practice continued to be prevalent in Taiwan.

Customary land practice existed independently of the formal law, and the government respected it in most cases, but was powerless to change it in others. The government's fault concerning aboriginal land was in its unwillingness or inability to intervene in or regulate the customary practice.

The aborigines were impoverished, and they needed money to sustain themselves, to pay village taxes and for other public expenditure. ${ }^{134}$ The land was their only asset. Faced with the powerful commercial economy that the Han brought, they voluntarily or involuntarily

\footnotetext{
${ }^{132}$ See the Taiwan Prefect Shen Qiyuan's recommendation in Ming Qing dang'an, above n 71, vol 13, at 224-229.

${ }^{133}$ Fujian shengli, above n 50, at 445-447.

${ }^{134}$ See Shih “Qingdai Taiwan 'fanli bu'an gengzuo' de yuanyou”, above ch $3 \mathrm{n}$ 1, in general.
} 
participated in land transactions, and lost their land. However this did not mean that they always passively accepted what Han settlers imposed on them. The next chapter explores aboriginal reactions to the spreading Han settlement and the dominant Han culture, and the result of the interactions among settlers, aborigines and the government. 


\section{Chapter 5}

\section{Aboriginal Reactions and Further Government Responses}

The Qing government, the Chinese settlers and the aborigines were the three major actors in the Chinese settlement of Taiwan. ${ }^{1}$ As demonstrated in earlier chapters, in general the government endeavoured to protect aboriginal land rights for the purposes of social stability and security of the reign, but the government and officials subtly changed the attitude towards aboriginal land at the turn of the $19^{\text {th }}$ century. Chinese settlers influenced and transformed aboriginal land tenure through private land transactions. Land transactions were not always the result of fair dealing, and aborigines were often in a disadvantaged position because of their lack of commercial sophistication and financial power. Settlers also employed various other means to obtain aboriginal land, including forceful occupation, encroachment, and "peaceful means" such as marrying into an aboriginal family or building other close personal relationships with aborigines. ${ }^{2}$ The aborigines, apart from serving as the government's reliable assistants in suppressing settler uprising and guarding the boundary lines, interacted with the government and settlers regarding land settlements in Taiwan.

This chapter examines the Taiwanese aborigines' reactions against land settlement and encroachment by Han settlers. The government's actions in the process are also discussed. Part I discusses aboriginal resistance against Han settlement, which was the aborigines' first choice, especially at the early stages of contact when they first felt threatened by settlers. Early stages of contact do not necessarily mean the early annexation years, because new contacts were made as settlements advanced to new areas over time. Resistance was often manifested as armed conflicts and violent clashes, but in some cases it took peaceful forms. This Part also discusses the government's attitudes and actions concerning the aborigines' armed resistance, and the combined consequences of actions from the aborigines, settlers and the government. Part II examines the aborigines' appeal to the

\footnotetext{
${ }^{1}$ Shepherd Statecarft and Political Economy on the Taiwan Frontier, above "Introduction" n 35, at 7 and 243.

${ }^{2}$ Wen Taiwan fanzheng zhi, above ch 3 n 33, at 300-301; Huang Fu-San "Qingdai Taiwan yimin de gengdi qude wenti jiqi dui tuzhu de yingxiang" [The methods of acquiring land by migrants in Qing Taiwan and the effects on the aborigines] (1981) 11 Shih-huo 72, at 72-75.
} 
government for help when they felt their interests were jeopardised. The disputes brought before the government show changing focuses, and to some extent reveal the tenurial and societal changes of the aboriginal communities over the centuries. Part III discusses the aborigines' adaptation to the agricultural and commercial environment which followed Han settlement. In particular, this Part uses the examples of "cession of land for water" (gedi huanshui 割地換水) transactions and the establishment of new settlements by the plains aborigines to demonstrate the aborigines' adaptation to their new environment and their transformation to be more like Han settlers - a kind of cultural sinicisation. Part IV looks into the first Taiwan Governor Liu Mingchuan's land tax reform, which was the last Qing government action that affected aboriginal land tenure. This chapter depicts the societal and tenurial changes of the aboriginal communities, and demonstrates that the aborigines were the least informed and most disadvantaged actors in the aboriginal land tenure changes during the Qing period. It argues that the aborigines resisted Han settlement on the one hand, and accepted and adapted to Han practice on the other; and the government protected aboriginal land against Han encroachment on the one hand, and disregarded aboriginal rights on the other when imperial interests required otherwise. These all worked together for the breakdown of the aboriginal communities and land tenure in a gradual but irreversible manner.

\section{Resistance}

The aborigines had protested against Han use of their land since the era of Dutch colonisation. They killed those Chinese who entered their land to hunt deer, even though the Dutch authorities had licensed the Chinese to do so. ${ }^{3}$ During the Zheng period, violent resistance broke out in localities where the Zhengs attempted to have land reclaimed. ${ }^{4}$ During the Qing period, as land reclamation advanced, the aborigines continued to resist. Resistance mainly took the format of violent conflicts and attacks on settlers, although in some cases more peaceful means of resistance have been recorded. Armed conflicts threatened the social order, and the government's maintenance of aboriginal boundaries

\footnotetext{
${ }^{3}$ Andrade How Taiwan Became Chinese, above ch 1 n 80, at 140.

${ }^{4}$ Wen, above $n$ 2, at 55-56. Also see discussed in above ch 1 Part III.
} 
was strengthened by the establishment of ai (险 guard posts), which were eventually used by settlers to push aboriginal boundaries towards the aboriginal territories and to advance land reclamation.

\section{A Aboriginal Resistance}

\section{Armed resistance}

At the beginning of the annexation, settlers were few and land reclamation mainly took the form of recovering land that had already been reclaimed but left to waste as a result of the change of dynasties. No direct conflict was recorded for this period, even though the Chinese oppression of aborigines certainly occurred.

In 1697 (Kangxi 36), the Chinese traveller Yu Yonghe travelled along the western coast of Taiwan. In his work A Small Sea Travelogue, he praised the innocence and good nature of the aborigines. ${ }^{5} \mathrm{Yu}$ noted that the Chinese merchants and interpreters oppressed the aborigines, took advantage of them, and took aboriginal women as wives and concubines, which the aborigines apparently "did not especially resent". ${ }^{6}$ However, armed conflicts with Han settlers occurred in the last few years of the Kangxi reign. ${ }^{7}$ By the Yongzheng reign, incidents of aborigines attacking settlers had become frequent. The government recognised that these attacks were a result of settlers encroaching on aboriginal territories to reclaim land or acquire resources. ${ }^{8}$

In total, 145 armed attacks by aborigines on settlers throughout the Qing period have been recorded. ${ }^{9}$ There was a clear correlation between aboriginal attacks on settlers and the spread of Han settlement.

\footnotetext{
${ }^{5}$ See Yu Bihai jiyou, above ch 1 n 24, at 33.

${ }^{6}$ At 37, “不甚怨之”.

7 Two cases in the late Kangxi years were recorded. See Huang Huan-yao "Qingji Taiwan fanhuan shijian zhi benzhi tantao" [A discussion on the nature of aboriginal attacks in Qing Taiwan] (1987) 79 Taipei Wen Hsien 129, at 133, Table 1.

${ }^{8}$ For example, see memorials and the Emperor's rescripts in Yongzheng zhupi zouzhe [Memorials with rescripts of the Yongzheng Emperor] (TWWX 300), at 4, 36-37, 41 and 47 concerning several incidents in the years of Yongzheng 3, 4, 5 and 7.

${ }^{9}$ Huang, above n 7, Table 1.
} 
Among the 145 recorded incidents, 71 occurred before the shift of policy in 1874, including 25 attacks on land reclaimers, 11 attacks on settlers who crossed the aboriginal boundaries to cut timber, and 18 cases of attacking villages to kill or wound settlers, burn houses and loot property. ${ }^{10}$ In a number of cases settlers were forced to abandon land reclamation. ${ }^{11}$ The period that experienced the most frequent attacks was the Yongzheng era, which was the period when land reclamation advanced rapidly. The area that had the most incidents of attacks was Danshui Sub-prefecture, which was the frontier of land reclamation. ${ }^{12}$

In total 74 cases occurred after the government started to "open the mountains" in 1874; most of these were directed at the soldiers and some at reclaimers and timber cutters. ${ }^{13}$ In particular, 1874-1875 and 1886-1887 saw a lot more attacks, ${ }^{14}$ as the "opening the mountains" campaigns were promoted vigorously during these two periods. In addition to the 74 incidents, 31 direct confrontations with government troops, coordinated among a number of villages, were recorded after $1874 .{ }^{15}$ The frequency and scale of violence were the result of the forceful opening of the aboriginal territory.

The main locations of aboriginal attacks on settlers during the Kangxi reign were the earliest settled area of Taiwan County. During the Yongzheng era Fengshan, Zhuluo and the newly established Zhanghua County saw most attacks. The Danshui Sub-prefecture became the area of frequent attacks during the Qianlong era, followed by the newly incorporated Gamalan during the Jiaqing period. After 1874 the attacks concentrated at the "back of the mountains" (houshan 後山) and the newly established Hengchun County at the southern end of Taiwan. ${ }^{16}$ Incidents of aboriginal attacks clearly followed the spread of Han settlement.

The aborigines' resistance might have slowed Han advancement, but could not stop it. One way or another, sooner or later, Han settlements penetrated the aboriginal zone and became

\footnotetext{
${ }^{10}$ At 145 .

11 Ibid, Table 1.

12 At 146-147.

13 At 146.

${ }^{14}$ Ibid, Figure 4.

15 Table 3.

16 Table 1.
} 
established. One well-documented example was the reclamation of Gamalan. The Gamalan aborigines resisted reclamation attempts led by a Han settler Lin Hansheng in 1768 (Qianlong 33) and killed Lin. ${ }^{17}$ The leader of the successful Han settlement in Gamalan, Wu Sha, was also defeated by the aborigines in the first attempt to reclaim Gamalan in the late Qianlong years, resulting in the death of Wu's brother. ${ }^{18}$ In 1796 (Jiaqing 1), Wu built the first stronghold (touwei 頭圍) to protect reclamation, and battles occurred on a daily basis with heavy casualties on both sides. ${ }^{19} \mathrm{Wu}$ managed to befriend the aborigines through providing medication to the aborigines when an epidemic struck, but subsequent reclamation of Gamalan still had to be protected by strongholds around occupied areas, which gradually expanded and advanced. Similarly, in 1815 (Jiaqing 20) some Han settlers entered inner Shuishalian to reclaim land. The first three villages that they encountered were small and could not resist the settlers, but the Puli village armed themselves to resist against Han encroachment for over a month, before the settlers tricked them into an unprepared attack and slaughtered the aborigines. ${ }^{20}$

Therefore, the advancement of Han settlement was often met with violent resistance from the aborigines, before the aborigines were overpowered and gave in.

\section{Peaceful resistance}

While there is abundant evidence of conflict, resistance also took less violent forms, ${ }^{21}$ typically by resisting settlers' attempts to gain title to land.

Some aboriginal leaders were well aware of the risk of Han settlement since the late Kangxi years. In one example, some Han settlers proposed to purchase land from the Shalu village, located in the central western plains. The village head told the villagers that, all that their ancestors had left them was that piece of land, which provided for their livelihood and tax payments. If they sold any part to the Han, the Han would occupy and steal the rest, and

\footnotetext{
${ }^{17}$ See Yao Dongcha jilüe, above ch 2 n 81, at 70.

${ }^{18}$ Ke Gamalan zhilüe, above ch 1 n 134, at 89.

${ }^{19}$ Yao above n 17, at 70, “與番日鬥, 彼此殺傷甚眾”.

${ }^{20}$ At 34.

21 This is also a characteristic of many frontier societies, such as in Australia, Argentina and the United States. See a discussion in Boast Buying the Land, Selling the Land, above "Introduction" n 8, at 16.
} 
very soon the whole village would lose their property. The village head told the villagers to resist the proposal, which he could not do in person as he had friendly relationships with the settlers. ${ }^{22}$ This incident illustrates that the aborigines were well aware of the importance of land, of the methods used by settlers to acquire it, and of the consequences of landselling. This same incident also shows the complex relationship between settlers and aborigines in some cases, where they could be friendly towards each other, but pursue competing strategies at the same time.

It is not clear how many aborigines were as insightful as the head of the Shalu village, but as aboriginal land increasingly became lost to Han settlers, more aborigines became resistant to Han expansion. In 1823 (Daoguang 3), 14 plains aboriginal villages that moved to the Puli basin in inner Shuishalian made a covenant to exclude settlers from their land affairs. ${ }^{23}$ The covenant recounted that after Taiwan entered the Qing realm, the rights to use and manage the grassland remained with the aborigines (gui fan zhangguan 歸番掌管). Further, the government had rewarded the aborigines with the establishment of aboriginal colonies in 1788 (Qianlong 53) and gave them rights to reclaim wasteland beyond the aboriginal boundaries. However their Han tenants, seeing that the aborigines were ignorant, had cheated them or used loans as bait, and the aborigines lost almost all of their land through Han purchase (maishu daijin 買贖殆盡). The same document records that the villagers had now found a piece of unreclaimed land, and that they would encourage each other to work hard on the land. They promised each other not to allow Han settlers to reclaim the land, nor employ settlers to work on the land or manage their affairs. Those who breached the covenant would be expelled from the land. The villages were mostly from the central western plains, and they had a clear understanding of the course of land loss and of actions needed. These aborigines flourished in their new settlement. ${ }^{24}$

Actions were also taken to prevent aborigines from pledging or selling their large rent collection rights after the land was granted in large rent to Han settlers. In 1831 (Daoguang

\footnotetext{
${ }^{22}$ Huang Taihai shichalu, above ch 1 n 25, at 128-129.

${ }^{23}$ See the covenant in Wen, above $n$ 2, at 317-318.

${ }^{24}$ As will be further discussed in Part III.
} 
11) the aborigines of Zhonggang village, when signing a covenant about the division of village rent, vowed to punish those who pledged or sold their share of rent. ${ }^{25}$ Continuous complaints to the authorities that settlers dwelt among the aborigines and coveted their land and property ${ }^{26}$ also evidenced that the aborigines were wary of Han settlers mingling with aborigines to possibly take advantage of them and cheat them out of their lands.

There is little recorded evidence of aborigines forming alliances in their resistance of Han settlement. There are two probable reasons for this. As discussed in Chapter 1, the aborigines were ethnically and linguistically diverse and were rarely united. Furthermore, Han settlement did not occur in all areas at the same time. Rather, it progressed from one area to another, meaning that aborigines were affected by settlement at different times. The settlement pattern and the lack of coordinated resistance resulted in the eventual encroachment of aboriginal land.

\section{B Government Attitudes and Actions}

The government had no issue with the aborigines' peaceful resistance. Quite often officials themselves lamented the cunning of settlers and innocence of the aborigines, and condemned the tricks played by the former on the latter. However, officials tended not to intervene in peaceful interactions between settlers and aborigines. The story about Shalu village's refusal to sell land was recorded by the Taiwan Censor as a point of interest, and no view was expressed one way or the other. This reluctance to intervene in private affairs evidences the principle held by the government and the culture among officials at a practical level.

Armed resistance, however, was another matter, as this obviously disturbed social order. In such cases, the government's attitude leaned towards the aborigines, but the solutions, whether intended or not, often facilitated settler advance. This was particularly the case from the early 1800 s.

\footnotetext{
${ }^{25}$ Dazu diaocha, above ch 3 n 22, at 667-670.

${ }^{26}$ As will be discussed in Part II.
} 
The government was well aware of aborigine-settler conflicts and the reasons behind them, and was often sympathetic towards the aborigines. In 1725 (Yongzheng 3), the Fujian Governor reported that during that year three or four cases of mountain aborigines killing settlers had occurred. The reason was that settlers either had encroached upon the aborigines' territory to reclaim land, or had damaged the aborigines' forests by cutting trees. ${ }^{27}$ The Yongzheng Emperor, even though his reign has been seen as a period of expansion and colonisation in Taiwan, disapproved of retaliation against the mountain aborigines. $^{28}$ The government generally distinguished between cases where settlers were killed in aboriginal territories and where aborigines entered settled areas to kill. ${ }^{29}$ Encroaching settlers were seen as “villains” (jianmin 奸民), and were punished for crossing the aboriginal boundaries and causing social instability. ${ }^{30}$ Therefore the primary blame and restraint were placed on settlers.

The government's typical approach prior to 1874 was to strengthen border control. ${ }^{31}$ Eventually border control changed from simply marking boundaries by stelae with inscribed warnings, to a system of border posts ( $a i$ 险) and guards.

Border guards were first employed by land reclaimers during the Qianlong reign to protect the reclaimers from mountain aborigines' attacks at a time when land reclamation spread to the foothills near aboriginal boundaries. ${ }^{32}$ Reclaimers either set aside some land as a reward to the guards who could lease the land for rent, or paid the guards a portion of the harvest as their wages. In both cases what the guards received was called "guard-post rent" (aizu 险租).

During the late Qianlong reign, illicitly reclaimed land beyond aboriginal boundaries was investigated, confiscated and turned into aboriginal "company land" to support members

\footnotetext{
${ }^{27}$ Yongzheng zhupi zouzhe, above n 8, at 3-4.

${ }^{28}$ See the Emperor's rescripts in ibid, at 4, 37and 39.

${ }^{29}$ At 72 and 142 .

${ }^{30}$ For example, ibid, at 47-48.

${ }^{31}$ Huang Huan-yao "Qingling shiqi Taiwan de fanhuan fangzhi" [The prevention and management of aboriginal attacks in Qing Taiwan] (1988) 32/33 Gaoshi wenxian 21, at 21-29.

${ }^{32}$ For the development and functions of ai, see Tai Qingdai Taiwan zhi xiangzhi, above ch 3 n 84, Part 8; Inō Taiwan wenhua zhi, above "Introduction" n 32, vol 3, Part 14, ch 5.
} 
of the aboriginal companies. Thus the post guards lost the land or rental income from carrying out the guard duty. Because the guards were mostly acculturated aborigines who were good fighters, and also because the boundaries still needed to be guarded, the government decided to retain the border guards and pay their wages from the rental of the "company land". Thus the government became involved in the guard posts system. ${ }^{33}$

During the Jiaqing and Daoguang reigns, the western plains were well developed and settlers struggled to find new land for reclamation. As settlers tried to reclaim land near the mountain aboriginal territories, guard posts became prevalent as a means to protect reclaimers from aboriginal attacks. As such they essentially maintained security along the borders. ${ }^{34}$ Because of increasing financial pressure as sell as increasing internal and external crises, the government was only too happy to let settlers organise the guarding of borders. Hence a system was established where head guards (aishou 险首) were nominated by the settler community and appointed by the government. ${ }^{35}$ Through the government appointment the private guard post system gained an official or semi-official status and authority. The government thus indirectly supported Han reclaimers' intrusion into aboriginal territories.

This coincided with relaxed protection of aborigines' rights since the late Qianlong and early Jiaqing reigns, and the government allowed or even initiated for settler reclamation of border land in return for policing the boundaries. For example, during the early Daoguang years, in responding to frequent harassment by mountain aborigines, the Danshui Sub-prefecture established a guard post in Shisuilun 石碎崙, and employed 40 guards. The wages were over 1,500 dollars per year, ${ }^{36}$ and the local government struggled to pay the money. ${ }^{37}$ Eventually the local government encouraged settlers to establish the Jin-Guang-Fu 金廣福 guards system, which built 40 guard posts, employed over 200 guards, and supported reclamation of thousands of jia of land in 25 villages. ${ }^{38}$ Thus guard

\footnotetext{
33 Ibid.

34 Tai, ibid, at 537-538.

35 At 543.

36 The value of about $1,500 \mathrm{shi}$ of grain.

${ }^{37}$ See Chen Danshui tingzhi, above ch 2 n 115, at 50.

${ }^{38}$ Inō, above n 32, vol 3, at 446; Lian Taiwan tongshi, above ch $1 \mathrm{n} 92$, at 858.
} 
post organisations like Jin-Guang-Fu became a facility to protect advancement of land reclamation into the aboriginal territories. The government, especially during the Jiaqing and Daoguang reigns, knowingly allowed it to progress. The intention was to maintain border peace without using government resource, but the arrangement essentially gave the private organisations power to advance into the aboriginal territories.

After 1874, the government sent troops to subjugate the aborigines and forcefully required reclamation of aboriginal land, and ended restrictions on Han settlement. The government certainly did not hesitate to quash aboriginal resistance against government troops, but it did not necessarily support settlers in cases of settler-aborigine conflicts. When dealing with a case of aborigines killing Han settlers in 1884, the then Taiwan Circuit Intendant, Liu Ao, reasoned that "the aborigines do not kill without a good reason. It was all because the settlers attempted to encroach on their [aborigines'] land, and they [settlers] brought death onto themselves". ${ }^{39}$ In responding to a recommendation to send troops to punish the aborigines, the Intendant retorted that such an action meant that the government and settlers had united to rob aborigines of their land, which had never been the government policy, otherwise it would have been carried out and achieved long ago. ${ }^{40}$ Therefore although the government promoted settlement, this did not give the settlers a licence to violate aboriginal land rights. Officials remained of the view that settlers were responsible for aboriginal retaliation.

In summary, at first the aborigines resisted Han settlements when settlers encroached upon their living space and threatened their traditional life style. Their resistance, be it violent or peaceful, might have slowed down Han settlement, but could not prevent it. The government maintained a non-intervention stance if the aborigines' resistance was peaceful, and tried to prevent armed conflicts between settlers and aborigines. The government's attitude was probably harsher towards settlers than towards aborigines, but in reality, the government pursued its own goal of border security, and aboriginal land rights could be sacrificed for security purposes.

\footnotetext{
${ }^{39}$ Liu Xun Tai tuisilu, above ch 3 n 122, at 203.

${ }^{40}$ At 192.
} 


\section{Litigation}

The aborigines who surrendered to government authority had sought the government's protection in cases of disputes and infringed rights. This particularly occurred in Han settlement areas where settlers and aborigines had prior agreements about land use.

Direct sources about aboriginal involvement in litigation are scant, but from the available sources, it appears that although the aborigines brought cases to the authorities regarding substantive land rights, most cases related to rents - rent rates, and collection and distribution of rent. In some cases aboriginal villages protested against settlers' behaviour in general, seeking to exclude settlers from their community and eliminate opportunities of land transactions, loans and other personal contacts so as to protect their land.

\section{A Cases on Land Rights and Rent Rates}

From the early annexation years, aborigines brought disputes over land to the local authority. The 1721 Lower Danshui deed, quoted in Chapter 4, recounted transactions and proceedings regarding the Tonobot estate. In the first instance, the aboriginal village granted a piece of land to Han reclaimer He-Zhou-Wang for reclamation, but afterwards the aborigines brought a case before the county magistrate for the yezhu rights over the estate and won the magistrate's support. In another case of the late Kangxi reign, it was the Han yehu who petitioned the government for protection of rights. The plaintiff, a Han widow, claimed that she had $p u$ a piece of land from the aborigines, but the aborigines, incited by their village merchant, disturbed the settlement and prevented her from exercising management rights and collecting rent. The Taiwan Maritime Defence Subprefect (haifangfenfu 海防分府) issued a decree forbidding anyone to incite the aborigines, and asking the aborigines to let the plaintiff observe the terms of the contract. ${ }^{41}$

By the early Qianlong years, even the Emperor had become aware that "cases of settlers and aborigines suing each other [regarding land] have been emerging constantly". ${ }^{42}$ The Emperor noted that settlers often encroached on aboriginal land, and when disputes arose

\footnotetext{
${ }^{41}$ Dazu diaocha, above n 25, at 22-23.

42 “民番互控之案, 絡繹不休”. See Gaozong shilu, above ch 2 n 24, at 34.
} 
they sought military officers' protection through transferring the land to the officers ${ }^{43}$ this means the officers became the yezhu and large rent holders and the settlers became their "tenants". Accordingly the Emperor's decree forbade military officers from acquiring estates in Taiwan. ${ }^{44}$ The high volume of litigation shows that the aborigines did not hesitate to resort to the authority to resolve disputes and protect their land. The central government's resolution in this case also shows that government policies were responsive to aboriginal complaints. However the order given to military officers was a simplistic approach and did not address the problem of encroachment by settlers.

Existing records show that many land cases were related to rent issues. Many claims requested rent increase, and the grounds for bringing such claims varied. In the 1721 Lower Dunshui deed, over a decade after the government adjudicated the Tonobot estate to the aboriginal village, the village petitioned the authorities for an increase of rent because the village population had increased, and the rent was not sufficient to support the population. Even through the request lacked contractual or legal grounds, the magistrate supported the request, presumably on the basis of "paternal" authority.

In another case, the ground of the petition arose from changes to the law. A decree issued by the Taiwan Circuit Intendant, Zhang Ting, in 1768 (Qianlong 33) mentioned that the aborigines could continue to lease the land at the customary rate of eight shi per jia for wet land and four shi per jia for dry land, if they were unable to cultivate the land themselves. ${ }^{45}$ Subsequently the aboriginal Dajia and Dehua villages petitioned the government, seeking a rent increase. The villages had earlier granted land to Han settlers for reclamation at an agreed rent rate of six shi per jia once the land was developed into wetland. ${ }^{46}$ On the basis of the 1768 decree, the aborigines petitioned the Aboriginal Affairs Sub-prefect to increase the rent rate to eight shi per jia. ${ }^{47}$ The then Sub-prefect, Zhang Suoshou (1767-1770),

\footnotetext{
${ }^{43}$ Ibid, “有客民侵占番地，彼此爭競，遂投獻武員”. Here the blame was placed on the Hakkas (kemin 客 民), who were settlers from Guangdong province, as opposed to the more numerous migrants from Fujian. ${ }^{44}$ Ibid.

${ }^{45}$ See the decree in Sifa cankao, above ch 2 n 122, vol 1A, at 293-294. This decree was also discussed in above ch 3 Part IV A.

${ }^{46}$ Dazu diaocha, above n 25, at 648-649.

${ }^{47}$ Ibid.
} 
adjudicated for the aborigines and upheld their request. The Taiwan Circuit Intendant, Jiang Yunxun (1769-1771), overturned Zhang's decision on appeal and the rent rate reverted to six shi. The aborigines appealed, and the case was referred to the succeeding Circuit Intendant, Qi Chongge (1771-1774), who supported the aborigines' claim in 1772 (Qianlong 37).

Two points are worth noting in this case. The first is that the two decisions that supported the aborigines' claims relied solely on the 1768 decree to uphold eight shi per jia of rent. Intendant Qi noted that maintaining the rent rate of eight shi would ensure consistency across the board, and dismissed the settlers' claim of investment in the land, including the construction of irrigation systems, as a valid ground for maintaining a lower rent rate. ${ }^{48}$ The 1768 decree to fix rent rates in effect ratified the practice of leasing aboriginal land in the large rent model, and abandoned the earlier policy of forbidding lease of aboriginal land. This in effect relaxed the protection of aboriginal land rights. However, as demonstrated in the above case, the decree set a minimum large rent rate for aboriginesettler leases and served to protect the aborigines' income at the practical level, especially when the ban on large rent lease had been ignored.

The second point to note is the government's clear disapproval of court actions. Intendant Qi, despite ruling for the aborigines, believed the aborigines were incited by villains (shegun 社棍) and required investigation of the background of the court action. The aborigines were excused from any punishment because their anxiety about their grain rations was understandable, but the village scribe (sheji 社記) was punished for drafting the petition for the aborigines ${ }^{49}$ This demonstrates the difficulties the aborigines faced in bringing cases to the authorities. The Chinese legal tradition strove for "no litigation" (wusong 無訟) and generally disapproved of court action. ${ }^{50}$ This attitude of government and officials aggravated the difficulties that the aborigines already faced because of language issues. A poem by Gamalan Sub-prefect Ke Peiyuan (1835) described the

\footnotetext{
${ }^{48}$ At 649.

${ }^{49}$ Ibid.

${ }^{50}$ This is a generally recognised fact. For example, see Zhang Qingchao fazhishi, above "Introduction" n 30, at 628-630.
} 
miserable state of the plains aborigines, where they were robbed of their land by Han settlers, and had trouble making themselves understood when they petitioned the official, who ignored their petitions, and flogged and scolded them. ${ }^{51}$

Therefore, aborigines were able to petition the government for protection of their rights and they often won the support of government officials. However, litigation was a difficult process for aborigines, not only because of their disadvantaged situation, but also because of the authority's attitude of discouraging law suits, which was rooted in the Chinese legal tradition.

\section{$B$ Protest against Han Behaviour}

The increasing interaction between aborigines and settlers over land matters and the frequent aborigine-settler disputes led the government to establish two aboriginal affairs sub-prefect positions in 1766 (Qianlong 31), based in Zhanghua and Taiwan counties respectively. The aboriginal affairs sub-prefects had full responsibility for all aspects of aborigine-settler interactions, and one of their main functions was to adjudicate and to prevent settler-aborigine land disputes. The government's intention was to protect aboriginal land rights and prevent Han settlers and government agents from oppressing the aborigines. ${ }^{52}$ To this end, the government prescribed that the sub-prefects were to investigate cases where Han “villains” (jiangun haoqiang 奸棍豪强) purchased or accepted pledges of aboriginal land, and to drive out Han “villains” (tugun 徒棍) who married aboriginal women and dwelt in aboriginal villages, and so on. ${ }^{53}$ These became grounds for aborigines to bring cases against Han settlers.

Relying on this policy, aborigines complained to the government about settler behaviour in the late Qianlong and early Jiaqing reigns. Some well-known decrees of this period, purportedly to protect aboriginal land rights, were in fact a response to aboriginal protests and petitions. In 1788 (Qianlong 53), for example, the Interpreter of the Anli village, who

\footnotetext{
${ }^{51} \mathrm{Ke}$, above $\mathrm{n} 18$, at 191.

52 See the Fujian-Zhejiang Governor-General's memorial on establishing aboriginal affairs sub-prefect roles in Inō, above n 32, vol 1, at 163-164.

${ }^{53}$ Ibid. Also see the decree recorded in Dan Xin dang'an, above "Introduction" n 56, vol 17, at 189-190.
} 
was an aborigine, complained to the Aboriginal Affairs Sub-prefect that some Han settlers dwelt in their village, took advantage of the ignorance of the aborigines and had secretly $p u$ aboriginal land without permission of the Interpreter. ${ }^{54}$

A few years later, in 1800 (Jiaqing 5), another Anli Interpreter complained that Han settlers had robbed aborigines of their rental income through illegal lending, purposely buried their dead on aboriginal land, entered aborigines' territory to gather rattan and burn charcoal, seduced aboriginal women, and used alcohol and money to lure the aborigines into debt so that they could possess the aborigines' land. ${ }^{55}$

Similarly, in 1804 (Jiaqing 9), the Interpreter of the Zhuqian village complained that some Han settlers lent money to settlers, charged high interest, accepted pledges of land and refused the aborigines' redemption requests. Moreover they rented houses from the aborigines, seduced their women and eventually robbed aborigines of their house. ${ }^{56}$

It is likely that these incidents were not isolated, and that settlers carried out the same activities elsewhere in Taiwan, especially money lending. In 1817 (Jiaqing 22) matters became so serious that the Governor of Fujian Province intervened and set some rules concerning Han money lending and pledging and mortgaging land by aborigines. ${ }^{57}$

Settler attempts to take advantage of aborigines did not stop and aborigines continued to protest to the authorities where they could. In 1867 (Tongzhi 5), the lieutenant (waiwei 外 委) of one of the aboriginal companies complained that Han tenants either tried to wrestle the land rights out of the aborigines' hands or were not paying rent in full. ${ }^{58}$

These cases all appeared to be based on the government's guiding principle to reduce settler-aborigine interaction, and in particular to prevent settlers from cheating aborigines. The problem with this kind of cases is that they were general complaints and no respondent

\footnotetext{
${ }^{54}$ Dazu diaocha, above n 25, at 768-769.

55 At 769-770.

56 Sifa cankao, above n 45, vol 1A, at 296-297.

${ }^{57}$ See a notice published by the Aboriginal Affairs Sub-prefect in 1818 (Jiaqing 23), in Dazu diaocha, above n 25, at 771-774. See details discussed in above ch 4 Part IIIC.

58 At 814.
} 
was named in the complaints or called upon to answer the cases. The typical response of the local government was to issue a public notice to forbid Han settlers from doing the acts that the aborigines complained about. This was the uniform response in all the cases cited above. Because the public notices were in response to complaints and the publication was in limited areas, they usually did not achieve any significant result, shown by the fact that protests continued to be made.

\section{Rent Distribution}

Rent distribution was another focus of litigation, reflecting the societal changes in the aboriginal communities and a new form of conflict between aborigines and settlers.

As most aboriginal villages leased their land as the collective owner, usually the village interpreter or village head, who managed the village affairs, collected rents on behalf of the villages. They also appropriated the rent for various purposes, including paying village taxes, miscellaneous government fees and village expenditure; paying wages and allowances to those who had a role in the village affairs; and distributing grain rations to the villagers. Village heads and interpreters had existed long before the Qing annexation, but during the Qing period they became village office holders whose appointment was ratified by the government. They became the interface between the state and the village community. Because of issues of Han interpreters embezzling village rentals, in 1757 (Qianlong 22) the government started to replace Han interpreters with aborigine interpreters, as by this time aborigines were becoming competent for this role with increasing fluency in the Chinese language. ${ }^{59}$ At about the same time, fan yehu also became an office holder recognised by the government. ${ }^{60}$ Village heads, interpreters and fan yehu were recommended by the village, in particular by the educated, the elders or other aborigines who had roles in village affairs. The government checked the ability and integrity of the nominees, made the appointment and issued a seal of office. ${ }^{61}$ Despite the safeguards surrounding the appointments of these office holders, complaints about embezzlement of village rents by the office holders continued. Sometimes competitors for

\footnotetext{
59 Tai, above n 32, at 389.

${ }^{60}$ At 394. See above ch 4 Part II for more on fan yehu.

${ }^{61}$ At 373-374 and 386-396.
} 
appointment to a position brought cases against each other, as they fought for the power to receive and dispose of rents on behalf of the village. ${ }^{62}$

Existing records of individual cases of complaints came mostly from the Guangxu years, but it is known that by the early Daoguang years, cases about embezzlement of rents by interpreters, village heads or fan yehu had become "incessant". ${ }^{63}$ Village heads and fan yehu were aborigines, as were most, if not all, interpreters. Therefore most complaints about embezzlement of rentals were internal affairs in each aboriginal village, but still Han settlers were often involved. For example, in 1878 (Guangxu 4), aborigines of the Tunxiao village complained to the Aboriginal Affairs Sub-prefect that their Interpreter embezzled $950 s h i$ of their 1350 shi annual rent. ${ }^{64}$ The aborigines complained that it was a Han individual, Jiang, who conspired with an aborigine, Pan, in making Pan an Interpreter, and the rent was in fact received by Jiang. The case reached the Taipei Prefect, who removed Pan from the office, and required him to pay tax and village expenditure for that year, but did not require him to repay the residual amount to the village. The Prefect further stipulated that from the next year, the aborigines would divide the rent equally among them after deducting village taxes and expenditures. ${ }^{65}$ The Prefect also mentioned that in most cases the role of interpreter was assumed by aborigines who were manipulated or were in collusion with Han settlers, and that in his previous administration of central Taiwan he had ordered all interpreters to divide the village rents equally among the aborigines. ${ }^{66}$

This case illustrates some facets of aboriginal communities in general and property rights in particular. Firstly, even in the late period of the Qing rule, aborigines maintained separate identities and were administered separately through the preservation of aboriginal villages. Further, many aboriginal villages still had collective rental income after 200 years of Qing rule. Tunxiao was under the Qing administration by 1693 (Kangxi 32), being one of the

\footnotetext{
${ }^{62}$ For example, see cases in Dan Xin dang'an, above n 53, vol 13, topics on Shewu (village administration) and Shezu (village rent).

${ }^{63}$ As noted in a covenant between the Interpreter and villagers of Zhonggang village in 1831 (Daoguang 11), in Dazu diaocha, above n 25, at 667.

${ }^{64}$ See case notes in Dan Xin dang'an, above n 53, vol 13, file No 17202, at 109-130.

65 At 129.

66 Ibid.
} 
earliest villages that were subject to Qing authority. ${ }^{67}$ By the time of the rental complaints in 1878, the village had 39 households, and by 1888 (Guangxu 14) they still had an annual rental income of 1679 shi of grain. ${ }^{68}$ In 1888 the Danshui County recorded 17 aboriginal villages that were receiving rent at the village level, either by the interpreters and village heads (tongtu kouliangzu 通土口糧租, denoting unregistered land) or by fan yehu (denoting registered land). The total rent was 13,542.7 shi of grain. ${ }^{69}$ The Xinzhu County recorded 16 villages with total rent of $9,743.5$ shi of grain. ${ }^{70}$

It is likely that by the Daoguang reign, most, if not all, plains aboriginal villages had lost ownership of land, and large rent income was about the only income the aborigines had and the only connection, albeit a weak one, that they had with their land. Once there was no more land to be taken, Han settlers became involved in rent collection and distribution in most villages, as noted by the Taipei Prefect. The reason why Han settlers could become involved in village rental affairs was again related to money lending. As part of loan arrangements, and possibly to avoid the onerous tasks of official engagements and village affairs, aboriginal leaders let Han creditors take charge of village rents, including to collect rent, deduct interest from the rent, pay tax on behalf of the village, and distribute grain rations to the ordinary aborigines. ${ }^{71}$ Village heads and interpreters entrusted to the Han agents (baoban ren 包辦人) their seals of office, which were needed for rent collection. This became a widespread practice, and in the 33 villages in Xinzhu and Danshui Counties, only one did not have a Han agent. ${ }^{72}$

Ironically, a major cause of village loans was that aborigines were engaged in litigation, especially litigation with Han settlers over land rights and litigation among aborigines for competition over public offices in the village, such public offices being invested with the power to collect and distribute village rents. ${ }^{73}$ The aborigines could not afford the costs of

\footnotetext{
${ }^{67}$ See a list of annexed villages in Zhou Zhuluo xianzhi, above ch $1 \mathrm{n} \mathrm{124}$, at 31-32.

${ }^{68}$ Dan Xin dang 'an, above n 53, at 126 and 362.

${ }^{69}$ See the list of villages and rent in Dan Xin dang 'an, ibid, vol 13, at 299-316. This included the $40 \%$ of rent which was later ceded to small rent owners in the tax reform, to be discussed in Part IV.

70 At 354-372.

${ }^{71}$ Ibid.

72 At 398.

73 Tai, above n 32, at 398 and 432-433.
} 
litigation themselves and had to borrow from Han settlers. Therefore it became a vicious cycle - the aborigines litigated for land and rent, and as a result Han settlers had the opportunity to access village rents, which caused more litigation.

Ordinary aborigines were the ones who suffered, as they often could not receive their grain rations, which were their only livelihood. To solve the problem, some aboriginal villages chose to divide village rents and assign rent collection rights and obligations to individual households. For example, as early as in 1830 (Daoguang 11), the Interpreter of the Zhonggang village made a covenant with the villagers, where each person was appropriated five $s h i$ of grain per year, and each household was assigned specific tenants from whom they should collect the rent. ${ }^{74}$ This solution was adopted by officials, who ordered equal distribution of village rents, as the Taipei Prefect did. However the rent available for distribution were the residue once taxes and village expenditures had been deducted, amounts which occupied a substantial proportion of the total rental income. In the case of the Tunxiao village, although an annual rent of 1,350 shi of grain seemed a reasonable amount for 39 households, once taxes and village expenditures had been deducted, only about $700 s h i$ were left. ${ }^{75}$ The amount available for distribution further reduced during the tax reform, as will be discussed below. Furthermore, where the rent collection rights were individualised and the aborigines were assigned specific tenants, the collective aspect of village rent became obsolete, almost as though the land had been privatised.

Therefore, as interaction and land transactions with Han settlers increased, aborigines resorted to litigation for protection of their land rights. Similar to the aboriginal resistance of Han settlement, the Taiwanese aborigines' litigation against Han settlers over land was a process of the aborigines losing ground step by step. Aborigines at first litigated for land, but with increasing land transactions and possibly more elaborate land deeds which reduced ambiguity, the object of litigation soon became rent rates. The government tried to reduce Han-aborigine conflict through preventing Han-aborigine interaction, and aborigines complained that Han settlers tried to steal land from aborigines through mingling with

\footnotetext{
${ }^{74}$ Dazu diaocha, above n 25, at 667-670. The covenant distributes the rent according to ding J, which usually meant adult male, but it is likely that in this case it meant each person.

${ }^{75}$ Dan Xin dang'an, above n 53, vol 13, at 129.
} 
aborigines. The government in general upheld the aborigines' complaints, but the administrative orders made in response to complaints could not have far reaching effects. Eventually the land all fell into Han hands and the large rent rates fixed, and the problem became collection and distribution of village rent. Aborigines fought to protect their land rights and rent rights through litigation, but litigation added financial burden on the villages, which afforded Han creditors the opportunity to take control of aboriginal rent collection. This in turn caused more litigation. The solution that government officials and aborigines found was to individualise rent collection rights, so as to avoid corruption in and Han interference with the rent collection process. As a result the collective tenure broke down.

\section{Adaptation}

Yet another response was adaptation and acculturation. With increased exposure to Han culture, many Taiwanese aborigines gradually adapted to Han ways, including methods of land use, carrying out land transactions, and even in occupying and seizing land from less sophisticated aboriginal tribes. During the process some aborigines became influential landlords, others moved on to new settlements. Many became acculturated and lost distinctiveness as aborigines. The Taiwanese aborigines' acculturation reflects a common process throughout Chinese history - as ancient China expanded and Chinese culture and civilisation spread, formerly distinct ethnic groups became sinicised, adopted Chinese farming practices and imperceptibly merged into the Chinese world.

The adaptation and acculturation process of the Taiwanese aborigines began with the first contacts. By the time the Qing took over Taiwan, travellers found that the aborigines of the four villages close to the administrative centre of Taiwan Prefecture were "hardworking in husbandry" (qin jiase 勤稼穑) - denoting Chinese style farming - because of the Zheng government's education programme and the fact that they were close to the administration centre and Han settlement areas. ${ }^{76}$ The aborigines learned to contract with settlers and among themselves. As early as 1684 (Kangxi 22), the first year of annexation, an aborigine

\footnotetext{
${ }^{76} \mathrm{Yu}$, above n 5, at 17.
} 
of the Mattau village alienated a piece of land for 3,000 dollars. ${ }^{77}$ Before the mid-Jiaqing reign, many of the aborigine-settler contracts were bilingual, in Chinese and in aboriginal language - in particular the Sirayan language. ${ }^{78}$ These contracts indicate that the aborigines not only participated in land transactions, they were also aware of the necessity and importance of written contracts. By the Jiaqing years, aborigines carried out land transactions with one another, and made deeds in Chinese format even though both parties were aborigines. ${ }^{79}$

To illustrate the process of aboriginal acculturation, this Part focuses on aboriginal participation in land investment, using the "cession of land for water" as a principle example. This Part also addresses aboriginal mobility, involving searching for and moving to new settlements.

\section{A Participation in Land Investments}

The Anli villages formed a series of agreements to "cede land for water" with Han settlers during the Yongzheng years. The agreements demonstrate aboriginal participation in complicated commercial transactions, as well as the process by which they became competent in land dealings.

As the Chinese style of farming was mainly wet land rice planting, irrigation was very important for farmers. Most of the irrigation systems in Qing Taiwan were built by settlers, rather than by the government. As irrigation systems were complex and expensive projects, the investments usually came from land owners of a certain area jointly, or from wealthy investors who derived their return from charging a water usage fee known as "water rent". 80 Water rents were charged on various bases, such as the volume of water used or the area

\footnotetext{
${ }^{77}$ Li Xingang wenshu yanjiu, above ch 4 n 8, at 330-333. The deed was in Sirayan language only, and the Chinese translation is not coherent, but it is clear that it was about alienation of land.

78 The latest bilingual deed collected in Li, ibid, was made in 1818 (Jiaqing 23).

${ }^{79}$ For example, see deeds of pledge ranging from 1818 (Jiaqing 23) to 1882 (Guangxu 8) in Tung Yuan-Chao and Tseng Cheng-ming (eds) Gamalan Xilaya guwenshu [Historic documents of the aboriginal groups of Kavalan and Siraya] (NTU, Taipei, 1999) at 84-94 and 96-97.

${ }^{80}$ See Chen Zhe-san "Qingdai Nantou xianjing de shuizhen kaizao guanfu yu minjian suo banyan de jiaose" [The roles of the government and the society in opening water channels in Nantou County during the Qing Dynasty] (2007) 15 Fengjia renwen shehui xuebao 105-141, in particular, at 128.
} 
of land irrigated. ${ }^{81}$ A widely adopted rate was three or four shi of grain per jia of land, the equivalent of the large rent rate for dry land, or half of the large rent rate for wet land. ${ }^{82}$

It was against this background that the Anli villages signed agreements with Han yehu to exchange land for irrigation rights. The three available agreements are materially similar, and it is worth quoting the first one in full: ${ }^{83}$

The people who made this agreement [are] Pan Dunzai, the village head of Anli, Soushu, Wuniulan and Jiushe villages, and [a long list of individual aborigines' names]. Because [sic] the land within the territory of Dun et al is all dry land. [We had] planted crops, but without irrigation there has been no harvest every year and we are helpless. The aborigines assembled and discussed the matter. Through an intermediary we asked the Interpreter Zhang Dajing ${ }^{84}$ [to find] someone who could invest in labour and capital to build the irrigation system and share the water for land. The villages of Dun et al are willing to [give up] the land [location and boundaries]. This [land] is within the territory of the four villages, and did not encroach on other people's land. [The aborigines] are willing to use this [land] as a compensation for the labour and capital investment, and give it to the yezhu to recruit tenants for reclamation. In the future our descendants dare not say otherwise. [We] are willing to give up this dry land, and we humbly request Zhang Dajing to ask yehu Zhang Zhenwan to accept the task, [and] self [sic] invest in over 9,300 taels of silver to build the irrigation system and share the water with the aborigines. On this day the three parties agree that Zhang Zhenwan will build the irrigation system. The water is divided into 10 shares. Eight of them belong to Zhang Zhenwan to irrigate his own land, and two shares belong to the aborigines to water aboriginal farms. The land within the specified boundaries is given to Zhang Zhenwan for reclamation, to compensate for the investment in the irrigation building. [Zhang can] register the land for taxation, and have it as perpetual property. We guarantee that the aboriginal assembly is willing to cede this land for water, and Zhang Zhenwan is willing to invest silver to build the irrigation and share

\footnotetext{
${ }^{81}$ See Hui Tsun “Qingdai Taiwan zhi zufu” [Types of rents in Qing Taiwan] [1959] 10(2) Taiwan Wen Hsien 91, at 132-137.

${ }^{82} \mathrm{Ka}$ "Fanxiaozu de xingcheng yu yanbian", above ch $4 \mathrm{n} 115$, at 74.

${ }^{83}$ See the deed in Wen, above n 2, at 432-434. Appended as Appendix 2 to this thesis.

${ }^{84}$ Zhang was the villages' own Interpreter, but it was customary to say "through an intermediary" in a land transaction.
} 
water with the aborigines in exchange for land. [This is] a mutual agreement. In the future our descendants dare not request for price top-up or redemption. We guarantee that this land is our ancestral land, and does not involve other villages. [Further words of title guarantee]. Each year Zhang Zhenwan [will pay] 200 shi of grain, and Dun et al will transport it from [Zhang's] estate. [Concluding with usual contract formats]

It is noted this day, the aborigines of the four villages received 9,300 taels of silver specified in the agreement.

[List of names who signed the agreement]

In the tenth month of the first year of the Yongzheng Reign ${ }^{85}$

In this deed, Zhang Zhenwan was in fact the business name of the Interpreter Zhang Dajing. The total area of land is not specified, but it was a large parcel of land given that the land was across four villages. The deed was less than clear as to whether the 9,300 taels of silver was to be the aborigines' investment in the irrigation system or the total building cost of the system. Scholars usually assume that it was the total building cost, that is, the Han yehu Zhang's total investment. ${ }^{86}$ However at the end of the deed the aborigines acknowledged the receipt of 9,300 taels of silver. This suggested that the 9,300 taels of silver was the price of the land, which the aborigines had to invest in the irrigation system. Although other examples show that irrigation systems were very expensive to build, no original record exists to suggest the cost of building the system discussed here. Therefore this chapter tentatively adopts the common view that 9,300 taels was the total investment. The villages obtained $20 \%$ of the water rights, in addition to an annual payment of $200 \mathrm{shi}$ of grain.

In 1732, because the irrigation system that Zhang built was not sufficient to irrigate the areas required, Zhang together with another five yehu treated with the four Anli villages for the construction of another irrigation system. ${ }^{87}$ The six Han yehu invested 6,600 taels

\footnotetext{
${ }^{85}$ Most scholars accept that this deed was made in Yongzheng 1. Ka, above n 82, at 127, note 189, argues that the dating of the deed was incorrect and the correct date should be in 1733 (Yongzheng 11). However the 1732 deed, to be discussed below, referred to this project, therefore it could not have been made in 1733 . ${ }^{86}$ For example, Chen Qingdai Taiwan tuzhu diquan, above "Introduction" n 43, at 38.

${ }^{87}$ See the deed in Dazu diaocha, above n 25, at 23-26.
} 
of silver to build the system. ${ }^{88}$ The water rights were divided into 14 shares: the aboriginal villages had two shares and the six Han yehu each had two. In addition the aborigines received 600 shi of grain per year.

The next year, the interpreter Zhang Dajing found another yehu, Zhang Chengzu, to sign a third land-water exchange agreement with six Anli villages, being the original four plus another two. ${ }^{89}$ This time the villages gave up four parcels of land for $20 \%$ of water right of the new irrigation system, which Zhang would invest 8,300 taels to build. In addition the aborigines received an annuity of $520 \mathrm{shi}$ of grain. The annotation to the deed noted that Zhang paid an additional 3,200 taels in silver for rights to reclaim some residual land. The large amount of silver involved indicated that large areas of land were ceded.

Chart 18 Key Terms of Anli Village "Land for Water" Agreements

\begin{tabular}{|l|l|l|l|l|l|l|}
\hline & Aborigines & \multicolumn{1}{|c|}{ Settlers } & Land area & $\begin{array}{c}\text { Irrigation } \\
\text { investment } \\
\text { (taels) }\end{array}$ & $\begin{array}{c}\text { Water } \\
\text { rights } \\
\text { (Han:Abo) }\end{array}$ & $\begin{array}{c}\text { Annuity } \\
(\text { shi })\end{array}$ \\
\hline 1723 & 4 villages & Zhang Zhenwan & Not clear & 9,300 & $8: 2$ & 200 \\
\hline 1732 & 4 villages & $\begin{array}{l}\text { Zhang Zhenwan } \\
\text { and 5 others }\end{array}$ & Not clear & 6,600 & $6: 1$ & 600 \\
\hline 1733 & 6 villages & Zhang Chengzu & Not clear & 8,300 & $8: 2$ & 520 \\
\hline
\end{tabular}

Many records complained that settlers deprived aborigines of their land by cheating or unfair transactions, and these "land for water" agreements have usually been seen as a major way by which settlers deprived aborigines of their land. ${ }^{90}$ There are some good reasons for this view, since all three agreements were arranged by the villages' Interpreter Zhang Dajing, who officially represented the aborigines, while at the same time was the leading yehu and a party to the transactions. However, in fact the situation is more complex than might appear at first sight.

\footnotetext{
88 This deed only mentioned the investment of 6,600 taels of silver, but a subsequent deed, where one of the six yehu sold his share, was clear that the total investment was 6,600 taels. See the deed of sale in Sifa cankao, above n 45, vol 1C, at 117-118.

${ }^{89}$ Dazu diaocha, above $\mathrm{n} 25$, at 26-28.

${ }^{90}$ For example, Chen "Shijiu shiji chuqi tuzhu diquan wailiu wenti”, above ch 3 n 2 , at 34.
} 
Examining the agreements themselves, the aborigines were entitled to $20 \%$ of the water rights in the first and third agreements, and one-seventh in the second agreement. This means that the lands they gave up were deemed to be the corresponding percentage of the total investment. The aborigines thus changed from land owners to water right owners. To determine whether the transactions were unfair, one has to compare the value of the land rights ceded with the value of the water rights gained. This is almost impossible because the area of land is not clear, as is the designed capacity of the irrigation system. This itself may be an indication that the aborigines were not sophisticated enough to define the key terms of the contract. However looked at from another angle, the total investments of the Han settlers were specified. Hence in effect the ceded lands were quantified in monetary values, that is, $20 \%$ of the 9,300 taels, one-seventh of 6,600 taels and $20 \%$ of 8,300 taels respectively. These were in effect the selling prices of the land, and in addition the aborigines were paid an annuity for each parcel of land.

It is also important to note that no complaint against Zhang by the aborigines was recorded, and the Anli aborigines several times acknowledged Zhang's contribution of bringing irrigation to their villages, even after decades had passed, in the late Qianlong reign. ${ }^{91}$ Furthermore, irrigation building was a costly and time consuming project, sometimes taking two to three generations to complete. ${ }^{92}$ Here the risk of investment failure, additional funding and ongoing maintenance rested on the Han yehu. As a matter of fact, one of the six Han yehu in the second deed had to sell his share of water rights because he was not able to afford the maintenance. ${ }^{93}$ Another reason why the aborigines relied on Han settlers to build irrigation systems was that it was very technical and the aborigines were not able to handle projects of such scale and complexity. Investing in irrigation system carried high risks but gave high returns. ${ }^{94}$ Evaluating all the evidence, it appears that the aborigines were able to engage in meaningful negotiations with settlers on investment matters.

\footnotetext{
${ }^{91}$ See the aborigines' acknowledgements in Chen, above n 86, at 45. At 45-46 Chen indicates that Zhang might have been unfairly taking possession of the aborigines' land, but at the same time noting that none of the complaints against Han settlers was directed at Zhang.

92 At 39.

93 This is the deed of sale referred to in above $n 88$.

${ }^{94}$ Chen, above n 86 , at 39.
} 
Through these processes, the Anli aborigines became active players in land investments and competent landlords. Some lands were developed into wet lands, and the aborigines leased them on periodic tenancy, which meant that they collected higher rent than large rent, and also retained property rights over the lands.

As often was the case, usually one or two individuals adapted better than others because of their special position or ability. The head of the Anli village, Pan Dunzai and his family, became powerful and wealthy landlords. Following the example of Han yehu like Zhang, the Pan family's investment firm Dayouren reached land-water exchange deals with the aboriginal village of Old Anli (Anli jiushe 岸里舊社), but this time the village only obtained $10 \%$ of the water rights. ${ }^{95}$ Pan's family, in association with other investors, invested about 100,000 dollars over 70 years to transform the grassland of the Old Anli village into wetland. ${ }^{96}$ Most of Pan's land $-89 \%$ of wetland and $54 \%$ of dry land - was tenanted for periods fewer than three years. ${ }^{97}$ Thus improved infrastructure enhanced the aborigines' ability to retain ownership over their remaining land.

The Anli case was but one salient example. The Anli village group were not the only villages that carried out land for water transactions, and the Pan family was not the only aboriginal family that was successfully engaged in land transactions or farming activities. There were cases of aborigines purchasing large areas of land or redeeming land that was granted to tenants, involving thousands of dollars. ${ }^{98}$ Some aborigines reclaimed land of aboriginal villages and successfully developed grassland into wetland. ${ }^{99}$ Some became pledgees of land from their fellow aborigines. ${ }^{100}$ In 1880 (Guangxu 6), a Han yezhu reached a "land for water" agreement with an aborigine irrigation system owner, only this time it was the Han who gave up a parcel of land for a share of the water. ${ }^{101}$

\footnotetext{
${ }^{95} \mathrm{Ka}$, above n 82 , at 75-76.

${ }^{96}$ Chen, above n 86, at 90.

97 At 91.

98 See examples in Liu Dajia dongxishe guwenshu, above ch 4 n 9, at 139.

${ }^{99}$ For example, see a land deed of 1764 (Qianlong 29) in Dazu diaocha, above n 25, at 542-543.

${ }^{100}$ For example, a certain Pan A'xiang was the pledgee of several land deeds between 1861 (Xianfeng 11) to 1882 (Guangxu 8). See Tseng and Tung (eds), above n 79, at 88-93 and 96-97.

${ }^{101}$ See the deed in Dazu diaocha, above n 25, at 21.
} 
The success of the Pan family and other aborigines shows some of the aborigines' ability to participate in commercial activities, the process that they adapted to Han practice, and the positive effects on their land ownership once they became equal market players with Han settlers.

\section{B New Settlement}

Other aspects of aborigines' adaptation were shown in establishing new settlements. As the western plains were fully developed into farms, the acculturated aborigines organised several large scale migrations to the mountain areas. The migrations were caused by the reduction or loss of the aborigines' traditional living space due to Han settlement, ${ }^{102}$ but the process of migration to and settlement in new territories illustrated the aborigines' adaptation and acculturation to Han ways.

There were four major waves of aboriginal migration, each to a new direction. In 1804 (Jiaqing 9), over 1,000 aborigines from eight aboriginal villages in the central to northern parts of the western plains migrated to the newly developed Gamalan area. ${ }^{103}$ Subsequently aborigines from another two villages joined the movement, and they settled down in Gamalan.

The second wave was the migration of aborigines of five aboriginal groups, consisting of 32 villages, in central western plains to the Puli area of inner Shuishalian. ${ }^{104}$ This occurred because, after the Han encroachment of inner Shuishalian and subsequent government action in 1817 (Jiaqing 22), the Puli aborigines invited the plains aborigines to move in, to help resist Han encroachment. The aborigines arrived in successive groups from 1823 (Daoguang 3) and they thrived in Puli. Within 20 years, their population increased to over 2,000 people, while just over a score of Puli aborigines survived. ${ }^{105}$ By 1877 (Guangxu 3),

\footnotetext{
${ }^{102}$ Liang Chih-hui and Chung Yu-lan Taiwan yuanzhumin shi: Zhong Taiwan pingpu zuqun shi [History of Taiwan aborigines: the central Taiwan plains aboriginal groups] (Taiwansheng wenxian weiyuanhui, Nantou, 2001), at 125 .

103 Yao, above n 17, at 71. Also see further details in Liu Pingpu baishe guwenshu, above ch 4 n 9, at 7; Inō, above n 32, vol 3, at 495-496.

${ }^{104}$ Liu, ibid, at 7-8; Inō, ibid, at 493-494. The five aborigine groups are Pazeh, Babuza, Papora, Taokas and Hoanya.

${ }^{105}$ Ding Zhi Tai bigaolu, above ch 2 n 106, at 229. Also see Inō, ibid, at 494.
} 
the population of plains aborigines in Puli reached over $6,000 .{ }^{106}$ This shows that migration and resettlement was often a wise strategy.

The third wave was the migration of aborigines from five villages, of the Siraya and Makattao groups, in the south-western plains. The Siraya group was the first to be exposed to Han culture after the Dutch period, and their retreat to the mountain areas started during the Zheng period. The Makattao group started to retreat to the mountain areas in the midKangxi years. Aborigines from these two groups migrated to further south and to the east of Taiwan in 1829 (Daoguang 9). ${ }^{107}$

The fourth wave was the southward move of the Gamalan aborigines to the present day Hualian and Taidong in 1840 (Daoguang 20). ${ }^{108}$

These migrant plains aborigines adapted to the Han ways and resembled Han settlers in many ways. The main drive to migrate was to seek new land for agriculture. In the new settlements, they reclaimed land, conducted land transactions with the non-acculturated aborigines, encroached upon their land, and provoked conflicts. The aboriginal migrants of the first wave competed for land in Gamalan with Han settlers and held an advantage over the Han settlers, who were not strong enough to contest with the aborigines but eventually managed to appease them and break up their union. ${ }^{109}$ The aborigines that moved to Puli (the second wave) $p u$ land from the local aborigines. In one case they raised over 5,000 dollars to obtain most of the land in the Puli basin. ${ }^{110}$ In total they reclaimed about 2,000 jia of land. ${ }^{111}$

The aborigines from the south-western plains (the third wave) gave the southern aborigines alcohol, meat, tobacco and cloth in return for an agreement to reclaim their land. ${ }^{112}$ This was precisely the method by which the Han kenhu Chen-Lai-Zhang obtained the Taipei

\footnotetext{
${ }^{106}$ Fu Tai dang'an, above ch 2 n 119, at 15.

${ }^{107}$ Liu, above n 103, at 8-9; Inō, above n 32, at 494-495.

${ }^{108}$ Liu, ibid, at 8; Inō, ibid, at 495.

109 Yao, above n 17, at 71.

${ }^{110}$ Liu, above $n$ 103, at 8.

${ }^{111}$ Ding, above $\mathrm{n} 105$, at 229.

112 Inō, above n 32, at 494.
} 
basin for reclamation. After the agreement broke up, these plains aborigines moved further north into the eastern part of Taiwan. They reclaimed land, planted crops, kept buffalo and traded buffalo for land with the local aborigines, recruited their kinsmen from home to reclaim more land, and formed a sizeable settlement group. ${ }^{113}$ After the government opened up eastern Taiwan for settlement, usually a small number of Han settlers lived among the plains aborigines or the mountain aborigines, and the relationships between Han settlers and mountain aborigines were more harmonious than that between the plains aborigines and mountain aborigines. ${ }^{114}$ This shows that the plains aborigines were resented by the mountain aborigines, because the former had deprived the latter of their land, just as the plains aborigines resented Han settlers for the same reason.

In short, the plains aborigines adapted to the Han way, which was the main reason why they moved to new territories for land, and they used the same methods to obtain land from the non-acculturated aborigines as those that the Han settlers had used on them earlier. The pro-colonist Lan Dingyuan had envisaged a process of "acculturated aborigines being transformed to be like the Han settlers ( $\min$ 民), and the non-acculturated aborigines being transformed to acculturated ones". ${ }^{115}$ This vision was achieved over a century of interaction between Han settlers and the plains aborigines, and the plains aborigines' settlement in the mountain areas.

\section{Acculturation and the Government's Role}

The plains aborigines on the one hand acculturated to the Han culture, and on the other hand maintained a separate identity. That is to say, although in terms of culture they might have become similar to the Han, in organisation and politics they were still recognisable as aborigines. Government policies helped to preserve the aborigines' identity, until the 1886 (Guangxu 12) land tax reform.

\footnotetext{
113 Ibid.

${ }^{114}$ Lin "You yulin tuce kan Qingmo houshan de qingfu shiye yu diquan fenpei xingtai", above ch $1 \mathrm{n} 141$, at 150.

115 “生番化爲熟番，熟番化鴬人民”. See in Ding, above n 105, at 3.
} 
By the late Tongzhi years, most aborigines to the west of the mountains had been acculturated. The aboriginal population decreased, and their everyday life, such as housing, clothing, marriage and burial, mostly followed Han customs. ${ }^{116}$ By this time only about 20$30 \%$ of the aborigines could speak their mother tongues. ${ }^{117}$ This occurred through a long period of interaction with Han settlers, who formed the majority of the population and were culturally dominant.

The government had envisaged acculturation of the aborigines, but played little role in the realisation of it. When some aboriginal villages submitted themselves to the Kangxi government, the preferred treatment of the aborigines was to maintain status quo, and the Emperor specifically ordered officials to record the population as reported by the aborigines but not to take a separate census, so as to allow them to maintain their innocent nature. ${ }^{118}$ Later the government established schools for the aborigines, and organised teaching of farming to the aborigines. ${ }^{119}$ In 1758 (Qianlong 23) the government required male aborigines to shave their heads in the Manchu manner, ${ }^{120}$ but this was more than half a century after the Qing annexation, and many tribesmen had adopted the queue long before the government requirement. ${ }^{121}$ The government also provided Han style clothing to the aborigines, and several times bestowed family names or encouraged aborigines to adopt family names, since having family names represented one of the key Confucian values and officials thought it inappropriate that the Taiwanese aborigines lacked family names to carry on family traditions. ${ }^{122}$ These steps were about all that the government did to transform the aborigines.

After the change of policy in 1874, the government required that family names adopted by aborigines must bear certain features to distinguish them from Han surnames. ${ }^{123}$ The

\footnotetext{
116 Chen, above n 37 , at 306 .

117 Ibid.

118 “順其不識不知之性，使之共樂堯天”. See Liu Chongxiu Fujian Taiwan fuzhi, above ch 1 n 28 , at 517.

119 See Inō, above n 32, vol 3, at 324-377.

120 At 345.

${ }^{121}$ Shepherd, above 1, at 379.

122 At 370-375.

123 At 375-376.
} 
intention was probably to preserve the separate identity of the newly surrendered mountain aborigines.

The government also helped to preserve the aborigines' separate identity through adopting different administration systems for the Han and the aborigines. Han settlers paid land tax, while the aborigines paid poll tax or village tax, and aboriginal land was in principle exempt from tax. Han settlers were controlled through a household and neighbourhood registration system (baojia 保甲), which did not apply to the aborigines. ${ }^{124}$ As discussed in Chapter 3, the aboriginal companies helped to preserve the institutional distinctions between the aborigines and settlers and hence the aboriginal identity. Furthermore, aborigines also continued to live and work within their village structure, which was different from Han villages.

An example illustrates both the decline of the aborigines and the government's endeavour to preserve their livelihood and identity. After the plains aborigines moved to inner Shuishalian, the population of the local aborigines continued to decrease. In 1847 (Daoguang 27) the six villages in inner Shuishalian had 1,020 local aborigines, including 27 in the Puli village and 124 in the Meili village. ${ }^{125}$ By 1886 (Guangxu 12) Puli had six people left and Meili had one. ${ }^{126}$ These aborigines petitioned the government between 1878 and 1886 about non-payment of rent by the migrant plains aborigines. The government supported their claims, and at no time tried to eliminate the category of "Pu-Mei" aborigines. $^{127}$

In summary, with increased exposure to Han culture and Han practice, the aborigines adapted and acculturated. The "land for water" transactions were evidence of the aborigines' ability to participate in complex investments, as well as a catalyst for the aborigines to become more adapted to the Chinese ways. Having gained the ability to farm but lost the living space, some aborigines moved towards the mountain areas in search for land, and

\footnotetext{
124 See Tai, above n 32, in general, for the different administration systems of settlers and aborigines.

125 Ding, above $\mathrm{n} 105$, at 215.

${ }^{126}$ See noted by the Aboriginal Affairs Sub-prefect in Sifa cankao, above n 45, vol 1A, at 309.

${ }^{127}$ See the decrees in ibid, at 305-310.
} 
repeated the methods of land grabbing which the Han had performed on them. Government officials had tried to educate the aborigines and expected their acculturation, but had very little involvement in the actual transformation.

Despite the acculturation, the aborigines' separate identity was still identifiable. This served to maintain the residual links between the aborigines and their land. However, when an extensive land survey and land tax reform was carried out in 1886 (Guangxu 12), the adaptation and acculturation resulted in the government's disregard of aborigines as a separate group, and aboriginal land as a separate type of land.

\section{Land Tax Reform and Aboriginal Land}

Between 1886 and 1890 (Guangxu 12-16), the first Taiwan Governor, Liu Mingchuan, implemented land tax reform in Taiwan, which abolished distinctions between acculturated aborigines and settlers, and aboriginal land and settler land. The reform was the last Qing government action to alienate aboriginal land rights.

\section{A Background to the Reform}

The land tax reform was essentially revenue driven. After the crises of the 1874 Japanese invasion and the 1885 French attack on Taiwan, the Qing government tried to strengthen maritime defence in Taiwan. Recommendations were made and approved for making Taiwan as a province, which meant Taiwan could no longer rely on Fujian to provide funds for its administration and military needs. ${ }^{128}$ Governor Liu decided to survey agricultural land as one of the means to raise revenue. Liu complained that the land register had not been updated since the Daoguang years, while land reclamation continued and agricultural land had expanded. ${ }^{129}$

As discussed in Chapter 3, the Qing government kept the "fish scale [land] register" (yulin ce) to record individual pieces of land with yezhu and tenant information, and kept the transaction register (tuishou ce) to record changes of proprietary rights, including sales and

\footnotetext{
128 Although there was an arrangement for temporary financial support.

${ }^{129}$ Liu Zhuangsugong zouyi, above ch 2 n 129, at 300 and 319.
} 
pledges. The people were expected to report reclaimed land which would then be added to the register, and they could report agricultural land that was damaged, for example by flood, which would then be removed from the register. Much was relied on yezhu's initiative, and land survey was rarely conducted. This was because in the Chinese tradition, emperors were reluctant to conduct surveys of agricultural land, viewing it as disturbance to the people. ${ }^{130}$ The Qing emperors seemed to hold the same view. The problem of "hidden land" was well known by the central government, and although regulations encouraged reporting of land reclamation, there was no desire to uncover "hidden land" through land survey. For example, in 1729 (Yongzheng 7), a Taiwan Censor reported that much land was reclaimed but not registered, and weighed the problem against reasons for not surveying the land, being very uncertain as to which course to take. The Yongzheng Emperor retorted, "to investigate land for tax is not an urgent matter for the administration of Taiwan. Why did you report it at all?!" ${ }^{131}$ Guided by this principle, the Qing government did not systematically survey agricultural land in Taiwan for 200 years.

Another complaint of Liu's was that different types of land had different tax or rental obligations to the government, and it was too complicated for effective administration. Before the reform, the government classified agricultural land in Taiwan into different categories, according to a mixture of ownership and tax status. The first four types of land owners noted in the early Qing were: private owners (yehu 業户), managers (guanshi 管 事), government (guanzhuang 官莊) and aboriginal villages (fanshe 番社). ${ }^{132}$ These four types of land ownership all referred to cultivated land, as indicated by the use of the term tianyuan 田園. The first category, yehu's land, was registered private land, which was subject to the ordinary land tax. "Managers' land" in early Qing Taiwan was in fact also private land. The "managers" represented the local community to liaise with the government on tax and corvée matters, and were given some land by yehu as a reward which was exempted from land tax. ${ }^{133}$ Since in imperial China land tax was the most

\footnotetext{
${ }^{130}$ Zhao and Chen Zhongguo tudi zhidushi, above ch $3 \mathrm{n} 5$, at 71.

131 Yongzheng zhupi zouzhe, above n 8, at 43-44, “清查田糧, 非現今治臺急務, 何必汲汲奏及與此”.

132 Zhou, above n 67, at 86.

133 Ibid.
} 
important aspect of land that concerned the government, this was listed as a separate type of land.

Eventually other types of private land emerged, such as "education land" (xuetian 學田), which was in fact private property owned by educational institutes, and was often given by the government or donated by private land owners. Such lands were also distinguished from yehu's land and recorded separately, although they were not tax-exempt. ${ }^{134}$

Government estates in Taiwan also were of different types, depending on the purposes of their creation and the use of the rent. What was referred to as guanzhuang (官莊 official estate) were first reclaimed by local officials who then leased them and collected rent. In 1725 (Yongzheng 3) rental income from such estates was incorporated into the formal fiscal system and became part of the government income. ${ }^{135} \mathrm{~A}$ second type was called long'enzhuang (隆恩莊 soldier-welfare estates), which was started in 1730 (Yongzheng 8), when the government decided to purchase some estates and use the rental to provide for soldiers and their families in cases of sickness, death or other unusual occurrence. ${ }^{136} \mathrm{~A}$ third type was forfeited property (chaofeng chan 抄封產). Forfeiture of land could be triggered by rebellion, other criminal activities, non-payment of taxes or even civil disputes. ${ }^{137}$ During the late Qianlong reign, the government converted some forfeited land into the aboriginal "company land", and used the rental income to pay a monthly allowance to the aborigines of the quasi-military aboriginal companies. These were all government estates, but the receiver of the rents differed and the rents were accounted for differently. Some needed to be accounted for to the imperial coffers; others remained in local government or the military units. ${ }^{138}$

The last type of cultivated land belonged to aborigine villages. The two centuries of settlement changed aboriginal land tenure significantly. Some were registered by fa yehu

\footnotetext{
${ }^{134}$ For example, see Fan Chongxiu Taiwan fuzhi, above ch 1 n 29, at 292-293 about "education land".

${ }^{135}$ See the evolution of official estates in a memorial of the Fujian Governor in 1756 (Qianlong 21), collected in Tai'an huilu bingji [Collection of Taiwan document series C] (TWWX 176), at 19. Also see Hui, above $\mathrm{n}$ 81, at 109-112.

${ }^{136}$ Dazu diaocha, above n 25, at 991. Also see Hui, ibid, at 112-117, for accounts on soldier-welfare estates.

${ }^{137}$ Hui, ibid, at 117-123.

${ }^{138}$ At 118.
} 
and became taxable, some were distributed among villagers and became individually held land, and the rest were leased in large rent to settlers but were not registered for tax. The establishment of aboriginal companies created the "upkeep land", which was a special type of aboriginal land as the land in fact belonged to the villages that made up the companies. ${ }^{139}$

Thus, by the late Guangxu reign, much land in Taiwan was tax exempt because of the different categories of land, or tax evading because of the inaccuracy of the tax register. In search of tax revenues, Liu embarked on the land tax reform in 1886.

\section{$B$ Aboriginal Land under the Reform}

Liu's reform measures affected aborigines and their land rights more than those of other land owners. The measures included registration of all aboriginal land, preference of sale of upkeep land over redemption by aborigines, a reduction of $40 \%$ of large rent, and registration of aborigines in the same way as that of Han settlers (bianji weimin 編籍鴬民). The combined effect of eradicating the category of aboriginal land and breaking down the aboriginal society further removed aborigines from their land.

Liu's reform was not designed to target aboriginal land, rather he was looking for a simple and straightforward solution to solve the tax problems that he identified. All agricultural land in Taiwan was to be thoroughly surveyed and registered for tax. The distinctions between various categories of land were eliminated, with all land being subject to the same tax obligation.

Liu did specifically address lands associated with the aboriginal companies, namely "company land" and "upkeep land", and explain reasons why these lands should be treated as ordinary taxable land. ${ }^{140}$ Not long after the aboriginal companies were established, the company business fell into confusion. Collection of rents from "company land" and distribution of monthly allowances were delegated to company leaders, which were originally the local government's duties. "Upkeep lands" were sold or pledged against the regulations. In 1810 (Jiaqing 15), 1818-1822 (Jiaqing 18-Daoguang 2) and 1834-1838

\footnotetext{
139 As discussed in above ch 3.

${ }^{140}$ Liu Zhuangsugong zouyi, above n 129, at 305-307.
} 
(Daoguang 14-18) the government three times investigated the affairs of company land and upkeep land, to rectify rent collection issues and restore upkeep land to aboriginal hands. ${ }^{141}$ The situation continued to deteriorate. Liu complained that the companies were not functioning, rent was not collected in full, aborigines received about half of their allowance, and the upkeep land had changed hands - some many times. ${ }^{142}$ Company lands were government estates, and Liu changed rental payment to tax obligations. ${ }^{143}$ Upkeep lands were aboriginal land, but Liu argued that the land had long been sold or pledged to Han settlers, plus the government had provided for the aborigines for a century, and they had become equal subjects of the Court as settlers were. Therefore the aborigines should enter the same household and neighbourhood registration as Han settlers, and all aboriginal land had to be surveyed and registered for tax.

Liu's initial plan was to distinguish unregistered aboriginal land on which the villages collected large rent as a collective (tongtu kouliangzu) from other aboriginal land - land that was registered by fan yehu or held by individual aborigines, and the upkeep lands. ${ }^{144}$ While the latter types were to be treated the same as settler land, the former was not. But the Taipei Prefect argued that the former type of land was reclaimed by aborigines in the mountain areas, and that most of it had been controlled by Han settlers. ${ }^{145}$ The Taipei Prefect's suggestion to include unregistered aboriginal land in the reform was approved. ${ }^{146}$ Consequently all aboriginal land was to be treated in the same way as settler land.

After the thorough survey, the area of registered land increased to about six times of the area before the survey. The area of agricultural land, as last recorded during the Daoguang years, totalled about 70,148 jia, ${ }^{147}$ compared with 432,009 jia after the survey. ${ }^{148}$ It is difficult to judge the proportion of aboriginal land in the increase, as the increase included

\footnotetext{
${ }^{141}$ See the memorials, decrees and correspondence in Tai'an jiaji, above ch $1 \mathrm{n}$ 135, at 51-74; and a decree of the Fujian-Zhejiang Governor-General in Sifa cankao, above n 45, vol 1A, at 402-403.

${ }^{142}$ Liu Zhuangsugong zouyi, above n 129, at 306.

${ }^{143}$ Hui, above $\mathrm{n} 81$, at 109.

144 Sifa cankao, above n 45, at 191.

145 Dazu diaocha, above n 25, at 435-436.

146 At 435-436, 633 and 636.

147 Liu Zhuangsugong zouyi, above n 129, at 300. The record was 38,100 jia plus 3621.5 qing, which converted to about 70,148 jia in total.

148 At 318-319.
} 
uncovered "hidden land", and other types of land which were previously non-taxable or recorded separately, such as soldier welfare land, "education land", unregistered aboriginal land, aboriginal companies' upkeep land, and one particular official estate. ${ }^{149}$ What is known is that before the reform the aborigines still "had" - mostly in the sense that they had large rent rights - more land than settlers. Liu found that $60 \%$ of land in the eight coastal counties "belonged" to the aborigines - which would have included unregistered aboriginal land, land held by fan yehu and possibly land held by individual aborigines and $40 \%$ belonged to Han settlers. ${ }^{150}$ Therefore aboriginal land would have accounted for a large proportion of the increase.

Strictly speaking, registration would not have altered the nature of aboriginal land, since the rights of the aborigines over most so-called aboriginal land was to receive large rent only. However under the sweeping policies to eliminate the distinct identity of aborigines and the category of aboriginal land, the reform laid the foundation for the aborigines to further lose the residual rights over their land. This was manifested in two aspects.

Firstly, the reform shifted the tax burden from large rent owners to small rent owners. Consequently small rent owners became the registered yezhu of land. Although registration as yezhu did not necessarily convey or prove ownership over land, this move withdrew government recognition of the legitimacy of the large rent holder class and severed their only connection with land. Further, large rent owners were required to give up $40 \%$ of large rent to subsidise small rent owners for payment of tax. For those aboriginal land that had not been subject to tax, the $40 \%$ was a net loss. The poll tax, village tax and various fees that the aborigines had to pay before the reform were abolished, but the abolished amount was usually much less than the $40 \%$ of rent that they had to give up. ${ }^{151}$ As a consequence of the reduction of rent and the marginalisation of large rent owners, the aborigines received less income and experienced more difficulties in collecting rent.

\footnotetext{
${ }^{149}$ See Liu's decree in Sifa cankao, above n 45, vol 1A, at 191.

${ }^{150}$ See in Liu's memorial of 1887 in Fu Tai dang'an, above ch 2 n 119, at 262, “沿海八縣之地, 所有土 地，番居其六，民居其四”.

${ }^{151}$ See Liu Zhuangsugong zouyi, above n 129, at 303; Dan Xin dang'an, above n 53, vol 13, file No. 17212.13 and 17212.69 .
} 
The more damaging aspect was the withdrawal of protection built around aboriginal land, in particular, the emergence of a policy to facilitate alienation of aboriginal land rights. Guided by the principle that aboriginal land was to be no different from settler land, the government's response to the aborigines' petition to redeem pledged upkeep land was that "it is better to allow sale than to allow redemption". ${ }^{152}$ This was because sale was more straightforward than redemption, as redemption required clarifying past transactions which often went back a lengthy period of time and involved different parties. This policy was a departure from the efforts of the Daoguang government to restore upkeep land to the aborigines. In 1835 (Daoguang 15), the government decided that any occupation of upkeep land by Han settlers without a deed amounted to encroachment, and settlers had to return the land to the aborigines. If the encroached land had been sold to someone else, the person who encroached and sold the land had to return the price to the purchaser, and the land would revert back to the aborigines. If the land was sold or pledged by the aborigines, as opposed to being encroached upon, the aborigines could redeem the land at half or onethird of the original price. If the original purchaser or pledgee had further alienated the land and the land had new right holders, the aborigines could still claim half of it back. ${ }^{153}$ Although aboriginal lands were alienated regardless of government bans before Liu's reform, government policies before the reform were often a type of positive discrimination for the benefit of the aborigines. In contrast, Liu's government encouraged sale of aboriginal land, probably for reasons of expediency, but it also reflected the government's growing disregard for aboriginal land rights. As such Liu's government withdrew the protection that was previously afforded to the aborigines, and sped up alienation of the residual aboriginal land.

In summary, by the late period of Qing rule, most of the plains aborigines were acculturated. Liu Mingchuan's policies towards aboriginal land during the land reform were both the result of the acculturation after 200 years of settler-aborigine interaction, and a cause of further breakdown of aboriginal communities, which affected the aborigines' residual land rights. The reform treated aborigines as no different from settlers, and aboriginal land as

152 Sifa cankao, above n 45, at 336-337.

${ }^{153}$ Tai'an jiaji, above $\mathrm{n} 141$, at 64-65. 
no different from settler land. Apart from further breaking down aboriginal communities, it strengthened the claims of Han small rent owners over land while weakening those of the aborigines, caused difficulties in rent collection, and accelerated aboriginal land alienation. The reform did not change aboriginal land rights overnight, but rather it set aboriginal land rights on a new path of diminishment and alienation. It laid a foundation for the Japanese rearrangement of aboriginal land.

\section{$V$ Three Actors}

The frontier society was dynamic and full of action, reaction and interaction by the three actors in Qing Taiwan's political scene - the government, the settlers and the aborigines. Each, acting in their own interests, played an important role.

Throughout the Qing period, Han settlers had the financial advantage and cultural domination over the aborigines, and their interests were to obtain land from the aborigines, in whatever form that they found to be allowed by the circumstance - but not necessarily allowed by the government.

As one of the important actors, the aborigines actively participated in the frontier development - resisting Han encroachment, litigating for their land ownership and rent rights, and becoming adapted to Han culture, especially agricultural and commercial practices. However pressed by expanding Han settlement, the aborigines retreated step by step. They first lost their land ownership, then much of their rent. Some of them - but not many - adapted and became prosperous; some moved to new settlements and flourished belatedly, after they had lost their ancestral land. Taiwanese aborigines were fighting a battle that they could not win, until in the end not much was left to fight for.

The process of land loss was a long one, thanks to the Qing government's resolution to protect aboriginal land rights for most of the time. However the government's overriding concerns were security and social stability. Where these interests were not threatened, it did not try to intervene in private transactions between settlers and aborigines. Where conflicts or complaints arose, the government was generally supportive of the aborigines, unless its own interests were at stake. When threats to imperial security came from a 
different direction and the needs of the government changed, government protection of aboriginal land rights was compromised, and finally withdrawn.

The plains aborigines continued on their way to completely losing their residual rights over their land, even if Japan had not become Taiwan's new master. But Japan took over Taiwan just a few years after Liu Mingchuan's reform, and any connections that indicated the aborigines were the original owners of the land were severed in a swift and clear-cut manner by the Japanese administration.

The aborigine-settler land transactions and aboriginal acculturation discussed in Chapter 4 and this chapter mostly related to the plains aborigines, who were exposed to the influence of Han settlement. The mountain aborigines' independence and land rights remained largely intact throughout the Qing period. Under the Japanese administration, they were to experience fatal changes. 


\section{Chapter 6}

\section{Aboriginal Land Tenure under the Japanese Colonisation}

Awakening from 200 years of "substantial "national isolation", ${ }^{1}$ and in an effort to revise the unequal treaties imposed by the Western powers and to achieve equal status with the West, Japan embarked on a journey to build a modern nation state in the late $1800 \mathrm{~s}^{2}{ }^{2}$ The 1868 Meiji Restoration marked the start of that modernisation process. In 1872 sale of land was permitted, in 1885 a cabinet system was established, in 1889 a constitution following the Prussian and Austrian models was promulgated, and in 1890 the first national election was held and the Imperial Diet was convened. ${ }^{3}$ Japan adopted modern legal institutions and followed Western imperialist models, and employed them in the colonisation of Taiwan.

This chapter examines how the Taiwan Sōtokufu (總督府 Office of the Governor-General) used its modern legal institutions to reform land tenure in Taiwan and administer Taiwan's aboriginal territories, and the effects of such reforms and administration.

Part I discusses the 1874 Mudanshe Incident, where Japan and the Qing government engaged in lengthy negotiation about the aboriginal territories following the Japanese occupation of southern Taiwan. This Part highlights the contrasting legal concepts the parties employed, and argues that these concepts underpinned the parties' different colonisation styles.

Part II outlines Japan's objectives in Taiwan, the legal instruments used, and Japan's views of the legal status of the Taiwanese aborigines and ownership of aboriginal land. It points out the Western origins of such objectives, instruments and views.

Part III traverses the Sōtokufu's reform of rural land tenure in western Taiwan and analyses the effects of the reform. Part IV documents the government's action on unreclaimed and forest land, a category that was equivalent to the Qing's "wasteland". This Part considers

\footnotetext{
${ }^{1}$ Hirakawa Sukehiro “Japan's Turn to the West” (trans Bob Tadash Wakabayashi) in Marius B Jansen (ed) The Cambridge History of Japan Volume 5: The Nineteenth Century (Cambridge University Press, Cambridge, 1989) 432, at 432.

2 At 473. Also see Kenneth B Pyle "Meiji Conservatism” in Jansen (ed), ibid, 674, at 689.

${ }^{3}$ Marius B Jansen "Introduction”, in Jansen (ed), ibid, 1, at 28-32.
} 
Qing and Japanese approaches towards aboriginal land, and highlights Japan's conscious emulation of the West.

Part V concludes that Japan pursued an essentially Western colonialist strategy in Taiwan, making Japan a kind of surrogate Western imperialist state in Asia. Western concepts of international law and colonisation, and Western instruments regarding land tenure marked Japan's departure from the Qing-style expansion and colonisation.

\section{The Mudanshe Incident}

The Mudanshe Incident was important in the history of colonisation of Taiwan, not only because it prompted the Qing government to abruptly change its policies towards the aborigine territories in Taiwan, but also because it was the precursor to the Japanese colonisation of Taiwan that commenced in 1895. This incident serves to highlight the two empires' different conceptions towards expansion and colonisation, and the different legal traditions that supported these conceptions.

\section{A The Emergence of Japanese Ambitions in Taiwan}

Japan's desire to acquire Taiwan was displayed in its 1874 expedition to Taiwan, known as the Mudanshe Incident. This occurred only a few years after the Meiji Restoration. This first colonial attempt was covert and was not universally supported within the Japanese government, but it led to Japan's colonisation of Taiwan two decades later.

The incident was driven by Japan's ambitions relating to Ryukyu (Liuqiu 琉球, present day Okinawa) as well as Taiwan. In 1871 (Tongzhi 10), a Ryukyuan ship was wrecked off Taiwan's southern coast. Ryukyu was at that time a vassal of the Qing Court, but it also paid tribute to Japan. The ship was on its return journey after sending tributes to the Qing Court. After the shipwreck 54 crewmen were killed by the aborigines of the Botan (Mudan 牡丹) and Kusukut (Gaoshifo 高士佛) villages. Twelve surviving crewmen were rescued by a Han settler, who sent them to the Fengshan county government. From Fengshan they were sent to the Taiwan prefectural government, and then to the Fujian provincial 
government, which accommodated them while they waited for a ship to return home. ${ }^{4}$ The Fujian government reported the incident to the Emperor and proposed to punish the aborigines, ${ }^{5}$ but as the matter unfolded this appeared to have not been carried out. The Fujian government eventually sent the survivors back to Ryukyu with financial assistance, as it did many times before when Ryukyuan ships were wrecked in Taiwanese waters. ${ }^{6}$ The matter appeared to have settled.

The 1871 incident was not the first time that the Qing government had to deal with an incident of this kind. Cases where the non-acculturated aborigines in the south attacked shipwreck survivors had been increasing since the 1860s because of growing presence of foreign ships in Taiwanese waters. There had been an attack on a British vessel (the Doob) in 1866, and attacks on another British vessel (the Sylvia) and a United States vessel (the Rover) in 1867 . The attacks had caused some international concern and diplomatic problems for the Qing Court, but no serious consequences ensued. ${ }^{7}$ The 1871 incident, however, not only changed the course of history for the Qing and Japan, but also the fates of the Taiwanese aborigines, because it coincided with Japan's growing ambition to expand.

The idea of sending an expedition to Taiwan emerged within Japan in 1872, as it seemed to serve multiple purposes. It was an opportunity to claim Japan's sovereignty over Ryukyu, to occupy the aboriginal territory of Taiwan, to realise national prestige and security, and to ease the mounting discontent among the ex-samurai and calm the domestic situation through an expansive expedition. ${ }^{8}$

The preparation was conducted in secret, for fear of intervention from the international community. ${ }^{9}$ When it eventually became known, the Russian, the United States and the

\footnotetext{
${ }^{4}$ See a memorial of Tongzhi 11 (April 1872) in Jiaxu gongdu chaocun [Documents relating to the 1874 incident] (TWWX 39), at 1-2 (“Jiaxu gongdu”).

${ }^{5} \mathrm{Ibid}$, “現飭㗌灣鎮、道、府認真查辦，以憼强暴”.

${ }^{6}$ This occurred in every reign of the Qing Dynasty, as many reports are collected in various volumes of Ming Qing dang'an, above "Introduction" n 55.

${ }^{7}$ Inō Taiwan wenhua zhi, above "Introduction" n 32, vol 3, at 80-81.

${ }^{8}$ Norihito Mizuno "Qing China's Reaction to the 1874 Japanese Expedition to the Taiwan Aboriginal Territories” (2009) 16 Sino-Japanese Studies 99, at 101-102.

${ }^{9}$ Edward H House The Japanese Expedition to Formosa (Tokyo, 1875), at 15-16. House was an American journalist engaged by Japan to report on and justify the expedition.
} 
British governments all took action to forbid or warn against involvement of ships or nationals of their respective countries in the expedition, assuming that it amounted to a declaration of war against the Qing. ${ }^{10}$ Pressure from the United States resulted in the Japanese government's decision to halt the expedition, but nevertheless the naval commander, Sagō Tsugumochi, had a steamship set sail from Nagasaki for Taiwan in late April 1874, arriving in the aboriginal territory in southern Taiwan early the next month. ${ }^{11}$

Japan's pretext for sending the expedition was to punish the Mudan aborigines, but the preparation before and activities during the expedition all pointed to colonisation of Taiwan. As part of the expedition, livestock was brought and civil engineering material was sent. ${ }^{12}$ During the six-month period of Japanese occupation, there was barely any "punishment" activity. Only one skirmish occurred after "provocation" by the Mudan aborigines, and one attempt was made to attack the Mudan and Gaoshifo villages, but in the latter case the villagers fled before the Japanese arrived. ${ }^{13}$ The Japanese occupiers spent their remaining time on informing the neighbouring aborigines of Japan's "pacific design", trying to subjugate them, collecting information about the territory and the people, planting crops and making plans to colonise the territory. ${ }^{14} \mathrm{~A}$ spot for "permanent occupation" was chosen, and methods of political control were conceived. ${ }^{15}$ Scholars have also recognised that Japan's real intention was to colonise Taiwan. ${ }^{16}$

The expedition ended with an agreement signed in October 1874 between the Qing and Japan. The Qing paid a large indemnity to Japan, in the name of compensation for the families of the killed crewmen and the infrastructure that Japan built in southern Taiwan. The Japanese force withdrew. ${ }^{17}$ Japan hence ended its colonial venture in Taiwan

\footnotetext{
${ }^{10}$ At $18-22$.

${ }^{11}$ At $19-20$.

${ }^{12}$ Fujii Shizue Taiwan yuanzhumin shi: zhengce pian [History of Taiwan aborigines: the policy chapter] (Taiwan Historica, Nantou, 2001), at 1.

${ }^{13}$ See House, above n 9. House recorded details of the activities during the whole expedition, and the two events were recorded at 74 and 115.

${ }^{14} \mathrm{Ibid}$, in general, but in particular, at 62 and 142.

${ }^{15}$ At 151 and 155.

${ }^{16}$ For example, Leonard Gordon "Japan's Abortive Colonial Venture in Taiwan, 1874” (1965) 37(2) Journal of Modern History 171-185.

${ }^{17}$ See the text of the agreement in Tongzhi Jiaxu ribing qin Tai shimo [Documents on the 1874 Japanese invasion of Taiwan] (TWWX 38), at 178-179 (“Jiaxu shimo").
} 
triumphantly, the result of employing international law theories on sovereignty with the backing of military power. Indeed sovereignty was the key issue that the two parties debated.

\section{$B$ Sovereignty over the Aboriginal Territories}

\section{Japan's argument}

Throughout the 1874 expedition, Japan maintained that it was justified in entering and occupying the aboriginal territory of Taiwan, because the Qing did not have sovereignty over "savage" land. Japan's introduction of and arguments about the notion of sovereignty were entirely informed by international law doctrines. These doctrines and the theoretical justification for the expedition were provided by Charles Le Gendre, a former US consul to Amoy (Xiamen) turned Japanese advisor. Le Gendre was familiar with Taiwan's aboriginal territory because of the Rover incident in 1867, and he became the instigator, facilitator and advisor of the Japanese expedition. ${ }^{18}$ Japan's use - or misuse - of European international law was itself a sign of Japanese modernisation.

Introducing the doctrines of possession and sovereignty, Le Gendre argued that there was no discovery or conquest of the aboriginal territories by the Qing. The evidence was that Qing maps did not show details of the eastern part of Taiwan, and the Qing had failed to subjugate the aborigines. ${ }^{19}$ Furthermore, the Qing had no intention to occupy the aboriginal territory, since the abandonment of a temporary fort was a renunciation of intention. ${ }^{20}$ More importantly, the Qing had failed to exercise any de facto control over the aborigines and to perform its obligation to civilise the aborigines, which was essential for possession and sovereignty. ${ }^{21}$ Le Gendre concluded that there was no fact of Qing discovery of aboriginal Taiwan, and no intention or fact of possession.

\footnotetext{
${ }^{18}$ For Le Gendre's role in the expedition, see Sandra Caruthers "Charles Le Gendre, American Diplomacy, and Expansionism in Meiji Japan, 1868-1893 (PhD diss, University of Colorado, 1966); Li Li and Zhao Guohui "Li Xiande yu Riben diyici qin Tai" [Le Gendre and Japan's first invasion of Taiwan] [2007] 3 Jindaishi yanjiu 100-116.

${ }^{19}$ Charles Le Gendre Is Aboriginal Formosa a Part of the Chinese Empire? An Unbiased Statement of the Question (Lane, Crawford \& Co, Shanghai, 1874), at 2-6.

${ }^{20}$ At 10.

${ }^{21}$ At 8-12 and 19.
} 
Guided by Le Gendre's advice, and quoting international law experts such as Emme de Vattel and Johann Bluntschli, Japan argued that sovereignty came from possession, and actual possession required administrative acts. ${ }^{22}$ According to Japan, since the Qing failed to implement law (fazhi 法治), station officials (sheguan 設官), exercise political control and education (zhengjiao 政教), or bring civilisation (kaihua 開化) in the aboriginal territory or to the aborigines, the Qing had not exercised administration over the aborigines. Therefore the Qing did not have sovereignty over the aboriginal territory. ${ }^{23}$

In the eyes of Le Gendre and Japan, the aborigines were "savages" without a sovereign (wuzhu yeman 無主野蠻), and hence Japan was free to send an expedition against the people and occupy the territory. ${ }^{24}$ To this end they had to advance contradicting arguments. On the one hand, to disprove Qing sovereignty, Le Gendre acknowledged that the aborigines asserted "unlimited independence and absolute sovereignty" over their land. On the other hand, to justify Japan's occupation, Le Gendre argued that under the "law of nations" other nations could "seize upon the territory" which was "occupied by a wild race", and "hold it not only against the natives themselves, but against everyone". ${ }^{25}$ Japan and Le Gendre clearly chose the arguments that served their objectives.

Furthermore, Japan argued that its expedition was carrying out a great civilising mission. To change the state of affairs, where the aborigines became a threat to passing ships, the aborigines must be "either pacified or exterminated". ${ }^{26}$ Japan's expedition against the aborigines was to "assist the cause of humanity for all nations", which the Qing had failed to perform. ${ }^{27}$ It appears that Japan did believe in social Darwinism ${ }^{28}$ and was proud to

\footnotetext{
${ }^{22}$ Letter of the Japanese plenipotentiary Ōkubo Toshimichi in Jiaxu shimo, above n 17, at 153-154.

${ }^{23}$ At 144-146 and 158-159.

${ }^{24}$ See letters of the Japanese representative Yanagihara Sakimitsu in ibid, at 105 and 109. The term wuzhu could also mean terra nullius. Japan's arguments in effect asserted that the aboriginal territory was terra nullius.

${ }^{25}$ Le Gendre, above $\mathrm{n} 19$, at 15.

${ }^{26}$ At 18.

${ }^{27}$ House, above $\mathrm{n} 9$, at 4.

${ }^{28}$ For example, see Riju shiqi yuanzhumin xingzheng zhigao [Administration of aborigines during the Japanese period, translation of Ribanshikō compiled by the Police Administration Bureau, Taiwan Sōtokufu] (Taiwansheng wenxian weiyuanhui, Nantou, 1997), vol 1, at 149 ("Xingzheng zhigao"); Takekoshi Japanese Rule in Formosa, above "Introduction" n 6, at 233.
} 
perform the "great and glorious work" of colonising and "civilising" the indigenous territories and peoples of Taiwan. ${ }^{29}$

The international law doctrines of discovery, possession and terra nullius provided justifications for Western expansion and colonisation of indigenous territories. During the negotiation Japan for the first time applied the modern legal concepts that it had learned. Following "the enlightened opinions of European jurists", ${ }^{30}$ Japan regarded the aborigines as having no status under the international law, and their land as terra nullius. The same line of reasoning was to be followed after 1895 in justifying the Sōtokufu's assertion of government ownership over the aboriginal territory.

Japan applied the doctrines as though it was the absolute truth, yet in the Western world there had been serious debates about and examinations of these legal doctrines, especially in terms of justice towards the indigenous peoples. The terra nullius doctrine was the subject of debate as early as the $17^{\text {th }}$ century, and by the mid- $18^{\text {th }}$ century had stopped being applied in North America. ${ }^{31}$ Its later application in Australia was because of an initial misunderstanding that the continent was so sparsely populated that it looked like "an empty continent", and even so criticism of its injustice towards the indigenous peoples had arisen from inside and outside the government in Britain and Australia in the early 1800s. ${ }^{32}$ Japan was either ignorant of the controversy about the doctrine, or chose to ignore it because it did not serve Japanese purposes. As a new member in the power game and lacking a philosophical and ideological basis to the international law doctrines, Japan simply adopted such doctrines as suited it.

\footnotetext{
${ }^{29}$ Takekoshi, ibid, at vii, "A Word to My Readers".

${ }^{30}$ Le Gendre's memorandum of 5 October 1874, quoted in Caruthers, above n 18, at 225.

${ }^{31}$ Stuart Banner "Why Terra Nullius? Anthropology and Property Law in Early Australia" (2005) 23 Law and History 95, at 95 and 97.

${ }^{32}$ At 96.
} 


\section{Qing response}

The Qing clearly did not grasp the legal implications of its own action and Japan's action in the same light, because the Chinese system under which the Qing still operated was different from the Western one.

To begin with, before the incident the Qing had recognised the aborigines' autonomy, and had no notion of sovereignty in the modern sense. After the incident occurred the Taiwan Circuit Intendant thought that the Mudan village was “the aborigines' territory" (fanjie 番 界). As a result the Qing could not stop Japanese interaction with the Mudan aborigines, but could only monitor the situation for the safety of the western territory. ${ }^{33}$ This was because the Chinese tradition had no notion that "savages" lacked legal status, or that their territory could be possessed by any civilised country at will. To fight the aborigines as an enemy and take their land was one thing, but to claim possession of the territory as though it was terra nullius was another. Neither was justifiable, but the two accorded quite different status to the aborigines, and represented different philosophies regarding expansion.

After a British diplomat's enquiry about whether the area where the aborigines lived was Chinese territory, the central government started to claim that the aboriginal territory was within China's realm. ${ }^{34}$ Even so, when declaring the land to be China's territory, officials at the Foreign Affairs Office (Zongli yamen 總理衙門) still plainly conceded that the people were not subject to Chinese law. ${ }^{35}$ Later, officials stated to Japanese representatives that although the government did not subject the aborigines to its law, the aborigines were still subject to China's administration. ${ }^{36}$ The changes indicated the process of Qing officials'

\footnotetext{
33 “牡丹社系屬番界，彼如自往剿辦，在我勢難禁止”. See the Intendant's letter to the Fujian-Zhejiang Governor-General in Jiaxu gongdu, above $\mathrm{n}$ 4, at 5. The letter was not dated, but it was before the Japanese expedition and when the Japanese carried out investigation in the Langqiao area.

${ }^{34}$ See Prince Gong's memorial to the Emperor in Jiaxu shimo, above n 17, at 1, “薹灣生番地方, 系屬中 國版圖”. As scholars have heatedly debated how “Chinese” the Manchu Qing was, and some have argued that the Qing was not China, it is worth noting here that throughout the negotiation the Qing used the term "China" 中 國 to refer to the Qing Empire. Also see the same references in Qing Muzong shilu xuanji [Selected veritable records of the Tongzhi Emperor] (TWWX 190), for example, at 145, 148 and 149. This part therefore follows the original text in using the terms "China" and "Chinese" instead of replacing them with "the Qing".

35 “其人踓不治以中國之法，其地究不外乎中國之土”. Jiaxu gongdu, above n 4, at 11 .

${ }^{36}$ Jiaxu shimo, above n 17, at 38, “向未繩以法律, 總屬中國管轄之人”.
} 
gradual and partial understanding, and reluctant acceptance, of the modern notion of sovereignty as the scenario developed. It was under pressure from Japan and out of the desire of self-defence that the Qing government abandoned its belief in the aborigines' independence, and asserted sovereignty over the aboriginal territory.

The point was not about whether the Qing did have sovereignty over the aboriginal territory, the notion of sovereignty itself being a Western invention. Rather it shows that the modern concept of sovereignty had been unknown to the Qing. Instead, the Qing relied on the traditional Chinese theory of governance in responding to Japan's challenges regarding administration and civilisation. Quoting the Book of Rites (Liji 禮記), the Confucian classic that records the administration and rites of the Zhou Dynasty (1046-256 BCE), the Qing argued that its administration of the aborigines followed the ancient practice of carrying out administration without requiring the peoples to change their customs or depart from what they were accustomed to. ${ }^{37}$ Therefore, China exercised administration and implemented law according to the local situations and customs. The Qing hence still operated in a deeply Chinese legal and cultural framework.

The Qing also argued that it was a common reality, in China as well as in many other countries, that in the administration of a country "the law could not always be applicable, local offices and armies could not be stationed in all places, civilisation could not immediately show influence, and the qualities of the people could not be the same". ${ }^{38}$ Interestingly, Le Gendre readily acknowledged in an 1871 report to the United States government that the status of the mountain territories under the Qing was similar to that of the Indians territories under the United States government, or the aboriginal territories in Australia and New Zealand under the British. Hence he recognised Qing sovereignty over

\footnotetext{
${ }^{37}$ See the Qing government's dispatch to the Japanese Foreign Affairs Department (waiwu sheng 外務省) in ibid, at 5, “即禮記所雲不易其俗，不易其宜之意”.

${ }^{38}$ Letter to Ōkubo Toshimichi in ibid, at 161. “法律不能盡繩, 郡縣官兵不能遍設, 文教不能即通, 民 質不能即齊, 凡此皆治國之恒情”, “且不獨中國版圖如此類者甚多, 即各國所屬版圖, 如此類亦恐 不少”. Richard Boast The Native Land Court vol 2: A historical study, cases and commentary 1888-1909 (Thomson Reuters, Wellington, 2015), at 158 and 252-253, discusses a similar situation in New Zealand and the Spanish Latin America. Also see Shiri Pasternak "Jurisdiction and Settler Colonialism: Where Do Laws Meet?" (2014) 29 Canadian Journal of Law and Society 145; Lauren Benton A Search for Sovereignty: Law and Geography in European Empires 1400-1900 (Cambridge University Press, Cambridge, 2010).
} 
the aboriginal territory before he was employed by Japan. ${ }^{39}$ This recognition was confirmed by the United States and British assumption that the expedition was declaring war against the Qing. However, the recognition did not serve Japanese interests, so Le Gendre withdrew it and painstakingly tried to prove that the Qing lacked sovereignty over the aboriginal territory.

Thus the two parties argued on different bases. Japan advanced the modern theories of nation state and sovereignty. The administration of the Qing Empire, following the Chinese tradition, "distinguished between civilised Chinese and uncivilised aborigines in the administration" (huayifenzhi 華夷分治). Unlike the notion of state sovereignty, there were no clear boundaries of the empire. ${ }^{40}$ Against Japan's use of international law theories, the Foreign Affairs Office answered, quite rightly, that international law was compiled by the Western countries and did not reflect the Qing practices, and therefore was not a basis for the negotiation. ${ }^{41}$

The respective beliefs of the Qing and Japan about state sovereignty and empire building determined their attitudes towards the aborigines, and in turn towards aboriginal land. The Qing tradition provided a footnote to its policies regarding aboriginal land in the previous 200 years, while Japan's argument provided a guide for the Japanese policies when its time came. In other words two competing discourses and conceptions of law were at stake.

\footnotetext{
${ }^{39}$ Charles W Le Gendre Reports on Amoy and the Island of Formosa (Government Printing Office, Washington, 1871), at 45-48.

${ }^{40}$ For a thorough discussion of the two different theories of nation states and empires, see Chang Chi-hsiung "Dongxi guoji zhixu yuanli de chayi: 'zongfan tixi' dui 'zhimin tixi'" ("A Comparison of Eastern and Western Principles of International Order: Suzerainty vs Colonization”) (2003) 79 Zhongyang yanjiuyuan jindaishi yanjiusuo jikan 47 .

41 “萬國公法者，乃近來西洋各國編成之物，殊無載我清朝之事，故不引此論為論辯之用”。Quoted in ibid, at 67-68. Also see House, above n 9, at 195; Caruthers, above n 18, at 222. However it should be noted that occasionally the Qing also tried to quote international law.
} 


\section{Colonising Taiwan}

\section{A Following Western Colonial Examples}

Not only did Japan attempt to justify its colonial action through employing Western legal theories, Japan's motives and goals to acquire Taiwan in 1895, and the administration of Taiwan after that, were also largely informed by European examples.

\section{Power and exploitation}

Despite the exercise of 1874, Japan's motive to annex Taiwan was abstract and vague rather than substantive and clear at first - other than the recognition that the annexation would bring it "national eminence" and "international prestige", ${ }^{42}$ and provide an overseas colony for exploitation.

Desiring to abolish the unequal treaties the Western powers imposed on Japan, and to transform from the "bullied" to the bully, Japan was determined to follow Western examples. Japanese politicians celebrated Japan's performance with its first overseas colony as a proof of Japan's "worthiness to be admitted into the community of the world's great colonial powers". ${ }^{43}$ The fundamental drive was to be like the other great colonial powers and to create "a new, European style empire on the edge of Asia". ${ }^{4}$

The European powers' exploitation of resources of their colonies also informed Japan's action. Although it was said that Japan did not have a clear idea what practical benefit Taiwan could bring when it acquired Taiwan, ${ }^{45}$ Japanese officials were determined that Taiwan as a colony was to be exploited for the benefit of Japan. As soon as Japan took over Taiwan, the Chief of Civil Administration (minsei chōkan 民政長官) recognised that a priority was to exploit the rich resources in the mountain territories, in particular camphor

\footnotetext{
42 Mark R Peattie "Introduction” and Mark R Peattie "Japanese Attitudes toward Colonialism, 1895-1945" in Myers and Peattie (eds) The Japanese Colonial Empire, above "Introduction" n 26, at 10 and 82 respectively.

43 Takekoshi, above n 28, at 2. Takekoshi was a member of the Japanese Diet.

44 Japanese Foreign Minister Inoue Kaoru in 1887, quoted in Marius B Jansen "Japanese Imperialism: Late Meiji Perspectives" in Myers and Peattie (eds), above n 42, 61, at 64.

45 George W Barclay Colonial Development and Population in Taiwan (Princeton University Press, Princeton, 1954), at 7.
} 
and timbers, but also mines and agricultural products. ${ }^{46}$ This clearly shows that prestige as such was not the only goal - prestige and exploitation went together. As will be demonstrated later in this chapter, all Japanese actions regarding land had a clear objective of exploitation.

\section{Law and administration}

For the administration of Taiwan, Japan consulted Western advisors, managed it as a Western style colony and governed it through a series of laws made in modern form, unlike the Qing which simply governed Taiwan as a prefecture within the ordinary administration.

After annexation, Japan considered two options recommended by two Western advisors to follow the French model and treat Taiwan as "a prefecture of Japan", or to follow the British model and treat Taiwan as a "legally, politically, culturally and financially separate" colony. ${ }^{47}$ The government decided on a compromise of these two models, and treated Taiwan as a colony with an ultimate goal to integrate. ${ }^{48}$ Taiwan was governed by a Governor-General. The 1898 "Law concerning Laws and Regulations to be Enforced in Taiwan" (known as "Law 63") and its subsequent amendments and re-enactments granted the Sōtokufu the power to make ordinances, which had the same effect as laws of Japan, provided that they did not conflict with Diet-enacted laws or Japanese imperial ordinances already in force in Taiwan. ${ }^{49}$ The Governor-General presided over the Legislative Council of the Sōtokufu, and usually had the final authority over legislation. In effect, the GovernorGeneral exercised legislative, executive and judicial powers with high a degree of autonomy, ${ }^{50}$ and was the "virtual sovereign" of Taiwan. ${ }^{51}$

\footnotetext{
${ }^{46}$ Xingzheng zhigao, above n 28, vol 1, at 3 .

${ }^{47}$ Edward I-te Chen "The Attempt to Integrate the Empire: Legal Perspectives" in Myers and Peattie (eds), above n 42, 240, at 249. Takekoshi, above n 28, at 25-38 also made detailed comparisons of various styles of European colonies.

${ }^{48}$ Chen, ibid, at 241 and 269.

${ }^{49}$ At 248 and 259-260.

${ }^{50}$ Tay-sheng Wang Legal Reform in Taiwan under Japanese Colonial Rule, 1895-1945: The Reception of Western Law (University of Washington Press, Seattle, 2000), at 39.

${ }^{51}$ Harry J Lamley "Taiwan under Japanese rule, 1895-1945: the vicissitudes of colonialism" in Murray A Rubinstein (ed) Taiwan: A New History (Revised ed, Routledge, New York, 2015) 201, at 222.
} 
As a rule, Japanese laws were not enforced in Taiwan, unless it was the intention of the law or was provided by an imperial ordinance, and with modifications. ${ }^{52}$ The successor to Law 63, the 1921 "Law Concerning Laws and Regulations to be Enforced in Taiwan" (known as "Law 3") altered this approach, and made the application of Diet-enacted laws a principle, rather than an exception. ${ }^{53}$ However the legal system in Taiwan remained separate until the end of Japanese rule, and legal integration was never achieved. ${ }^{54}$ Thus, throughout the whole period of Japanese rule Taiwan remained an unintegrated part of the Japanese empire.

Japanese administration nominally covered the whole island, but the administration and civilisation did not apply to all of Taiwan at first. The areas where the government had full control of were the "regular administrative districts" (putong xingzhengqu 普通行政區), while the territories occupied and controlled by the aborigines were the "special administrative districts" (teshu xingzhengqu 特殊行政區) or “mountain areas” (shandi 山 地). Following the Qing classification of the aborigines, the Japanese government recognised that there were acculturated aborigines (shufan 熟番), semi-acculturated aborigines (huafan 化番) and non-acculturated aborigines (shengfan 生番). Acculturated aborigines lived in the regular administrative districts and had a "civilisation level equal to that of the Han Chinese". 55 The acculturated aborigines were treated no differently from the Chinese, and they lost their status as "aborigines" under the Japanese administration. ${ }^{56}$ Han Chinese who stayed in Taiwan after the Japanese takeover and the acculturated aborigines were both referred to as "natives" of the island (bendao ren 本島人, J. hontōjin). ${ }^{57}$

\footnotetext{
${ }^{52}$ Chen, above n 47, at 254.

${ }^{53}$ At 256. Also see discussions in Wang, above $\mathrm{n} 50$, at 44.

${ }^{54}$ Chen, ibid, at 253, 266 and 269.

55 Xingzheng zhigao, above n 28, vol 1, at 151, “開化程度達至同于漢人”.

${ }^{56}$ At 149.

57 Wang Taiwan falüshi gailun, above ch 3 n 8, at 109. In some cases "natives" include Han Chinese and all aborigines, to be distinguished from Japanese and foreigners. See Chan Su-Chuan "Taiwan pingpuzu de shenfen rending yu bianqian (1895-1960) - yi hukou zhidu yu guoshi diaocha wei zhongxin" [The ascertainment and evolution of the plains aborigines' identity: from the perspective of the household registration system and census] (2005) 12(2) Taiwanshi yanjiu 121, at 135.
} 
The laws of the Sōtokufu and applicable Japanese laws applied to the natives, but they did not enjoy the constitutional rights of Japanese nationals. ${ }^{58}$ One level down were the semiacculturated aborigines and non-acculturated aborigines, who were "barbarians" (fanren 蕃人, J. banjin). The "barbarians" lived outside the regular administrative districts and government laws did not apply to them.

The category of semi-acculturated aborigines was fluid, as they had the potential to become imperial subjects once their civilisation level was advanced. ${ }^{59}$ Similarly, the boundaries between the regular administrative districts and special administrative districts were imprecise. In 1903 the Chief of Civil Administration clarified that the guard lines, which the Japanese inherited from the Qing and extended, were not the boundary marker of the mountain areas. Instead the Han Chinese's customary recognition of mountain areas was to be the guide for determining the mountain areas. ${ }^{60}$ This situation to some extent resembled that under the Qing, but unlike the Qing, the Japanese government in principle asserted authority over the aboriginal territory and ownership of the land.

Therefore, Japan's objective, administration and legal institutions concerning Taiwan were of typical Western style, although in practice, there was some continuity from the Qing arrangements regarding the aborigines. The continuity was superficial, as Japan's treatment of the people and land in aboriginal Taiwan formed a huge contrast to that of the Qing.

\section{B Land and People}

\section{Declaration of government ownership}

As at the time of the Japanese takeover, land in the western part of Taiwan was densely populated and controlled by Chinese settlers, who had their own commercial and land practices. The mountain areas were controlled by the aborigines who had not been brought under the government control. Land tenure could not be changed immediately, but the government lost no time in declaring ownership over forest and unreclaimed land.

\footnotetext{
${ }^{58}$ Wang, above $\mathrm{n} 50$, at 174.

${ }^{59}$ Xingzheng zhigao, above n 28, vol 1, at 151-152.

60 At 241-242.
} 
To achieve the goal of exploitation, in October 1895 (a few months after the takeover), the colonial government had already issued an ordinance declaring that forest and unreclaimed land (senlin yuanye 森林原野) belonged to the government unless claimants could prove "ownership" through producing "land documents or other certain evidence", ${ }^{61}$ or as the Chinese language version put it, "evidence from previous owners and land deeds". ${ }^{62}$

Under the Qing system, only farm lands were surveyed and registered, and therefore forest land or unreclaimed land would not have been on record. Land deeds were made when land transactions occurred. The aborigines would not have land deeds if the forest land was their ancestral land. In some cases the aborigines let Han settlers extract resources in return for a fee, but no land deed would be made if the agreements did not concern land per se. Therefore as could be anticipated, most land fell into the category of government land. The Ordinance was not followed by investigation of titles and survey of unreclaimed and forest land until 1911, and it was in effect a pre-emptive declaration by the government.

Apart from making forest and unreclaimed land government-owned in law, the government also controlled the use of the forest land. The 1895 Ordinance provided that apart from those who held a licence issued by the Qing government before the takeover, no one was to cut timber, reclaim land or manufacture camphor. ${ }^{63}$ Those who held a licence issued by the Qing government had to apply to the colonial government for a new licence. ${ }^{64}$ The Rules on Control of Aboriginal Territory 1898 further clarified procedures for entering and retrieving resources from aboriginal territory. ${ }^{65}$ In 1900, an Ordinance on Occupation of Land in the Mountain Areas was made to exclude non-aborigines from occupying land in

\footnotetext{
${ }^{61}$ Ordinance on Government-owned Forest Land and Camphor Manufacture 1895 (No 26) 公[官]有林野及 樟腦製造業取締規則, cl 1, “無證明所有權之地券或其他確證之山林原野者, 全部鴬公[官] 有”. See the Ordinance in Taiwan zongdufu dang'an zhongyiben [Chinese translation of the administrative files of the Taiwan Sōtokufu] (Taiwansheng wenxian weiyuanhui, Nantou, 1992), vol 1, at 62. Unless otherwise specified, the statues referred to or quoted in this chapter are taken from Xu Guo-zhang (trans) Taiwan zongdufu gongwen leizhuan: lüling shiliao huibian [Official documents of the Taiwan Sōtokufu: legislation collection] (Taiwan Historica, Nantou, 2012) vol 1\&2.

${ }^{62}$ Both language versions were published by the government. “上手登據及山林原野之地契”, see Li Wenliang "Diguo de shanlin: Rizhi shiqi Taiwan shanlin zhengceshi yanjiu" [The Empire's forest: a research on the history of Taiwan forest policies during the Japanese period] (PhD diss, NTU, 2001), at 28, note 20.

${ }^{63} \mathrm{Cl} 2$.

${ }^{64} \mathrm{Cl} 3$.

65 山地取締規則, Rule (Furei 府令, executive decree) No 72, 1898.
} 
the mountain areas or to contract with the aborigines regarding use of the land, unless otherwise permitted by regulations or the Governor-General. ${ }^{66}$ The Ordinance regulated not only forest land, but also forests. It had been customary under the Qing that the Chinese contracted with the aborigines for rights to extract resources from the forest, such as timber. In responding to a query from the Hengchun Administrative Branch (banwushu 辦務署) as to whether such situations were governed by the Ordinance, the Tainan County Magistrate (zhishi 知事) firmly asserted that the forest belonged to the government and the situations were governed by the Ordinance. ${ }^{67}$

The declaration of ownership over unreclaimed land by the colonial government was fundamentally different from the Qing government's treatment of "wasteland" as government land. The Qing government's title over wasteland was in effect an administrative power rather than a proprietary right, as demonstrated in Chapter 3 . In contrast, the Japanese administration claimed property rights over all forest and unreclaimed land. In 1896 the Sōtokufu made ordinances and rules to lease forest land and sell forest resources, although the actual lease and sale were limited to land and resources in the regular administrative districts and did not extend to the mountain territories. ${ }^{68}$

In summary, soon after annexation the government asserted proprietary ownership over all wasteland in Taiwan. It took control of the wasteland in the regular administrative districts and started to profit from the land and the resources. Before the mountain aborigines were subjugated, the government could not actually possess the forest land in the aboriginal territory, but it legislated to prevent Han settlers and acculturated aborigines from using the land or having any contractual relationships with the aborigines. No legal justification was provided for the assertion of ownership, but the underlying assumption was that the aborigines did not have property rights over the forest and unreclaimed land. This was

\footnotetext{
66 關於佔有山地之律令, Ordinance No 7, 1900, in Xingzheng zhigao, above n 28, vol 1, at 125.

${ }^{67}$ Although the magistrate allowed the customary practice to continue for the time being because of difficulties in implementation. See ibid, at 127.

${ }^{68} \mathrm{Li}$, above n 62, at 112-115.
} 
made explicit in the 1900s when the government was ready to take control of the mountain territories.

\section{The aborigines' ability to own land}

To justify the government's preconceived plan to control the aboriginal territories, the government argued that the aborigines did not have legal ability to own land, implying the view that the land was terra nullius.

Soon after the annexation, the editorial of Japan's most influential newspaper, Jiji shinpō, suggested that "in order to pacify the island and develop the rich resources with the hands of our Japanese people, the goal of managing Taiwan should focus solely on the land while ignoring the natives", and called for the authority to "[focus] on the land while ignoring the islanders ... based on the notion of no-man's island". ${ }^{69}$ Such was the conviction of the Japanese elite.

This was exactly the stance of Japanese officials. A legal affairs advisor stressed in a report to the Sotokufu that the principal issue respecting the mountains and the mountain aborigines was land, as did a treatise by a judge of the Appellate Court of Taiwan. ${ }^{70}$ As legal specialists, both set out to argue why the ownership over the mountains rested with the government, not the tens of thousands of aborigines who occupied the mountain territories.

The first argument was that the mountain aborigines did not have legal personality. According to the Sōtokufu, even though the mountain aborigines could be recognised as human in biological and sociological terms, they were merely animals in terms of international law. ${ }^{71}$ Backtracking from Japan's 1874 argument that the Qing did not have sovereignty over the mountains, Japanese officials argued that since the Qing ceded the whole of Taiwan to Japan, Japan had sovereignty over the aboriginal territory. The

\footnotetext{
${ }^{69}$ The editorials of Jiji Shinpō of 14 August 1895 and 31 July 1896, as quoted in Chang Lung-Chih "From Island Frontier to Imperial Colony: Qing and Japanese Sovereignty Debates and Territorial Projects in Taiwan, 1874-1906" (PhD diss, Harvard University, 2003), at 166.

${ }^{70}$ See the report and the treatise in Xingzheng zhigao, above n 28, vol 1, at 149 and 741-744 respectively.

71 At 150 .
} 
aborigines lived on the government's land, but did not submit to the government's authority. Because legal rights were not inherent but were conferred by law, the mountain aborigines, who did not have a political organisation to confer legal rights and were not granted legal rights by the government, could not enjoy property ownership. ${ }^{72}$ The conclusion was that the aborigines' occupation of the land in the mountains was factual, but not legal, and the land belonged to the government. ${ }^{73}$

It appears that expediency and colonial interest were the driving force for the above arguments. Japan followed the mechanism of Western expansion without the debates that occurred in the West. The legal arguments justifying the government's rights over the aboriginal territories were put forward in the early 1900s, many years after the government's declaration of ownership over all wasteland. The arguments were put forward at that specific time to justify the government's action in aboriginal management (fanzheng 蕃政, J. bansei), the objective of which being to take control of the land.

\section{Aboriginal management}

Although in theory the colonial government disregarded the mountain aborigines, in practice it could not ignore those aborigines who formed strong obstacles against the government's mountain enterprises. The government several times stressed that the purpose of aboriginal management was to develop aboriginal land, and that the development of aboriginal land was dependant on good management of the aborigines. ${ }^{74}$ As the first Chief of the Civil Administration, Mizuno Jun, put it, camphor manufacture, forest management, land reclamation, agricultural outputs, mining, and even the settlement of Japanese migrants, were all dependent on successful management of the aborigines. ${ }^{75} \mathrm{It}$ was in terms of exploitation that the Japanese government recognised the importance of bringing the mountain aborigines under control.

\footnotetext{
72 At 152 and 741.

73 At 153.

${ }^{74}$ For example, see Wen Taiwan fanzheng zhi, above ch 3 n 33, at 629, 646 and 694.

${ }^{75}$ Xingzheng zhigao, above n 28, vol 1, at 3; Wen, ibid, at 630.
} 
The focus and strategy on aboriginal management shifted during the colonial rule. ${ }^{76}$ In the first few years of the Japanese rule, the government was preoccupied by the Chinese guerrillas who opposed Japanese occupation of Taiwan. The policy towards the aborigines was mainly to conciliate. As such the government retained some of the late Qing institutions and avoided provoking the aborigines. ${ }^{77}$ The government also invested in collecting information about the aboriginal peoples, their land and the resources, which essentially prepared for later action. This was a period when the government consolidated its control over the island and took a pragmatic approach towards the mountain aborigines.

Beginning in 1903, the government began to implement stricter and more coercive policies. It first extended the boundary guard lines, which had existed since the Qing time. The intention was to expand the area of government control and to restrict the aborigines' living space. ${ }^{78}$ This was fundamentally different from the Qing's purpose which was to segregate settlers and aborigines, to eliminate interaction and ultimately to reduce conflicts. By 1904 the guard lines were 480 kilometres long, an increase from about 80 kilometres at the end of the Qing rule. ${ }^{79}$ The number of guards was also increased from about 1,300 in 1898 to over 4,500 in $1905 .{ }^{80}$ The $5^{\text {th }}$ Governor-General, Sakuma Samata (1906-1914), launched a “five-year plan on aboriginal management” (lifan wunian jihua 理蕃五年計劃) for the period of 1910-1914 (Meiji 43-47). Military attacks and raids were carried out against the aborigines. ${ }^{81}$ During this period the guard lines continued to function, and landmines and electrified fences were used to control and force submission of the aborigines. ${ }^{82}$

The struggle between the government and the aborigines continued, but with the government gaining overwhelming advantage, the electrified fences were abolished in

\footnotetext{
${ }^{76}$ See Wen, ibid, for an overview of the Japanese government's management of the aborigines. For a more recent discussion, see Fujii Shizue Rizhi shiqi Taiwan zongdufu lifan zhengce [The aboriginal management policies of the Taiwan Sōtokufu during the Japanese period] (Wenyingtang, Taipei, 1997), which focuses on the period 1895-1915.

${ }^{77}$ Xingzheng zhigao, above $\mathrm{n} 28$, vol 2A, at 5.

78 Wen, above n 74, at 693.

79 Takekoshi, above n 28, at 214.

${ }^{80}$ Wen, above $\mathrm{n} 74$, at 702 .

${ }^{81}$ Xingzheng zhigao, above n 28, vol 2A, at 5. For Sakuma's aboriginal management actions, see ibid, at 747819.

${ }^{82}$ Wen, ibid, at 709.
} 
1924. ${ }^{83}$ The Musha Incident (wushe shijian 露社事件) of 1930 (Shōwa 5), where the aboriginal group of Seediq rebelled against the government and which resulted in the death of over 900 aborigines following the government's retaliation, prompted the Sōtokufu to re-evaluate its aboriginal policies and to focus more on conciliating the aborigines than on military campaigns and coercion. ${ }^{84}$ The focus was yet again shifted during the World War II, when the government tried to assimilate the aborigines and make them loyal subjects.

In summary, Japan followed Western examples in its colonisation of Taiwan and adopted legal instruments and international law doctrines in managing or justifying its management of the colony, especially the mountain territories. Possibly because the colonial theories and practices were a direct transplantation from the West, as opposed to being developed through experiments and debates, Japan's application of the practices were swift, forceful and directly linked to the objective of exploitation. In particular, the shifting strategies of aboriginal management coincided with the government's shifting focus on land projects, which started from agricultural lands in the western plains, progressed to the forest and unreclaimed lands in the regular administrative districts, and finally extended to the aboriginal territories once they were brought under control.

\section{Land Reform: Agricultural Land}

The colonial government's reform of land tenure in Taiwan started soon after annexation. The degrees of settler occupation, the levels of land development, the extension of government control and the types of available resources differed regarding land in the plains and the mountain areas, and in the regular administrative districts and the special administrative districts. The government used different methods to reform land tenure in different areas and at different stages. The government methodically dealt with the reform, starting from agricultural land, progressing to wasteland in the regular administrative districts, and finally to forestland in the special administrative districts.

\footnotetext{
${ }^{83}$ At 715.

${ }^{84}$ At $868-882$.
} 
Before each reform, the government thoroughly surveyed the land. In addition, extensive surveys and investigations about the tenure, the people and their customary practices were carried out as part of the colonial governance. The government also sponsored anthropological study about the Taiwanese aborigines, including their social organisations, customs and laws, and languages. In 1901, an "Old Customs Investigation Committee" (Kyūkan chōsakai 舊慣調查會) was established for the purposes of better understanding the colony and the colonised. During its 18 years of mission till 1919, the Committee produced three investigation reports (nine volumes in total), plus a comprehensive work on the private law (essentially Chinese customary law) of Taiwan, another on the administrative law of the Qing state, and a number of reports on the aborigines. ${ }^{85}$ As a "latecomer" among the colonial powers and having studied other colonial experiences, Japan well understood the importance of "scientific colonial knowledge" to good governance. ${ }^{86}$ The land surveys and tenure reforms were one example that thorough knowledge led to successful colonial administration.

This Part examines the reform of agricultural land, and Part IV discusses the projects concerning the forest land.

When Japan annexed Taiwan, the western plains were well-established farms. As discussed earlier, the Chinese customary practice of land tenure was sophisticated, but very imprecise and flexible. This was inconsistent with Japan's newly modernised land law regime. The colonial government imported Western property law, and systematically investigated land and land rights, tidied up the large rent system and established a land register. The reform modernised land tenure in Taiwan, ultimately severed the nominal and last link the acculturated aborigines had with their land, and facilitated Japanese acquisition of and investment in land.

\footnotetext{
${ }^{85} \mathrm{Wu}$ Wen-hsing "Jingdu diguo daxue yu Taiwan jiuguan diaocha" [Kyoto Imperial University and the investigation of old customs in Taiwan] (2007) 1 Shida Taiwanshi xuebao 29, at 30. Also see Timothy Y Tsu "Japanese Colonialism and the Investigation of Taiwanese 'Old Customs" in van Bremen and Shimizu (eds) Anthropology and Colonialism in Asia and Oceania, above ch $1 \mathrm{n}$ 35, at 197.

${ }^{86}$ Yao "The Japanese Colonial State and Its Form of Knowledge in Taiwan”, above ch 1 n 35, at 42 and 45.
} 


\section{A Land Cadastre}

The land cadastre was a process to gain comprehensive knowledge about the western plains, and a first step to reforming land tenure.

The Qing "fish scale" land register in Taiwan was partly missing or incomplete after the transition of power in $1895 .{ }^{87}$ Missing the basis for land tax collection, the Taiwan Land Tax Ordinance 1896 was made to stipulate that land tax was to be collected according to Qing precedents. ${ }^{88}$ Possibly because of the Chinese tradition that tax payment denoted yezhu rights, and the Taiwanese yezhu wished to establish their rights under the new regime, most yezhu paid the land tax, which totalled over 750,000 yen - not too much less than the government estimation of 879,086 yen. ${ }^{89}$ Nevertheless the government commenced the cadastre to collect precise information about the land.

In 1898 (Meiji 31), the Ordinance on Cadastre ${ }^{90}$ and the Taiwan Land Investigation Ordinance $^{91}$ were made to provide for extensive land surveys. Yezhu were required to report the details of their land for the cadastre, and those who did not report would have their land confiscated, in addition to a fine. ${ }^{92}$ The government then dispatched land surveyors to survey and verify each parcel of land. The land cadastre was completed in 1904, which recorded 777,850 jia of land surveyed. ${ }^{93}$ Scholars have compared this number with the late Qing survey record of 432,009 jia, and attributed the increase to the modern technology and equipment employed by the Japanese government. In fact the classification of land, the organisation of the survey, and the recording and reporting of the survey result by the Japanese administration were a comprehensive modern process. These all contributed to the increase and the two numbers cannot be compared at face value.

\footnotetext{
${ }^{87}$ Cheng jia-ying Taiwan tudi zhidu kaocha baogaoshu [A report on the Taiwan land tenure, 1914] (TWWX 184), at 22 .

88 臺灣地租規則, Ordinance No 5, cl 1.

${ }^{89}$ Cheng, above n 87, at 23.

90 地籍規則 Ordinance No 13, 1898.

91 臺灣土地調查規則 Ordinance No 14, 1898.

92 Cls 1 and 7.

${ }^{93}$ Sheng, Wang and Gao Taiwan shi, above ch 2 n 89, at 517.
} 
To begin with, the land survey was part of the extensive investigation of the colony, quite different from the late Qing survey which was directed at taxable land. The Ordinance on Cadastre classified land into six categories, including traditional Chinese productive land such as farm land and fish ponds; other productive land that the Qing government never regulated, such as forest and pasture land; and other land such as house sites, parks, railroad, rivers and river banks, other water channels, and miscellaneous land. ${ }^{94}$ The classification encompassed every possible type of land, and the survey only excluded roads, rivers and river banks, other water channels, land used for sewerage systems, and those forest and unreclaimed land that were deemed unnecessary for survey at that stage. ${ }^{95}$ Therefore the purpose of the survey extended beyond land tax to thorough collection of information on land.

After the survey, the government decided that only farm land and fish ponds were taxable, and these amounted to 633,065 jia. ${ }^{96}$ The number was still significantly higher than the late Qing survey result of 432,009 jia. At least three reasons could be attributed to the difference. First, the Qing statistics did not include official estates and fish ponds. ${ }^{97}$ Secondly, new lands were reclaimed between the two surveys. Thirdly, the Japanese survey employed modern technology such as trigonometrical and topographical methods which the late Qing survey could not match. Therefore the survey statistics were the result of different administrative methodologies, of which technological difference was just one aspect.

The survey was carried out by the Temporary Land Survey Bureau of Taiwan (Taiwan linshi tudi diaochaju 臺灣臨時土地調查局), which employed over 1,200 personnel at its busiest period in 1903 (Meiji 32), and investigated 1,647,374 parcels of land in total. ${ }^{98} \mathrm{~A}$ Land Survey Committee (Tudi diaocha weiyuanhui 土地調查委員會) was established in each sub-prefecture (ting 廳) to determine disputes about land titles, boundaries and land

\footnotetext{
94 Ordinance on Cadastre $1898, \mathrm{cl} 1$.

${ }^{95}$ Cheng, above n 87, at 28.

96 At 64 and 69.

${ }^{97}$ Official estates, which amounted to 15,352 jia, were recorded separately. Fish ponds were not surveyed. See Liu Zhuangsugong zouyi, above ch 2 n 129, at 318 and 322.

${ }^{98}$ Cheng, above n 87 , at 40 and 49.
} 
categories. ${ }^{99}$ The Committee was led by the local administrative chief, and consisted of six members appointed by the chief. ${ }^{100}$ While the Committee functioned as a special judicial body, the Land Survey Bureau was the executive body of the survey project. This model was borrowed from German practice. ${ }^{101}$

Appeals against the Committee's decision could be made to the Land Survey High Committee (Gaodeng tudi diaocha weiyuanhui 高等土地調查委員會), whose decisions were final. ${ }^{102}$ The High Committee consisted of three judges of Taiwan, three high ranking officials in the Sōtokufu, and three other people recommended by the Minister of Home Affairs for appointment by the Prime Minister. ${ }^{103}$ Disputes usually centred on boundaries or titles. In particular, because the late Qing reform did not completely exclude large rent holders from registering as yezhu, 961 title disputes between large rent holders and small rent holders were reported. ${ }^{104}$ In total 457 cases, concerning 4,007 parcels of land, or 2.4\%o of the total investigated land, were heard by the High Committee. ${ }^{105}$ The low percentage of appeals could be because of the accuracy of the decisions by the Land Survey Bureau, ${ }^{106}$ and their successful mediation of disputes which prevented disputes from reaching the Committee. ${ }^{107}$ It may also indicate the relatively low level of disputes about land titles under the Chinese customary system, which could operate well among people who observed the same norms, but would not have suited Japanese migrants who had come from a different legal background. ${ }^{108}$

\footnotetext{
99 Taiwan Land Investigation Ordinance 1898, cl 5.

${ }^{100}$ Rules on the Local Land Survey Committee 1898 (Furei No 92), recorded in Cheng, above n 87, at 3940 .

101 At 38 .

${ }^{102}$ Land Survey High Committee Ordinance (高等土地調查委員會規則), Ordinance No 15, 1898, cls 1 and 4. ${ }^{103} \mathrm{Cl} 2$.

104 Zhou Mao-chun "Rizhi chuqi Taiwan tudi diaocha zhi yanjiu (1898-1905)" [A research on the land survey during the early Japanese period, 1898-1905] (Masters thesis, National Taiwan Normal University, 2011), at 62.

105 Cheng, above $\mathrm{n} 87$, at 40 .

106 Zhou, above n 104, at 64.

107 Cheng, above n 87, at 41.

108 See Zhou, above n 104, at 62, where the author notes that one type of disputes was caused by different understandings about customary yezhu rights between the native and the Japanese parties.
} 
The survey of land in the western plains took seven years to complete (1898-1904). The survey technologies, the mechanism used to ascertain land titles and the legal instruments establishing the mechanisms all followed modern methods. After obtaining thorough knowledge about the land and ascertaining rights, the government proceeded to abolish large rent rights, with the purpose of simplifying the land ownership system and reforming land tax.

\section{B Land Tax Reform}

\section{Abolition of large rent rights}

Before reforming land tax, the Sōtokufu first abolished large rent rights. ${ }^{109}$ In Taiwan about $60 \%$ of agricultural land was subject to large rent. ${ }^{110}$ The late Qing land tax reform had been designed to simplify the two-tier land ownership system through abolishing large rent rights. Opposed by large rent owners, Governor Liu shifted tax responsibility to small rent owners who became registered yezhu, and allowed large rent owners to continue receiving $60 \%$ of the large rent without any obligations. The reform was thus incomplete, and large rent rights were not abolished until the Japanese period.

To further clarify land titles, in 1903 the Ordinance on Ascertaining Large Rent Rights was published. ${ }^{111}$ This Ordinance required recording and publishing of large rent right details, including information on right holders, location and registered numbers of land, and the annual amount of large rent. ${ }^{112}$ Concerned parties could request correction of the records within 90 days of the publication. ${ }^{113}$ No new large rent rights or increase of rent was permitted after the coming into effect of this Ordinance. ${ }^{114}$

\footnotetext{
${ }^{109}$ See above ch 4 for discussion of large rent rights, and ch 5 Part IV for the late Qing reform of large rent rights.

${ }^{110}$ Cheng, above n 87, at 57.

111 關於大租權確定之件, Ordinance No 9, 1903.

${ }^{112} \mathrm{Cls} 2$ and 3. See the Ordinance in Gaichi hōseishi [Legislation of the colonies] (Ministry of Foreign Affairs, Tokyo, 1990). A Chinese version is quoted in Yen and Yang Yuanzhu minzu tudi zhidu yu jingji fazhan, above "Introduction" n 49, at 177-178.

${ }^{113} \mathrm{Cl} 4$.

${ }^{114} \mathrm{Cl} 12$.
} 
The ascertainment of large rent rights was followed by the Ordinance on Reforming Large Rent Rights 1904. ${ }^{115}$ This Ordinance abolished all ascertained large rent rights. The government paid compensation. ${ }^{116}$ The calculation method for compensation was complex, but the end result was that the value of large rent rights per shi of grain was about three to five times of the grain value per shi, depending on the location. ${ }^{117}$ That is to say, the government paid three to five times the annual rent to buy off the large rent rights. In total over 36,000 large rent holders received over 3.78 million yen of compensation, for the value of 1.07 million yen of annual large rent. ${ }^{118}$ This means that on average each large rent holder received just over 100 yen of compensation, which was a very small amount. The compensation was paid in bond, which devalued to about $40-50 \%$ of its par value soon afterwards. ${ }^{119}$ Thus in true value large rent holders received compensation worth about 1.52.5 times of their annual rent, and lost their rent collection rights forever.

The process was carried out "peacefully" without strong reactions from large rent holders. ${ }^{120}$ There were two possible reasons for the lack of protest. Firstly, the calculation of compensation had taken into consideration the market price of large rent rights and the market price of grain (since large rents were paid in grain). ${ }^{121}$ The low compensation to some extent reflected the low value of large rent rights. In fact, one Japanese newspaper reported that the acculturated aborigines were pleased to sell their large rent rights to the government, because they had had difficulties collecting rent. ${ }^{122}$ Secondly, to ensure smooth implementation of the land reform, the Sōtokufu had built up a strong police system, which was ready for action against protests and was likely to have had intimidating effects on the large rent holders. ${ }^{123}$

\footnotetext{
115 關於大租權整理之件, Ordinance No 6, 1904.

$116 \mathrm{Cls} 1$ and 2 .

117 See the calculation in Cheng, above $\mathrm{n}$ 87, at 59-62. The island was divided into three areas, the north, the middle and the south, and the ratio was 5.351, 3.798 and 3.064 times respectively.

118 At 57 and 59.

${ }^{119} \mathrm{Ka}$ Japanese Colonialism in Taiwan, above "Introduction", n 47, at 60.

${ }^{120}$ Ibid.

${ }^{121}$ Cheng, above n 87, at 59-62.

122 Yen and Yang, above n 112, at 180.

${ }^{123} \mathrm{Ka}$, above n 119, at 59-60.
} 
Thus the abolition of large rent rights was provided by legal instruments, implemented with consideration of market values, and backed by police force. It was well prepared and was carried out in an orderly manner, quite different from the late Qing reform which was forced to change the initial plan because of protests from large rent holders and was heavily criticised, not always justly, by Governor Liu's rivals in the imperial Court. The reform was a complete modernisation of tenure. It simplified the land ownership system and paved the way for land tax reform.

\section{Land tax reform}

After the land ownership system was simplified, the government set new tax rates. Qing tax rates for private land in Taiwan simply followed that of a particular place in Fujian, and they did not change for nearly 200 years, until Governor Liu's reform. ${ }^{124}$ Liu's reform made adjustments to the tax calculation and collection. It simplified, but did not make fundamental changes, to the tax system. ${ }^{125}$ In contrast, the Japanese administration investigated land quality, productivity, small rent rates, price of rice and other agricultural products, values of the various currencies used in Taiwan, land price, loan interests and other factors relevant to agricultural productivity, before deciding on land categories and their respective tax rates. ${ }^{126}$ The tax reform was a complete reform based on thorough knowledge of the land, productivity, market and landlord-tenant relations.

The new tax rates were greatly increased. For most categories of land the new rates were about three times the Qing rates. ${ }^{127}$ Land tax revenue increased from 752,698 yen in 1896 to $2,975,736$ yen after the reform. ${ }^{128}$ However in effect small rent holders' burden of tax and fees for most categories of land reduced slightly, because during the Qing period small rent holders needed to pay large rent (which accounted for over half of the total payment obligation) and an additional supplementary tax. Therefore the reform of large rent rights and tax was a redistribution of benefits. With the increased tax revenue the government

\footnotetext{
${ }^{124}$ See Lian Taiwan tongshi, above ch 1 n 92, at 191-192 for lists of land tax rates during the Qing period.

125 See discussions and the new tax rates in ibid, at 177-178, and 192.

126 See Cheng, above n 87, at 64-66.

127 At 84-85, Table 8.

128 At 23 and 69.
} 
recovered the cost of large rent compensation in just over one year's time. A Chinese report sums it up by stating that "our country increased tax [burden] but tax [income] reduced; the Japanese reduced tax [burden] but tax [income] increased. The clumsiness or skilfulness of political manoeuvring ability are shown here." 129

The abolition of large rent rights and tax reform were the result of extensive data collection, careful calculation, and administration by law and police support. The reform simplified the land ownership system, but the benefits were not as great as might have been thought. After the reform, large rent holders, many of them aborigines, were excluded from the land tenure system with little compensation. The impact on small rent holders was in effect minimal, since they had already enjoyed yezhu rights before the reform, and their tax and fee burden changed little - although large rent was abolished, government tax was increased. The only beneficiary was the government, which received large rent holders' share as tax and increased revenue. To further modernise land tenure, the government proceeded to establish a land registration system.

\section{Land Registration}

As already stated, the Qing government maintained land registers, which were for tax purposes only and were often inaccurate or not up to date. The Sōtokufu introduced Western style land registration, which impacted on the substance of rights. The land registration system changed a number of times.

At first, Chinese customary land practice was allowed to continue. In 1898, the Ordinance on Civil, Commercial and Criminal Matters provided that all civil law and commercial law matters among the natives of Taiwan and Qing subjects were to be governed by existing laws, that is essentially by Chinese customary law. ${ }^{130}$ More specifically, all rights relating to land were to follow old customs (jiuguan 舊慣). ${ }^{131}$

\footnotetext{
129 At 69.

130 民事商事及刑事相關律令, Ordinance No 8, 1898, cl 1.

131 Ordinance on the Implementation of the Ordinance on Civil, Commercial and Criminal Matters 1898 (No

9) 民事商事及刑事相關律令施行規則, cl 1.
} 
Once all lands had been surveyed and titles had been clarified and simplified, the government was ready to introduce a new land registration system. After considering the Torrens registration system and the earlier experience in making Japan's Law on Real Estate Registration (1886 and 1899), ${ }^{132}$ the Taiwan Land Registration Ordinance was issued in $1905 .{ }^{133}$ Clause 1 specified that for all land recorded on the land survey ledger, the creation, transfer, alteration or disposal of the rights of yezhu, dian, tai and pugeng were invalid without registration, except succession of such rights which, if not registered, was recognised in law unless challenged by third parties. ${ }^{134}$ This was the first time that land registration became final proof of title, in contrast to the Qing period when customary practice prevailed, and titles were primarily determined by transaction deeds and supplemented by land registration and evidence of the surrounding facts.

The provision of title by registration was similar to the Torrens registration, but it was applied only to a limited extent, since clause 1 did not address existing rights. Rights of dian, tai, and pugeng that were created before the Ordinance came into effect had to be registered within one year after the Ordinance came into effect, otherwise they were not protected against third party claims. ${ }^{135}$ No similar requirement was made concerning existing yezhu rights. The provision, or lack of it, for the four kinds of rights implies that such existing rights were valid even without registration. ${ }^{136}$ As a result, in the first six months after the Ordinance came into effect, only about $2.5 \%$ of the $1,647,374$ parcels of land had yezhu rights registered, and the percentage increased to about $60 \%$ in $1911 .^{137}$ Therefore the new registration system focused on newly created, transferred, altered and disposed rights, and provided a mixed regime of new and old. This was probably a

\footnotetext{
${ }^{132}$ See Li "Taiwan tudi dengji zhidu bianqian zhi yanjiu", above "Introduction" n 50, at 51. Torrens is the system of title registration pioneered by Robert Richard Torrens in South Australia. It has long been used in Australia, New Zealand, and in a number of other countries.

133 臺灣土地登記規則, Ordinance No 3, 1905.

134 The Ordinance is available at http://catalog.digitalarchives.tw. See Li, above n 132, at 52-53 for relevant clauses in the Chinese language.

${ }^{135} \mathrm{Cl} 13$. Also see ibid, at 187.

136 See Wang, above n 50, at 151; Li, ibid, at 187.

${ }^{137} \mathrm{Li}$, ibid, at 189-190.
} 
pragmatic approach, seeking to accommodate the old customs while gradually modernising land tenure.

The Ordinance also went beyond land registration and specified that the rights of yezhu were to be equated with ownership, dian with pledge, tai with mortgage, and pugeng with tenancy, as defined in the Law on Real Estate Registration of Japan. ${ }^{138}$ Although the customary concepts of those rights were analogous to the respective Western property law concepts as introduced by Japan, the customary concepts were much less defined and had wide-ranging applications; the Western concepts were defined and clear-cut. Hence the equation of the two sets of concepts in effect changed the substance of the rights.

With the coming into effect of the 1921 "Law Concerning Laws and Regulations to be Enforced in Taiwan" in 1922, most substantive laws of Japan eventually became applicable in Taiwan. The application of the Civil Code of Japan in Taiwan from 1923 extended registrable rights to include rights of lease and easement. ${ }^{139}$ However, the fundamental change to the registration system was that the Civil Code provided that contracts gave effects to creation and transfer of real property rights, and registration of such rights provided only an additional protection against third parties. ${ }^{140}$ The difference between the system adopted in Taiwan earlier and the one applied in Japan, now extended to Taiwan, signifies the fact that Japan was still in the process of receiving different Western models and of modernising its own legal system.

In summary, although the Sōtokufu implemented a modern land registration system, it was a process of gradual change and a mixture of various norms, including Chinese customary law, the Torrens system, and Japanese land registration law which modelled on German and French examples. This reflects the pragmatic approach of the Japanese government, as well as the reality that Japan itself was still in the process of modernisation. Land registration to some extent consolidated land titles and other real property rights, and provided greater certainty and clarity to such rights.

\footnotetext{
138 Taiwan Land Registration Ordinance 1905, cls 4 and 5; Li, ibid, at 53.

${ }^{139} \mathrm{Li}$, ibid, at 191.

140 Ibid.
} 


\section{$D$ Effects}

As discussed in Chapter 5, following Liu Mingchuan's tax reform, hidden land was discovered and registered, small rent holders became yezhu, and aboriginal land in the plains areas became subject to registration and alienation. However Liu's reform did not impact much on the system of land ownership. Yezhu was still a concept primarily for tax purposes, land registration was still not final proof of title, large rent owners were still a class within the land tenure system and in some cases remained the registered yezhu, and land transactions were still carried out in the old format. Liu's reform prepared the ground for the Japanese land reform, but it was not essential for the Japanese reform. The two reforms were of different nature - Liu's reform made adjustments to the existing system, while the Japanese reform was a thorough modernising process.

The Japanese administration implemented a modernising system of land records, surveys and titles in much the same way as other colonial powers attempted to do elsewhere. The reforms were part of the westernisation of laws in Japan itself as well as in Taiwan. Scholarly views differ as to the extent to which these new systems benefited Taiwan.

One view sees the modernisation of the legal system, especially the property law regime, as "the best legacy of Japanese rule for the Taiwanese people". ${ }^{141}$ This view rests on the assumption that the modern law was better than customary law. It is true that the modern legal instruments were more precise and could provide visible and applicable rules for land title holders, but the actual benefits for all parties concerned - except the government and capital investors - are yet to be explored. As already mentioned, the elimination of large rent holder class was to the government's benefit alone. Further, the Chinese customary land tenure had developed over a millennium to suit practical needs. It accommodated various parties' rights and interests, and provided great flexibility for use of land.

${ }^{141}$ Wang, above n 50, at 183. 
A contrary view essentially argues that these changes served the interests of the colonial government and its own people, as they ultimately paved the way for the expropriation of land for the benefit of Japanese capital investment. ${ }^{142}$

This was also true. The Japanese government did intend to implant Japanese nationals as colonists, and had assisted them in acquiring land. In some cases the government, in particular the police force, coerced Chinese landowners to sell land to Japanese enterprises. ${ }^{143}$ By the late 1930s, while the Japanese population was about $5.4 \%$ of the total population, ${ }^{144}$ Japanese nationals held about $20-25 \%$ of the total cultivated land area, which was also of better quality than the others. ${ }^{145}$ The Japanese land owners accounted for the majority of large land holdings. In 1921, 112 Taiwanese land owners owned 42,000 jia of land, while 24 Japanese landowners owned about 51,500 jia, averaging 375 jia and 2,146 jia respectively. ${ }^{146}$ Monopolistic Japanese sugar companies owned $8.2 \%$ of total arable land. ${ }^{147}$ This indicates that the principal beneficiaries of the reforms were, and were intended to be, Japanese colonists.

The result was probably not as grave as might be thought. Thanks to the overwhelming number and percentage of Chinese farmers in the total population and their deep rooted land holding, Japanese colonists were not able to change the land holding on a large scale. Chinese farmers accounted for about $95 \%$ of the total population of over three million. In 1921 there were 423,278 land owners, and $84.58 \%$ of them owned less than 10 jia of land. ${ }^{148}$ The Japanese colonists, especially the sugar companies, found it easier to dominate the sugar export and influence the production through financing the farmers, rather than through controlling production by establishing their own plantations. ${ }^{149}$ In this regard,

\footnotetext{
142 Yao, above n 86, at 48-52.

143 Ching-chih Chen "Police and Community Control System in the Empire" in Myers and Peattie (eds), above n 42, 213, at 228; Samuel Pao-San Ho "Colonialism and Development: Korea, Taiwan and Kwantung" in Myers and Peattie (eds) 347, at 372.

${ }^{144}$ AJ Grajdanzev "Formosa (Taiwan) under Japanese Rule" (1942) 15 Pacific Affairs 311, at 316.

${ }^{145}$ Ho, above n 143, at 372 and 373. However, Ka, above n 119, at 101, notes that in 1939 Japanese nationals owned $13.2 \%$ of total arable land in Taiwan.

${ }^{146} \mathrm{Ka}$, ibid, at 146.

${ }^{147}$ At 101.

148 At 102, Table 15.

149 At 157-158.
} 
although the land reform facilitated establishment of plantations by Japanese colonists, it did not occur on large scale. Most land owners were not negatively affected in terms of land rights, although they might have been dominated in other ways.

Therefore, the land tenure reform in the settled areas was a process of accumulating colonial knowledge and of modernisation, and was intended to facilitate Japanese capital investments. However its effect was limited because the Chinese tenure was well established, and to a lesser extent, because Japan was experimenting with different models of land registration itself.

\section{Forest and Unreclaimed Land}

\section{A Investigation and Disposal of Forest Land}

The work on the land cadastre, large rent rights and land registration discussed in Part III did not extend to forest land or land in eastern Taiwan. ${ }^{150}$ After the agricultural land tenure reform was completed, the government then extended its attention to the forest land. Between 1910 and 1914 the government investigated forest and unreclaimed lands in the regular administrative districts, and in the next 10 years made detailed decisions regarding these lands. From 1925 to 1935 the government moved on to investigate and allocate lands in the aboriginal territory. As discussed in Part II, these categories of land had in 1895 been declared as government land as a matter of principle, unless valid written evidence of ownership could be produced. The work in the 1900s was to make actual use of this land.

The Investigation of Forest Land Ordinance $1911^{151}$ provided a procedure similar to that provided by the Land Investigation Ordinance 1898. Yezhu were to report their rights to the government, and a time limit of 60 days was imposed. ${ }^{152}$ Following yezhu claims, the government carried out a cadastral survey and ascertained the areas and right holders. ${ }^{153}$ At the conclusion of the survey in 1914, the government acquired ownership over 925,003 jia of forest land, including 172, 912 jia that was being used by private users who could

\footnotetext{
${ }^{150} \mathrm{Li}$, above $\mathrm{n} 132$, at 75.

151 林野調查規則, Ordinance No 7, 1911.

$152 \mathrm{Cl} 1$.

${ }^{153} \mathrm{Cl} 2$.
} 
not produce proof of ownership. ${ }^{154}$ Only 31,179 jia were recognised as privately owned. Apart from those that were already in use, the government set aside 398,540 jia of land which was to be leased to private enterprises, and kept 319,294 jia for security, public use or research purposes. ${ }^{155}$ In the end 266,398 jia were leased, and the government gained $5,892,398$ yen. ${ }^{156}$ This was the project directed at the forest and unreclaimed land in the regular administrative districts.

From 1925 to 1935 the government undertook the "forest planning project" (senlin jihua shiye 森林計劃事業), which focused on the use of the forest land in the aboriginal territory. The aboriginal territory occupied about 1.68 million jia of land, nearly two thirds of the total forest land area. ${ }^{157}$ Out of the 1.68 million jia, the majority was set aside for introducing private investment $(485,250$ jia) and government enterprises (existing and planned, in total 568,149 jia), as well as educational (117,091 jia) and security $(45,672 \mathrm{jia})$ uses. ${ }^{158}$ The mountain area enterprise (shandi shiye 山地事業) became a focus of government enterprises, which mostly was camphor manufacture, forestry and timber, but also included development of farm land and mining. ${ }^{159}$

While the government had earlier declared ownership over forest land and other unreclaimed land, the investigation prepared for promotion of forest enterprises and programmed use of land. About 90\% of forest and unreclaimed land, totalling over 2.26 million hectares, remained government-owned. The government extracted revenue from sale of forest products and licensing use of land, ${ }^{160}$ and provided private investors, mostly Japanese, business opportunities in the forest.

\footnotetext{
${ }^{154}$ See Horng Goang-jih "Linxue, ziben zhuyi yu bianqu tongzhi: Rizhi shiqi linye diaocha yu zhengli shiye de zai sikao" [Modern forestry, capitalism and frontier management: a reconsideration of the investigation and arrangement of the forest and unreclaimed land in Taiwan during the Japanese period) (2004) 11(2) Taiwanshi yanjiu 77, at 102 and 108. The users were allowed to continue to use those lands upon paying a fee to the government.

155 At 102 .

156 Ibid.

${ }^{157} \mathrm{Li}$, above $\mathrm{n} \mathrm{132}$, at 75; Yen and Yang, above n 112, at 206.

158 Yen and Yang, ibid.

${ }^{159}$ See the reports from each $s h \bar{u}$ (州 district) every year under the heading of "Mountain area enterprises" in Xingzheng zhigao, above n 28, vol 4.

160 See Horng, above n 154, at 134, Appendix 1.
} 


\section{$B$ Aboriginal Reserves and Relocation of the Aborigines}

The aborigines were occupying the land that the government planned to use. As part of its development programme, the government eventually established policies or practices regarding aboriginal reserves and relocation of the aborigines.

Relocation began in the early 1900s, but the peak period was between 1919 and $1934 .{ }^{161}$ The major purposes for relocating the aborigines were exploitation of resources and aboriginal management. To facilitate Japanese enterprises, aborigines were removed to smaller areas that did not impede forest development. A few examples show that as the forest enterprises developed and the government became more confident in its policies, the aborigines received decreasing land and monetary compensation.

For example, in 1922 (Taishō 11) the government relocated the aborigines in the Quchi 屈 尺 area because the land had been granted to a Japanese enterprise, the Mitsui 三井. The aborigines comprised 110 households and 546 people, and occupied over 10,200 jia of land. After relocation the government allocated to each aboriginal household an average of 7.5 jia of land, based on the estimation of five people per household. ${ }^{162}$ The government calculated that before relocation the aborigines had $236 \mathrm{jia}$ of cultivated land and 1,031 jia of fallow land, reduced to $164 \mathrm{jia}$ and 655 jia respectively after the relocation. The company was required to pay compensation at the rate of 150 yen per jia for cultivated land, and 50 yen per jia for fallow land that the aborigines lost. ${ }^{163}$ In the end the total payment was about 2,384 yen for cultivated land and 9,033 yen for fallow land, which converted to about 16 jia of cultivated land and $180 \mathrm{jia}$ fallow land. ${ }^{164}$ This means that 56 jia of cultivated land, 196 jia of fallow land, and 8,922 jia of other land were not compensated for. The government rejected the aborigines' conception that the land was their ancestral land. Officials informed the aborigines that all land belonged to the government, and that the reserved land for the aborigines was due to consideration for their livelihood. The

\footnotetext{
${ }^{161}$ Kondo Masami (trans Lin Shi-ting) Zonglizhan yu Taiwan: Riben zhimindi de bengkui [Total war and Taiwan: the collapse of the Japanese colony] (NTU, Taipei, 2014), at 272-276.

${ }^{162}$ Xingzheng zhigao, above $\mathrm{n} 28$, vol 4, at 305.

${ }^{163}$ At 306.

164 At 426.
} 
aborigines had to renounce any relationship with their ancestral land once they received compensation from the company for redundant land. ${ }^{165}$ Further, in the future if the company needed to use any of the allocated land for infrastructure purposes, the aborigines could not refuse, and the compensation was to be for crops only. ${ }^{166}$

Even so, the treatment that the Quchi aborigines received was better than other aborigines who were relocated. In another case, the government granted Mitsui 1,050 jia of land for development into wetland, tea farms and forestation. Forty-seven households lived on the land. ${ }^{167}$ The company's plan to provide each aboriginal household with 0.3 jia of wetland, 1 jia of dry land, 1.5 jia of fallow land, and 0.2 jia of tea land, in total 3 jia per household, was approved by the government. This amounted to 141 jia for the whole village. The compensation for fallow land was 5 yen per jia. ${ }^{168}$

By 1925 (Taishō 14), the colonial government tightened up the policies regarding relocation of aborigines. In a despatch to the Takao Shū (高雄州 Kaohsiung district) magistrate concerning the relocation of seven aboriginal villages, the Chief of the Police directed that the aborigines had to be relocated speedily, their land be opened up without obligations to the aborigines, and preferably that no compensation needed to be paid to the aborigines for their cultivated land. ${ }^{169}$

In the examples given above, allocation of land declined from $1.5 \mathrm{jia}$ per person or $7.5 \mathrm{jia}$ per household, to 3 jia per household, to an unspecified allocation. Compensation for the lost cultivated land also reduced, until at last the government decided not to require any compensation. The aborigines had to relinquish any further claims, and had only user rights over the reserved land. This shows the government's total disregard of the aboriginal land rights and livelihood, and its unconditional support of Japanese investors.

\footnotetext{
165 At 427.

166 At 428 .

167 At 309.

168 At 311-312. Both cases were reported in the 1922 section, but the first case was carried out in 1922, and the second case appeared to be work in progress.

169 At 630.
} 
In 1928, the government formally decided that reserved land for aborigines was to be based on three hectares per aborigine. ${ }^{170}$ The three-hectare allocation included 0.2 hectare for living space, 1.8 hectare for agriculture, 0.5 hectare for gathering wood and 0.5 hectare for livestock and other use. ${ }^{171}$ The government's investigation recorded over 80,000 aborigines, and accordingly 261,618 jia were set aside as aboriginal reserves, a small fraction of what the aborigines used to have. ${ }^{172}$ This number was an artificial calculation and reserves were marked on maps as a plan, rather than an actual allocation. ${ }^{173}$ In the implementation stage, some of the marked reserves were taken for forest enterprises, and in some cases it was found that the aboriginal population was bigger than estimated. ${ }^{174}$ The adjusted plan saw the average entitlement reduced to about 2.3 jia per person, but ranging from 1.47 to 3.03 jia in different areas. ${ }^{175}$ The plans served as guides when land of individual aboriginal villages was taken for forest enterprises and the aborigines needed to be relocated, but as will be seen, they were not always adhered to.

In 1930 the government formally launched the "mountain development investigation" (shandi kaifa diaocha 山地開發調查), which included both the investigation of aborigines themselves and the land needed for accommodating aborigines. Prior to the $1930 \mathrm{Wushe}$ Incident, most relocation was to areas within the aborigines' native territory. After the Incident, the government changed to relocating aborigines to the foothills, and on making the aborigines become subsistence farmers. ${ }^{176}$ The government invested in infrastructure for agriculture, such as irrigation systems. Even so, in 1933 the average agricultural land that each aborigine possessed amounted to $0.86 \mathrm{jia}$, ranging from as much as $1.3 \mathrm{jia}$ to as little as 0.18 jia per person for different aboriginal groups. ${ }^{177}$ Statistics for the period between 1935 and 1940 show little changes - ranging from an average of 1.09 jia to 0.95

\footnotetext{
170 Through a document “Relevant criteria for reserved areas of land for aboriginal use” (蕃人使用保留面 積標準有關要件). See Yen and Yang, above n 112, at 205.

171 At 205-206.

172 At 206. The number was adjusted at times and varied slightly in different records. For example, Kondo, above $n$ 161, at 270, records the number to be 243,665 hectare.

173 Yen and Yang, ibid, at 208-209.

174 At 208, 214 and 216.

175 At $212-213$.

${ }^{176}$ Lin "Jie/chonggou Taiwan yuanzhu minzu tudi zhengce", above "Introduction" n 2, at 77.

177 See Yen and Yang, above n 112, at 228, Table 4.13.
} 
jia in different years. This was far less than the planned 1.8 jia per person needed for agricultural purposes.

The intention of making aborigines engage in traditional style of intensive farming, apart from making them self-sufficient, was to transform them from vigorous mountain "savages" to submissive farmers and reduce the risks of resistance against the government. ${ }^{178}$ This was part of a programme to "civilise" the aborigines. More importantly, the relocation of the aborigines coincided with the development of the forest land, in particular the camphor industry. As the forest enterprises advanced, the aborigines were removed. ${ }^{179}$

The Japanese approach to aboriginal reserves was different from the late Qing's approach in a number of aspects. Firstly, the Japanese administration established aboriginal reserves as part of a land use plan and the reserves had small or no investment value. In contrast, the Qing allowed the aborigines to stay in their ancestral land. Secondly, the Japanese administration prescribed a strict quota of land for the aborigines, which was further diminished in the implementation, while the Qing's only requirement of the aborigines was that they open for reclamation the land that they could not reclaim themselves. Thirdly, the Japanese administration was involved in setting up compensation to the aborigines, while under the Qing it was up to the settlers and the aborigines to negotiate the price of land use. The Japanese administration directly controlled the planning and use of aboriginal land, supported Japanese forestry enterprises, and gained revenues from leasing forest land and selling forest products.

The aboriginal reserves and allocation of land were similar to the Indian reserves and the land allotment in the United States in the late $19^{\text {th }}$ and early $20^{\text {th }}$ centuries. ${ }^{180}$ This was because Japanese officials had studied the status of aborigines in various colonies around the world, and had decided that the approaches of the United States towards the American

\footnotetext{
178 At 212.

${ }^{179}$ See Lin Qiong-hua "Taiwan yuanzhumin tudi chanquan zhi yanbian, 1624-1945" [The evolution of the land rights of the Taiwanese aborigines, 1624-1945] (PhD diss, Soochow University, 1997), at 163-169.

${ }^{180}$ See David H Getches, Charles F Wilkinson and Robert Williams, Jr Cases and Materials on Federal Indian Law (4ed, West Publishing, St Paul, Minn, 1998), at 141-190 for Indian reserves and the land allotments in the United States.
} 
Indians were the most suitable for Japanese Taiwan. ${ }^{181}$ In the actual implementation, there were differences. In particular, the allocation of three jia to each mountain aborigine was on paper only, which was subject to change. The aborigines did not have ownership over the reserved land, ${ }^{182}$ and at least in some cases, the aborigines used the land collectively. ${ }^{183}$ This shows that Japan was skilful in applying Western models to local situations, making adjustments where it was beneficial and expedient for the colonial course.

\section{Pseudo-European Colonisation}

Following the Meiji Restoration, Japan rapidly modernised its own legal system, the purpose being to emulate the West. The same desire drove Japan's colonisation of Taiwan, since possession and exploitation of colonies were a European phenomenon of the time.

The legal theories Japan used to debate with the Qing during the Mudanshe Incident and to justify its occupation of the aboriginal territory were all Western in origin. Further, Japan adopted Western legal instruments in carrying out its colonial administration, especially legal instruments relating to land and property. Western advisors were consulted and Western experiences were studied. They were followed in both reforming the agricultural tenure and rearranging the forest land use, albeit with some adjustments to the local situation. These included German, French, British and United States models. Japan's "forms of knowledge" about the colony and the colonised even exceeded that of other colonial powers. ${ }^{184}$

If efficiency and economic growth were to be the only standards of judgement, Japan deserves to be commended for its success. Indeed a Japanese commentator of the early 1900s had celebrated Japan's ability in colonial administration. ${ }^{185}$ However this success was built on a foundation of total disregard of aboriginal land rights. Aboriginal land was

\footnotetext{
${ }^{181}$ See a 1918 report by an aboriginal affairs director (fanwu kezhang 番務課長) in Xingzheng zhigao, above n 28, vol 1, at 722-726.

182 Only when the aborigines resided in the regular administrative districts and paid land tax - a symbol of their civilisation - did their land rights become recognised. Ibid, at 146.

183 See Yen and Yang, above n 112, at 217.

${ }^{184}$ Yao, above $n$ 86, at 41.

185 Takekoshi, above n 28, at vii and 2. Also see the preface by Gotō Shimpei (Chief of Civil Administration of Taiwan, 1898-1906), at vi.
} 
rapidly taken by the government, and aborigines were relocated and confined to small areas of land, while Japanese investors entered the mountains to establish capitalist enterprises. In the plains area, the government's ability to rearrange land ownership was limited, but the land survey, land registration and tax reform changed land owners' substantive rights. It was no doubt a modernising process, but the main beneficiaries were the government and Japanese investors. The distinctiveness of the plains aborigines was eradicated and their last connection with the land was severed through the abolition of large rent rights.

It was not until the Japanese period that a modern form of colonisation occurred in Taiwan, and this was related to Japan's westernisation of its legal system. The different approaches Japan adopted towards the colonisation of the Ainu land, Ezo, before and after the Meiji Restoration lends support to this view. The Ainu land became a fief of the Matsumae clan in the 1500s, and was under the jurisdiction of the Matsumae clan for most of the time, but was under the Bakufu (the central government) direct control during 1799-1821 and 18541868. ${ }^{186}$ Before the 1868 Meiji Restoration, the treatment of the Japanese overlords to the Ainu was in many aspects similar to that of the Qing to the Taiwanese aborigines. The Matsumae government implemented a policy to segregate the merchant settlers ("contractors") and the Ainu, tried to prevent oppression of the Ainu by the contractors, and otherwise maintained a "non-interference" policy. ${ }^{187}$ The central government took direct control over Ezo for defence - because of threats of Russian penetration - rather than for exploitation. ${ }^{188}$ The government preferred a slow and gradual acculturation over forced assimilation, focusing on appeasement and guidance. ${ }^{189}$ After the Restoration, however, the Meiji government incorporated Ezo as Hokkaidō in 1869. A Hokkaidō Development Commission was established in the same year to investigate the land. A census was taken, and settlement was encouraged. ${ }^{190}$ In 1877, an ordinance was made to declare the Ainu land as state-owned, on the basis of terra nullius, ${ }^{191}$ and the government subsequently

\footnotetext{
186 Takakura The Ainu of Northern Japan, above "Introduction" n 61, at 9.

187 At 23, 38, and 44-47.

188 At $51-53$ and 81 .

189 At 55, 59 and 77.

${ }^{190}$ Mitsuharu Vincent Okada "The Plight of Ainu, Indigenous People of Japan” (2012) 1(1) Journal of Indigenous Social Development 1, at 5.

191 Tomonori Sugimoto “The Yellow Man's Burden: The Politics of Settler Colonialism in Hokkaidō and Taiwan" (MA thesis, University of California, San Diego, 2013), at 25.
} 
allocated the land to Japanese investors. ${ }^{192}$ Government policies after 1868 were consistent with the Japanese approaches in Taiwan, while policies before 1868 resembled Qing Taiwan policies in many aspects. This was because Japan had itself followed Chinese legal tradition until the 1868 legal reform. The effects of different types of legal system on colonisation is clear.

192 Okada, above n 190, at 5. 


\section{Conclusion: Land Tenure, Colonisation, and Legal Tradition}

This thesis set out to explore Qing policies towards land settlement and aboriginal land rights in Taiwan, and the effects of its legal tradition on policy-making, with a comparison from the Japanese period, situated within the theoretical framework of colonisation and colonialism. Chapter 1 depicted the spread of land settlement by Han Chinese till the end of the Qing administration; Chapter 2 traversed the three stages of Qing policies regarding land settlement in Taiwan; Chapter 3 analysed the Qing government's recognition and protection of aboriginal land rights in Taiwan; Chapter 4 considered the influence of Chinese customary land tenure on Taiwan's aboriginal land tenure; Chapter 5 explored the aborigines' action and reaction concerning the advancing Chinese settlement; and Chapter 6 examined Japanese colonial land policies.

This chapter draws together the findings of this thesis. Part I of this conclusion comments on the transformation of land tenure and aboriginal society in Taiwan, and reflects on the different styles of colonisation of the Qing and Japan. Part II considers the relationship between colonisation and the legal tradition.

\section{Transformation of Land Tenure and Aboriginal Society}

The transformation of land tenure and aboriginal society in Taiwan were incremental and limited in scale during the Qing period, but swift and complete during the Japanese period.

After over 200 years of Qing administration, the plains aborigines had lost their substantive land rights but still retained some large rent rights. They were mostly acculturated, but their distinctiveness as aborigines had not completely disappeared. The change of policy in 1874 did not bring much change to the mountains - neither to the people nor the land.

The main land tenure changes were brought about by Han settlers through private transactions and cultural influences. The government played very little part in the transformation of aboriginal land tenure. If anything, it delayed the transformation by restricting settlement and protecting aboriginal land rights. There was no requirement that aboriginal land tenure be changed in any way. Settler-aborigine land transactions attracted 
minimal government intervention, unless such transactions contradicted government protective policies or caused complaints from the aborigines.

There are some similarities of Qing Taiwan with other frontier societies. For example, in British colonies such as the United States, Australia and New Zealand, there was also land speculation and squatting, violence and chaos, and fraudulent dealings. ${ }^{1}$ Further, the native land title was recognised in New Zealand, Canada and part of the United States. ${ }^{2}$ What was different was government approaches towards frontier settlement and native title. In British colonies, governments were actively involved in extinguishing native titles, through various means such as Crown pre-emption, compulsory treaties with the indigenous peoples, legislation and the operation of Native Land Courts. ${ }^{3}$ Even where there appeared to be private land market in operation, the government influenced and regulated the market through the operation of law. ${ }^{4}$ This resulted in speedy land loss by the native peoples in British colonies. In New Zealand alone, within 20 years of the signing of the Treaty of Waitangi, nearly two-thirds of the Maori customary title had been extinguished, and the remaining was either extinguished or converted to new forms of tenure in subsequent decades. $^{5}$

In contrast, the Qing government protected aboriginal land rights, and was not involved in extinguishing Taiwanese aboriginal land titles. Qing recognition and protection of aboriginal land tenure was not as ineffective as scholars have believed. It is true that settlers found ways to evade government laws, and reclaimed the whole western plains notwithstanding government prohibition. However, government protective policies did slow down the spread of Han settlement, enabled many aborigines to remain as large rent holders for over 200 years, and excluded more than half of the whole island from settlement.

\footnotetext{
${ }^{1}$ See John C Weaver The Great Land Rush and the Making of the Modern World, 1659-1900 (McGillQueen's University Press, Montreal, 2003), ch 7; Boast Buying the Land, Selling the Land, above "Introduction" n 8, at 137 and 408-409.

2 Boast, ibid, at 25; Banner Possessing the Pacific, above "Introduction" n 8, at 60.

${ }^{3}$ For example, see Boast, ibid, 19-31 and ch 2; Banner, ibid, ch 3 and 7.

${ }^{4}$ Boast, ibid, at 448 .

5 At 26.
} 
The slow transformation of land tenure and the protective stance of the Qing government were quite different from Japan's disregard of aboriginal land rights, swift declaration of ownership over wasteland, methodical disposal of wasteland for the benefit of the government and Japanese investors, and vigorous reform of agricultural tenure. Under Japanese colonisation, the government was the only active actor in transforming the native land tenure. There was no frontier society as in the early contact years in the British colonies, or in Qing Taiwan. The government's role was absolute. This was because Japan was a late comer as a colonial power, and by which time colonial methods had been matured. Japan was able to draw on the experience of other colonial powers and chose the most advantageous methods.

Consistently with its minimal interference with land tenure, the Qing government rarely imposed cultural changes on aboriginal society. While the Western colonisers typically asserted "white man's burden" of civilising indigenous peoples, and Japan saw its assumption of civilising the Taiwanese aborigines as a contribution to the international community, the Qing did not share the same mission. Although officials anticipated sinicisation of the aborigines, the process was expected to be and was indeed slow; there was very little "missionary zeal" and officials did not actively pursue any cultural transformation. ${ }^{6}$ Even after the 1874 change of policy, the only requirement on the aborigines was to shave their heads, a symbol of submission that the Qing imposed upon all Chinese, and to restrict them from carrying weapons. This attitude helped the plains aborigines, although highly acculturated, to retain their separate identity, and also allowed the mountain aborigines to maintain their culture and autonomy.

Japan criticised the Qing for not civilising the aborigines. Chinese officials and literati preferred gradual transformation and often allowed one or two centuries for the aborigines to conform to Chinese civilisation, and for their land to be integrated into the empire. Japanese approaches were quite different. One Japanese politician dismissed the possibility of allowing a century to transform the aborigines, and argued this should be achieved

\footnotetext{
${ }^{6}$ This finding is consistent with Shepherd Statecarft and Political Economy on the Taiwan Frontier, above "Introduction" n 35, at 370 and 378.
} 
within 10 or so years. ${ }^{7}$ This did not preclude pacification and extermination if required. This was exactly what Japan did, with success.

The introductory chapter of this thesis considered the criteria for colonialism, which, among other things, require external manipulation and transformation of the aboriginal society and imposition of the colonisers' culture on the colonised. Qing policies on aboriginal land tenure and aboriginal culture show little manipulation, transformation and imposition by the government. Rather the manipulation, transformation and imposition were carried out by Han settlers. Colonialism was exercised by a people, rather than the government. Patrick Glenn has noted that Western expansion was often through the physical presence of settlers, and imperialism was often private rather than governmental in character. ${ }^{8}$ Qing colonisation of Taiwan certainly bore this characteristic.

The critical distinction is that, in the case of Western expansion, whether rooted in the Common Law or Civil Law, settlers went with government support and the ensuing extension of law, especially individualised property concepts $;{ }^{9}$ while in Qing Taiwan's case, the settlers did not enjoy government support, there was no conscious extension of formal law regarding private property matters, and the extension of law in other areas worked against the interests of the settlers.

Japan went a step further than many Western colonial states, in that the government initiated and organised the expansion and colonisation. This was because Japan drew on Western experience without having to go through stages of experiments.

\section{The Role of Legal Tradition}

Qing Taiwan policies were not unique in the Qing Empire. The restriction of Han migration, the segregation of Han settlers and aborigines, and the protection of aboriginal land rights were the same in Taiwan as at other Qing frontiers, such as Manchuria, Mongolia, Xinjiang and south-western China, although the timing and detailed operation varied depending on

\footnotetext{
7 Takekoshi Japanese Rule in Formosa, above "Introduction" n 6, at 230.

${ }^{8}$ Glenn Legal Traditions of the World, above "Introduction" n 9, at 273-274.

${ }^{9}$ At 273-274.
} 
strategic needs. Measures of protection, such as demarcating settlers' land and aboriginal land, requiring return of encroached or illegally alienated land, and regulating pledges and loans to aborigines, were also consistent. The policy change in 1874 was consistent with the policy to encourage land settlement whenever the government needed to people the frontier for defence purposes. The common factor in play was Chinese legal tradition, particularly the constitutional framework and the nature of law in Chinese tradition.

\section{A Aboriginal Land Rights}

The Chinese imperial constitutional framework was authoritarian. The empire was divided into the emperor (and his representatives), who had absolute authority, and the people, who were the "water" that either kept the "boat" of the imperial regime afloat or overturned it. This explains the government's preference for security and social stability over economic gains, and why Qing colonisation of Taiwan was basically non-exploitative. To achieve security and social stability, the government tried to maintain a power balance between different interest groups, which happened to be different ethnic groups in Qing Taiwan's case. Hence the government tended to suppress the perceived trouble-making Han settlers, and protected the disadvantaged aborigines.

In Western colonisation, there typically existed a bilateral relationship, that is, the European against the aborigines, the coloniser against the colonised. The government was the colonists' government and worked primarily for the colonists' interest. But in the case of Chinese expansion, the relationship was multi-dimensional. The emperor and his government presided over many different groups of people, and acted as the adjudicator between the colonists and the colonised. As a contributing factor, the Qing ruling house, itself a minority ruler, was inclined to suppress the Han and ally itself with the aborigines.

Traditional ideologies were also in play. The Confucian standard of a sage king required him to manage the frontier only for defensive purposes, and not for territorial expansion even less for exploitation. Further, traditional Chinese political thought favoured rule by moral example, and the reverse side of the absolute authority of the monarch was his moral obligation to treat the subjects as children. This dictated the paternalistic attitude of the emperor and officials towards the disadvantaged aborigines. 
However, the government's overriding consideration of security meant that when security was at stake, the government was prepared to sacrifice aboriginal rights. This was demonstrated in the incorporation of Gamalan due to pirate trouble, and the "opening the mountains" campaigns because of foreign threats. Protection of aboriginal land rights was a means to an end, the end being social stability and aboriginal livelihood.

\section{$B$ Land Tenure Changes}

The European idea of improvement to land valued investment of labour and capital in land and making the land productive, which was a powerful drive to the great land rush in the British colonies. ${ }^{10}$ The Chinese, having been an agrarian society for millennia, had a similar, if not stronger, love of cultivation of land. Some Qing officials in Taiwan saw the potential of vast wastelands becoming fine farms, and felt it a pity that the aborigines were not good farmers. Yet unlike the governments in the British colonies, the Qing government did not seek to change aboriginal land tenure or to "improve" and individualise land title. This was largely because of the property law regime in imperial China.

The Qing inherited the Chinese legal tradition where the formal law was used mainly in the political control over a society and to deal with criminal offences and official misdeeds. This meant that the government rarely regulated property law matters. The government's place in the land tenure system was to exercise public powers to grant land and charge a tax, and the "ownership" over wasteland did not amount to proprietary rights. The neglecting of property law matters meant that the government was not inclined to transform aboriginal land tenure. This was especially so for the Manchus because they did not have highly developed individualised land tenure themselves.

British colonisers pursued individualisation of title and transformation of aboriginal tenures out of a tradition to uphold individual land title back in the British Isles. ${ }^{11}$ Private land ownership was created and guaranteed by the state, and transformation of aboriginal land tenure laid in the hands of the government. The Chinese legal tradition, however, left

\footnotetext{
${ }^{10}$ See Weaver, above n 1, at 81-87 and 360. Also see Boast The Native Land Court vol 2, above ch 6 n 38, at 249-250.

${ }^{11}$ See Boast, above n 1, at 42 and 166.
} 
property law matters to Chinese customary practice, which was highly developed and dynamic. Private land ownership was well established, and land transactions had many flexible forms suitable for sophisticated commercial practices. Chinese customary practice was capable of transforming aboriginal land tenure without government involvement.

However the Chinese approach to property law could also mean that government attempts to protect aboriginal land tenure became ineffective. Most of the time the government played no role in regulating private land transactions. When the government did intervene, the methods were administrative and criminal in nature, and were not adequate to regulate the complex and dynamic practices among the people. The focus on cultivating good officials and the reluctance to make law also contributed to the inadequate response to land issues on the frontier.

Japan's style of colonisation and its land policies were also shaped by its legal traditions, especially after a rapid transition to legal modernity. Japan embarked on a modernising journey after the Meiji Restoration, and emulated the West in its acquisition of overseas colonies. The contrast between Japanese colonisation policies in Hokkaidō before and after the Meiji Restoration exemplifies the role of the legal system in the Japanese colonisation of Taiwan.

Apart from settler presence with government support, Western expansion had two other essential concepts, the notion of the state, and Western concepts of social organisation such as international law. ${ }^{12}$ These concepts were both missing in the Qing administration of Taiwan. In contrast, Japan used these two concepts extensively. Other Western legal instruments concerning property law were also applied, including land titling, registration and surveying.

The Qing administration of Taiwan proves that Chinese legal tradition was less likely to favour expansion and colonialism, or to impose Chinese culture, including land tenure, on indigenous peoples. This was a contrast to Western legal traditions. The Japanese colonisation of Taiwan, in effect an example of the imposition of Western styles of

${ }^{12}$ Glenn, above n 8, at 275-276. 
colonialism based on Western legal concepts, illustrates the importance of law in the colonising process. 


\section{Appendix 1: Land Deeds Quoted in Chapter 4}

(1)

具稟人沈紹宏, 為懇恩稟請發給告示開墾事。緣北路鹿野草荒埔原為鄭時左武駢將 軍舊荒管地一所, 甚為廣闊, 並無人請耕, 伏祈天臺批准宏著李嬰為管事, 招佃開 墾, 三年後輸納國課; 並乞天薹批發明示臺道, 開載四至, 付李嬰前往鹿野草草地 起蓋房屋，招佃開墾，永為世業，須至稟者。

今開四至, 東至大路及八撑溪, 西至龜佛山及茨, 南至抱竹及茨仔上, 北至溪茨。 康熙二十四年十月日。

墾荒, 現奉上令, 准速給照, 以便招佃及時料理; 候墾耕成熟之後, 照例起科, 照。

(原書第一行腐蝕, 字劃不存)賦足民事。據墾户詹嶨請打貓梅仔坑寮口荒埔十餘甲, 東至梅仔坑枋寮, 西至溪, 南至山, 北至中溪仔。據通事謝章等查明無騐, 合行給 墾。為此, 單給墾户詹陸即便前往所請界址內開墾輸課, 給此執照。

康熙四十七年四月日給。

本衙馬鳴山莊地, 內給出水田一甲二分, 付佃蔡贊亨前去開墾成田, 初年、二年一 九五抽, 三年依例每甲納經風搧淨乾好粟八石，車運到倉交納，不得短少，給批， 付照。

業主陳衙

雍正三年十月日給 
立招批業主簡琳芳, 有明贌南大肚番愛箸鲁霧莊園埔一所, 今有林生亭願自備牛工 種前來耕種，時約定每甲園埔願貼犁頭五十兩，以為開圳費用之資。其銀即日交訖; 其園埔隨即丈明十甲，界址分明，議定每甲佃首年納租栗五石滿，次年納租栗八石 霂, 以後每甲納租栗八石滿, 永遠定例。其租栗至收成之日, 務要重風搧淨, 車運 到鹿仔港交納, 不敢少欠誤課; 如有拖欠租粟者, 任從業主起耕招佃。倘日後奉害 縣主到莊清丈，俱要照甲納租，佃人不得異言; 但佃人要回家之日，先問明業主之 後, 任聽其脫替, 工本業主不得均分。委係二家甘願, 各無反悔, 恐口無憑, 立招 批是實。

$$
\begin{aligned}
& \text { 內分達皆弟名下園埔三甲銀一十五兩正。 } \\
& \text { 內分此沐姪名下園埔二甲銀一十五雨正。 } \\
& \text { 雍正七年（已西）正月日立招批。 }
\end{aligned}
$$

業主

知見人 陳紹慶

代筆人 林利壽

立招佃人業户李朝榮, 明買有大突青埔一所, 坐落土名巴劉巴來, 東至柳仔溝埤為 界, 西至大溝為界, 南至入社大車路為界, 北至黄邦傑厝後港為界, 四至明白。今 有招到李思仁、賴束、李祿亭、梁學俊等前來承贌開墾, 出得埔銀六十五兩正, 情 願自備牛犁方建筑坡圳, 前去耕墾, 永為已業。歷年所收花利照莊例一九五抽的, 及成田之日, 限定經丈八十五石霂班為一甲, 每一甲經租八石, 車運到港交納。二 比甘願, 日後不敢生端反悔, 增加減少, 亦不敢升合拖欠; 如有拖欠定額, 明官究 討。口恐無憑，立招佃一紙存照。

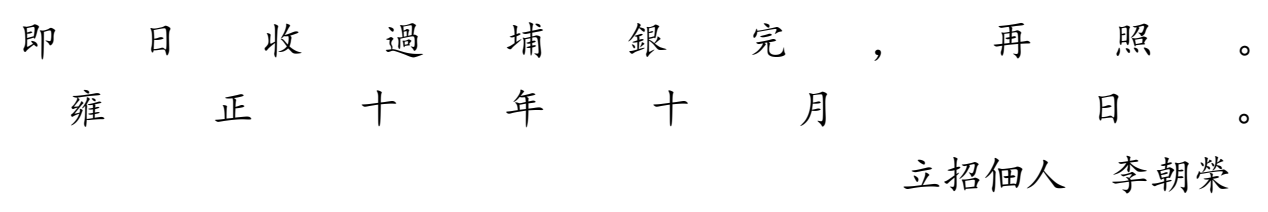


(6)

立合約大武郡社土官蛤肉等, 有草地一所, 北至水漆林為界, 西至吴宅往海豐路為 界, 東至本莊熟園, 南至溪為界; 四至明白。因課飭無征, 今招得丁作周前來出本 開筑坡圳, 以作水田。今當鄉保通事公議, 雍正元年起, 每年佃栗五十石斗, 系舊 斗, 番人到莊車運, 永遠定例, 日後不得聽人唆使生端等情。倘佃人有短少租栗, 以及為非等情，系丁作周之事，不千番人之事。此系二比甘願，不敢異言; 今欲有 憑，立合約為照

雍正元年八月日

知見葉伯選

張苑

立合約蛤肉

丁作周

代書人李士元

全立合約人下淡水社土官阿裡莫、教冊施也落等, 原有草地一所。自肆拾陸年因

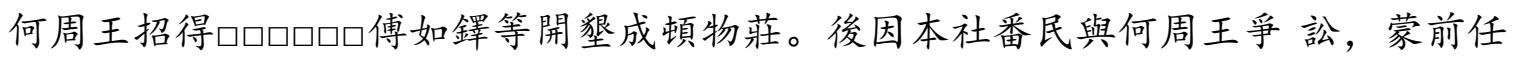
縣主宋審斷, 頓物莊租栗歸於番民完課。當日番佃面立合約, 其筑埤開圳費用工本

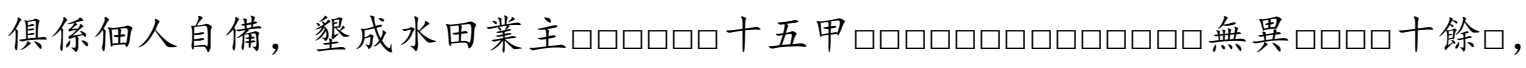
歷年每甲納租七石送社交含明白。茲因伍拾㺵年本社番齒益眾, 向佃議增租栗, 至控縣主李審斷, 加租武石 ${ }^{\prime} 00$ 案, 番佃雨相允服。茲今頓物莊, 各佃名下額租, 並審斷所加之租, 俱一足收, 但今本社眾番, 苦無應公, 仍向頓物莊各佃借過栗共

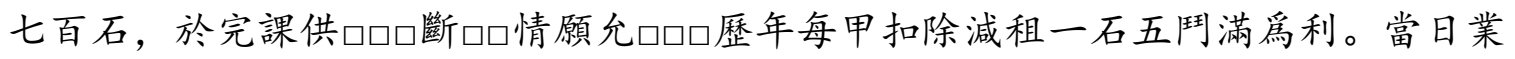
佃面議，每年每甲實收租栗七石五鬥滿，佃人車運本社交含，永鴬定例。其佃人日 後有別圖生業以及回唐者, 其田底聽憑佃人頂退, 抵還工本, 業主不得再生枝節。 (下略)

康熙陸拾年武月 全立合約下淡水社土官阿裡莫 (餘略) 
立典契字人下水仔莊陳周，有自己應份鬨分份下水田一段，址在旱溪底。大小三坻， 束至園茨，西至添生田，南至添生田，北至番叔田; 四至界址明白。今因乏銀別創， 先畫問房親人等不能承受, 外托中引就向與本宗陳玉麟出首承典, 當日三面議定時 值價銀一百五十大員正。其銀即日同中交收足訖; 其田隨即踏付銀主前去掌管起耕， 招佃耕作，年納大租穀一石，又水租四鬥。其田限自甲子年起，至甲戌年終，聽周 備足典契字內銀一足送還, 取回原契字; 如銀未備, 任從銀主耕作, 不得习難。保 此田係周應份塩分物業, 與房親人等無幹, 亦無重張典掛他人財物, 並無拖欠大租 及上手來歷交加不明等情; 如有此情, 周一力抵擋, 不幹銀主之事。此係二比甘願, 各無反悔, 口恐無憑, 立典契字一紙, 録書一紙, 共二紙, 付執為照, 行。

即日同中收過典字內銀一百五十大員正完足, 再照, 行。 其上手契連在別段, 難以開折, 再照。

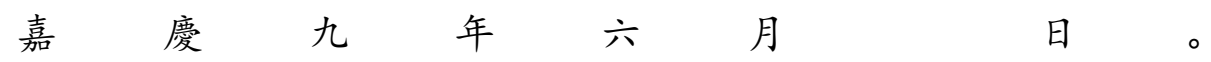

代筆人 (宗姪)希周 知見人 (胞兄) 起 為中人 葉圆 立典契字人 陳

(9)

立招耕給壓地契眉裹社番破難未說、乾昆未說, 同有承父䝒分熟園二坻相連, 坐落 土名舊眉社崙仔下，束至伯巴難未說為界，西至蒲旱及陳縣園為界，南至六萬胡及 小打晉巫仕園為界，北至車路及打晉巫仕園為界; 四至界址明白。經同通土三面丈 明三甲，歷年該带園租栗十二石满。今因離社䳆遠，無力耕作，先盡問本社內番親 不能承耕，外托中招引與漢人楊從官耕作，先收過給壓地銀四百大員正。銀即日同 中收訖; 園聽楊從官前去翻犁耕作二十年。番為業主, 民為佃户，歷年備租栗十二 石, 付番社運去, 不得短欠。限至已满, 未說原給壓地銀取回原契, 不得习難; 如 銀未還，付銀主再耕作，任從其便，不敢生端異言。保此園係巴難未說、乾昆未說 兄弟承兄物業, 並無叔兄弟姪爭執, 及重張交關不明等情; 如有不明等情, 巴難兄 弟自己出頭抵擋，不幹佃戶之事。今欲有憑，立招耕給佃契二紙，各執一紙，付執 為照。 
即日同中收過給佃銀四百大員正完足, 再照。 嘉 慶 三 年 再見伯巴難未說 知見母親投大夷

為中 $\square \square \square$
立招耕給壓地契番巴難未說 乾昆未說 
Appendix 2: "Land for Water Deed" 1723 quoted in Chapter 5

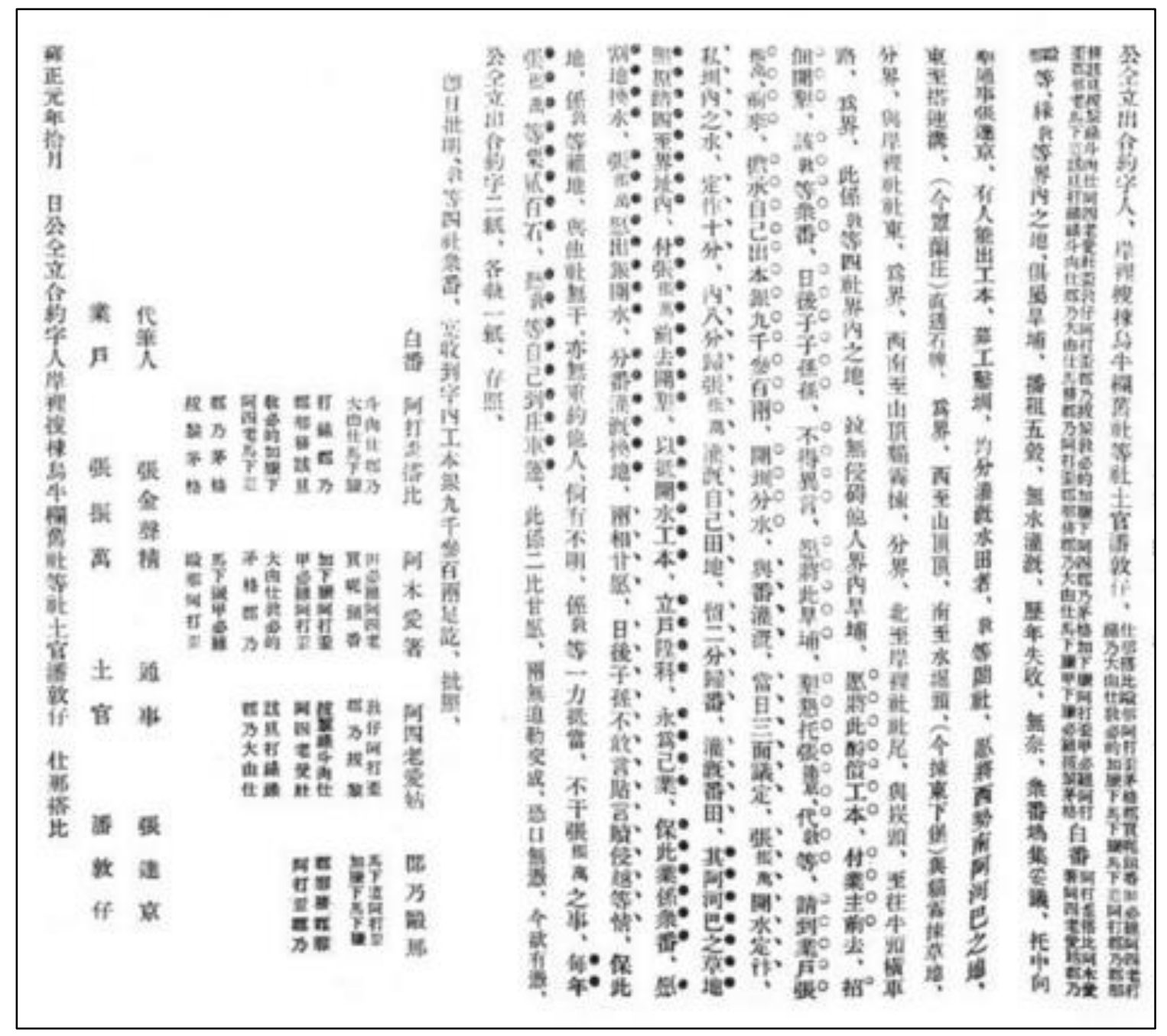




\section{Bibliography}

Abbreviation:

TWWX - Taiwan Wenxian Congkan 臺灣文獻叢刊 [Taiwan literature and documents collection] (Taiwan yinhang, Taipei, 1957-1975, 309 titles)

\section{Primary Sources}

\section{A Legislation}

1 Qing period

Fujian shengli 福建省例 [Regulations of Fujian Province] (TWWX 199)

Hubu zeli f部則例 [Regulations of the Ministry of Households, cir 1865] (Chinese Text Project, www.ctext.org)

Qinding Daqing huidian shili 欽定大清會典事例 [Imperially approved precedents of the Great Qing Institutes, 1886] (Chinese Text Project, www.ctext.org)

Qing huidian Taiwan shili 清會典薹灣事例 [Great Qing Institutes, precedents concerning Taiwan] (TWWX 226)

\section{Japanese period}

Gaichi hōseishi 外地法制志 [Legislation of the colonies] (Ministry of Foreign Affairs, Tokyo, 1990)

Investigation of Forest Land Ordinance 1911 (No 7) 林野調查規則

Land Survey High Committee Ordinance 1898 (No 15) 高等土地調查委員會規則

Ordinance on Civil, Commercial and Criminal Matters 1898 (No 8) 民事商事及刑事相關 律令 
Ordinance on Ascertaining Large Rent Rights 1903 (No 9) 關於大租權確定之件

Ordinance on Cadastre1898 (No 13) 地籍規則

Ordinance on Government-owned Forest Land and Camphor Manufacture 1895 (No 26) 公[官]有林野及樟腦製造業取締規則

Ordinance on Occupation of Land in the Mountain Areas 1900 (No 7) 關於佔有山地之律 令

Ordinance on Reforming Large Rent Rights 1904 (No 6) 關於大租權整理之件

Ordinance on the Implementation of the Ordinance on Civil, Commercial and Criminal Matters 1898 (No 9) 民事商事及刑事相關律令施行規則

Rules on Control of Aboriginal Territory 1898 (Furei No 72) 山地取締規則

Rules on the Local Land Survey Committee 1898 (Furei No 92) 地方土地調查委員會之 規則

Taiwan Land Investigation Ordinance1898 (No 14) 臺灣土地調查規則

Taiwan Land Registration Ordinance 1905 (No 3) 臺灣土地登記規則

Taiwan Land Tax Ordinance 1896 (No 5) 臺灣地租規則

Xu Guo-zhang (trans) 徐國章(譯) Taiwan zongdufu gongwen leizhuan: lüling shiliao huibian 臺灣總督府公文類纂律令史料彙編 [Official documents of the Taiwan Sōtokufu: legislation collection] (Taiwan Historica, Nantou, 2012) vol 1\&2

B Cases

1 Australia

Mabo v Queensland (No 2) [1992] HCA 23 
2 New Zealand

Ngati Apa v Attorney-General [2003] NZCA 117

C Collection of Land Deeds

Li, Paul Jen-kuei 李壬癸 Xingang wenshu yanjiu 新港文書研究 (Studies of Sinkang Manuscripts) (Academia Sinica, Taipei, 2010)

Liu Ze-min 劉澤民 Dajia dongxishe guwenshu 大甲東西社古文書 [Historic documents concerning the Dajia East and Dajia West villages] (Taiwan Historica, Nantou, 2003)

Liu Ze-min 劉澤民 Pingpu baishe guwenshu 平埔百社古文書 [Historic documents of a hundred plains aboriginal villages] (Taiwan Historica, Nantou, 2002)

Qingdai Taiwan dazu diaochashu 清代薹灣大租調查書 [Collection of large rent documents in Qing Taiwan] (TWWX 152)

Tung Yuan-Chao and Tseng Cheng-ming (eds) 童元昭, 曾振名 (編) Gamalan Xilaya guwensh $u$ 噶瑪蘭西拉雅古文書 [Historic documents of the aboriginal groups of Kavalan and Siraya] (NTU, Taipei, 1999)

D Other Primary Records

Chen Peigui 陳培桂 Danshui tingzhi 淡水廳志 [Gazetteer of Danshui Sub-Prefecture, 1871] (TWWX 172)

Chen Shujun 陳淑均 Gamalan tingzhi 噶瑪蘭廳志 [Gazetteer of Gamalan Sub-prefecture, 1852] (TWWX 160)

Chen Wenda 陳文達 Fengshan xianzhi 鳳山縣誌 [Gazetteer of Fengshan County, 1719] (TWWX 124)

Chen Wenda 陳文達 Taiwan xianzhi 薹灣縣誌 [Gazetteer of Taiwan County, 1720] (TWWX 103) 
Fan Xian 范咸 Chongxiu Taiwan fuzhi 重修臺灣府志 [Revised gazetteer of Taiwan Prefecture, 1747] (TWWX 105)

Fujian Taiwan zouzhe 福建臺灣奏摺 [Memorials on Taiwan] (TWWX 29)

Gao Gongqian 高拱乾 Taiwan fuzhi 薹灣府志 [Gazetteer of Taiwan Prefecture, 1694] (TWWX 65)

$\mathrm{Hu}$ Chuan 胡傳 Taidongzhou caifangce 臺東州採訪冊 [Draft gazetteer of Taidong Department, cir 1892-1895] (TWWX 81)

Huangchao wenxian tongkao 皇朝文獻通考 [Comprehensive collection of important documents of the Qing Dynasty, 1787]

Jiaxu gongdu chaocun 甲戌公牘鈔存 [Documents relating to the 1874 incident] (TWWX 39)

Jiang Yuying 蔣毓英 Taiwan fuzhi 臺灣府志 [Gazetteer of Taiwan Prefecture, cir 1689] (Taiwansheng wenxian weiyuanhui, Nantou, 1993)

Linshi Taiwan Jiuguan Diaochahui 臨時薹灣舊慣調查會 Taiwan sifa fulu cankaoshu 臺 灣私法附錄參考書 [Private law of Taiwan reference book] (Taipei, 1910)

Liu Liangbi 劉良璧 Chongxiu Fujian Taiwan fuzhi 重修福建㗌灣府志 [Revised gazetteer of Taiwan Prefecture, Fujian, 1741] (TWWX 74)

Liu Mingchuan fu Tai qianhou dang'an 劉銘傳撫臺前後檔案 [Historic documents before and after Liu Mingchuan's governorship in Taiwan] (TWWX 276)

Liu Mingchuan 劉銘傳 Liu Zhuangsugong zouyi 劉莊肅公奏議 [Memorials of Liu Mingchuan] (TWWX 27)

Qing Dezong shilu xuanji 清德宗實錄選輯 [Selected veritable records of the Guangxu Emperor] (TWWX 193) 
Qing Gaozong shilu xuanji 清高宗實錄選輯 [Selected veritable records of the Qianlong Emperor] (TWWX 186)

Qing Muzong shilu xuanji 清穆宗實錄選輯 [Selected veritable records of the Tongzhi Emperor] (TWWX 190)

Qing Renzong shilu xuanji 清仁宗實錄選輯 [Selected veritable records of the Jiaqing Emperor] (TWWX 187)

Qing Shengzu shilu xuanji 清聖祖實錄選輯 [Selected veritable records of the Kangxi Emperor] (TWWX 165)

Qing Shizong shilu xuanji 清世宗實錄選輯 [Selected veritable records of the Yongzheng Emperor] (TWWX167)

Qing Xuanzong shilu xuanji 清宣宗實錄選輯 [Selected veritable records of the Daoguang Emperor] (TWWX 188)

Riju shiqi yuanzhumin xingzheng zhigao 日据時期原住民行政志稿 [Administration of aborigines during the Japanese period, translation of Ribanshiko compiled by the Police Administration Bureau, Taiwan Sōtokufu, 4 vol] (Taiwansheng wenxian weiyuanhui, Nantou, 1997)

Tai'an huilu jiaji 臺案魚錄甲集 [Taiwan documents collection series A] (TWWX 31)

Tai'an huilu bingji 臺案累錄丙集 [Taiwan document collections series C] (TWWX 176)

Taiwan lifan guwenshu 臺灣理蕃古文書 [Historic documents concerning Taiwan aboriginal affairs] (Chengwen, Taipei, 1983)

Taiwan Shiliao Jicheng Bianji Weiyuanhui 臺灣史料集成編輯委員會 Ming Qing Taiwan dang'an huibian 明清臺灣檔案彙編 [Collection of Historic documents concerning Taiwan during the Ming and Qing Dynasties] (Yuanliu, Taipei, 2004-2009) 
Taiwan zongdufu dang'an zhongyiben 臺灣總督府檔案中譯本 [Chinese translation of the administrative files of the Taiwan Sōtokufu] (Taiwansheng wenxian weiyuanhui, Nantou, 1992)

Tongzhi Jiaxu ribing qin Tai shimo 同治甲戌日兵侵臺始末 [Documents on the 1874 Japanese invasion of Taiwan] (TWWX 38)

Tu Jishan 屠繼善 Hengchun xianzhi 恆春縣志 [Gazetteer of Hengchun County, 1894] (TWWX 75)

Wang Kaitai 王凱泰 Fujian Tongzhi Taiwanfu 福建通志臺灣府 [Gazetteer of Fujian, Taiwan Prefecture, 1871] (TWWX 84)

Wu Mi-cha (ed) 吴密察 Dan Xin dang'an 淡新檔案 [Administrative files of Danshui and Xinzhu Counties] (NTU, Taipei, 2006)

Yongzheng zhupi zouzhe 雍正硃批奏摺 [Memorials with rescripts of the Yongzheng Emperor] (TWWX 300)

Zhou Xi 周雪 Zhanghua xianzhi 彰化縣誌 [Gazetteer of Zhanghua County, 1830] (TWWX 156)

Zhou Yuanwen 周元文 Chongxiu Taiwan fuzhi 重修臺灣府志 [Revised gazetteer of Taiwan Prefecture, 1718] (TWWX 66)

Zhou Zhongxuan 周鐘瑄 Zhuluo xianzhi 諸羅縣誌 [Gazetteer of Zhuluo County, 1717] (TWWX141)

\section{Books}

\section{English}

Aldrich, Robert and John Connell The Last Colonies (Cambridge University Press, Cambridge, 1998) 
Andrade, Tonio How Taiwan Became Chinese: Dutch, Spanish and Han Colonization in the Seventeenth Century (Columbia University Press, New York, 2008)

Andrade, Tonio Lost Colony: The Untold Story of China's First Great Victory over the West (Princeton University Press, Princeton and Oxford, 2011)

Banner, Stuart Possessing the Pacific: Land, Settlers, and Indigenous People from Australia to Alaska (Harvard University Press, Cambridge (Mass), 2007)

Barclay, George W Colonial Development and Population in Taiwan (Princeton University Press, Princeton, 1954)

Benton, Lauren A Search for Sovereignty: Law and Geography in European Empires 14001900 (Cambridge University Press, Cambridge, 2010)

Blundell, David (ed) Austronesian Taiwan: Linguistics, History, Ethnology, Prehistory (Rev ed, Shung Ye Museum of Formosan Aborigines, Taipei; Phoebe A Hearst Museum of Anthropology, Berkeley, 2009)

Blust, Robert The Austronesian Languages (revised ed, ANU, Canberra, 2013)

Boast, Richard Buying the Land, Selling the Land: Governments and Maori Land in the North Island1865-1921 (Victoria University Press, Wellington, 2008)

Boast, Richard For the Good of the Natives: Land and Society in the Pacific 1860-1940 (manuscript)

Boast, Richard The Native Land Court vol 2: A historical study, cases and commentary 1888-1909 (Thomson Reuters, Wellington, 2015)

Bodde, Derk and Clarence Morris Law in Imperial China: Exemplified by 190 Ch'ing Dynasty Cases (Harvard University Press, Cambridge (Mass), 1967)

Borao Mateo, José Eugenio The Spanish Experience in Taiwan 1626-1642: The Baroque Ending of a Renaissance Endeavor (Hong Kong University Press, Hong Kong, 2009) 
Campbell, William Formosa under the Dutch (Kegan Paul, Trench, Trubner, London, 1903)

Chiu, Hsin-hui The Colonial "Civilizing Process" in Dutch Formosa, 1624-1662 (Brill, Leiden and Boston, 2008)

Cohn, Bernard S Colonialism and its Forms of Knowledge: The British in India (Princeton University Press, Princeton, 1996)

Cohen, Jerome Alan, R Randle Edwards and Fu-mei Chang Chen (eds) Essays on China's Legal Tradition (Princeton University Press, Princeton, 1980)

Davidson, James W The Island of Formosa: Past and Present (MacMillan, London and New York, 1903)

Dubs, Homer H (trans) The Works of Hsüntze (Confucius Publishing, Taipei, 1972)

Elliott, Mark C The Manchu Way: The eight banners and ethnic identity in late imperial China (Stanford University Press, Stanford, 2001)

Fairbank, John K (ed) The Cambridge History of China Volume 10: Late Ch'ing 18001911 Part One (Cambridge University Press, Cambridge, 1978)

Getches, David H, Charles F Wilkinson and Robert Williams, Jr Cases and Materials on Federal Indian Law (4ed, West Publishing, St Paul, Minn, 1998)

Giersch, C Patterson Asian Borderlands: The Transformation of Qing China's Yunnan Frontier (Harvard University Press, Cambridge (Mass) and London, 2006)

Glenn, H Patrick Legal Traditions of the World: Sustainable Diversity in Law (5ed, Oxford University Press, Oxford, 2014)

Guy, R Kent Qing Governors and Their Provinces: the evolution of territorial administration in China, 1644-1796 (University of Washington Press, Seattle, 2010)

Hostetler, Laura Qing Colonial Enterprise: Ethnography and Cartography in Early Modern China (University of Chicago Press, Chicago, 2001) 
House, Edward H The Japanese Expedition to Formosa (Tokyo, 1875)

Hung, Chien-Chao A History of Taiwan (Cerchio Iniziative Editoriali via Gambalunga, Rimini, 2000)

Huang, Pei Reorienting the Manchus: A Study of Sinicization, 1583-1795 (Cornell University, Ithaca, New York, 2011)

Hucker, Charles O A Dictionary of Official Titles in Imperial China (Stanford University Press, Stanford, 1985)

Jansen, Marius B (ed) The Cambridge History of Japan Volume 5: The Nineteenth Century (Cambridge University Press, Cambridge, 1989)

Ka Chih-Ming Japanese Colonialism in Taiwan: Land Tenure, Development, and Dependency: 1895-1945 (Westview Press, Colorado, 1998)

Kim, Hyung I Fundamental Legal Concepts of China and the West: A comparative study (Kennikat Press, New York, 1981)

Knapp, Ronald G (ed) China's Island Frontier: studies in the historical geography of Taiwan (University Press of Hawaii, Honolulu, 1980)

Le Gendre, Charles Is Aboriginal Formosa a Part of the Chinese Empire? An Unbiased Statement of the Question (Lane, Crawford \& Co, Shanghai, 1874)

Le Gendre, Charles W Reports on Amoy and the Island of Formosa (Government Printing Office, Washington, 1871)

Lee, Robert HG The Manchurian Frontier in Ch'ing History (Harvard University Press, Cambridge (Mass), 1970)

Liao, Ping-hui and David Der-wei Wang (eds) Taiwan under Japanese Colonial Rule, 1895-1945 (Columbia University Press, New York, 2006) 
Manser, Martin H (ed) Concise English-Chinese Chinese-English Dictionary (2ed, Oxford University Press, Oxford, 1999)

Mote, Frederick W Imperial China 900-1800 (Harvard University Press, Cambridge (Mass), 1999)

Mote, Frederick W and Denis Twitchett (eds) The Cambridge History of China Volume 7: The Ming Dynasty, 1368-1644 Part One (Cambridge University Press, Cambridge, 1988)

Myers, Ramon H and Mark R Peattie (eds) The Japanese Colonial Empire, 1895-1945 (Princeton University Press, Princeton, 1984)

Osterhammel, Jürgen (trans Shelley L Frisch) Colonialism: A Theoretical Overview (Markus Wiener Publishers, Princeton, 1997)

Perdue, Peter C China Marches West: The Qing Conquest of Central Eurasia (Harvard University Press, Cambridge (Mass), 2005)

Peterson, Willard J (ed) The Cambridge History of China Volume 9: The Ch'ing Dynasty to 1800 Part One (Cambridge University Press, Cambridge, 2002)

Peterson, Willard J (ed) The Cambridge History of China Volume 9: The Ch'ing Dynasty to 1800 Part Two (Cambridge University Press, Cambridge, 2016)

Shepherd, John Robert Statecraft and Political Economy on the Taiwan Frontier, 16001800 (Stanford University Press, Stanford, 1993)

Simpson, Alfred W B A History of the Land Law (2ed, Clarendon Press, Oxford, 1986)

Takakura, Shinichiro (trans John A Harrison) The Ainu of Northern Japan (The American Philosophical Society, Philadelphia, 1960)

Takekoshi, Yosaburō (trans George Braithwaite) Japanese Rule in Formosa (Longmans, Green and Co, London, 1907) 
Teng, Emma Jinhua Taiwan's Imagined Geography: Chinese colonial travel writing and pictures, 1683-1895 (Harvard University Asia Centre, Cambridge (Mass), 2004)

The Republic of China Yearbook 2015 (Executive Yuan, Taipei, 2015)

Van Bremen, Jan and Akitoshi Shimizu (eds) Anthropology and Colonialism in Asia and Oceania (Curzon Press, Surrey, 1999)

Wang, Tay-sheng Legal Reform in Taiwan under Japanese Colonial Rule, 1895-1945: The Reception of Western Law (University of Washington Press, Seattle, 2000)

Weaver, John C The Great Land Rush and the Making of the Modern World, 1659-1900 (McGill-Queen's University Press, Montreal, 2003)

\section{Chinese}

Chan Su-chuan and Chang Su-fan 詹素娟，張素玢 Taiwan Yuanzhumin shi: Bei Taiwan pingpu zuqun shi 臺灣原住民史: 北臺灣平埔族群史 [History of Taiwan aborigines: the northern Taiwan plains aboriginal groups] (Taiwan Historica, Nantou, 2001)

Chen Bin 陳瑸 Chen Qingduangong wenxuan 陳清端公文選 [Selected writings of Chen Bin] (TWWX 116)

Chen Chiu-kun 陳秋坤 Qingdai Taiwan tuzhu diquan: guanliao, handian yu Anlishe ren de tudi bianqian 1700-1895 清代臺灣土著地權: 官僚, 漢佃與岸裡社人的土地變遷 1700-1895 (Taiwan's Aboriginal Proprietary Rights in the Ch'ing Period: Bureaucracy, Han Tenants and the Transformation of Property Rights of the Anli Tribe, 1700-1895) (2ed, Academia Sinica, Taipei, 1997)

Chen Di 陳第 Dongfanji 東番記 [Accounts of the eastern barbarians, 1603] in Shen Yourong 沈有容 Minhai zengyan 閩海贈言 [Words of praise from the Fujian sea] (TWWX 56)

Chen Guyuan 陳顧遠 Zhongguo fazhishi 中國法制史 [Legal history of China] (Zhongguo shudian, Beijing, 1988, facsimile copy of Shangwu yinshuguan, 1934) 
Cheng jia-ying 程家穎 Taiwan tudi zhidu kaocha baogaoshu 臺灣土地制度考察報告書 [A report on the Taiwan land tenure, 1914] (TWWX 184)

Deng Chuan'an 鄧傳安 Lice huichao 螆測彙鈔 [Measuring the sea with a calabash, 1830] (TWWX 9)

Ding Yuejian 丁日建 Zhi Tai bigaolu 治臺必告錄 [A collection of must-read documents on governing Taiwan, 1868] (TWWX 17)

Ding Zongluo 丁宗洛 Chen Qingduangong nianpu 陳清端公年譜 [A chronological biography of Chen Bin, 1825] (TWWX 207)

Fujii Shizue 藤井志津枝 Rizhi shiqi Taiwan zongdufu lifan zhengce 日治時期臺灣總督 府理蕃政策 [The aboriginal management policies of the Taiwan Sōtokufu during the Japanese period] (Wenyingtang, Taipei, 1997)

Fujii Shizue 藤井志津枝 Taiwan yuanzhumin shi: zhengce pian 薹灣原住民史政策篇 [History of Taiwan aborigines: the policy chapter] (Taiwan Historica, Nantou, 2001)

Huang Shujing 黄叔璥 Taihai shichalu 臺海使槎錄 [Records of a tour on duty over the Taiwan seas, cir 1722] (TWWX 4)

Huang Ying-kuei (ed) 黄應貴 (編) Taiwan tuzhu shehui wenhua yanjiu lunwenji 臺灣土 著社會文化研究論文集 [A collection of research essays on the society and culture of Taiwan's mountain aborigines] (Lianjing, Taipei, 1986)

Inō Kanori 伊能嘉矩 (trans Taiwan Historica) Taiwan wenhua zhi 臺灣文化志 [A history of Taiwan's civilisation] (Chinese trans Rev ed, Taiwan shufang, Taipei, 2011)

Ka Chih-ming 柯志明 Fantoujia: Qingdai Taiwan zuqun zhengzhi yu shufan diquan 番頭 家: 清代臺灣族群政治與熟番地權 (The Aborigine Landlord: Ethnic politics and aborigine land rights in Qing Taiwan) (Academia Sinica, Taipei, 2003) 
Kang, Peter 康培德 Taiwan yuanzhumin shi zhengce pian: He Xi Mingzheng shiqi 薹灣原 住民史政策篇: 荷西明鄭時期 [History of Taiwan aborigines: the policy chapter: the Dutch, Spanish and Zheng periods] (Taiwan Historica, Nantou, 2005)

Kawaguchi Choju 川口長孺 Taiwan Zhengshi jishi 臺灣鄭氏紀事 [Chronicles of the Zhengs of Taiwan, 1828] (TWWX 5)

Ke Peiyuan 柯培元 Gamalan zhilüe 噶瑪蘭志略 [Brief records of Gamalan, 1837] (TWWX 92)

Kondo Masami 近藤正已 (trans Lin Shi-ting) Zonglizhan yu Taiwan: Riben zhimindi de bengkui 總力戰與臺灣一日本殖民地的崩潰 [Total war and Taiwan: the collapse of the Japanese colony] (NTU, Taipei, 2014)

Lan Dingyuan 藍鼎元 Dongzheng ji 束征集 [Collection of records of the eastern expedition, 1732] (TWWX 12)

Lan Dingyuan 藍鼎元 Luzhou chuji 鹿洲初集 [First collection of Lan Dingyuan's writings] (Chinese Text Project, www.ctext.org)

Lan Dingyuan 藍鼎元 Ping Tai jilüe 平臺紀略 [Brief accounts of the pacification of Taiwan, 1723] (TWWX 14)

Li Ju-ho and Chuang Chin-Teh (eds) 李汝和, 莊金德(編) Taiwansheng tongzhi 臺灣省通 志 [A comprehensive history of Taiwan Province] (Taiwansheng wenxian weiyuanhui, Taizhong, 1972) Vol 10

Li Wen-liang 李文良 Qingdai nan Taiwan de yiken yu Kejia shehui (1680-1790) 清代南 臺灣的移墾與客家社會 [Land reclamation and Hakka communities in southern Taiwan during the Qing Dynasty] (NTU Press, Taipei, 2011),

Lian Heng 連横 Taiwan tongshi 㗌灣通史 [A comprehensive history of Taiwan, 1918] (TWWX 128) 
Liang Chih-hui and Chung Yu-lan 梁志輝, 種幼蘭 Taiwan yuanzhumin shi: Zhong Taiwan pingpu zuqun shi 臺灣原住民史：中臺灣平埔族群史 [History of Taiwan aborigines: the central Taiwan plains aboriginal groups] (Taiwan Historica, Nantou, 2001)

Linshi Taiwan Jiuguan Diaochahui 臨時薹灣舊慣調查會 Taiwan sifa 㗌灣私法 [Private law of Taiwan] (Chinese translation, Taiwansheng wenxian weiyuanhui, Taizhong, 1990, original first published in 1910)

Liu Ao 劉敖 Xun Tai tuisilu 巡薹退思錄 [Reflections on being a Circuit Intendant in Taiwan] (TWWX 21)

Liu Yi-chang 劉益昌 Taiwan yuanzhumin shi: shiqian pian 臺灣原住民史：史前篇 [History of Taiwan aborigines: prehistory] (Taiwan Historica, Nantou, 2002)

Luo Dachun 羅大春 Taiwan haifang bing kaishan riji 臺灣海防並開山日記 [A journal of maritime defence and mountain opening in Taiwan] (TWWX 308)

Pan Ying 潘英 Taiwan pingpuzu shi 臺灣平埔族史 [History of the Taiwanese plains aborigines] (Nantian, Taipei, 1996)

Pan Ying 潘英 Taiwan yuanzhu minzu de lishi yuanliu 臺灣原住民族的歷史源流 [History of the Taiwanese aboriginal groups] (Taiyuan, Taipei, 1998)

Peng Yuxin 彭雨新 Qingdai tudi kaiken shi 清代土地開鿶史 [History of land reclamation during the Qing Dynasty] (Nongye, Beijing, 1990)

Qinding pingding Taiwan jilïe 欽定平定臺灣紀略 [Imperially approved accounts of pacifying Taiwan] (TWWX 102)

Ruan Minxi 阮旻錫 Haishang jianwenlu 海上見聞錄 [Things seen and heard over the seas] (TWWX 24)

Sheng Ch'ing-I, Wang Shi-lang and Gao Shu-fan 盛清沂, 王詩琅, 高樹藩 Taiwan shi 臺 灣史 [History of Taiwan] (Taiwansheng wenxian weiyuanhui, Taizhong, 1977) 
Shi Lang 施琅 Jinghai jishi 靖海紀事 [Records of pacifying the seas] (TWWX 13)

Shijing 詩經 [Book of Songs] (Chinese Text Project, www.ctext.org)

Shih Tien-fu 施添福 Qingdai Taiwan de diyu shehui: Zhuqian diqu de lishi dili yanjiu 清 代臺灣的地域社會：竹塹地區的歷史地理研究 [The local society in Qing Taiwan: a research on the historical geography of the Zhuqian area] (Xinzhuxian wenhua ju, Xinzhu, 2001)

Song Tsêng-chang 宋增璋 Taiwan fuken zhi 薹灣撫墾志 [History of aboriginal management and land reclamation in Taiwan] (2ed, Taiwansheng wenxian weiyuanhui, Taizhong, 1997)

Tai Yen-hui 戴炎輝 Qingdai Taiwan zhi xiangzhi 清代臺灣之鄉治 [The administration at the town and village levels in Qing Taiwan] (Lianjing, Taipei, 1979)

Taiwan Guanxi Yanjiuhui 臺灣慣習研究會 Taiwan guanxi jishi 臺灣慣習記事 [Records of customs of Taiwan] (Chinese translation, Taiwansheng wenxian weiyuanhui, Taizhong, 1984)

Tang Qiyu 唐啟宇 Lidai tunken yanjiu 歷代屯墾研究 [A research on land reclamation through tuntian in the various dynasties] (Zhengzhong, Shanghai, 1947)

Tang Qiyu 唐啟宇 Zhongguo de kenzhi 中國的墾殖 [Land reclamation and colonisation in China] (2ed, Yongxiang, Shanghai, 1952)

Ts'ao Yung-ho 曹永和 Taiwan zaoqi lishi yanjiu 薹灣早期歷史研究 [A research on the early history of Taiwan] (Lianjing, Taipei, 1979)

Wang Dayuan 汪大淵 Daoyi zhilüe 島夷志略 [Brief accounts of the island barbarians, 1349] (in TWWX 119)

Wang Tay-sheng 王泰升 Taiwan falüshi gailun 薹灣法律史概論 [Introduction to the history of laws of Taiwan] (4ed, Yuanzhao, Taipei, 2012) 
Wang Wenjia 王文甲 Zhongguo tudi zhidushi 中國土地制度史 [History of Chinese land tenure] (Zhongzheng, Taipei, 1956)

Wen Chen-hua 溫振華 Taiwan yuanzhumin shi zhengce pian: Qingzhi shiqi 臺灣原住民 史政策篇: 清治時期 [History of Taiwan aborigines: the policy chapter: the Qing period] (Taiwan Historical, Nantou, 2007)

Wen Ji 溫吉 Taiwan fanzheng zhi 臺灣番政志 [A history of aboriginal management in Taiwan] (translated and adapted from Inō Kanori Taiwan Bansei Shi, Taiwansheng wenxian weiyuanhui, Taipei, 1957)

Xiao Yishan 蕭一山 Qingdai tongshi 清代通史 [Comprehensive history of the Qing Dynasty] (Shangwu, Taipei, 1963)

Xunzi 苟子 [The works of Xunzi] (Chinese Text Project, www.ctext.org)

Yang Jingfan et al (eds) 楊景凡等(編) Zhongguo falü sixiangshi jianbian 中國法律思想 史簡編 [A brief history of Chinese legal thoughts] (Guangxi shifan daxue, Guilin, 1988)

Yang Jun 楊軍 Qingdai Xinjiang diqu falü zhidu jiqi bianqian yanjiu 清代新疆地區法律 制度及其變遷研究 [A research on the legal system and its evolution in Qing Xinjiang] (Minzu, Beijing, 2012)

Yang Yan-jie 楊彥傑 Heju shidai Taiwan shi 荷據時代臺灣史 [The history of Taiwan under Dutch occupation] (Lianjing, Taipei, 2000)

Yang Yifan and Terada Hiroaki (eds) 楊一凡，寺田浩明(編) Zhongguofazhishi kaozheng 中國法制史考證第四卷丙篇 [Research on Chinese legal history Volume 4 Part 3] (Zhongguo shehui kexueyuan, Beijing, 2003)

Yang Ying 楊英 Congzheng shilu 從征實錄 [Veritable records of Zheng Chenggong's expeditions] (TWWX 32) 
Yao Ying 姚瑩 Dongcha jilüe 東槎紀略 [Records of my appointment to the east, 1829] (TWWX 7)

Yen Ai-ching and Yang Guo-zhu 顔愛靜, 楊國柱 Yuanzhu minzu tudi zhidu yu jingji fazhan 原住民族土地制度與經濟發展 [Land tenure and economic development of the aborigine groups] (Daoxiang, Taipei, 2004)

Yin Zhang-yi 尹章義 Taiwan kaifashi yanjiu 薹灣開發史研究 [Research on the history of land reclamation in Taiwan] (Lianjing, Taipei, 1989)

Yu Yonghe 郁永河 Bihai jiyou 裨海紀游 [Small sea travelogue, 1697] (TWWX 44)

Zhang Jinfan 張晉藩 Qingchao fazhishi 清朝法制史 [Legal history of the Qing Dynasty] (Zhonghua shuju, Beijing, 1998)

Zhang Junyue 張君約 Lidai tuntian kao 歷代屯田考 [Study of tuntian in the various dynasties] (Shangwu, Beijing, 1939)

Zhao Gang and Chen Zhongyi 趙岡，陳鐘毅 Zhongguo tudi zhidushi 中國土地制度史 [History of Chinese land tenure] (Lianjing, Taipei, 1982)

Zhao Rugua 趙汝适 Zhufanzhi 諸番志 [Accounts of various barbarians] (TWWX 119)

\section{Journal Articles and Book Chapters}

English

Adas, Michael "Imperialism and Colonialism in Comparative Perspective" (1998) 20 International History Review 371-388

Andrade, Tonio "Pirates, Pelts, and Promises: The Sino-Dutch Colony of SeventeenthCentury Taiwan and the Aboriginal Village of Favorolang" (2005) 64 Journal of Asian Studies 295-321 
Atwell, William “The T'ai-ch'ang, T'ien-ch'i, and ch'ung-chun reigns, 1620-1644" in Frederick W Mote and Denis Twitchett (eds) The Cambridge History of China Volume 7: The Ming Dynasty, 1368-1644 Part One 585-640

Banner, Stuart "Why Terra Nullius? Anthropology and Property Law in Early Australia" (2005) 23 Law and History 95-131

Barclay, Paul D “An Historian among the Anthropologists: The Inō Kanori Revival and the Legacy of Japanese Colonial Ethnography in Taiwan" (2001) 21(2) Japanese Studies $117-136$

Blundell, David “A Century of Research: Austronesian Taiwan, 1897-1997” in David Blundell (ed) Austronesian Taiwan: Linguistics, History, Ethnology, Prehistory 3-44

Blust, Robert "The Prehistory of the Austronesia-Speaking Peoples: A View from Language" (1995) 9(4) Journal of World Prehistory 453-510

Chang Lung-Chih "From Quarantine to Colonization: Qing Debates on Territorialization of Aboriginal Taiwan in the Nineteenth Century" (2008) 15(4) Taiwanshi yanjiu 1-30

Chen, Ching-chih "Police and Community Control System in the Empire" in Ramon $\mathrm{H}$ Myers and Mark R Peattie (eds) The Japanese Colonial Empire, 1895-1945 213-239

Chen, Edward I-te "The Attempt to Integrate the Empire: Legal Perspectives" in Ramon H Myers and Mark R Peattie (eds) The Japanese Colonial Empire, 1895-1945 240-274

Crossley, Pamela Kyle "Thinking about Ethnicity in Early Modern China" (1990) 11 Late Imperial China 1-35

Dennerline, Jerry "The Shun-chih Reign" in Willard J Peterson (ed) The Cambridge History of China Volume 9 Part One 73-119

Di Cosmo, Nicola "Qing Colonial Administration in Inner Asia" (1998) 20 International History Review 287-309 
Di Cosmo, Nicola “The Extension of Ch'ing Rule over Mongolia, Sinkiang, and Tibet, 1636-1800" in Willard J Peterson (ed) The Cambridge History of China Volume 9 Part Two 111-145

Elliott, Mark C "Review of Pei Huang Reorienting the Manchus: A Study of Sinicization" (2011) 54 Journal of the Economic and Social History of the Orient 584-588

Eskildsen, Robert "Taiwan: A Periphery in Search of a Narrative" (2005) 64 Journal of Asian Studies 281-294

Fairbank, John K "The Creation of the Treaty System" in John K Fairbank (ed) The Cambridge History of China Volume 10 213-263

Fairbank, J K and S Y Teng "On the Types and Uses of Ch'ing Documents" (1940) 5 Harvard Journal of Asiatic Studies 1-71

Fiskesjö, Magnus "On the 'Raw' and the 'Cooked” Barbarians of Imperial China” (1999) 1 Inner Asia 139-168

Fletcher, Joseph "Ch'ing Inner Asia c. 1800” in John K Fairbank (ed) The Cambridge History of China Volume 10 35-106

Fletcher, Joseph "Sino-Russian Relations, 1800-1862" in John K Fairbank (ed) The Cambridge History of China Volume 10 318-350

Fletcher, Joseph "The Heyday of the Ch'ing Order in Mongolia, Sinkiang and Tibet" in John K Fairbank (ed) The Cambridge History of China Volume 10 351-408

Gordon, Leonard “Japan's Abortive Colonial Venture in Taiwan, 1874” (1965) 37(2) Journal of Modern History 171-185

Grajdanzev, AJ "Formosa (Taiwan) under Japanese Rule” (1942) 15 Pacific Affairs 311 324

Guy, R Kent "Who were the Manchus? A Review Essay" (2002) 61(1) Journal of Asian Studies 151-164 
Heuschert, Dorothea "Legal Pluralism in the Qing Empire: Manchu Legislation for the Mongols" (1998) 20 International History Review 310-324

Hirakawa, Sukehiro "Japan's Turn to the West" (trans Bob Tadash Wakabayashi) in Marius B Jansen (ed) The Cambridge History of Japan Volume 5 432-498

Ho, Ping-ti 'In Defence of Sinicization: A Rebuttal of Evelyn Rawski's 'Reenvisioning the Qing”" (1998) 57 Journal of Asian Studies 123-155

Ho, Samuel Pao-San “Colonialism and Development: Korea, Taiwan and Kwantung” in Ramon H Myers and Mark R Peattie (eds) The Japanese Colonial Empire, 1895-1945 347398

Hoang, Peter "Law of Land Tenure in China: A Practical Treatise on Legal Ownership" (1922-1924) 1 China L Rev 90-96 (Part 1); 232-244 (Part 2)

Hsu, Wen-Hsiung "From Aboriginal Island to Chinese Frontier: The development of Taiwan before 1683" in Ronald G Knapp (ed) China's Island Frontier: studies in the historical geography of Taiwan 3-29

Jansen, Marius B "Introduction” in Marius B Jansen (ed) The Cambridge History of Japan Volume 5 1-49

Jansen, Marius B “Japanese Imperialism: Late Meiji Perspectives” in Ramon H Myers and Mark R Peattie (eds) The Japanese Colonial Empire, 1895-1945 61-79

Jones, Susan Mann and Philip A Kuhn "Dynastic Decline and the Roots of Rebellion" in John K Fairbank (ed) The Cambridge History of China Volume 10 107-162

Kroker, Edward "The Concept of Property in Chinese Customary Law" (1959) Ser 3 Vol 7 Transactions of the Asiatic Society of Japan 123-146

Kublin, Hyman "The Evolution of Japanese Colonialism" (1959) 2 Comparative Studies in Society and History 67-84 
Lamley, Harry J "Subethnic Rivalry in the Ch'ing Period" in Emily Martin Ahern and Hill Gates (eds) The Anthropology of Taiwanese Society (Standard University Press, California, 1981) $282-318$

Lamley, Harry J "Taiwan under Japanese rule, 1895-1945: the vicissitudes of colonialism" in Murray A Rubinstein (ed) Taiwan: A New History (Revised ed, Routledge, New York, 2015) 201-260

Lewis, M Paul Lewis, Gary F Simons and Charles D Fenning (eds) "Ethnologue: Languages of Taiwan", stand alone report in the series of Ethnologue: Languages of the World (18 ${ }^{\text {th }}$ ed, SIL International, Dallas, Texas, 2015)

Li, Gertraude Roth "State Building before 1644" in Willard J Peterson (ed) The Cambridge History of China Volume 9 Part One 9-72

Li, Paul Jen-Kuei "Formosan Languages: The State of the Art" in David Blundell (ed) Austronesian Taiwan: Linguistics, History, Ethnology, Prehistory 47-70

Norihito Mizuno "Qing China's Reaction to the 1874 Japanese Expedition to the Taiwan Aboriginal Territories" (2009) 16 Sino-Japanese Studies 99-125

Okada, Mitsuharu Vincent “The Plight of Ainu, Indigenous People of Japan” (2012) 1(1) Journal of Indigenous Social Development 1-14

Pasternak, Shiri “Jurisdiction and Settler Colonialism: Where Do Laws Meet?" (2014) 29 Canadian Journal of Law and Society 145-161

Peattie, Mark R "Introduction" in Ramon H Myers and Mark R Peattie (eds) The Japanese Colonial Empire, 1895-1945 3-52

Peattie, Mark R “Japanese Attitudes toward Colonialism, 1895-1945” in Ramon H Myers and Mark R Peattie (eds) The Japanese Colonial Empire, 1895-1945 80-127

Perdue, Peter C "Comparing Empires: Manchu Colonialism" (1998) 20 International History Review 255-262 
Pyle, Kenneth B "Meiji Conservatism" in Marius B Jansen (ed) The Cambridge History of Japan Volume 5 674-720

Rawski, Evelyn S "Reenvisioning the Qing: The Significance of the Qing Period in Chinese History” (1996) 55 Journal of Asian Studies 829-850

Rowe, William T "Social Stability and Social Change" in Willard J Peterson (ed) The Cambridge History of China Volume 9 Part One 473-562

Secher, Ulla “The Meaning of Radical Title: The Pre-Mabo Authorities Explained” (2005) 11 Australia Property Law Journal 179-208 (I) \& 209-243 (II)

Shepherd, John Robert "Taiwan Prefecture in the Eighteenth Century" in Willard J Peterson (ed) The Cambridge History of China Volume 9 Part Two 77-110

Shimizu, Akitoshi "Colonialism and the Development of Modern Anthropology" in Jan van Bremen and Akitoshi Shimizu (eds) Anthropology and Colonialism in Asia and Oceania 115-171

Spence, Jonathan D “The K'ang-hsi Reign” in Willard J Peterson (ed) The Cambridge History of China Volume 9 Part One 120-182

Sutton, Donald S "Violence and Ethnicity on a Qing Colonial Frontier: Customary and Statutory Law in the Eighteenth-Century Miao Pale" (2003) 37 Modern Asian Studies 4180

Struve, Lynn A "The Southern Ming, 1644-1662" in Frederick W Mote and Denis Twitchett (eds) The Cambridge History of China Volume 7: The Ming Dynasty, 1368-1644 Part One 641-725

Tavares, Antonio C "The Japanese Colonial State and the Dissolution of the Late Imperial Frontier Economy in Taiwan, 1886-1909” (2005) 64 Journal of Asian Studies 361-385

Thompson, Laurence G "The Earliest Chinese Eyewitness Accounts of the Formosan Aborigines" (1964) 23 Monumenta Serica 163-204 
Tryon, Darrell "Proto-Austronesian and the Major Austronesian Subgroups" in Bellwood, Peter, James J Fox and Darrell Tryon (eds) The Austronesians: Historical and Comparative Perspective (ANU E Press, Canberra, 2006) 19-41

Tsu, Timothy Y "Japanese Colonialism and the Investigation of Taiwanese 'Old Customs"” in Jan van Bremen and Akitoshi Shimizu (eds) Anthropology and Colonialism in Asia and Oceania 197-218

Wang, I-shou "Cultural Contact and the Migration of Taiwan's Aborigines: A historical perspective" in Ronald G Knapp (ed) China's Island Frontier: studies in the historical geography of Taiwan 31-54

Yang, Ming-tu “Going Back into a Future of Simplicity: Taiwan Aborigines' Sustainable Utilization of Natural Resources" in Chia-ju Chang and Scott Slovic (eds) Ecocriticism in Taiwan: Identity, Environment, and the Arts (Lexington, London, 2016) 3-15

Yao, Jen-To "The Japanese Colonial State and Its Form of Knowledge in Taiwan" in Liao Ping-hui and David Der-Wei Wang (eds) 37-61

Ye, Ruiping "Colonisation without Exploitation: The Qing Policies in Taiwan during the High Qing Period (1684-1795)" (2013) 6 (1\&2) Journal of Australasian Law Teachers Association 71-80

Ye, Ruiping "User Rights or Ownership: The Nature of Land Rights in Imperial China Using Taiwan during the Qing Period as a Case Study" (2014) 20 New Zealand Association for Comparative Law Yearbook 169-198

Zelin, Madeline "The Yung-cheng Reign" in Willard J Peterson (ed) The Cambridge History of China Volume 9 Part One 183-229

\section{Chinese}

Azuma Yoshio 東嘉生“Qingdai Taiwan zhi tudi suoyou xingtai”清代薹灣之土地所有形

態 [Land owning system in Qing Taiwan] in Taiwan jingjishi chuji 臺灣經濟史初集 [A 
first collection of the economic history of Taiwan] (Taiwan yanjiu congkan 25, Taiwan yinhang, Taipei, 1954）86-102

Chan Su-Chuan 詹素娟 “Taiwan pingpuzu de shenfen rending yu bianqian (1895-1960) yi hukou zhidu yu guoshi diaocha wei zhongxin” 臺灣平埔族的身分認定與變遷 (18951960) - 以户口制度與國勢調查的“種族”分類為中心 [The ascertainment and evolution of the plains aborigines' identity: from the perspective of the household registration system and census] (2005) 12(2) Taiwanshi yanjiu 121-166

Chang Chi-hsiung 張啟雄 “Dongxi guoji zhixu yuanli de chayi: 'zongfan tixi' dui 'zhimin tixi””東西國際秩序原理的差異 - “宗藩體系”對“殖民體系” ““A Comparison of Eastern and Western Principles of International Order: Suzerainty vs Colonization") (2003) 79 Zhongyang yanjiuyuan jindaishi yanjiusuo jikan 47-86

Chen Chiu-kun 陳秋坤 “Shijiu shiji chuqi tuzhu diquan wailiu wenti - yi Anlishe de tudi jingying weili” 十九世紀初期土著地權外流問題一以岸裡社的土地經營為例 [The aborigines' land loss in the early $19^{\text {th }}$ century - a case study on the land management of the Anli village] in Chen Chiu-kun and Hsu Hsueh-chi (eds) 陳秋坤, 許雪姬（編）Taiwan lishi shang de tudi wenti 臺灣歷史上的土地問題 [Land issues in historical Taiwan] (Academia Sinica, Taipei, 1992) 29-56

Chen Zhe-san 陳哲三 “Qingdai Nantou xianjing de shuizhen kaizao guanfu yu minjian suo banyan de jiaose” 清代南投縣境的水圳開数官府與民間所扮演的角色 [The roles of the government and the society in opening water channels in Nantou County during the Qing Dynasty] (2007) 15 Fengjia renwen shehui xuebao 105-141

Chen Zhe-san 陳哲三 “'Shuishalian’ jiqi xiangguan wenti zhi yanjiu” 水沙連”及其相關 問題之研究 [A research on Shuishalian and related issues] (1998) 49(2) Taiwan Wen Hsien 35-57 
Chuang Chi-fa 莊吉發 “Qingdai Taiwan tudi kaifa yu zuqun chongtu” 清代臺灣土地開 發與族群衝突 [Land reclamation and ethnic conflicts in Qing Taiwan] (2000) 36 Taiwan shiji 3-31

Chuang Chin-Teh 莊金德 “Qingchu yanjin yanhai renmin toudu lai Tai shimo” 清初嚴禁 沿海人民偷渡來㗌始末 [An Account of the prohibition of migration from coastal China to Taiwan in the early Qing period] (1964) 15(3)\&(4) Taiwan Wen Hsien 1-20 (Part 1), 40-62 (Part 2)

Chuang Chin-Teh 莊金德 “Qingdai chuqi Taiwan tudi kaifa daoyan”清代初期臺灣土地 開發導言 [An introduction to land reclamation in Taiwan during the early Qing period] (1971) 15\&16 Taipei Wen Hsien 166-172

Chuang Sung-lin 莊松林 “Helan zhi Taiwan Tongzhi”荷蘭之臺灣統治 (“Dutch Administration in Formosa") (1959) 10(3) Taiwan Wen Hsien 1-26

Horng Goang-jih 洪廣冀 “Linxue, ziben zhuyi yu bianqu tongzhi: Rizhi shiqi linye diaocha yu zhengli shiye de zai sikao”林學，資本主義與邊區統治：日治時期林野調查與整理 事業的再思考 [Modern forestry, capitalism and frontier management: a reconsideration of the investigation and arrangement of the forest and unreclaimed land in Taiwan during the Japanese period] (2004) 11(2) Taiwanshi yanjiu 77-144

Huang Fu-san 黄富三 “Anli she yu Hanren hezuo kaifa Qingdai Taiwan zhongbu de lishi yuanyuan” 岸里社與漢人合作開發㗌灣中部的歷史淵源 [The history of the cooperation between the Anli villages and Han settlers to reclaim central Taiwan during the Qing Dynasty] (1998) 16(2) Hanxue yanjiu 61-78

Huang Fu-San 黄富三 “Qingdai Taiwan yimin de gengdi qude wenti jiqi dui tuzhu de yingxiang”清代臺灣移民的耕地取得問題及其對土著的影響 [The methods of acquiring land by migrants in Qing Taiwan and the effects on the aborigines] (1981) 11 Shih-huo 19-36 \& 72-92 
Huang Huan-yao 黄煥堯 “Qingji Taiwan fanhuan shijian zhi benzhi tantao” 清季臺灣番 患事件之本質探討 [A discussion on the nature of aboriginal attacks in Qing Taiwan] (1987) 79 Taipei Wen Hsien 129-206

Huang Huan-yao 黄煥堯 “Qingling shiqi Taiwan de fanhuan fangzhi” 清領時期㗌灣的 番患防治 [The prevention and management of aboriginal attacks in Qing Taiwan] (1988) 32/33 Gaoshi wenxian 21-105

Huang Ying-kuei 黄應貴“Taiwan tuzhuzu de liangzhong shehui leixing jiqi yiyi”臺灣土 著族的雨種社會類型及其意義 [The two types of Taiwan mountain aboriginal societies and their significance] in Huang Ying-kuei (ed) Taiwan tuzhu shehui wenhua yanjiu lunwenji 3-43

Hui Tsun 惠邨 “Qingdai Taiwan zhi zufu” 清代臺灣之租賦 [Types of rents in Qing Taiwan] [1959] 10(2) Taiwan Wen Hsien 91-147

Ji Yunfei 季雲飛 “Tongzhi jiaxu qian Qing zhengfu Taiwan yimin zhengce zhi tanxi” 同 治甲戌前清政府㗌灣移民政策之探析 [An analysis of the Qing government's policies concerning migration to Taiwan before 1874] [1998] 5 Xueshujie 64-68

Ka Chih-ming 柯志明 “Fanxiaozu de xingcheng yu yanbian: Anli xinshe diyu shefan kouliangtian de zudian anpai” 番小租的形成與演變：岸裡新社地域社番口糧田的租佃 安排 ("Formation and Transformation of Aborigine Small-rent Land Tenure: Land Tenancy of Tribesman's Ration Plot in Anli New Territory") (2008) 15(3) Taiwanshi yanjiu 57-137

Li Li and Zhao Guohui 李理, 趙國輝 “Li Xiande yu Riben diyici qin Tai” [Le Gendre and Japan's first invasion of Taiwan] [2007] 3 Jindaishi yanjiu 100-116

Li, Paul Jen-kuei 李壬癸“Taiwan pingpuzu de zhonglei jiqi xianghu guanxi” 臺灣平埔族 的種類及其相互關係 [The classification of Taiwanese plains aborigines and their interrelationships] in Zhang Yan-xian, Li Xiao-feng and Dai Bao-cun (eds) 張炎憲，李䈗峯， 
戴寶村(編) Taiwanshi lunwen jingxuan 臺灣史論文精選 [Selected essays on Taiwan history] (Yushan, Taipei, 1996) 43-68

Li Wen-liang 李文良 “Linye zhengli shiye yu dong Taiwan tudi suoyouquan zhi chengli xingtai, 1910-1925” 林野整理事業與東㗌灣土地所有權之成立形態, 1910-1925 [The forestland investigation project and methods of establishing land ownership in eastern Taiwan, 1910-1925] (1997) 2 Dong Taiwan yanjiu 169-195

Lin Chiou-mien 林秋綿 “Taiwan geshiqi tudi zhengce yanbian jiqi yingxiang zhi tantao" 臺灣各時期土地政策演變及其影響之探討 [The evolution and influence of aboriginal land policies of different periods in Taiwan] (2001) 2 Taiwan tudi yanjiu 23-40

Lin Wen-kai 林文凱“'Ye ping qi guan’? Qingdai Taiwan tudi yezhuquan yu susong wenhua de fenxi” “業憑契管”? 清代臺灣土地業主權與訴訟文化的分析 [“Deed determines ye"? An analysis on yezhu rights and litigation culture in Qing Taiwan] (2011) 18:2 Taiwanshi yanjiu 1-52

Lin Yu-ju 林玉茹“You yulin tuce kan Qingmo houshan de qingfu shiye yu diquan fenpei xingtai” 由魚鱗圖冊看清末後山的清賦事業與地權分配形態 [The land survey project and the pattern of land rights distribution in eastern Taiwan during the late Qing period as seen from the "fish-scale" land register] (1997) 2 Dong Taiwan yanjiu 131-168

Lin Yu-ju and Wei Dong 林玉茹，畏冬 “Lin Shuangwen shijian qian de Taiwan bianqu tuxiang: yi Qianlong 49 nian Taiwan fanjie zixiantu wei zhongxin”林爽文事件前的薹灣 邊區圖像：以乾隆 49 年臺灣番界紫綫圖鳸中心 [Frontier areas in Taiwan before the Lin Shuangwen uprising: an investigation centering on the 1784 purple-line aboriginal boundaries] (2012) 19(3) Taiwanshi yanjiu 47-94

Mio Kishimoto 岸本美緒 “Mingqing shidai de zhaojia huisu wenti” 明清時代的“找價回 贖”問題 [The issue of price top-up and redemption during the Ming and Qing dynasties] in Yang Yifan and Terada Hiroaki (eds) 423-459 
Sheng Ch'ing-I 盛清沂 “Qingdai Taiwan Tong-Guang zhiji kaishan fufan shishi biannian” 清代臺灣同光之際開山撫番史事編年 [Chronicles of the “opening the mountains and subjugating the aborigines" campaigns during the Tongzhi and Guangxu years] (1979) 30(3) Taiwan Wen Hsien 1-26

Sheng Ch'ing-I 盛清沂 “Xinzhu, Taoyuan, Miaoli sanxian diqu kaifashi” 新竹、桃園、 苗栗三縣地區開發史 [The history of reclamation in the three counties of Xinzhu, Taoyuan and Miaoli] (1980) 31(4) \& (1981) 32(1) Taiwan Wen Hsien 154-176 (Part I); 136-157 (Part II)

Shih Tien-fu 施添福 “Qingdai Taiwan “fanli bu’an gengzuo’ de yuanyou”清代臺灣“番黎 不諳耕作”的緣由 [The reasons behind the aborigines being “unskilful at farming”] (1990) 69 Bulletin of the Institute of Ethnology Academia Sinica 67-92

Song Tsêng-chang 宋增璋 “Qingdai Taiwan fuken cuoshi zhi chengxiao jiqi yingxiang” 清代臺灣撫䛻措施之成效及其影響 [The consequences and influences of the Qing's land and aboriginal policies in Taiwan] (1979) 30(1) Taiwan Wen Hsien 142-156

Tai Yen-hui 戴炎輝 “Qingdai Taiwan xiangzhuang zhi shehui de kaocha” 清代臺灣鄉莊 之社會的考察 [An investigation of the local society in Qing Taiwan] (1963) Taiwan yinhang jikan 198-228

Tai Yen-hui 戴炎輝 “Qingdai Taiwan zhi daxiaozu ye” 清代薹灣之大小租業 [The large rent and small rent rights in Qing Taiwan] 1963(4) Taipei Wen Hsien 1-47

Terada Hiroaki 寺田浩明 “Tianmian tiandi guanli de falü xing: yi gainianxing de fenxi weizhu” 田面田底慣例的法律性一以概念性的分析為主 [The legal nature of the customary practice of top-soil and sub-soil rights: a conceptual analysis] in Yang Yifan and Terada Hiroaki (eds) 344-422

Wei Hue-lin 衛惠林 “Taiwan tuzhu shehui de buluo zuzhi yu quanwei zhidu” 薹灣土著 社會的部落組織與權威制度 [The tribal organisation and power system in the Taiwanese 
mountain aboriginal societies] in Huang Ying-kuei (ed) Taiwan tuzhu shehui wenhua уапjiu lunwenji 111-140

Wu Qi-hao 吴奇浩 “You Dadushe zai tan Qingdai Taiwan zhi shufan diquan” 由大肚社再 探清代薹灣之熟番地權 [A discussion of the acculturated aborigines' land rights through a case study on the Dadu village] (2003) 20 Taiwan shiliao yanjiu 34-67

Wu Tsong-min 吴聰敏 “Helan tongzhi shiqi zhi pushe zhidu” 荷蘭統治時期之贌社制度 [The pushe system during the Dutch period] (2008) 15(1) Taiwanshi yanjiu 1-29

Wu Tsong-min 吴聰敏 “Pushe zhidu zhi yanbian jiqi yingxiang, 1644-1737”贌社制度之 演變及其影響, 1644-1737 [The evolution and consequence of the pushe system, 16441737] (2009) 16(3) Taiwanshi yanjiu 1-38

Wu Wen-hsing 吳文星 “Jingdu diguo daxue yu Taiwan jiuguan diaocha” 京都帝國大學 與臺灣舊慣調查 [Kyoto Imperial University and the investigation of old customs in Taiwan] (2007) 1 Shida Taiwanshi xuebao 29-49

\section{Theses}

\section{English}

Caruthers, Sandra "Charles Le Gendre, American Diplomacy, and Expansionism in Meiji Japan, 1868-1893 (PhD diss, University of Colorado, 1966)

Chang Lung-Chih "From Island Frontier to Imperial Colony: Qing and Japanese Sovereignty Debates and Territorial Projects in Taiwan, 1874-1906" (PhD diss, Harvard University, 2003)

Hung Chien-Chao "Taiwan under the Cheng Family: Sinicization after Dutch Rule" (PhD diss, Georgetown University, 1981)

Sugimoto, Tomonori “The Yellow Man's Burden: The Politics of Settler Colonialism in Hokkaidō and Taiwan” (MA thesis, University of California, San Diego, 2013) 
Tian Huan "Governing Imperial Border: Insights from the Study of the Implementation of Law in Qing Xinjiang” (PhD diss, Columbia University, 2012).

\section{Chinese}

Li Wen-liang 李文良 “Diguo de shanlin: Rizhi shiqi Taiwan shanlin zhengceshi yanjiu” 帝國的山林-- 日治時期臺灣山林政策史研究 [The Empire's forest: a research on the history of Taiwan forest policies during the Japanese period] (PhD diss, NTU, 2001)

Li Zhi-yin 李志殷 “Taiwan tudi dengji zhidu bianqian zhi yanjiu” 臺灣土地登記制度變 遷之研究 [A research on the evolution of Taiwan land registration system] (LLM diss, Taiwan National Chengchi University, 2010)

Lin Qiong-hua 林瓊華 “Taiwan yuanzhumin tudi chanquan zhi yanbian, 1624-1945” [The evolution of Taiwan aborigines' land rights, 1624-1945] (PhD diss, Soochow University, 1997)

Lin Shu-Ya 林淑雅“Jie/chonggou Taiwan yuanzhu minzu tudi zhengce”解/重構臺灣原 住民族土地政策 (“De-/Reconstructing the Land Policies for Indigenous Peoples in Taiwan”) (PhD diss, NTU, 2007)

Zhou Mao-chun 周茂春 “Rizhi chuqi Taiwan tudi diaocha zhi yanjiu (1898-1905)”日治 初期臺灣土地調查之研究 [A research on the land survey during the early Japanese period, 1898-1905] (Masters thesis, National Taiwan Normal University, 2011)

\section{$V$ Others}

Council of Indigenous Peoples website www.apc.gov.tw

Ramzy, Austin “Taiwan's President Apologizes to Aborigines for Centuries of Injustice” New York Times (Online ed, New York, 1 August 2016), Sinosphere

Taiwan History and Culture in Time and Space, Academia Sinica www.thcts.sinica.edu.tw 